\title{
Unraveling one of the 'Big Five': update of the taxonomy of Triphoridae (Gastropoda, Triphoroidea) from Brazil
}

\author{
Maurício Romulo FERNANDES ${ }^{1, *} \&$ Alexandre Dias PIMENTA ${ }^{2}$ \\ ${ }^{1}$ Departamento de Zoologia, Instituto de Biociências, Universidade Federal do Estado do Rio de \\ Janeiro, Av. Pasteur, 458, Urca, 22290-240, Rio de Janeiro, Brazil. \\ ${ }^{1,2}$ Departamento de Invertebrados, Museu Nacional, Universidade Federal do Rio de Janeiro, Quinta \\ da Boa Vista, São Cristóvão, 20940-040, Rio de Janeiro, Brazil. \\ *Corresponding author: mauriciofernandes14@hotmail.com \\ ${ }^{2}$ Email: alexpim@mn.ufrj.br \\ ${ }^{1}$ urn:lsid:zoobank.org:author:3B8B864F-3300-45B2-8D1F-61F282F83CDE \\ ${ }^{2}$ urn:lsid:zoobank.org:author:2A42AE1F-6AF8-4AB3-975C-D3CE4D678F22
}

\begin{abstract}
The present study aims to fulfill the gap of taxonomic knowledge on Triphoridae from Brazil. We describe five new species (Isotriphora uncia sp. nov., Isotriphora leo sp. nov., Monophorus verecundus sp. nov., Sagenotriphora albocaput sp. nov., Similiphora lucida sp. nov.), report five species previously known only from the Caribbean and related areas (Cheirodonta dupliniana (Olsson, 1916), Eutriphora auffenbergi Rolán \& Lee, 2008, Isotriphora tricingulata Rolán \& Fernández-Garcés, 2015, Marshallora ostenta Rolán \& Fernández-Garcés, 2008, Monophorus caracca (Dall, 1927) comb. nov.) and describe six morphotypes at the generic level (Isotriphora sp. 1, Marshallora sp. 1, Nanaphora sp. 1, Sagenotriphora sp. 1, Sagenotriphora sp. 2, Similiphora sp. 1). Remarks are made to some species previously recorded from Brazil, including the invalidation of records, problems of generic allocation and geographical range extensions. Maps of the geographical distribution are provided for the 65 currently recognized species of Triphoridae from Brazil. Of these, 31 species are endemic to Brazil and 58 inhabit the continental shelf vs only seven from the continental slope. A distinct geographical zone occurs in southeastern Brazil. A few species occur exclusively near the mouth of the Amazon River, whereas others inhabit a local biogenic reef, possibly serving as a biogeographical corridor that connects western Atlantic populations. Species of Isotriphora from Brazil are particularly common around oceanic islands, probably due to adopting intracapsular metamorphosis, which may have evolved in more than one evolutionary event.
\end{abstract}

Keywords. Mollusca, marine snails, biodiversity, shell, West Atlantic.

Fernandes M.R. \& Pimenta A.D. 2020. Unraveling one of the 'Big Five': update of the taxonomy of Triphoridae (Gastropoda, Triphoroidea) from Brazil. European Journal of Taxonomy 665: 1-170.

https://doi.org/10.5852/ejt.2020.665 


\section{Introduction}

Triphoridae Gray, 1847 is a family of marine gastropods, mainly distributed over shallow waters of tropical and temperate regions (Marshall 1983), with some species also occurring in the deep sea (Fernandes \& Pimenta 2017a). Triphorids belong to the superfamily Triphoroidea Gray,1847, which also includes Cerithiopsidae Adams \& Adams, 1853 and Newtoniellidae Korobkov, 1955. The feeding mode of triphorids follows that of the superfamily, i.e., they are mainly sponge feeders (Wells 1998). It is one of the best examples of problematic groups in molluscan taxonomy, with hundreds of synonyms, nomina dubia and species with very worn type material (Bouchet \& Strong 2010).

Triphorids have a small, multi-whorled shell, usually less than $10 \mathrm{~mm}$ long in adults. They are commonly identified by their sinistral coiling, typical of the subfamily Triphorinae Gray, 1847, rather than the dextral shells of species in the other subfamily, Metaxiinae Marshall, 1977. Triphorids display a huge variation in the composition of the radula (Marshall 1983; Fernandes \& Pimenta 2019a), sometimes referred to as "rhinioglossate" because of the presence of several marginal teeth and a peculiar morphological variability of teeth and cusps. Distinctive sculpture of both embryonic and larval shell for species with a multispiral protoconch constitute another remarkable feature of this family (Marshall 1983; Fernandes \& Pimenta 2017b).

Illustrating its problematic taxonomy, only one third of triphorid types stored at the collections of the MNHN (Muséum national d'histoire naturelle, Paris, France) and the NMNH (National Museum of Natural History, Washington D.C., USA) has a protoconch in good condition (Bouchet \& Strong 2010), which hinders a proper linkage between recently sampled material and described species. On the other hand, triphorids offer a unique opportunity for anyone interested to describe new species: 2500 to 5000 species (described or not) are estimated to be present in the Indo-Pacific alone (Albano et al. 2011), which is much more than the 658 Recent species described up to now in the world (MolluscaBase 2019). Notwithstanding this, Triphoridae is regarded as one of the "Big Five" (Bouchet et al. 2002; Albano et al. 2011), representing one of the five most species-rich families of marine gastropods in the world. Despite having 42 accepted genera (MolluscaBase 2019), no phylogeny of this speciose family has been inferred after the initial efforts of Kosuge (1966) and Nützel (1998), resulting in uncertain relationships and a questionable validity of many genera. Comprehensive taxonomic revisions of triphorids are scarce, which limits our knowledge of the real richness of this group and a thorough comparison of the distribution of species at regional scales.

Triphoridae was initially cited from Brazil by Lange-de-Morretes (1949), with two species: Triphora pulchella (C.B. Adams, 1850), from Rio Grande do Norte, and the invalid record of the eastern Atlantic species Triphora perversa (Linnaeus, 1758), from Pernambuco. After six decades and several general works and catalogues that listed Triphoridae (e.g., Marcus \& Marcus 1963; Rios 1970, 1994, 2009; Absalão 1989; Leal 1991; Absalão et al. 2006; Santos et al. 2007), only Simone (2006) described one species with a type locality from Brazil. Until 2010, 13 triphorid species were known from Brazil, although most of them without appropriate illustrations or descriptions, some doubtful records, and mentioned under old generic or specific names. After 2010, a major taxonomic revision was conducted to evaluate the real diversity of Triphoridae in Brazil (Fernandes \& Pimenta 2011, 2014, 2015, 2017b, 2019a, 2019b; Fernandes et al. 2013).

The present study completes a series of works that have gradually filled the large gap of taxonomic knowledge on Triphoridae from Brazil, and aims to: (1) describe and record the remaining species of Triphoridae from Brazil; (2) add some considerations to previously recorded species; (3) provide updated maps of geographical ranges of all triphorids from Brazil; (4) discuss common patterns related to the geographical and bathymetric distribution of triphorids from Brazil. 


\section{Material and methods}

A large fraction of the material was sampled by dredgings along the Brazilian continental shelf and slope, through major scientific expeditions (Table 1) or minor projects, in addition to hand-collected specimens. Conchological procedures and terminologies were based on Fernandes \& Pimenta (2015, 2019b). Descriptions are solely based on shells from Brazil in cases of species that have already been described from other regions. Measurements given for shells in figure captions are related to their length. The term "Caribbean", between quotation marks, is employed when referring to Caribbean and adjacent areas (i.e., Gulf of Mexico and northwestern Atlantic). The Appendix contains all examined material not previously listed in any paper, in addition to new illustrations of some species. The abbreviation 'st.' stands for 'station'.

Maps of the geographical distribution were created after an extensive literature review and the analysis of several malacological collections; most references can be checked in the synonymy lists of the respective species (including Appendix). Triphorids endemic to the "Caribbean" were not included. Diagonal marks inside circles indicate samples from REVIZEE-Norte (northern Brazil), which have inaccurate data. Samplings in some countries or states (e.g., Louisiana, USA) are generalized in the maps, because some authors did not specify precise coordinates. The single 'grey' reference used is the electronic database maintained by Dr. Harry Lee (www.jaxshells.org), especially from localities in Florida (USA), owing to the considerable experience of this author with triphorids (Lee 2009). Although Brazilian records have been carefully investigated, many "Caribbean" records in the literature were provided by non-specialist researchers. Some local checklists of molluscs from the "Caribbean" might have been overlooked, thus maps are possibly incomplete. Eastern Atlantic records of Cosmotriphora melanura (C.B. Adams, 1850) were disregarded, because they may belong to another species (see Results). The distribution map of a species complex in Marshallora will be shown elsewhere (unpublished data).

The following list summarizes acronyms of scientific institutions and expeditions hereafter mentioned: (AMASSEDS) A Multidisciplinary Amazon Shelf Sediment Study, OC. Ship Columbus Iselin coll.; (BMSM) The Bailey-Matthews National Shell Museum, Sanibel, USA; (BPot) Projeto de Caracterização e Monitoramento Ambiental da Bacia Potiguar [Project of Environmental Characterization and Monitoring of Potiguar Basin], supply-boat Astro Garoupa coll.; (CHL) Harry Lee' S private collection, USA; (FLMNH) Florida Museum of Natural History, Gainesville, USA; (GEOMAR) Expedição Oceanográfica GEOMAR [Oceanographic Expedition GEOMAR], OC. Ship Almirante Saldanha coll.; (HAB) Projeto Habitats: Heterogeneidade Ambiental da Bacia de Campos [Habitats Project: Environmental Heterogeneity of Campos Basin], R/V Miss Emma McCall coll.; (IBUFRJ) Instituto de Biologia/Universidade Federal do Rio de Janeiro, Rio de Janeiro, Brazil; (INV MOL) collection of Mollusca of the Instituto de Investigaciones Marinas y Costeras - INVEMAR, Santa Marta, Colombia; (JOPS) Joint Oceanographic Projects, R/V Victor Hensen coll.; (MARSEAL) Caracterização Ambiental da Bacia de Sergipe-Alagoas [Environmental Characterization of the Sergipe-Alagoas Basin]; (MCZ) Museum of Comparative Zoology, Cambridge, USA; (MD55) French-Brazilian Expedition MD55, R/V Marion-Dufresne coll.; (MLP) Museo de La Plata (Section: 'Paleozoología de Invertebrados'), La Plata, Argentina; (MNCN) Museo Nacional de Ciencias Naturales, Madrid, Spain; (MNHN) Muséum national d'histoire naturelle, Paris, France; (MNHN-Mo) Museo Nacional de Historia Natural, Montevideo, Uruguay; (MNRJ) Museu Nacional, Universidade Federal do Rio de Janeiro, Rio de Janeiro, Brazil; (MORG) Museu Oceanográfico "Prof. Eliézer de Carvalho Rios", Rio Grande, Brazil; (MZUSP/MZSP) Museu de Zoologia da Universidade de São Paulo, São Paulo, Brazil; (PADCT) Programa de Apoio ao Desenvolvimento Tecnológico e Científico [Program of Support to the Technological and Scientific Development], OC. Ship Prof. W. Besnard coll.; (PRI) Paleontological Research Institute, Cornell University, New York, USA; (NHM) Natural History Museum, London, UK; (NMNH/USNM) National Museum of Natural History, Washington D.C., USA; (RAP-BIG) 'Rapid Assessment Protocol' of Baía da Ilha Grande; (REVIZEE) Programa de Avaliação do Potencial Sustentável de Recursos Vivos da 
Table 1 (continued on next two pages). Scientific expeditions that sampled most material listed in this study.

\begin{tabular}{|c|c|c|c|}
\hline Expedition/station & Coordinates & Depth (m) & Date \\
\hline AMASSEDS st. 3210 & $01^{\circ} 52^{\prime} 27^{\prime \prime} \mathrm{N}, 48^{\circ} 16^{\prime} 01^{\prime \prime} \mathrm{W}$ & 47 & May 1990 \\
\hline AMASSEDS st. 4134 & $02^{\circ} 21^{\prime} 12^{\prime \prime} \mathrm{N}, 48^{\circ} 29^{\prime} 54^{\prime \prime} \mathrm{W}$ & $45-50$ & Mar.1997 \\
\hline BPot 1-MR11 & $05^{\circ} 02^{\prime} \mathrm{S}, 36^{\circ} 10^{\prime} \mathrm{W}$ & 5 & - \\
\hline BPot 1-MR22 & $04^{\circ} 58^{\prime} \mathrm{S}, 36^{\circ} 15^{\prime} \mathrm{W}$ & 10 & - \\
\hline BPot 1-MR23 & $04^{\circ} 57^{\prime} \mathrm{S}, 36^{\circ} 36^{\prime} \mathrm{W}$ & 10 & - \\
\hline BPot 1-MR25 & $04^{\circ} 53^{\prime} \mathrm{S}, 36^{\circ} 46^{\prime} \mathrm{W}$ & 10 & - \\
\hline BPot 1-MR26 & $04^{\circ} 48^{\prime} \mathrm{S}, 36^{\circ} 55^{\prime} \mathrm{W}$ & 10 & - \\
\hline BPot 1-MR31 & $04^{\circ} 53^{\prime} \mathrm{S}, 36^{\circ} 10^{\prime} \mathrm{W}$ & 20 & - \\
\hline BPot 1-MR32 & $04^{\circ} 49^{\prime} 20^{\prime \prime} \mathrm{S}, 36^{\circ} 25^{\prime} 56^{\prime \prime} \mathrm{W}$ & 22 & 27 Oct. 2009 \\
\hline BPot 1-MR34 & $04^{\circ} 52^{\prime} \mathrm{S}, 36^{\circ} 39^{\prime} \mathrm{W}$ & 20 & - \\
\hline BPot 1-MR41 & $04^{\circ} 49^{\prime} 40^{\prime \prime} \mathrm{S}, 36^{\circ} 10^{\prime} 06^{\prime \prime} \mathrm{W}$ & 58 & 27 Oct. 2009 \\
\hline BPot 1-MR42 & $04^{\circ} 45^{\prime} 54^{\prime \prime} \mathrm{S}, 36^{\circ} 25^{\prime} 49^{\prime \prime} \mathrm{W}$ & 52 & 25 Oct. 2009 \\
\hline BPot 1-MR43 & $04^{\circ} 44^{\prime} \mathrm{S}, 36^{\circ} 35^{\prime} \mathrm{W}$ & 50 & - \\
\hline BPot 1-MR44 & $04^{\circ} 38^{\prime} 28^{\prime \prime} \mathrm{S}, 36^{\circ} 45^{\prime} 37^{\prime \prime} \mathrm{W}$ & 50 & 23 Oct. 2009 \\
\hline BPot 1-MR45 & $04^{\circ} 35^{\prime} 17^{\prime \prime}$ S, $36^{\circ} 55^{\prime} 03^{\prime \prime} \mathrm{W}$ & 47 & - \\
\hline BPot 2-MR22 & $04^{\circ} 58^{\prime} \mathrm{S}, 36^{\circ} 15^{\prime} \mathrm{W}$ & 10 & - \\
\hline BPot 2-MR23 & $04^{\circ} 57^{\prime} \mathrm{S}, 36^{\circ} 36^{\prime} \mathrm{W}$ & 10 & - \\
\hline BPot 2-MR32 & $04^{\circ} 49^{\prime} 20^{\prime \prime}$ S, $36^{\circ} 25^{\prime} 56^{\prime \prime} \mathrm{W}$ & 20 & - \\
\hline BPot 2-MR33 & $04^{\circ} 49^{\prime} \mathrm{S}, 36^{\circ} 36^{\prime} \mathrm{W}$ & 20 & - \\
\hline BPot 2-MR34 & $04^{\circ} 52^{\prime} \mathrm{S}, 36^{\circ} 39^{\prime} \mathrm{W}$ & 20 & - \\
\hline BPot 2-MR41 & $04^{\circ} 49^{\prime} 40^{\prime \prime} \mathrm{S}, 36^{\circ} 10^{\prime} 06^{\prime \prime} \mathrm{W}$ & 50 & - \\
\hline BPot 2-MR42 & $04^{\circ} 45^{\prime} 54^{\prime \prime} \mathrm{S}, 36^{\circ} 25^{\prime} 49^{\prime \prime} \mathrm{W}$ & 50 & - \\
\hline BPot 2-MR44 & $04^{\circ} 38^{\prime} 28^{\prime \prime} \mathrm{S}, 36^{\circ} 45^{\prime} 37^{\prime \prime} \mathrm{W}$ & 50 & - \\
\hline BPot 2-MR45 & $04^{\circ} 35^{\prime} 17^{\prime \prime}$ S, 36 $55^{\circ} 03^{\prime \prime} \mathrm{W}$ & 50 & - \\
\hline BPot MT45 & $04^{\circ} 36^{\prime} 41^{\prime \prime} \mathrm{S}, 36^{\circ} 46^{\prime} 41^{\prime \prime} \mathrm{W}$ & $157-172$ & 21 May 2011 \\
\hline GEOMAR II st. D & $00^{\circ} 28^{\prime} 06^{\prime \prime} \mathrm{S}, 47^{\circ} 57^{\prime} 42^{\prime \prime} \mathrm{W}$ & 29 & 8 Sep. 1970 \\
\hline GEOMAR II st. 99 & $02^{\circ} 38^{\prime} 30^{\prime \prime} \mathrm{N}, 48^{\circ} 55^{\prime} 00^{\prime \prime} \mathrm{W}$ & 77 & 11 Sep. 1970 \\
\hline GEOMAR II st. 124 & $03^{\circ} 32^{\prime} 12^{\prime \prime} \mathrm{N}, 48^{\circ} 59^{\prime} 48^{\prime \prime} \mathrm{W}$ & 103 & 13 Sep. 1970 \\
\hline GEOMAR III st. 181 & $04^{\circ} 46^{\prime} 00^{\prime \prime} \mathrm{N}, 50^{\circ} 46^{\prime} 30^{\prime \prime} \mathrm{W}$ & 74 & 6 May 1971 \\
\hline HAB 11-B4 & $23^{\circ} 10^{\prime} 00^{\prime \prime} \mathrm{S}, 41^{\circ} 03^{\prime} 13^{\prime \prime} \mathrm{W}$ & 107 & 21 Feb.2009 \\
\hline HAB 11-B5 & $23^{\circ} 11^{\prime} 25^{\prime \prime} \mathrm{S}, 41^{\circ} 00^{\prime} 56^{\prime \prime} \mathrm{W}$ & 106 & 21 Feb.2009 \\
\hline HAB 11-C3 & $22^{\circ} 46^{\prime} 51^{\prime \prime} \mathrm{S}, 41^{\circ} 03^{\prime} 39^{\prime \prime} \mathrm{W}$ & 77 & 22 Feb.2009 \\
\hline HAB 11-C4 & $22^{\circ} 51^{\prime} 57^{\prime \prime} \mathrm{S}, 40^{\circ} 57^{\prime} 35^{\prime \prime} \mathrm{W}$ & 92 & 22 Feb.2009 \\
\hline HAB 11-D3 & $22^{\circ} 19^{\prime} 28^{\prime \prime} \mathrm{S}, 40^{\circ} 37^{\prime} 25^{\prime \prime} \mathrm{W}$ & 75 & 15 Mar.2009 \\
\hline HAB 11-G3 & $22^{\circ} 03^{\prime} 41^{\prime \prime} \mathrm{S}, 40^{\circ} 10^{\prime} 05^{\prime \prime} \mathrm{W}$ & 75 & $25 \mathrm{Feb} .2009$ \\
\hline HAB 11-G4 & $22^{\circ} 04^{\prime} 10^{\prime \prime} \mathrm{S}, 40^{\circ} 07^{\prime} 06^{\prime \prime} \mathrm{W}$ & 91 & 25 Feb.2009 \\
\hline HAB 13-H1 & $21^{\circ} 43^{\prime} 18^{\prime \prime} \mathrm{S}, 40^{\circ} 31^{\prime} 58^{\prime \prime} \mathrm{W}$ & 26 & 9 Mar.2009 \\
\hline HAB $13-\mathrm{H} 2$ & $21^{\circ} 44^{\prime} 15^{\prime \prime} \mathrm{S}, 40^{\circ} 17^{\prime} 22^{\prime \prime} \mathrm{W}$ & 50 & 9 Mar.2009 \\
\hline HAB 13-H3 & $21^{\circ} 43^{\prime} 06^{\prime \prime} \mathrm{S}, 40^{\circ} 11^{\prime} 37^{\prime \prime} \mathrm{W}$ & 73 & 9 Mar.2009 \\
\hline HAB 13-H4 & $21^{\circ} 42^{\prime} 49^{\prime \prime} \mathrm{S}, 40^{\circ} 10^{\prime} 21^{\prime \prime} \mathrm{W}$ & 98 & 9 Mar.2009 \\
\hline HAB 13-I2 & $21^{\circ} 22^{\prime} 55^{\prime \prime} \mathrm{S}, 40^{\circ} 19^{\prime} 48^{\prime \prime} \mathrm{W}$ & 52 & 5 Mar.2009 \\
\hline HAB 13-I4 & $21^{\circ} 22^{\prime} 55^{\prime \prime} \mathrm{S}, 40^{\circ} 15^{\prime} 31^{\prime \prime} \mathrm{W}$ & 103 & 6 Mar.2009 \\
\hline HAB 16-B4 & $23^{\circ} 10^{\prime} 01^{\prime \prime} \mathrm{S}, 41^{\circ} 03^{\prime} 13^{\prime \prime} \mathrm{W}$ & 107 & 2 Jul. 2009 \\
\hline HAB 16-B5 & $23^{\circ} 12^{\prime} 04^{\prime \prime} \mathrm{S}, 40^{\circ} 59^{\prime} 42^{\prime \prime} \mathrm{W}$ & 141 & 2 Jul. 2009 \\
\hline HAB 16-C3 & $22^{\circ} 46^{\prime} 50^{\prime \prime} \mathrm{S}, 41^{\circ} 03^{\prime} 39^{\prime \prime} \mathrm{W}$ & 78 & 2 Jul. 2009 \\
\hline HAB 16-C4 & $22^{\circ} 51^{\prime} 57^{\prime \prime} \mathrm{S}, 40^{\circ} 57^{\prime} 35^{\prime \prime} \mathrm{W}$ & 90 & 3 Jul. 2009 \\
\hline HAB 16-G1 & $21^{\circ} 49^{\prime} 50^{\prime \prime} \mathrm{S}, 40^{\circ} 44^{\prime} 42^{\prime \prime} \mathrm{W}$ & 28 & 11 Jul. 2009 \\
\hline HAB 16-G3 & $22^{\circ} 03^{\prime} 41^{\prime \prime} \mathrm{S}, 40^{\circ} 10^{\prime} 05^{\prime \prime} \mathrm{W}$ & 76 & 6 Jul. 2009 \\
\hline
\end{tabular}


FERNANDES M.R. \& PIMENTA A.D., Update of Triphoridae from Brazil

Table 1 (continued). Scientific expeditions that sampled most material listed in this study.

\begin{tabular}{|c|c|c|c|}
\hline Expedition/station & Coordinates & Depth (m) & Date \\
\hline HAB 16-G4 & $22^{\circ} 03^{\prime} 34^{\prime \prime} \mathrm{S}, 40^{\circ} 07^{\prime} 06^{\prime \prime} \mathrm{W}$ & 89 & 6 Jul. 2009 \\
\hline HAB 16-H2 & $21^{\circ} 44^{\prime} 15^{\prime \prime} \mathrm{S}, 40^{\circ} 17^{\prime} 22^{\prime \prime} \mathrm{W}$ & 50 & 8 Jul. 2009 \\
\hline HAB $16-\mathrm{H} 3$ & $21^{\circ} 43^{\prime} 06^{\prime \prime} \mathrm{S}, 40^{\circ} 11^{\prime} 37^{\prime \prime} \mathrm{W}$ & 71 & 7 Jul. 2009 \\
\hline HAB 16-H4 & $21^{\circ} 42^{\prime} 50^{\prime \prime} \mathrm{S}, 40^{\circ} 10^{\prime} 21^{\prime \prime} \mathrm{W}$ & 97 & 7 Jul. 2009 \\
\hline HAB 17-I1 & $21^{\circ} 10^{\prime} 56^{\prime \prime} \mathrm{S}, 40^{\circ} 28^{\prime} 34^{\prime \prime} \mathrm{W}$ & 26 & 21 Jul. 2009 \\
\hline HAB $17-I 2$ & $21^{\circ} 22^{\prime} 54^{\prime \prime} \mathrm{S}, 40^{\circ} 19^{\prime} 51^{\prime \prime} \mathrm{W}$ & 53 & 21 Jul. 2009 \\
\hline HAB 17-I3 & $21^{\circ} 23^{\prime} 34^{\prime \prime} \mathrm{S}, 40^{\circ} 15^{\prime} 43^{\prime \prime} \mathrm{W}$ & 88 & 21 Jul. 2009 \\
\hline HAB 17-I4 & $21^{\circ} 09^{\prime} 05^{\prime \prime} \mathrm{S}, 40^{\circ} 16^{\prime} 13^{\prime \prime} \mathrm{W}$ & 103 & 21 Jul. 2009 \\
\hline JOPS st. 3235 & $18^{\circ} 00^{\prime} 00^{\prime \prime} \mathrm{S}, 38^{\circ} 12^{\prime} 06^{\prime \prime} \mathrm{W}$ & 55 & 23 Apr. 1995 \\
\hline JOPS st. 3236 & $18^{\circ} 07^{\prime} 24^{\prime \prime} \mathrm{S}, 38^{\circ} 21^{\prime} 00^{\prime \prime} \mathrm{W}$ & 55 & 21 Apr. 1995 \\
\hline JOPS st. 3237 & $18^{\circ} 13^{\prime} 00^{\prime \prime} \mathrm{S}, 38^{\circ} 20^{\prime} 00^{\prime \prime} \mathrm{W}$ & 55 & 23 Apr. 1995 \\
\hline JOPS st. 3238 & $18^{\circ} 15^{\prime} 48^{\prime \prime} \mathrm{S}, 38^{\circ} 27^{\prime} 00^{\prime \prime} \mathrm{W}$ & 40 & 23 Apr. 1995 \\
\hline JOPS st. 3239 & $18^{\circ} 21^{\prime} 30^{\prime \prime} \mathrm{S}, 38^{\circ} 35^{\prime} 42^{\prime \prime} \mathrm{W}$ & 50 & 23 Apr. 1995 \\
\hline MD55 42-DC75 & $18^{\circ} 59^{\prime} 02^{\prime \prime} \mathrm{S}, 37^{\circ} 50^{\prime} 01^{\prime \prime} \mathrm{W}$ & 295 & 27 May 1987 \\
\hline PADCT st. 6571 & $24^{\circ} 12^{\prime} 44^{\prime \prime} \mathrm{S}, 44^{\circ} 58^{\prime} 59^{\prime \prime} \mathrm{W}$ & 79 & Nov. 1997-Jan. 1998 \\
\hline PADCT st. 6573 & $24^{\circ} 42^{\prime} 36^{\prime \prime} \mathrm{S}, 44^{\circ} 43^{\prime} 25^{\prime \prime} \mathrm{W}$ & 155 & Nov. 1997-Jan. 1998 \\
\hline PADCT st. 6577 & $25^{\circ} 15^{\prime} 45^{\prime \prime} \mathrm{S}, 45^{\circ} 04^{\prime} 37^{\prime \prime} \mathrm{W}$ & 124 & Nov. 1997-Jan. 1998 \\
\hline PADCT st. 6579 & $24^{\circ} 42^{\prime} 18^{\prime \prime} \mathrm{S}, 45^{\circ} 18^{\prime} 50^{\prime \prime} \mathrm{W}$ & 84 & Nov. 1997-Jan. 1998 \\
\hline PADCT st. 6595 & $26^{\circ} 23^{\prime} 33^{\prime \prime} \mathrm{S}, 46^{\circ} 39^{\prime} 29^{\prime \prime} \mathrm{W}$ & 175 & Nov. 1997-Jan. 1998 \\
\hline PADCT st. 6627 & $23^{\circ} 57^{\prime} 59^{\prime \prime} \mathrm{S}, 43^{\circ} 52^{\prime} 33^{\prime \prime} \mathrm{W}$ & 133 & Nov. 1997-Jan. 1998 \\
\hline PADCT st. 6635 & $27^{\circ} 10^{\prime} 23^{\prime \prime} \mathrm{S}, 47^{\circ} 27^{\prime} 32^{\prime \prime} \mathrm{W}$ & 129 & Nov. 1997-Jan. 1998 \\
\hline PADCT st. 6641 & $26^{\circ} 15^{\prime} 00^{\prime \prime} \mathrm{S}, 46^{\circ} 53^{\prime} 00^{\prime \prime} \mathrm{W}$ & 130 & Nov. 1997-Jan. 1998 \\
\hline PADCT st. 6642 & $25^{\circ} 49^{\prime} 18^{\prime \prime} \mathrm{S}, 46^{\circ} 34^{\prime} 00^{\prime \prime} \mathrm{W}$ & 128 & Nov. 1997-Jan. 1998 \\
\hline Petro/MAR st. 19 & $10^{\circ} 16^{\prime} 13^{\prime \prime} \mathrm{S}, 36^{\circ} 13^{\prime} 06^{\prime \prime} \mathrm{W}$ & 10 & $2002-2003$ \\
\hline Petro/MAR st. 21 & $10^{\circ} 24^{\prime} 31^{\prime \prime} \mathrm{S}, 36^{\circ} 03^{\prime} 06^{\prime \prime} \mathrm{W}$ & 30 & $2002-2003$ \\
\hline Petro/UFS st. E5-A1 & $10^{\circ} 45^{\prime} 36^{\prime \prime} \mathrm{S}, 36^{\circ} 36^{\prime} 08^{\prime \prime} \mathrm{W}$ & 20 & 1999-2000 \\
\hline Petro/UFS st. E5-A2 & $10^{\circ} 45^{\prime} 36^{\prime \prime} \mathrm{S}, 36^{\circ} 36^{\prime} 08^{\prime \prime} \mathrm{W}$ & 20 & $1999-2000$ \\
\hline Petro/UFS st. E6-A1 & $10^{\circ} 49^{\prime} 47^{\prime \prime} \mathrm{S}, 36^{\circ} 32^{\prime} 10^{\prime \prime} \mathrm{W}$ & 30 & 1999-2000 \\
\hline Petro/UFS st. E6-A2 & $10^{\circ} 49^{\prime} 47^{\prime \prime} \mathrm{S}, 36^{\circ} 32^{\prime} 10^{\prime \prime} \mathrm{W}$ & 30 & $1999-2000$ \\
\hline Petro/UFS st. E6-A4 & $10^{\circ} 49^{\prime} 47^{\prime \prime} \mathrm{S}, 36^{\circ} 32^{\prime} 10^{\prime \prime} \mathrm{W}$ & 30 & 1999-2000 \\
\hline Petro/UFS st. 12.1 & $11^{\circ} 03^{\prime} 26^{\prime \prime}$ S, 36 $33^{\circ} 21^{\prime \prime} \mathrm{W}$ & 30 & 1999 \\
\hline Petro/UFS st. 15.3 & $11^{\circ} 13^{\prime} 07^{\prime \prime} \mathrm{S}, 37^{\circ} 00^{\prime} 00^{\prime \prime} \mathrm{W}$ & 30 & 1999 \\
\hline Petro/UFS st. 18.1 & $11^{\circ} 21^{\prime} 07^{\prime \prime} \mathrm{S}, 37^{\circ} 05^{\prime} 50^{\prime \prime} \mathrm{W}$ & 30 & 1999 \\
\hline RAP-BIG st. 1 & $23^{\circ} 17^{\prime} 26^{\prime \prime} \mathrm{S}, 44^{\circ} 30^{\prime} 22^{\prime \prime} \mathrm{W}$ & - & 17 Nov. 2003 \\
\hline RAP-BIG st. 3 & $23^{\circ} 15^{\prime} 18^{\prime \prime} \mathrm{S}, 44^{\circ} 34^{\prime} 56^{\prime \prime} \mathrm{W}$ & 5 & 16 Nov. 2003 \\
\hline RAP-BIG st. 10 & $23^{\circ} 11^{\prime} 36^{\prime \prime} \mathrm{S}, 44^{\circ} 38^{\prime} 38^{\prime \prime} \mathrm{W}$ & - & 18 Nov. 2003 \\
\hline RAP-BIG st. 12 & $23^{\circ} 09^{\prime} 46^{\prime \prime} \mathrm{S}, 44^{\circ} 39^{\prime} 47^{\prime \prime} \mathrm{W}$ & - & 20 Nov. 2003 \\
\hline RAP-BIG st. 13 & $23^{\circ} 09^{\prime} 23^{\prime \prime} \mathrm{S}, 44^{\circ} 40^{\prime} 54^{\prime \prime} \mathrm{W}$ & 3 & 20 Nov. 2003 \\
\hline RAP-BIG st. 17 & $23^{\circ} 00^{\prime} 33^{\prime \prime} \mathrm{S}, 44^{\circ} 28^{\prime} 28^{\prime \prime} \mathrm{W}$ & 10 & 30 Oct. 2003 \\
\hline RAP-BIG st. 19 & $22^{\circ} 57^{\prime} 43^{\prime \prime} \mathrm{S}, 44^{\circ} 22^{\prime} 00^{\prime \prime} \mathrm{W}$ & 6 & 29 Oct. 2003 \\
\hline RAP-BIG st. 20 & $22^{\circ} 58^{\prime} 22^{\prime \prime} \mathrm{S}, 44^{\circ} 19^{\prime} 48^{\prime \prime} \mathrm{W}$ & 2.5 & 29 Oct. 2003 \\
\hline RAP-BIG st. 21 & $23^{\circ} 01^{\prime} 55^{\prime \prime} \mathrm{S}, 44^{\circ} 22^{\prime} 44^{\prime \prime} \mathrm{W}$ & 6 & 28 Oct. 2003 \\
\hline RAP-BIG st. 22 & $23^{\circ} 04^{\prime} 16^{\prime \prime} \mathrm{S}, 44^{\circ} 21^{\prime} 45^{\prime \prime} \mathrm{W}$ & 14 & 28 Oct. 2003 \\
\hline RAP-BIG st. 23 & $23^{\circ} 03^{\prime} 34^{\prime \prime} \mathrm{S}, 44^{\circ} 25^{\prime} 15^{\prime \prime} \mathrm{W}$ & - & 31 Oct. 2003 \\
\hline RAP-BIG st. 24 & $23^{\circ} 05^{\prime} 53^{\prime \prime} \mathrm{S}, 44^{\circ} 24^{\prime} 24^{\prime \prime} \mathrm{W}$ & 22 & 31 Oct. 2003 \\
\hline RAP-BIG st. 26 & $23^{\circ} 01^{\prime} 40^{\prime \prime} \mathrm{S}, 44^{\circ} 18^{\prime} 34^{\prime \prime} \mathrm{W}$ & 5 & 2 Nov. 2003 \\
\hline RAP-BIG st. 30 & $23^{\circ} 04^{\prime} 43^{\prime \prime} \mathrm{S}, 44^{\circ} 13^{\prime} 29^{\prime \prime} \mathrm{W}$ & 14 & 1 Dec. 2003 \\
\hline RAP-BIG st. 31 & $23^{\circ} 06^{\prime} 07^{\prime \prime} \mathrm{S}, 44^{\circ} 11^{\prime} 26^{\prime \prime} \mathrm{W}$ & 6 & 1 Dec. 2003 \\
\hline
\end{tabular}


Table 1 (continued). Scientific expeditions that sampled most material listed in this study.

\begin{tabular}{|c|c|c|c|}
\hline Expedition/station & Coordinates & Depth (m) & Date \\
\hline RAP-BIG st. 32 & $23^{\circ} 07^{\prime} 28^{\prime \prime} \mathrm{S}, 44^{\circ} 08^{\prime} 51^{\prime \prime} \mathrm{W}$ & 8 & 5 Dec. 2003 \\
\hline RAP-BIG st. 34 & $23^{\circ} 10^{\prime} 05^{\prime \prime} \mathrm{S}, 44^{\circ} 09^{\prime} 00^{\prime \prime} \mathrm{W}$ & - & 4 Dec. 2003 \\
\hline RAP-BIG st. 35 & $23^{\circ} 13^{\prime} 16^{\prime \prime} \mathrm{S}, 44^{\circ} 09^{\prime} 00^{\prime \prime} \mathrm{W}$ & 19 & 4 Dec. 2003 \\
\hline RAP-BIG st. 36 & $23^{\circ} 12^{\prime} 15^{\prime \prime} \mathrm{S}, 44^{\circ} 15^{\prime} 21^{\prime \prime} \mathrm{W}$ & 35 & 3 Dec. 2003 \\
\hline RAP-BIG st. 37 & $23^{\circ} 11^{\prime} 33^{\prime \prime} \mathrm{S}, 44^{\circ} 18^{\prime} 55^{\prime \prime} \mathrm{W}$ & 15 & 3 Dec. 2003 \\
\hline RAP-BIG st. 38 & $23^{\circ} 10^{\prime} 02^{\prime \prime} \mathrm{S}, 44^{\circ} 22^{\prime} 21^{\prime \prime} \mathrm{W}$ & 13 & 6 Dec. 2003 \\
\hline RAP-BIG st. 39 & $23^{\circ} 08^{\prime} 15^{\prime \prime} \mathrm{S}, 44^{\circ} 19^{\prime} 35^{\prime \prime} \mathrm{W}$ & 15 & 6 Dec. 2003 \\
\hline RAP-BIG st. 40 & $23^{\circ} 06^{\prime} 48^{\prime \prime} \mathrm{S}, 44^{\circ} 17^{\prime} 49^{\prime \prime} \mathrm{W}$ & 16 & 7 Dec. 2003 \\
\hline REVIZEE-Central C1-D1 & $22^{\circ} 23^{\prime} 17^{\prime \prime} \mathrm{S}, 37^{\circ} 36^{\prime} 54^{\prime \prime} \mathrm{W}$ & 105 & 8 Feb.1996 \\
\hline REVIZEE-Central C1-D1-2 & $22^{\circ} 49^{\prime} 05^{\prime \prime} \mathrm{S}, 41^{\circ} 09^{\prime} 25^{\prime \prime} \mathrm{W}$ & 69 & 23 Feb.1996 \\
\hline REVIZEE-Central C1-D3 & $22^{\circ} 04^{\prime} 30^{\prime \prime} \mathrm{S}, 40^{\circ} 04^{\prime} 55^{\prime \prime} \mathrm{W}$ & 80 & 13 Feb.1996 \\
\hline REVIZEE-Central C1-VV16 & $21^{\circ} 10^{\prime} 59^{\prime \prime} \mathrm{S}, 40^{\circ} 27^{\prime} 04^{\prime \prime} \mathrm{W}$ & 28 & 26 Feb.1996 \\
\hline REVIZEE-Central C1-VV17 & $21^{\circ} 09^{\prime} 58^{\prime \prime} \mathrm{S}, 40^{\circ} 27^{\prime} 04^{\prime \prime} \mathrm{W}$ & 27 & 26 Feb.1996 \\
\hline REVIZEE-Central C1-VV21 & $20^{\circ} 38^{\prime} 02^{\prime \prime} \mathrm{S}, 40^{\circ} 01^{\prime} 19^{\prime \prime} \mathrm{W}$ & 56 & 27 Feb.1996 \\
\hline REVIZEE-Central C1-VV22 & $20^{\circ} 20^{\prime} 24^{\prime \prime} \mathrm{S}, 40^{\circ} 05^{\prime} 56^{\prime \prime} \mathrm{W}$ & 33 & 27 Feb.1996 \\
\hline REVIZEE-Central C1-VV24 & $20^{\circ} 00^{\prime} 18^{\prime \prime} \mathrm{S}, 39^{\circ} 54^{\prime} 36^{\prime \prime} \mathrm{W}$ & 45 & 27 Feb.1996 \\
\hline REVIZEE-Central C1-VV31 & $18^{\circ} 52^{\prime} 33^{\prime \prime} \mathrm{S}, 39^{\circ} 35^{\prime} 13^{\prime \prime} \mathrm{W}$ & 23 & 28 Feb.1996 \\
\hline REVIZEE-Central C1-VV33 & $18^{\circ} 53^{\prime} 17^{\prime \prime} \mathrm{S}, 39^{\circ} 13^{\prime} 52^{\prime \prime} \mathrm{W}$ & 37 & 28 Feb.1996 \\
\hline REVIZEE-Central C1-VV38 & $19^{\circ} 28^{\prime} 26^{\prime \prime} \mathrm{S}, 38^{\circ} 22^{\prime} 30^{\prime \prime} \mathrm{W}$ & 71 & 29 Feb.1996 \\
\hline REVIZEE-Central C1-C61 & $20^{\circ} 30^{\prime} 22^{\prime \prime} \mathrm{S}, 37^{\circ} 19^{\prime} 05^{\prime \prime} \mathrm{W}$ & 88 & 24 Apr. 1996 \\
\hline REVIZEE-Central C1-C63 & $19^{\circ} 40^{\prime} 26^{\prime \prime} \mathrm{S}, 38^{\circ} 08^{\prime} 10^{\prime \prime} \mathrm{W}$ & 61 & 25 Apr. 1996 \\
\hline REVIZEE-Central C1-C64 & $19^{\circ} 16^{\prime} 58^{\prime \prime} \mathrm{S}, 38^{\circ} 42^{\prime} 00^{\prime \prime} \mathrm{W}$ & 63 & 25 Apr. 1996 \\
\hline REVIZEE-Central C1-C65 & $18^{\circ} 52^{\prime} 58^{\prime \prime} \mathrm{S}, 39^{\circ} 06^{\prime} 00^{\prime \prime} \mathrm{W}$ & 50 & 25 Apr. 1996 \\
\hline REVIZEE-Central C1-C66 & $18^{\circ} 19^{\prime} 58^{\prime \prime} \mathrm{S}, 38^{\circ} 55^{\prime} 01^{\prime \prime} \mathrm{W}$ & 41 & 26 Apr. 1996 \\
\hline REVIZEE-Central C1-C76 & $15^{\circ} 53^{\prime} 49^{\prime \prime} \mathrm{S}, 38^{\circ} 31^{\prime} 05^{\prime \prime} \mathrm{W}$ & 66 & 30 Apr. 1996 \\
\hline REVIZEE-Central C2-7R & $16^{\circ} 19^{\prime} 55^{\prime \prime} \mathrm{S}, 38^{\circ} 14^{\prime} 38^{\prime \prime} \mathrm{W}$ & 58 & 26 Oct. 1997 \\
\hline REVIZEE-Central C2-10R & $17^{\circ} 05^{\prime} 53^{\prime \prime} \mathrm{S}, 36^{\circ} 45^{\prime} 07^{\prime \prime} \mathrm{W}$ & 50 & 14 Nov. 1997 \\
\hline REVIZEE-Central C2-22R & $20^{\circ} 30^{\prime} 40^{\prime \prime} \mathrm{S}, 35^{\circ} 50^{\prime} 17^{\prime \prime} \mathrm{W}$ & 59 & 8 Nov. 1997 \\
\hline REVIZEE-Central C2-35R & $20^{\circ} 52^{\prime} 01^{\prime \prime} \mathrm{S}, 40^{\circ} 10^{\prime} 01^{\prime \prime} \mathrm{W}$ & 55 & 3 Nov. 1997 \\
\hline REVIZEE-Central C2-36R & $21^{\circ} 31^{\prime} 01^{\prime \prime} \mathrm{S}, 40^{\circ} 18^{\prime} 00^{\prime \prime} \mathrm{W}$ & 52 & 4 Nov. 1997 \\
\hline REVIZEE-Central C5-4R & $14^{\circ} 48^{\prime} 29^{\prime \prime} \mathrm{S}, 38^{\circ} 55^{\prime} 01^{\prime \prime} \mathrm{W}$ & 20 & 1 Jul. 2001 \\
\hline REVIZEE-Central C5-7R & $16^{\circ} 07^{\prime} 01^{\prime \prime} \mathrm{S}, 38^{\circ} 10^{\prime} 12^{\prime \prime} \mathrm{W}$ & 40 & 30 Jun. 2001 \\
\hline REVIZEE-Central C5-12R & $17^{\circ} 02^{\prime} 31^{\prime \prime} \mathrm{S}, 37^{\circ} 36^{\prime} 29^{\prime \prime} \mathrm{W}$ & 50 & 30 Jun. 2001 \\
\hline REVIZEE-Central C5-13R & $16^{\circ} 47^{\prime} 10^{\prime \prime} \mathrm{S}, 37^{\circ} 41^{\prime} 10^{\prime \prime} \mathrm{W}$ & 50 & 30 Jun. 2001 \\
\hline REVIZEE-Central C5-16R & $18^{\circ} 03^{\prime} 32^{\prime \prime} \mathrm{S}, 37^{\circ} 18^{\prime} 54^{\prime \prime} \mathrm{W}$ & 100 & 29 Jun. 2001 \\
\hline REVIZEE-Central C5-20R & $19^{\circ} 16^{\prime} 19^{\prime \prime} \mathrm{S}, 38^{\circ} 01^{\prime} 08^{\prime \prime} \mathrm{W}$ & 67 & 28 Jun. 2001 \\
\hline REVIZEE-Central C5-23R & $20^{\circ} 29^{\prime} 13^{\prime \prime} \mathrm{S}, 36^{\circ} 06^{\prime} 11^{\prime \prime} \mathrm{W}$ & 55 & 12 Jul. 2001 \\
\hline REVIZEE-Central C5-28R & $19^{\circ} 48^{\prime} 29^{\prime \prime} \mathrm{S}, 37^{\circ} 56^{\prime} 20^{\prime \prime} \mathrm{W}$ & 60 & 18 Jul. 2001 \\
\hline REVIZEE-Central C6-R2\#1-1 & $19^{\circ} 45^{\prime} 36^{\prime \prime} \mathrm{S}, 39^{\circ} 31^{\prime} 05^{\prime \prime} \mathrm{W}$ & 92 & 15 Jun. 2002 \\
\hline REVIZEE-Central C6-Y7 & $20^{\circ} 50^{\prime} 56^{\prime \prime} \mathrm{S}, 40^{\circ} 10^{\prime} 01^{\prime \prime} \mathrm{W}$ & 75 & 28 Jun. 2002 \\
\hline REVIZEE-Sul st. 6646 & $25^{\circ} 43^{\prime} 47^{\prime \prime} \mathrm{S}, 45^{\circ} 16^{\prime} 03^{\prime \prime} \mathrm{W}$ & 198 & 14 Dec. 1997 \\
\hline REVIZEE-Sul st. 6653 & $25^{\circ} 43^{\prime} 30^{\prime \prime} \mathrm{S}, 46^{\circ} 02^{\prime} 30^{\prime \prime} \mathrm{W}$ & 155 & 15 Dec. 1997 \\
\hline REVIZEE-Sul st. 6657 & $25^{\circ} 17^{\prime} 18^{\prime \prime} \mathrm{S}, 46^{\circ} 55^{\prime} 36^{\prime \prime} \mathrm{W}$ & 60 & 16 Dec. 1997 \\
\hline REVIZEE-Sul st. 6662 & $24^{\circ} 00^{\prime} 57^{\prime \prime} \mathrm{S}, 43^{\circ} 55^{\prime} 32^{\prime \prime} \mathrm{W}$ & 135 & 9 Jan. 1998 \\
\hline REVIZEE-Sul st. 6666 & $24^{\circ} 17^{\prime} 08^{\prime \prime} \mathrm{S}, 44^{\circ} 12^{\prime} 09^{\prime \prime} \mathrm{W}$ & 163 & 10 Jan. 1998 \\
\hline REVIZEE-Sul st. 6669 & $24^{\circ} 07^{\prime} 25^{\prime \prime} \mathrm{S}, 44^{\circ} 42^{\prime} 13^{\prime \prime} \mathrm{W}$ & 101 & 11 Jan. 1998 \\
\hline REVIZEE-Sul st. 6676 & $24^{\circ} 49^{\prime} 42^{\prime \prime} \mathrm{S}, 44^{\circ} 44^{\prime} 58^{\prime \prime} \mathrm{W}$ & 153 & 12 Jan. 1998 \\
\hline REVIZEE-Sul st. 6678 & $24^{\circ} 46^{\prime} 21^{\prime \prime} \mathrm{S}, 45^{\circ} 11^{\prime} 08^{\prime \prime} \mathrm{W}$ & 100 & 12 Jan. 1998 \\
\hline REVIZEE-Sul st. 6686 & $25^{\circ} 37^{\prime} 01^{\prime \prime} \mathrm{S}, 45^{\circ} 13^{\prime} 35^{\prime \prime} \mathrm{W}$ & 153 & 13 Jan. 1998 \\
\hline REVIZEE-Sul st. 6699 & $26^{\circ} 01^{\prime} 19^{\prime \prime} \mathrm{S}, 46^{\circ} 25^{\prime} 15^{\prime \prime} \mathrm{W}$ & 153 & 20 Jan. 1998 \\
\hline
\end{tabular}


Zona Econômica Exclusiva [Program of Evaluation of the Sustainable Potential of Living Resources in the Exclusive Economic Zone], Score Norte: OC. Ship Antares coll., Score Central: OC. Ship Antares and supply-boat Astro Garoupa coll., Score Sul: OC. Ship Prof. W. Besnard coll.; (UEPB) Universidade Estadual da Paraíba, Campina Grande, Brazil; (UERJ) Universidade do Estado do Rio de Janeiro, Rio de Janeiro, Brazil; (UFC-Labomar) Universidade Federal do Ceará, Instituto de Ciências do Mar, Fortaleza, Brazil; (UFMA) Universidade Federal do Maranhão, São Luís, Brazil; (UFRPE) Universidade Federal Rural de Pernambuco, Recife, Brazil; (UFS) Universidade Federal de Sergipe, Aracaju, Brazil; (ZUEC-GAS) collection of Gastropoda of the Museu de Zoologia, Universidade Estadual de Campinas - UNICAMP, Campinas, Brazil.

The recent fire at MNRJ (Zamudio et al. 2018) destroyed most lots from this institution listed in the present study, in addition to several ones lent from MORG, MZUSP and others; destroyed lots are marked by an asterisk (*) in the material examined and the figure legends as well as in the Appendix. However, types were photographed and detailed descriptions and illustrations are provided for all species. Three of the five new species do not have extant material in any scientific collection, but this does not preclude the establishment of new names (ICZN 1999: articles 72.5.6 and 73.1.4; ICZN 2017; Krell \& Marshall 2017). Regarding the fact that the new species live in localities hard to access without major financial support (such as remote islands or the deepest zones of the continental shelf) and that the detailed descriptions and illustrations herein given allow species to be easily recognized, the authors do not refrain of providing new specific names.

\section{Results}

\section{Taxonomic account}

Family Triphoridae Gray, 1847

Subfamily Triphorinae Gray, 1847

Genus Cheirodonta Marshall, 1983

\section{Type species}

Cerithium perversum var. pallescens Jeffreys, 1867. Original designation. Recent, northeastern Atlantic and Mediterranean.

Cheirodonta dupliniana (Olsson, 1916)

Figs 1, 22G, 29, 83

Triphora dupliniana Olsson, 1916: 138, pl. 3 fig. 8.

Triphora bolax Olsson \& Harbison, 1953: 295, pl. 43 fig. 4.

Cheirodonta mizifio Fernandes \& Pimenta, 2015: 496, fig. 2.

Triphora dupliniana - Gardner 1948: 205, pl. 27 fig. 3. — Treece 1980: 560. — Miller 1989: 96.

Cosmotriphora dupliniana — Rosenberg et al. 2009: 645.

Triphora sp. 1 - Daccarett \& Bossio 2011: fig. 423.

Cheirodonta dupliniana - Fernandes \& Pimenta 2019a: 12, figs 5-6.

Triphora perversa nigrocincta non C.B. Adams, 1839 - Perry \& Schwengel 1955: 139, pl. 27 fig. 189, partim.

Triphora lilacina non Dall, 1889 - Vokes \& Vokes 1983: 18, pl. 27 fig. 13.

Triphora hemphilli non Bartsch, 1907 - Odé 1989: 112. — Tunnell et al. 2010. 
Marshallora nigrocincta non C.B. Adams, 1839 - Lee 2009: 89, partim.

Sagenotriphora osclausum non Rolán \& Fernández-Garcés, 1995 - Garcia \& Lee 2011.

Triphora oreodoxa non Olsson \& Harbison, 1953 - Garcia \& Lee 2011.

\section{Material examined}

Lectotype (herein designated)

UNITED STATES OF AMERICA - North Carolina • Natural Well; Duplin formation, Miocene; figured in Olsson 1916; PRI 1376.

\section{Paralectotype}

UNITED STATES OF AMERICA - Virginia - 1 spec.; James River, north of Smithfield; Yorktown Formation, Miocene; PRI 11016.

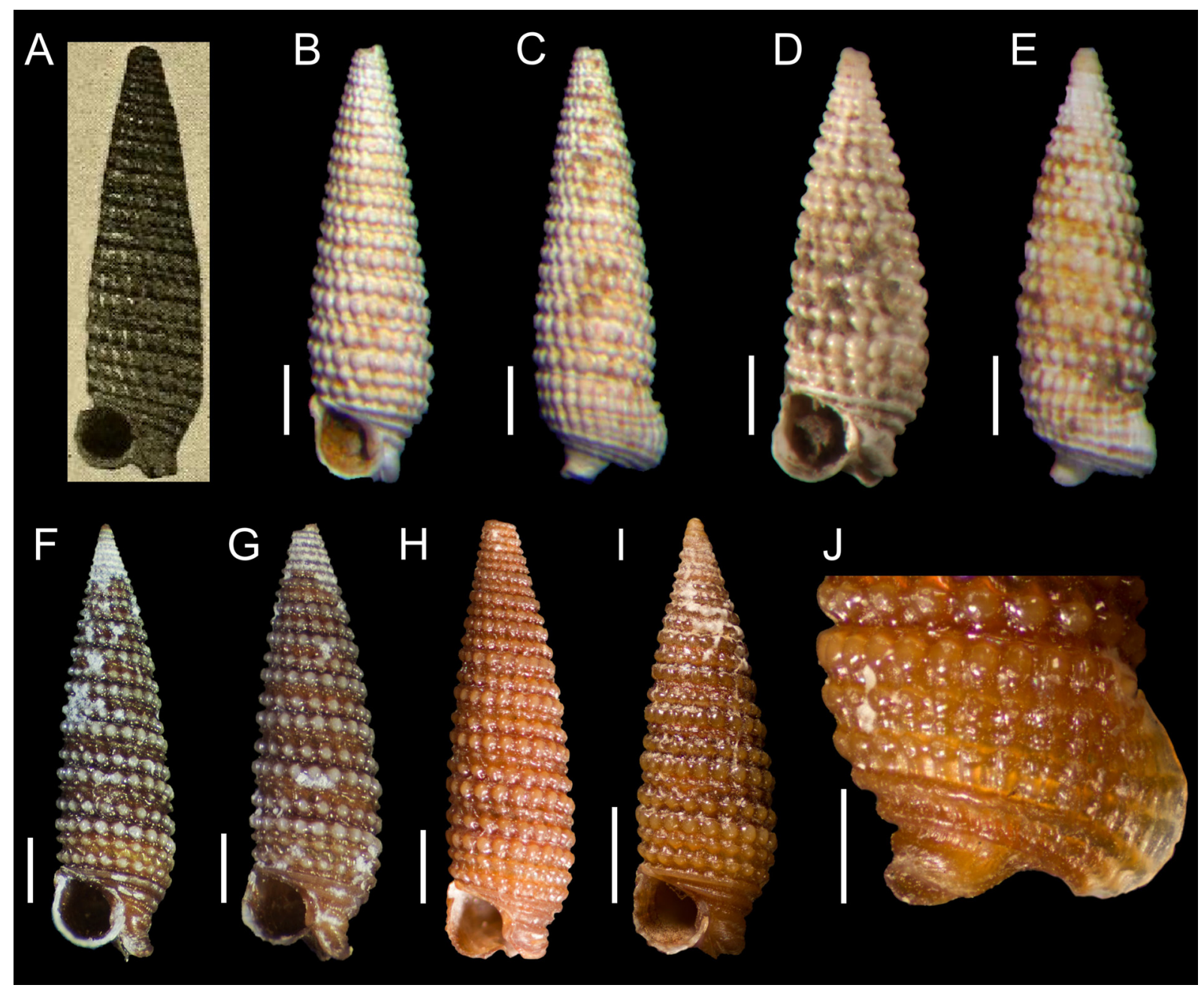

Fig. 1. Cheirodonta dupliniana (Olsson, 1916). A-C. PRI 1376, $5.75 \mathrm{~mm}$ (original description) or $6.31 \mathrm{~mm}$ (scale bar provided), lectotype, illustrated in Olsson (1916). D-E. PRI 11016, $5.57 \mathrm{~mm}$, paralectotype, not illustrated in Olsson (1916). F-G. MCZ 34426, $6.75 \mathrm{~mm}$ and $6.35 \mathrm{~mm}$, respectively. H. FLMNH 160564, $6.00 \mathrm{~mm}$. I-J. FLMNH 507930, $4.60 \mathrm{~mm}$. Scale bars: B-I = $1 \mathrm{~mm} ; \mathrm{J}=500 \mu \mathrm{m}$. Photo credits B-E: Leslie Skibinski (Cornell University). 


\section{Other material}

BRAZIL - Fernando de Noronha Archipelago - 2 specs; Porto; depth 6 m; 20 Jul. 1999; P. Souza and L. Simone leg.; MZSP 32023. See Fernandes \& Pimenta (2015) for other localities.

PANAMA • 4 specs; Colón Island, Bocas del Toro; 1 Mar. 1953; McGinty leg.; FLMNH 160564.

UNITED STATES OF AMERICA - Connecticut • 9 specs; Branford; W.H. Winkley leg.; MCZ 34426. - South Carolina • 1 spec.; 32²9'36" N, 7942'30" W; depth 18 m; 26 Jul. 1981; R/V Bagby leg.; USNM 850620. - Florida - 4 specs; off Yamato Rocks, Palm Beach; 26 Apr. 1939; F.B. Lyman leg., FLMNH 507930 • 1 spec.; off Palm Beach; depth 183 m; T.L. McGuity leg.; MCZ 244439 • 3 specs; Sanibel Island, Tarpon Bay; W.J. Clench and B. Chandler leg.; MCZ 256788 12 specs; $0.8 \mathrm{~km}$ E of Sanibel Island; depth 11-27 m; 1933; W.J. Clench and B. Chandler leg.; MCZ $256794 \bullet 1$ spec.; 4.8 km SW of Sanibel Lighthouse; depth 44-49 m; 1933; W.J. Clench and B. Chandler leg.; MCZ 356053 • 1 spec.; Sanibel Island; BMSM 20533 • 1 spec.; Middle Gulf shore, Sanibel Island; BMSM 33601 • 6 specs; Sanibel Island; 1935; L. Perry leg.; USNM 617570 • 1 spec.; off Kice Island, Ten Thousand Islands; BMSM 67455.

\section{Remarks}

Triphora dupliniana Olsson, 1916 and Triphora bolax Olsson \& Harbison, 1953 were described as fossils from the Miocene/Pliocene, the former from Virginia and North Carolina, the latter from Florida (USA). The scarcity of integrative researches comprising fossil and Recent material precluded the use of both names in the literature of extant triphorids. Our analysis of several lots in malacological collections in the USA revealed that many shells originally labeled as Marshallora nigrocincta (C.B. Adams, 1839) or Marshallora sp. actually consist of Cheirodonta dupliniana (Olsson, 1916), including references in the literature (e.g., Lee 2009). Cheirodonta bolax (Olsson \& Harbison, 1953) comb. nov. and Cheirodonta mizifio Fernandes \& Pimenta, 2015 (described from Brazil) are regarded as junior synonyms of $C$. dupliniana owing to their identical shell morphology. If enough live material of C. dupliniana is posteriorly obtained, genetic comparisons of specimens from Brazil (C. mizifio) and "Caribbean" (C. dupliniana) could test the validity of the synonyms herein proposed.

The shell identified by Olsson \& Harbison (1953: pl. 43 fig. 2) as T. dupliniana from the Pliocene of Florida (USA) actually belongs to Marshallora Bouchet, 1985.

\section{Geographical records}

USA: Connecticut (this study), Virginia (Olsson 1916), North Carolina (type locality of C. dupliniana), South Carolina to Florida (this study; Florida is the type locality of C. bolax), Louisiana (Garcia \& Lee 2011; as Sagenotriphora osclausum and Triphora oreodoxa), Texas (Odé (1989) and Tunnell et al. (2010) as Triphora hemphilli); Mexico (Treece 1980; Vokes \& Vokes 1983, as Triphora lilacina); Panama (this study); Colombia (Daccarett \& Bossio 2011, as Triphora sp. 1); Brazil: Fernando de Noronha Archipelago (this study), Rio Grande do Norte, Bahia to Rio de Janeiro (Fernandes \& Pimenta 2015, as Cheirodonta mizifio).

\section{Bathymetric distribution}

Depth: 6-183 m (this study).

Genus Eutriphora Cotton \& Godfrey, 1931

\section{Type species}

Triphora cana Verco, 1909. Original designation. Recent, southern Australia. 
Eutriphora auffenbergi Rolán \& Lee, 2008

Figs 2, 22K, 33

Eutriphora auffenbergi Rolán \& Lee in Rolán \& Fernández-Garcés 2008: 92, fig. 6.

Eutriphora auffenbergi - Lee 2009: 88.

\section{Material examined}

Holotype

UNITED STATES OF AMERICA - Florida - West of Dry Tortugas, Monroe County; depth 90 m; FLMNH 419186.

\section{Paratypes}

See Rolán \& Fernández-Garcés (2008).

\section{Other material}

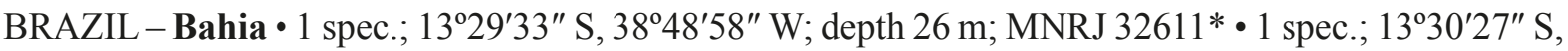
$38^{\circ} 48^{\prime} 43^{\prime \prime}$ W; depth 29 m; 25 Nov. 2010; MNRJ 32995*• 1 spec.; 1330'35" S, 3847'05" W; depth 42 m;

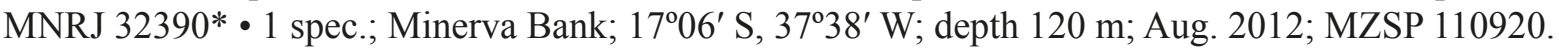

MEXICO - 2 specs; Yucatan; depth 84-89 m; BMSM 107192.

UNITED STATES OF AMERICA - Florida • 5 specs; near Carrabelle, Franklin County; Aug. 1963; J. Moore leg.; BMSM 67500 • 1 spec.; west of Anna Maria Island, Manatee County; depth 122 m; J. Moore leg.; BMSM 107195 • 1 spec.; off Fort Myers; depth 18-36 m; BMSM 67496 • 1 spec.; off Marco Island, Collier County; depth 55-61 m; Sep. 1964; J. Moore leg.; BMSM 107198.

\section{Description}

Shell sinistral, very elongated, conical, nearly rectilinear profile, up to $16.0 \mathrm{~mm}$ long (broken apex), $3.3 \mathrm{~mm}$ wide, length/width ratio 4.6 to 5.2. Protoconch multispiral, conical or columnar, $0.49 \mathrm{~mm}$ long, $0.40 \mathrm{~mm}$ wide, 4.25 convex whorls; embryonic shell dome-shaped, entirely covered by rounded granules; larval shell with two spiral cords, situated at $\sim 35 \%$ and $\sim 64 \%$ of last whorl height, adapical one disappearing just before transition to teleoconch; $\sim 31$ nearly rectilinear to slightly sigmoid axial ribs. Teleoconch with up to 16 whorls (broken apex); two spiral cords (adapical and abapical) at beginning, abapical one continuing to that of protoconch; median spiral cord emerges in third whorl, reaching same size of other cords after one to 1.5 whorl; on body whorl, distance between spiral cords $1.3-1.6 \times$ higher than width of cords; 19 opisthocline axial ribs; rounded to slightly elliptical nodules of medium to moderately small size; distinct and well-developed suture, with small sutural cord; moderately nodulose to considerably wavy subperipheral and adapical basal cords, smooth median and abapical basal cords (only one shell had three cords); one supranumerical cord may be present, between median and abapical spiral cords; ovate to almost circular aperture, $0.93-2.00 \mathrm{~mm}$ long, $0.68-1.52 \mathrm{~mm}$ wide, length/width ratio 1.2-1.4; anterior canal curved downwards, being very long in large shells, often closed, crossed in its base by projection of outer lip, $0.52-1.54 \mathrm{~mm}$ long, $0.73-0.93 \mathrm{~mm}$ wide, length/width ratio $1.6-2.0$; posterior canal as small sinus, not detached from aperture, $0.24-0.28 \mathrm{~mm}$ long. Cream, beige or brown shell, protoconch and base darker than remaining shell, first 1.5 whorl of teleoconch can be whitish.

\section{Remarks}

This is one of the largest triphorids from Brazil. Shells from Bahia State slightly differ from those of Florida (USA): the holotype has a strong and exposed sutural cord, resulting in a thick subperipheral cord (Fig. 2B), but shells from Bahia present a less developed and partially hidden sutural cord (Fig. 2I), 
similar to one paratype from Florida (Rolán \& Fernández-Garcés 2008: fig. 6d). In addition, the median spiral cord of the teleoconch emerges in the fourth/fifth whorl in shells from Florida (Rolán \& FernándezGarcés 2008), but in the third whorl in the single complete shell from Bahia (Fig. 2F), herein regarded as a minor discrepancy.

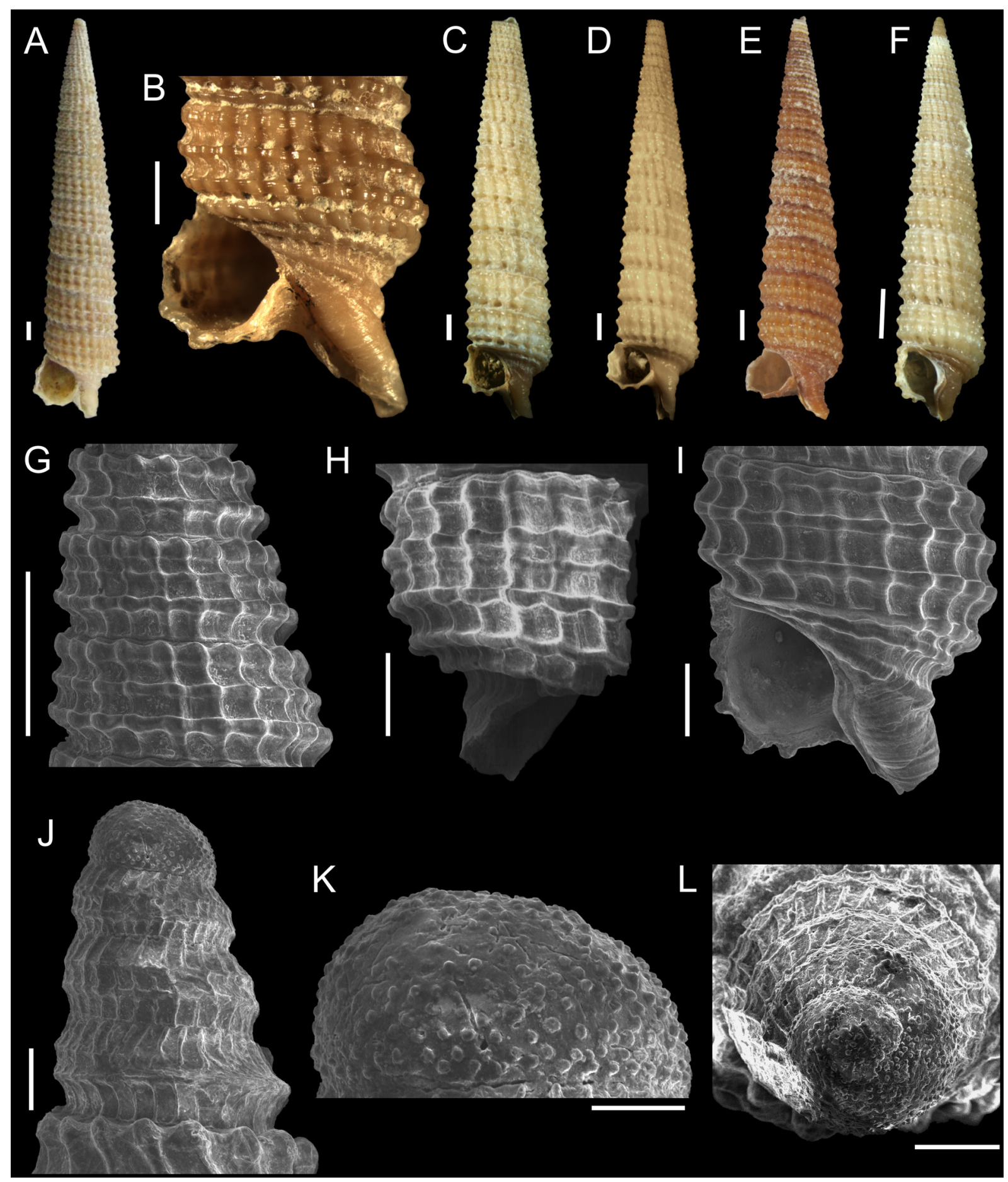

Fig. 2. Eutriphora auffenbergi Rolán \& Lee, 2008. A-B. FLMNH 419186, holotype, $21.8 \mathrm{~mm}$. C. MNRJ 32390*, $16.00 \mathrm{~mm}$. D. MNRJ 32611*, $15.28 \mathrm{~mm}$. E. MZSP 110920, $13.35 \mathrm{~mm}$. F. MNRJ 32995*, $8.70 \mathrm{~mm}$. G-L. Same shell as F. Scale bars: A-F $=1 \mathrm{~mm} ; \mathrm{G}-\mathrm{I}=500 \mu \mathrm{m}$; $\mathrm{J}, \mathrm{L}=100 \mu \mathrm{m} ; \mathrm{K}=50 \mu \mathrm{m}$. 
In addition to differences noted by Fernandes \& Pimenta (2015) to separate Eutriphora costai Fernandes \& Pimenta, 2015 from E. auffenbergi, shells of E. auffenbergi from Bahia have almost one less protoconch whorl (Fig. 2J), an earlier emergence and development of the median spiral cord of the teleoconch, and a single supranumerical cord (Fig. 2H), not four as in E. costai. Moreover, the base is slightly darker in shells of E. auffenbergi. Although Bahia State represents the southern geographical limit of E. auffenbergi (Fig. 34), it is the northern limit of E. costai (Fig. 35).

\section{Geographical records}

USA: Florida (Rolán \& Fernández-Garcés 2008; Lee 2009); Mexico (this study); Brazil: Bahia (this study).

\section{Bathymetric distribution}

Depth: 5 m (Rolán \& Fernández-Garcés 2008) to 122 m (this study). Depths of 274 m and 183-578 m indicated in Rolán \& Fernández-Garcés (2008) are suspicious, as they may be related to downslope transport.

Genus Isotriphora Cotton \& Godfrey, 1931

\section{Type species}

Triforis tasmanica Tenison-Woods, 1875. Original designation. Recent, southern Australia.

Isotriphora tricingulata Rolán \& Fernández-Garcés, 2015

Figs 3, 23G, 50

Isotriphora tricingulata Rolán \& Fernández-Garcés, 2015: 47, fig. 2.

“Isotriphora"sp. - Zhang 2011: 99, fig. 296.

\section{Material examined}

\section{Holotype}

GUADELOUPE • Port-Louis, Grand Cul-de-Sac Marin; depth 81 m; MNHN IM-2000-30472.

\section{Other material}

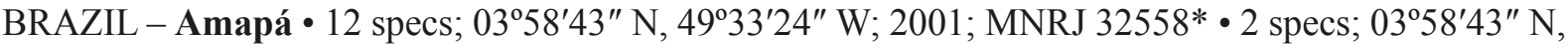

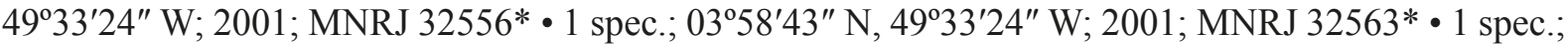

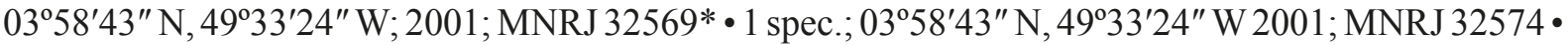
1 spec.; $02^{\circ} 45^{\prime} \mathrm{N}, 48^{\circ} 42^{\prime}$ W; depth 75 m; Nov. 2008; MNRJ 17929* • 1 spec.; 02²1'12" N, 48 $29^{\prime} 54^{\prime \prime}$ W; depth 72 m; Mar. 1997; MORG 52263.

\section{Description}

Shell sinistral, small, cyrtoconoid, rectilinear profile, up to $4.6 \mathrm{~mm}$ long, $1.4 \mathrm{~mm}$ wide, length/width ratio 2.8 to 3.1, up to 11 whorls. Protoconch paucispiral with truncated apex, without clear differentiation of the teleoconch; two strongly nodulose spiral cords starting from the slightly pointed and very narrow nucleus, situated at $\sim 37 \%$ and $\sim 73 \%$ of the last whorl height; median spiral cord usually emerging in the fifth whorl of the shell, sometimes as early as the end of fourth whorl or as late as the end of the sixth whorl, and readily reaching the same size of other cords; on the body whorl, distance between spiral cords is $0.9-1.2 \times$ higher than width of cords; $17-20$ orthocline to slightly opisthocline axial ribs at seventh whorl of shell; rounded to slightly elliptical nodules of medium size; distinct and welldeveloped suture, with small sutural cord; wavy subperipheral cord, mainly not developing nodules, 
two thin and nearly smooth basal cords, abapical one almost indistinct in some cases; no supranumerical cords; ovate aperture, $0.55-0.62 \mathrm{~mm}$ long, $0.47-0.50 \mathrm{~mm}$ wide, length/width ratio 1.2 ; anterior canal curved backwards/downwards, short, open or partly closed by projection of outer lip, $0.24-0.30 \mathrm{~mm}$ long, $0.14-0.17 \mathrm{~mm}$ wide, length/width ratio 1.7-1.8; posterior canal is small sinus, $0.09-0.11 \mathrm{~mm}$ long,
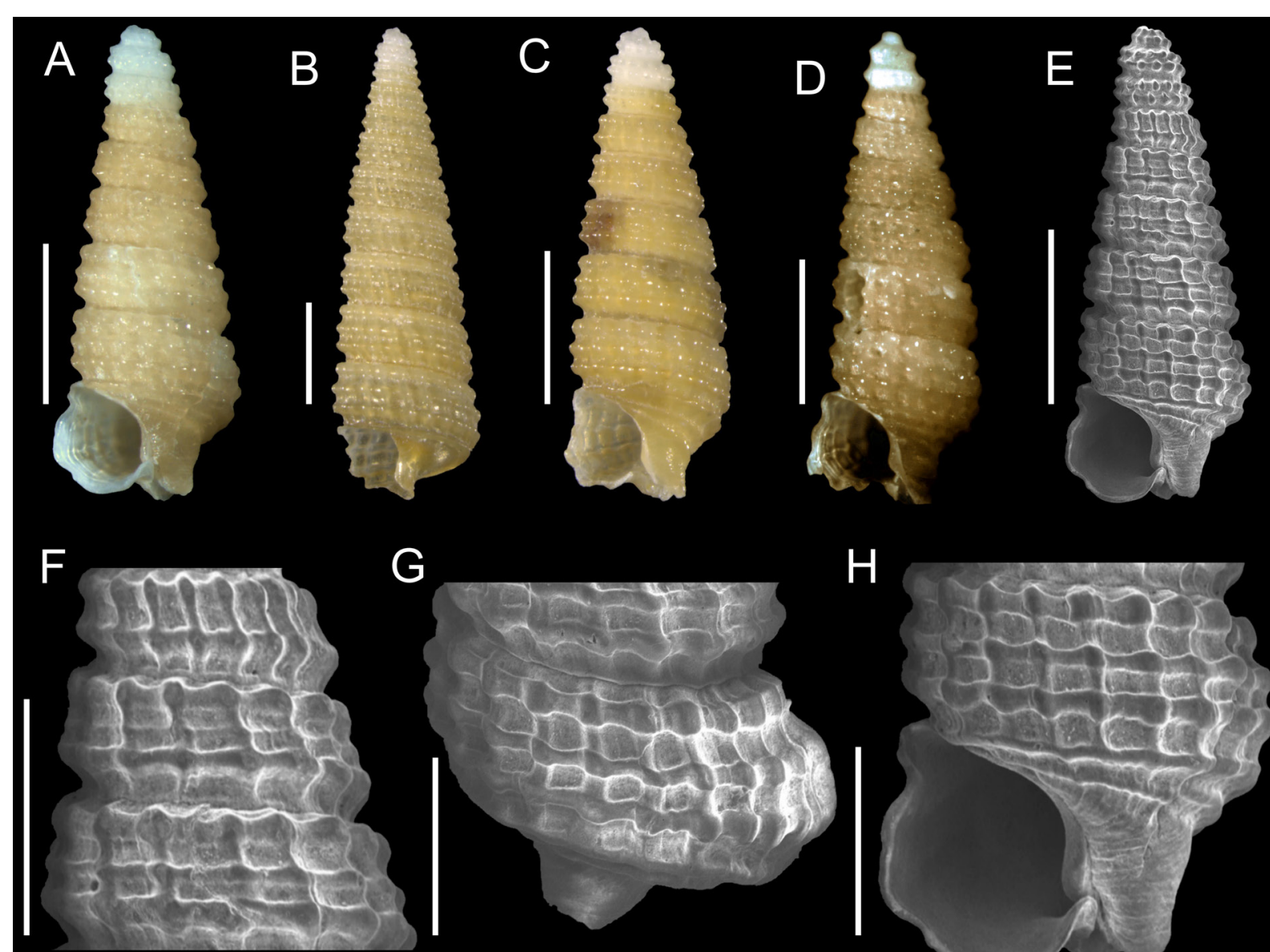

G
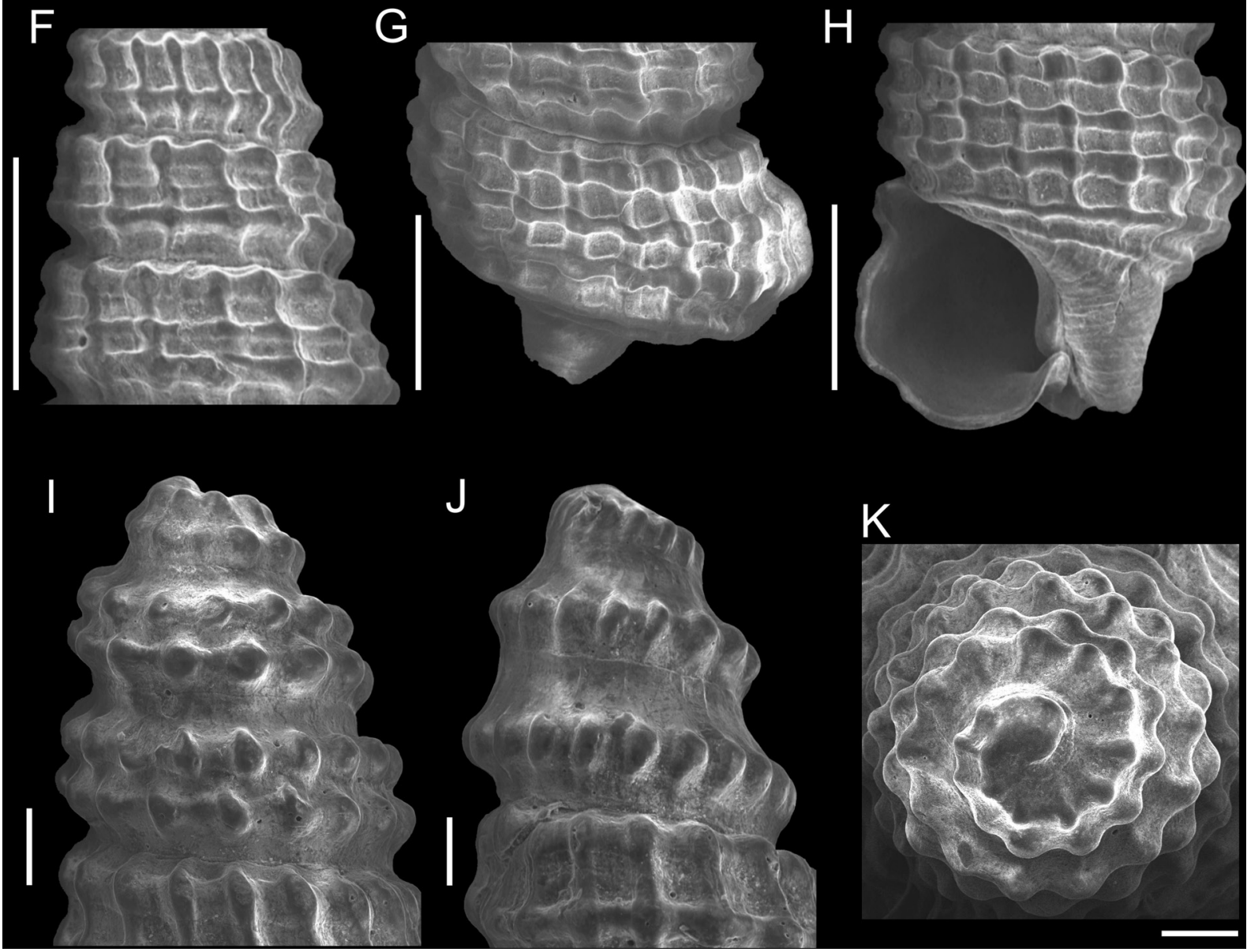

Fig. 3. Isotriphora tricingulata Rolán \& Fernández-Garcés, 2015. A, C. MNRJ 32558*, $2.75 \mathrm{~mm}$ and $3.04 \mathrm{~mm}$, respectively. B. MNRJ 17929*, $4.62 \mathrm{~mm}$. D. MNRJ 32574*, $3.29 \mathrm{~mm}$. E-I, K. Same shell as A. J. Same shell as D. Scale bars: A-E $=1 \mathrm{~mm} ; \mathrm{F}-\mathrm{H}=500 \mu \mathrm{m} ; \mathrm{I}-\mathrm{K}=100 \mu \mathrm{m}$. 
not detached from aperture. Two to three initial whorls white, remaining whorls homogeneously cream or light brown; worn shells dirty white.

\section{Remarks}

As indicated in the original description, the shell of I. tricingulata superficially resembles that of Isotriphora peetersae (Moolenbeek \& Faber, 1989), a species widely distributed throughout the Caribbean (Moolenbeek \& Faber 1989; Rolán \& Espinosa 1994; Redfern 2013). However, I. peetersae is differentiated by a somewhat bottle-shaped shell, the presence of three spiral cords through most of the protoconch, a late median spiral cord of the teleoconch, the white coloration comprising the five initial whorls of the shell (but only two to three whorls in I. tricingulata, Fig. 3A-D) and a darker brown coloration in the remaining whorls.

Isotriphora tricingulata is also easily distinguished from Isotriphora onca Fernandes, Pimenta \& Leal, 2013, from the Vitória-Trindade Seamount Chain (southeastern Brazil), by the presence of an evident median spiral cord emerging in the fifth/sixth whorl (Fig. 3F), but only with a very reduced size after the $13^{\text {th }}$ whorl in $I$. onca (Fernandes et al. 2013). The shell of I. onca is more elongated, with a long and almost closed anterior canal, instead of the short and open or partly closed anterior canal of I. tricingulata (Fig. 3H)

The single difference between the holotype of I. tricingulata and shells from Brazil is the earlier emergence of the median spiral cord in the holotype (fourth whorl vs usually fifth whorl in shells from Brazil). Despite the supposed intracapsular metamorphosis suggested by protoconch morphology (Fig. 3I), different populations of this species may be connected by the stepping stones of the Lesser Antilles and the continental shelf of the Guyana.

One shell of I. tricingulata from Brazil has a late emergence of the adapical spiral cord, only at the end of the third whorl of the shell (Fig. 3J). This might be a small abnormality in the development of the initial whorls.

\section{Geographical records}

Antigua (Zhang 2011); Guadeloupe (type locality); Brazil: Amapá (this study).

\section{Bathymetric distribution}

Depth: $72 \mathrm{~m}$ (this study) to $81 \mathrm{~m}$ (type locality).

Isotriphora uncia sp. nov. urn:Isid:zoobank.org:act:2D9B275B-0251-48C5-A192-61FD1A16B0BE

Figs 4, 23H, 51

\section{Diagnosis}

Small, white shell; truncated apex; median spiral cord (or supranumerical cord) emerges in the ninth/ eleventh whorl of the shell; closed anterior canal.

\section{Etymology}

The specific name alludes to the snow leopard (Panthera uncia (Schreber, 1775)) owing to the white shell color and the habit of authors to name species of Isotriphora after big felines.

\section{Material examined}

Holotype

BRAZIL - Fernando de Noronha Archipelago • Ilha Rata; depth 12 m; 8 Jul. 1999; IBUFRJ 11165. 


\section{Other material}

BRAZIL - Fernando de Noronha Archipelago - 1 spec.; same collection data as for holotype; MNRJ 34420* • 2 specs; Baía Sueste; depth 17 m; Jan. 1979; MORG 20632* • 1 spec.; Cabeço da Sapata; depth 40 m; 5 Dec. 1985; M. Cabeda leg.; MORG 24622* • 2 specs; Cabeço da Sapata; depth 40 m; 5 Dec. 1985; M. Cabeda leg.; MORG 52610*. - Atol das Rocas • 30 specs; Ilha do Farol; Feb. 1977; MORG 19120*• 8 specs; Feb. 1977; on coral; MORG 19137*.

\section{Description}

Shell sinistral, small, cyrtoconoid or slightly ovoid, nearly rectilinear to moderately convex profile, up to $3.7 \mathrm{~mm}$ long, $1.2 \mathrm{~mm}$ wide, length/width ratio 2.4 to 3.0 up to 10.5 whorls. Protoconch paucispiral with truncated apex, without clear differentiation from teleoconch; two strongly nodulose spiral cords starting from slightly pointed and very narrow nucleus, abapical cord initially much more prominent; adapical cord usually more prominent than abapical one in the body whorl of adult shells; median spiral cord (or just supranumerical cord) emerges in ninth to eleventh whorl of shell, bordering closely adapical cord; on body whorl, spiral cords are 1.3-2.3 $\times$ as wide as the distance between them; 14-17 nearly orthocline (initial whorls) to opisthocline (late whorls), weak axial ribs at the seventh whorl of shell; rounded nodules of medium to moderately large size; distinct but very shallow suture, with small sutural cord, more evident in late whorls; thin, slightly wavy to nearly smooth subperipheral cord, not developing

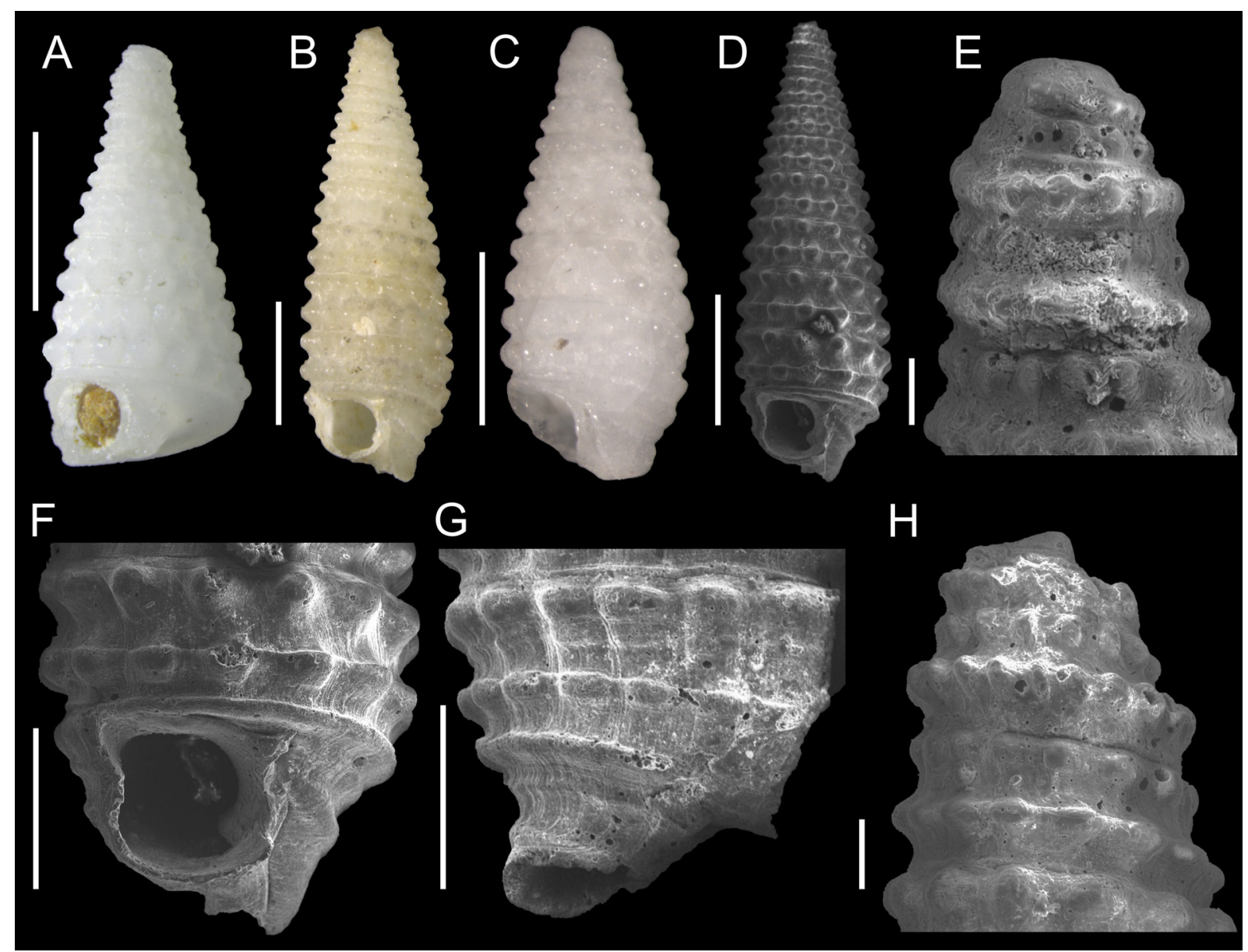

Fig. 4. Isotriphora uncia sp. nov. A. IBUFRJ 11165, holotype, $2.37 \mathrm{~mm}$. B. MORG 24622*, $3.63 \mathrm{~mm}$. C. MORG 19137*, $2.50 \mathrm{~mm}$. D, F-H. Same shell as A. E. MORG 20632*. Scale bars: A-D = $1 \mathrm{~mm} ; \mathrm{E}, \mathrm{H}=100 \mu \mathrm{m} ; \mathrm{F}-\mathrm{G}=500 \mu \mathrm{m}$. 
nodules, one to two very small and ill-defined basal cords; supranumerical cords apparently absent; small and ovate aperture, $0.54-0.62 \mathrm{~mm}$ long, $0.43-0.44 \mathrm{~mm}$ wide, length/width ratio $1.2-1.4$; anterior canal closed, medium-sized, curved backwards/downwards, $0.27-0.37 \mathrm{~mm}$ long, $0.25-0.27 \mathrm{~mm}$ wide, length/width ratio 1.1-1.3; posterior canal as somewhat deep sinus, $0.12-0.14 \mathrm{~mm}$ long, not detached from aperture. Shell white.

\section{Remarks}

This is one of the smallest triphorids in the world, with the largest adult shell herein analysed reaching only $3.7 \mathrm{~mm}$ in length. The species is abundant in Fernando de Noronha and Atol das Rocas, but shells are often much eroded, especially at the apex.

Isotriphora guanahacabibes Rolán \& Fernández-Garcés, 2008, up to now restricted to Cuba and Cayman Islands, shares similar features with I. uncia sp. nov., including the white shell and late development of the median spiral cord. In contrast, the shell of I. guanahacabibes reaches up to $5.5 \mathrm{~mm}$ in length and it is more elongated and slightly bottle-shaped (Rolán \& Fernández-Garcés 2008), instead of the short and usually slightly ovoid shell of I. uncia sp. nov. (Fig. 4C).

The median spiral cord of the teleoconch of I. uncia sp. nov. is not fully developed in shells herein analysed, appearing as a very small thread just behind the peristome (Fig. 4G), which raises the hypothesis of it to be merely a supranumerical cord. However, other species of Isotriphora also show a very late development of this median spiral cord (Rolán \& Fernández-Garcés 2008; Fernandes et al. 2013), suggesting that a shell of I. uncia sp. nov. attaining more whorls would reveal a gradual development of the median spiral cord.

\section{Geographical records}

Brazil: Fernando de Noronha and Atol das Rocas.

\section{Bathymetric distribution}

Depth: $12-40 \mathrm{~m}$.

Isotriphora leo $\mathrm{sp}$. nov. urn:1sid:zoobank.org:act:D7BFF5C6-9436-4BA3-BE0F-8551DCB43F8A

Figs 5, 23D, 52

\section{Diagnosis}

Small shell with a truncated apex; late adapical spiral cord, emerging in the third whorl of shell; white color, but light brown in the adapical spiral, subperipheral and adapical basal cords.

\section{Etymology}

The specific name alludes to the lion (Panthera leo (Linnaeus, 1758)) owing to the habit of authors to name species of Isotriphora after big felines.

\section{Material examined}

\section{Holotype}

BRAZIL - Trindade Island • Beberibe; depth 4-6 m; Barcellos and Laurino leg.; MNRJ 29392*. 


\section{Other material}

BRAZIL - Trindade Island - 1 spec.; same collection data as for holotype; Barcellos and Laurino leg.; MORG 25615* • 2 specs; Fundeadouro; depth 15 m; 15 Sep. 1987; Barcellos and Laurino leg.; MORG 25645*.

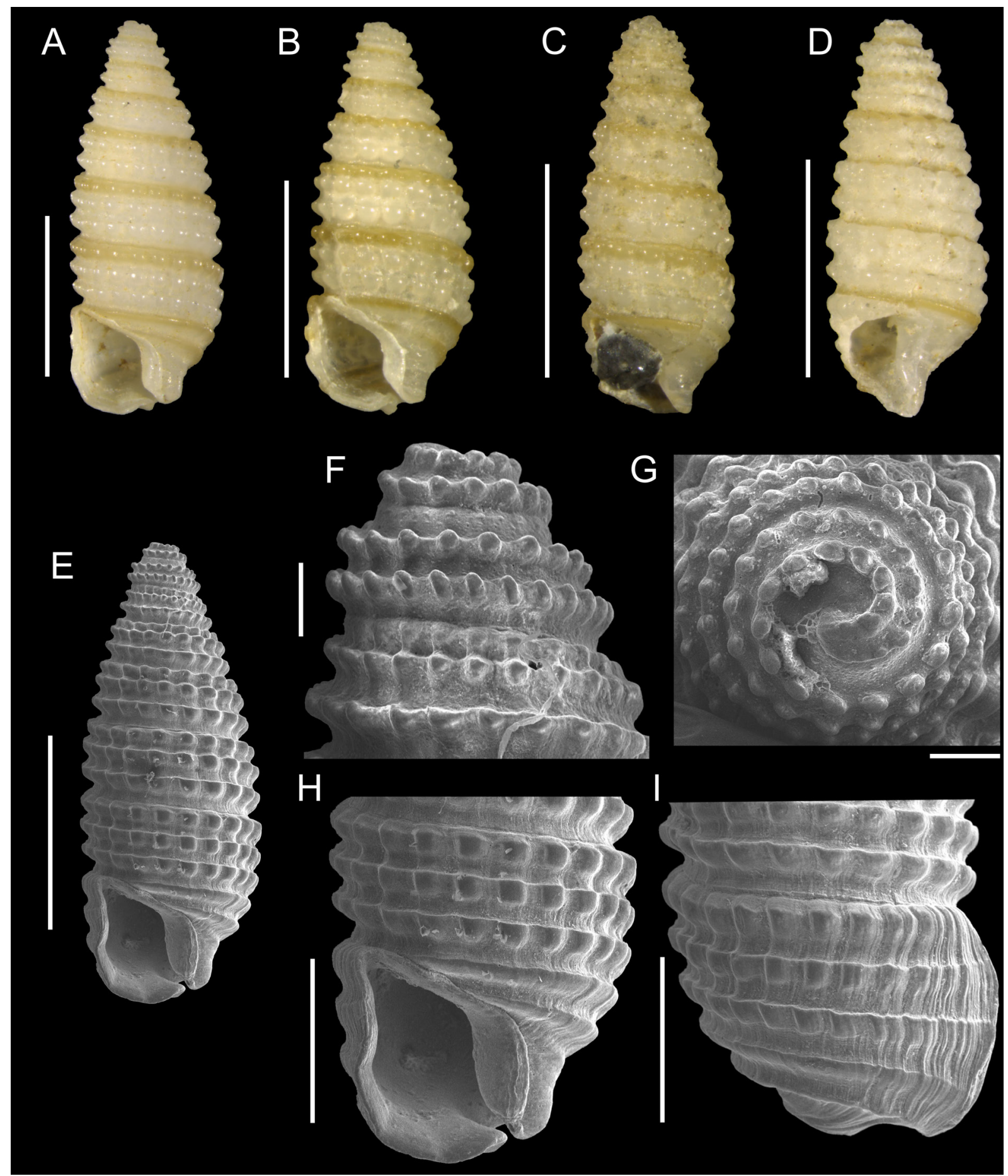

Fig. 5. Isotriphora leo sp. nov. A. MNRJ 29392*, holotype, $2.39 \mathrm{~mm}$. B. MORG 25615*, $2.00 \mathrm{~mm}$. C-D. MORG 25645*, $1.76 \mathrm{~mm}$ and $1.79 \mathrm{~mm}$, respectively. E-I. HolotypE. Scale bars: A-E = $1 \mathrm{~mm} ; \mathrm{F}-\mathrm{G}=100 \mu \mathrm{m} ; \mathrm{H}-\mathrm{I}=500 \mu \mathrm{m}$. 


\section{Description}

Shell sinistral, small, cyrtoconoid to ovoid, slightly convex profile, up to $2.4 \mathrm{~mm}$ long, $0.9 \mathrm{~mm}$ wide, length/width ratio 2.4 to 2.5 , up to 7.5 whorls. Protoconch paucispiral with truncated apex, without clear differentiation from teleoconch; two strongly nodulose spiral cords (median and abapical) of equal size starting from slightly pointed and very narrow nucleus, respectively situated at $\sim 34 \%$ and $\sim 71 \%$ of whorl height; third (adapical) spiral cord evident since third whorl of shell, bordering median cord and reaching same size of other cords after 1.5 to two whorls, being usually slightly more prominent than others on body whorl; on body whorl, spiral cords are 1.0-1.2 $\times$ as wide as distance between them; 1720 axial ribs at sixth whorl of shell, with varying arrangement, often orthocline, but slightly prosocline or slightly opisthocline in some whorls of certain shells; rounded nodules of medium to moderately large size; distinct and well-developed suture, with small sutural cord; smooth subperipheral and basal cords, abapical one very reduced, even indistinct in some shells; supranumerical cords absent; ovate to elliptical aperture, $0.34-0.57 \mathrm{~mm}$ long, $0.31-0.43 \mathrm{~mm}$ wide, length/width ratio $1.1-1.4$; anterior canal very short, open, $0.08-0.14 \mathrm{~mm}$ long, $0.13-0.14 \mathrm{~mm}$ wide, length/width ratio $0.6-1.0$; posterior canal as acute sinus, $0.07-0.12 \mathrm{~mm}$ long, not detached from aperture. Shell white, but light brown in the adapical spiral, subperipheral and adapical basal cords.

\section{Remarks}

This species is unique in Isotriphora by the late emergence of the adapical spiral cord of the teleoconch (Fig. 5E-F), thus raising doubts about the generic allocation. In fact, the shell of Isotriphora leo sp. nov. is very similar to that of some species of the family Cerithiopsidae in shape, small size and the late development of the adapical spiral cord, constituting an example of convergence in Triphoroidea.

The late emergence of the adapical spiral cord distinguishes I. leo sp. nov. from the also small and slightly ovoid shell of I. uncia sp. nov. from Fernando de Noronha and Atol das Rocas, and the similarly colored shell of Isotriphora tigrina Fernandes, Pimenta \& Leal, 2013 from the Vitória-Trindade Chain. Isotriphora leo sp. nov. probably is restricted to the shallow waters of Trindade Island, as it was not sampled in deeper waters of the Vitória-Trindade Chain by expeditions MD55 and REVIZEECentral (Fernandes et al. 2013).

\section{Geographical records}

Brazil: Trindade Island.

\section{Bathymetric distribution}

Depth: 4-15 m.

\section{Isotriphora $\mathrm{sp} .1$}

Figs 6, 23I, 52

\section{Material examined}

BRAZIL - Fernando de Noronha Archipelago • 2 specs; Cabeço da Sapata; depth 40 m; 5 Dec. 1985; M. Cabeda leg.; MORG 52611* • 2 specs; Cabeço da Sapata; 0352'41" S, 32²9'04" W; depth 45 m;

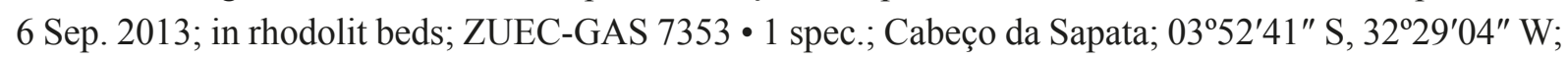
depth 45 m; 6 Sep. 2013; in rhodolit beds; ZUEC-GAS 7489. 


\section{Remarks}

The incomplete shells of Isotriphora sp. 1 are easily differentiated from those of the sympatric I. uncia sp. nov. by the presence of brown axial patches (Fig. 6A-B, E-F) and an earlier emergence of the median spiral cord, rapidly enlarging and reaching the same size of other cords (Fig. 6C). The most similar species to Isotriphora sp. 1 is "Inella" maculata Fernandes \& Pimenta, 2019, from southeastern Brazil, which has a different protoconch. Complete shells of Isotriphora sp. 1 are required to formally describe this species.

\section{Geographical distribution}

Brazil: Fernando de Noronha.

\section{Bathymetric distribution}

Depth: $40-45 \mathrm{~m}$.

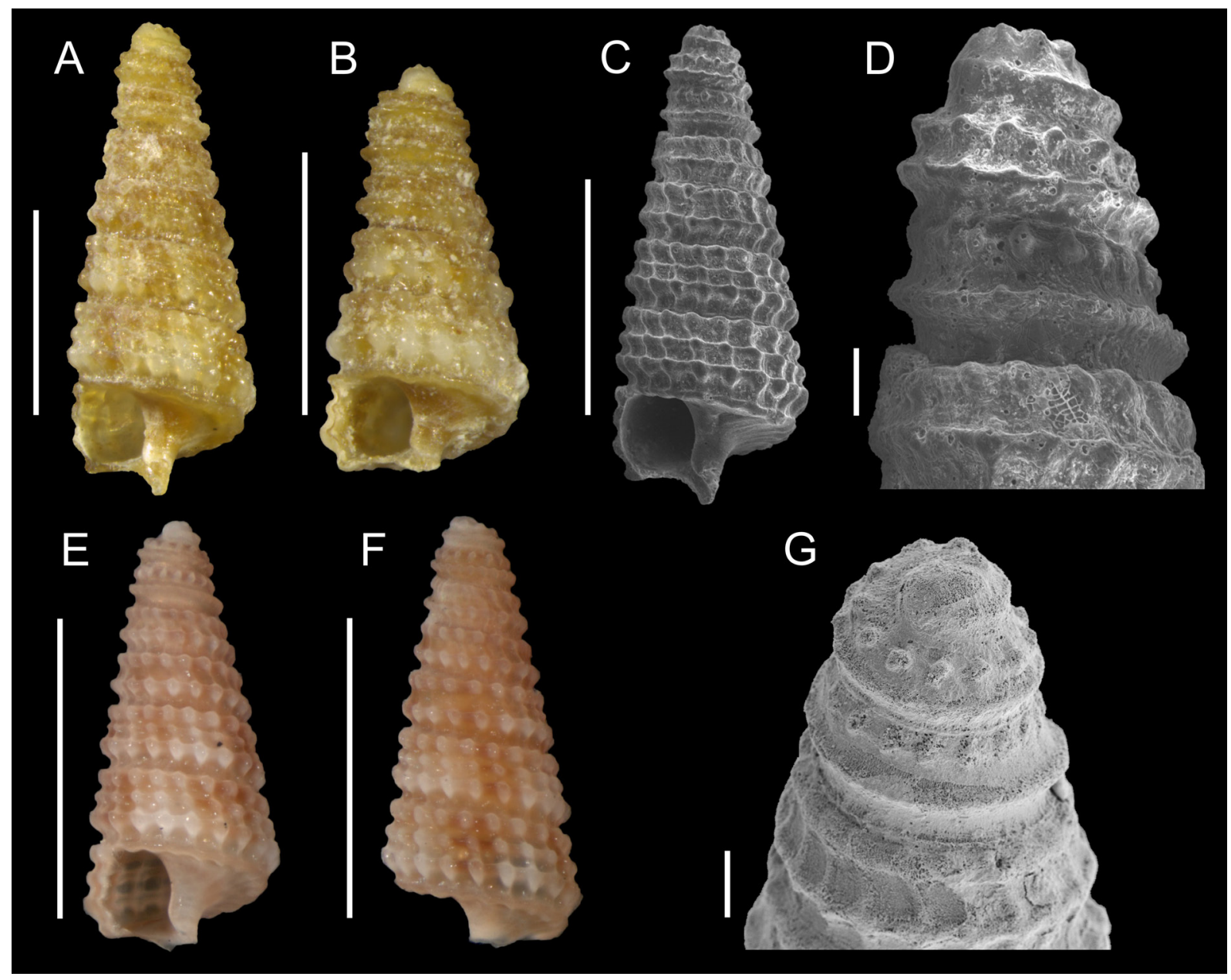

Fig. 6. Isotriphora sp. 1. A-B. MORG 52611*, $2.08 \mathrm{~mm}$ and $1.58 \mathrm{~mm}$, respectively. C-D. Same shell as A. E-F. ZUEC-GAS 7489, $1.44 \mathrm{~mm}$. G. ZUEC-GAS 7489, same shell as E. Scale bars: A-C, E-F = $1 \mathrm{~mm} ; \mathrm{D}, \mathrm{G}=100 \mu \mathrm{m}$. Photo credits E-G: Aramys Cesar (UNICAMP). 
Genus Marshallora Bouchet, 1985

\section{Type species}

Murex adversus Montagu, 1803. Original designation. Recent, northeastern Atlantic and Mediterranean.

\section{Marshallora ostenta Rolán \& Fernández-Garcés, 2008}

Figs $7-8,23 \mathrm{~L}, 54,83$

Marshallora ostenta Rolán \& Fernández-Garcés, 2008: 94, figs 7A-N, 8E-F.

Marshallora ostenta - Lee 2009: 89.

\section{Material examined}

\section{Holotype}

CUBA • Cienfuegos Bay; MNCN 15.05/47055.

\section{Paratypes}

See Rolán \& Fernández-Garcés (2008).

\section{Other material}

BRAZIL - North Brazil • 11 specs; REVIZEE-Norte III st. 176; UFMA* • 1 spec.; REVIZEE-Norte III st. 192; UFMA*. - Amapá • 1 spec.; 0358'43" N, 49³3'24" W; 2001; MNRJ 32570* • 1 spec.; AMASSEDS st. 4134; MORG 43335 • 1 spec.; AMASSEDS st. 3210; MNRJ 33801*. - Rio Grande do Norte • 1 spec.; BPot 1-MR31; MNRJ 31536* 1 spec.; BPot 1-MR41; MNRJ 31538* 1 spec.; BPot 2-MR32; MNRJ 31657* 2 specs; BPot 2-MR41; MNRJ 31540* 1 spec.; BPot 2-MR45; MNRJ 31541*. - Sergipe • 1 spec.; Petro/UFS st. E5-A1; with soft part preservation; UFS • 1 spec.; Petro/UFS st. 15.3; UFS • 1 spec.; Petro/UFS st. 18.1; UFS. - Bahia 4 specs; Baía de Todos os Santos; May 1997; MNRJ 34430* • 1 spec.; Parcel Paredes, Alcobaça; depth 0-3 m; 8 Jan. 2000; P.J. Souza and E. Gonçalves leg.; MZSP 56305*. - Espírito Santo • 1 spec.; REVIZEE-Central C1-VV24; MORG 40378 - 2 specs; REVIZEE-Central C1-VV24; MORG 52253 • 3 specs; REVIZEE-Central C1-VV31; IBUFRJ 19484 • 1 spec.; REVIZEE-Central C1-C65; MORG 39090* • $1 \mathrm{spec}$; 19²5'08" S,

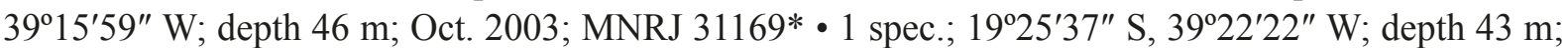
Oct. 2003; MNRJ 30750* • 1 spec.; REVIZEE-Central C1-VV38; IBUFRJ 19614 • 1 spec.; REVIZEECentral C6-R2\#1-1; IBUFRJ $19506 \bullet 1$ spec.; 20¹4' S, 40¹2' W; Jun. 2008; MNRJ 32659* 1 spec.; $20^{\circ} 42^{\prime} 00^{\prime \prime}$ S, 402 $24^{\prime 2} 8^{\prime \prime}$ W, Ilha Escalvada; depth 10-15 m; Jan. 2013; W. Vieira leg.; MNRJ 34026* • 2 specs; 2042' S, 4006' W; depth 43 m; 27 Aug. 1979; IBUFRJ 19551 6 specs; 2047' S, 40³4' W; Nov. 2007; MNRJ 32412*• 1 spec.; 2047' S, 40³4' W; Sep. 2007-Oct. 2008; MNRJ 17227*• 1 spec.;

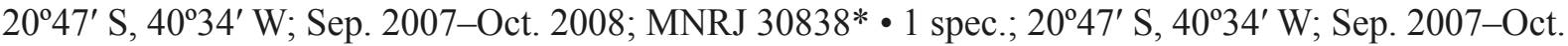
2008; MNRJ 31017* • 1 spec.; 2047' S, 40³4' W; Sep. 2007-Oct. 2008; MNRJ 31029* • 1 spec.; $20^{\circ} 47^{\prime} \mathrm{S}, 40^{\circ} 34^{\prime} \mathrm{W}$; Sep. 2007-Oct. 2008; MNRJ 31139* - 1 spec.; $20^{\circ} 47^{\prime} \mathrm{S}, 40^{\circ} 34^{\prime} \mathrm{W}$; Mar. 2010;

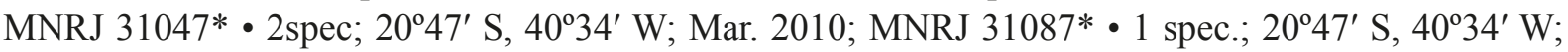
Mar. 2010; MNRJ 31092* - Rio de Janeiro • 2 specs; HAB 13-H2; MNRJ 18588* • 1 spec.; HAB 16G1; MNRJ 18623*• 1 spec.; REVIZEE-Central C1-D1-2; IBUFRJ $19532 \bullet 1$ spec.; REVIZEE-Central C1-D3; IBUFRJ 12881.

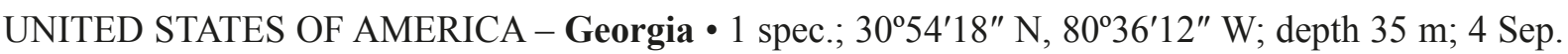
1980; R/V Bagby leg.; with soft part preservation; USNM 848771. 




Fig. 7. Marshallora ostenta Rolán \& Fernández-Garcés, 2008. A-E. From "Caribbean". A. MNCN 15.05/47055, holotype, $4.20 \mathrm{~mm}$. B-C. BMSM 15206, paratypes, $5.55 \mathrm{~mm}$ and $5.65 \mathrm{~mm}$, respectively. D. USNM 1112660, paratype, $3.64 \mathrm{~mm}$. E. FLMNH 419187, paratype, $3.71 \mathrm{~mm}$. F-S. From Brazil. F. MNRJ 33801*, $2.42 \mathrm{~mm}$. G. MORG 39090*, $4.00 \mathrm{~mm}$. H-I. MNRJ 32412*, $3.03 \mathrm{~mm}$ and $3.07 \mathrm{~mm}$, respectively. J. MNRJ 30750*, $3.61 \mathrm{~mm}$. K. MNRJ 31017*, $2.50 \mathrm{~mm}$. L. MNRJ 17227*, $4.40 \mathrm{~mm}$. M. MNRJ 18588*, $3.34 \mathrm{~mm}$. N-O. IBUFRJ 19532, $3.07 \mathrm{~mm}$. P. MNRJ 31012*, $4.12 \mathrm{~mm}$. Q. MNRJ 31087*, $3.91 \mathrm{~mm}$. R. MNRJ 32659*, $3.91 \mathrm{~mm}$. S. MNRJ 34026*, $2.65 \mathrm{~mm}$. Scale bars: $1 \mathrm{~mm}$. 


\section{Description}

Shell sinistral, elongated, cyrtoconoid to slightly ovoid, moderately convex profile, up to $4.4 \mathrm{~mm}$ long, $1.4 \mathrm{~mm}$ wide, length/width ratio 2.4 to 3.4. Protoconch multispiral, conical, $0.47-0.55 \mathrm{~mm}$ long, 0.40 $0.45 \mathrm{~mm}$ wide, $4.75-5.25$ convex whorls; embryonic shell dome-shaped, covered by small granules in its abapical portion; larval shell with two spiral cords strengthening through first whorl, soon becoming distinct, but adapical one disappears about one whorl after its emergence or as late as at last whorl; adapical cord can be much weaker than abapical one; cords respectively situated at $\sim 39 \%$ and $60 \%-69 \%$ of penultimate whorl height; $\sim 27$ nearly rectilinear to slightly sigmoid axial ribs. Teleoconch with up to

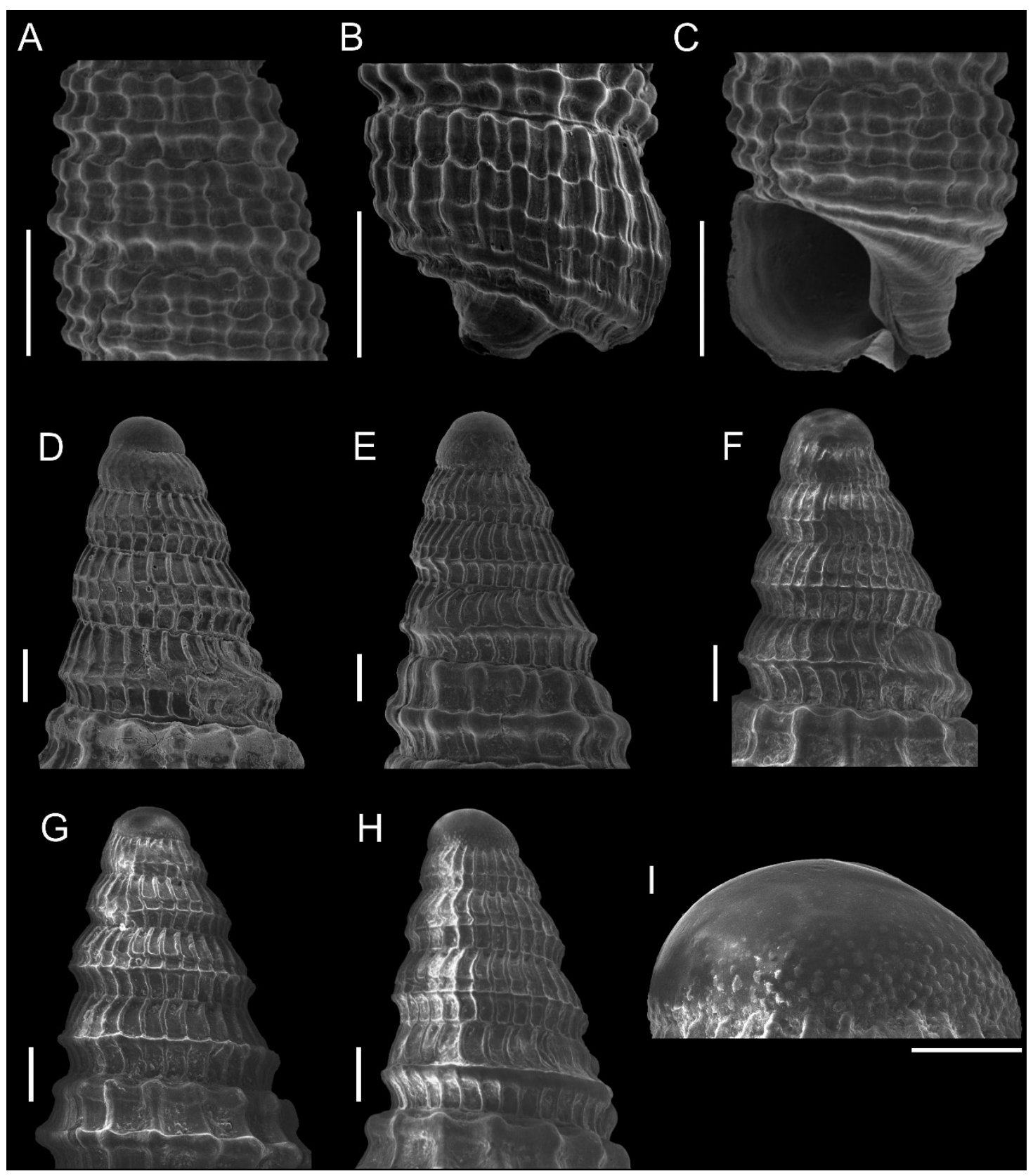

Fig. 8. Marshallora ostenta Rolán \& Fernández-Garcés, 2008 from Brazil. A-C, E. IBUFRJ 19532, same shell as Fig. 7N. D. MNRJ 18623*. F. MNRJ 31017*, same shell as Fig. 7K. G. MNRJ 33801*, same shell as Fig. 7F. H-I. MNRJ 30750*, same shell as Fig. 7J. Scale bars: A-C $=500 \mu \mathrm{m}$; D-H $=$ $100 \mu \mathrm{m} ; \mathrm{I}=50 \mu \mathrm{m}$. 
nine whorls; two spiral cords (adapical and abapical) at beginning, abapical one continuous to that of protoconch; median spiral cord emerges in fourth or fifth whorl (rarely in sixth whorl), reaching same size as other cords after 0.5 to 1.5 whorl; on body whorl, spiral cords are $0.9-1.5 \times$ as wide as distance between them; 20-23 nearly orthocline axial ribs at fifth whorl; rounded nodules, with moderately large to medium size; suture distinct, well developed, with small sutural cord; slightly wavy to nearly smooth subperipheral cord, two smooth basal cords; no supranumerical cords; ovate aperture, $0.58-0.79 \mathrm{~mm}$ long, $0.45-0.61 \mathrm{~mm}$ wide, length/width ratio $1.2-1.3$; anterior canal short, open or partly closed by the projection of outer lip, $0.18-0.31 \mathrm{~mm}$ long, $0.17-0.25 \mathrm{~mm}$ wide, length/width ratio $0.9-1.4$; posterior canal as small sinus, $0.07-0.12 \mathrm{~mm}$ long. Protoconch light-brown to golden, embryonic shell whitish; teleoconch with faint cream to light brown background, one or two initial whorls often slightly clearer or even white.

\section{Remarks}

Rolán \& Fernández-Garcés (2008) hesitated about the taxonomic integrity of M. ostenta, which may constitute a species with a considerable conchological variation or more than one species. They warned for the chromatic variation, the emergence of the median spiral cord of the teleoconch, and the number of whorls and spiral cords of the protoconch. Differences in the size and shape of adult shells (Fig. 7) also occur. Agreeing with the previous authors, an in-depth analysis of anatomy and DNA may solve this taxonomical problem. Meanwhile, shells from Brazil are allocated under this name.

The shell illustrated by Garcia \& Lee (2011) as M. ostenta from Louisiana (southern USA) is dark and with a much rectilinear profile, not being recognized as belonging to this species. Shells from Brazil hardly ever show a slightly different coloration in the adapical spiral cord (somewhat darker or clearer) in relation to the remaining teleoconch (Fig. 7F-S), as sometimes observed in shells from the type material.

Shells of Marshallora modesta (C.B. Adams, 1850) and Marshallora nigrocincta (C.B. Adams, 1839) are darker than those of $M$. ostenta, never acquiring a white coloration in the initial whorls of the teleoconch (Rolán \& Fernández-Garcés 2008). In addition, M. ostenta is found in a wider bathymetric range than the two former species, which are mainly restricted to the littoral zone.

\section{Geographical records}

USA: Georgia (this study), Florida (Rolán \& Fernández-Garcés 2008; Lee 2009); Cuba (type locality); Brazil: Amapá, Rio Grande do Norte, Sergipe to Rio de Janeiro (this study).

\section{Bathymetric distribution}

Depth: 3-92 m (this study).

\section{Marshallora sp. 1}

Figs 9, 23M, 55

\section{Material examined}

BRAZIL - Rio de Janeiro • 2 specs; Rio das Ostras; Sep. 1971; MZSP 63331*.

\section{Description}

Shell sinistral, elongated, cyrtoconoid, slightly convex profile, up to $4.0 \mathrm{~mm}$ long, $1.2 \mathrm{~mm}$ wide, length/ width ratio 3.2. Protoconch paucispiral, slightly globose but small, 2.25-2.5 convex whorls, 0.36$0.47 \mathrm{~mm}$ long, $0.41-0.47 \mathrm{~mm}$ wide; first whorl dome-shaped and smooth, remaining whorls mainly smooth (maybe due to erosion), with one faint abapical cord or two distinct and equidistant spiral 
cords; small axial threads (or growth lines) may be present. Teleoconch with up to eight whorls; two spiral cords (adapical and abapical) at the beginning, abapical one continuous to that of the protoconch; median spiral cord emerges in the fifth whorl, reaching same size of other cords after 1.5 whorl; abapical cord initially larger, but the adapical one becoming the most prominent in abapical whorls; on the body whorl, the distance between spiral cords is $1.2 \times$ higher than the width of cords; 19 nearly orthocline to
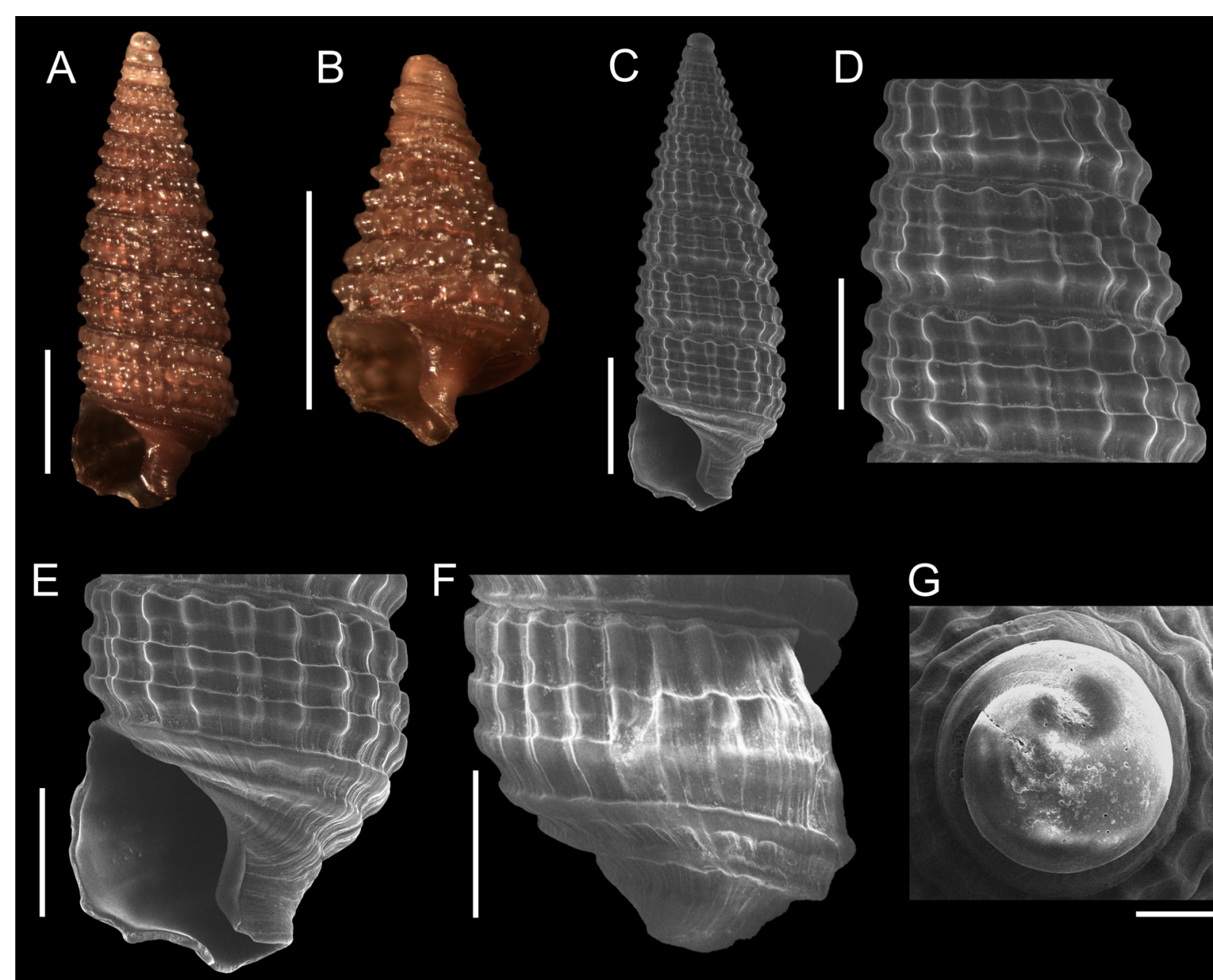

G
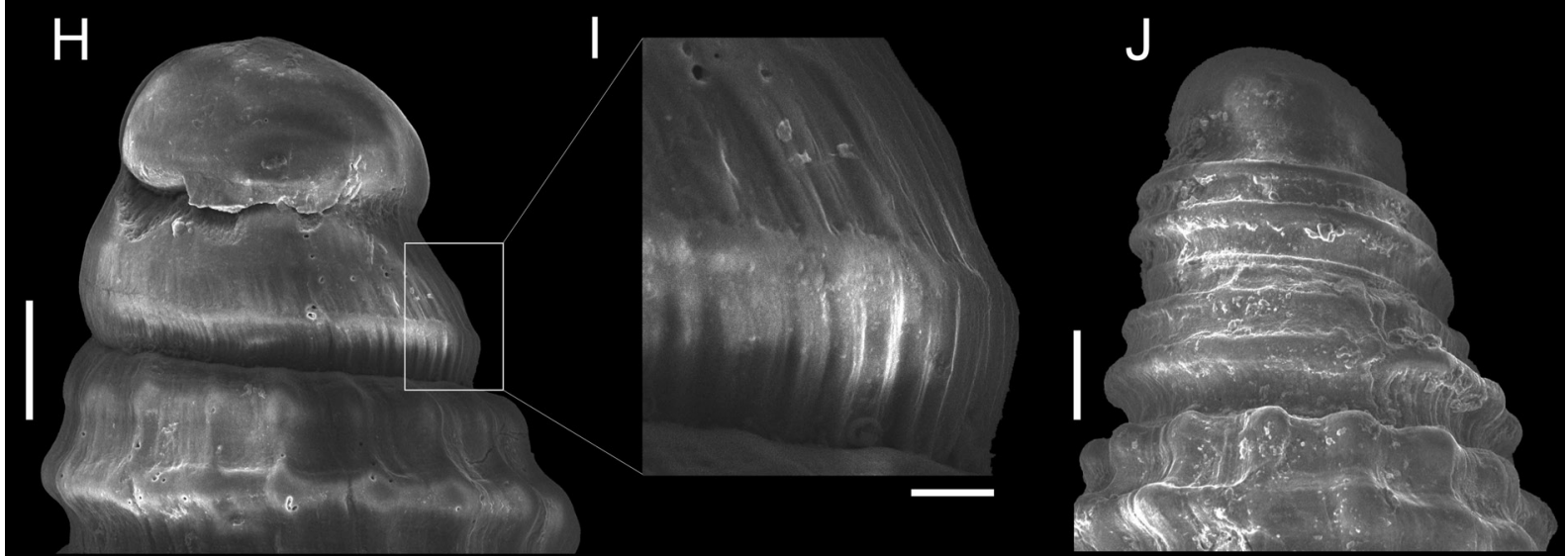

Fig. 9. Marshallora sp. 1. A-B. MZSP $63331^{*}, 4.00 \mathrm{~mm}$ and $1.65 \mathrm{~mm}$, respectively. C-I. Same shell as A. J. Same shell as B. Scale bars: A-C $=1 \mathrm{~mm}$; D-F $=500 \mu \mathrm{m}$; G-H, J = $100 \mu \mathrm{m}$; I $=20 \mu \mathrm{m}$. 
slightly opisthocline axial ribs; rounded nodules of medium size; distinct, well-developed suture, with a small sutural cord; smooth subperipheral cord, two smooth and thick basal cords; no supranumerical cords; ovate aperture, $0.69 \mathrm{~mm}$ long, $0.61 \mathrm{~mm}$ wide, length/width ratio 1.1; open, short anterior canal, $0.24 \mathrm{~mm}$ long, $0.30 \mathrm{~mm}$ wide, length/width ratio 0.8 ; posterior canal is a very small notch, $0.15 \mathrm{~mm}$ long. Brown shell.

\section{Remarks}

Marshallora sp. 1 is similar to three Caribbean species with a paucispiral protoconch, Marshallora calva (Faber \& Moolenbeek, 1991), Marshallora nicaraguensis Rolán \& Luque, 1999 and the polychromatic Marshallora nichupte Rolán \& Cruz-Ábrego, 1996. The protoconch of M. calva bears a single spiral cord (Faber \& Moolenbeek 1991; Rolán \& Fernández-Garcés 2008), but two cords appear in the juvenile shell of Marshallora sp. 1 (the protoconch of the adult shell is more similar to that of M. calva), and the brown shell of M. calva can present whitened nodules, but not in Marshallora sp. 1 (Fig. 9A-B). Marshallora nicaraguensis bears two main spiral cords in the protoconch (similar to the juvenile shell of Marshallora sp. 1), although the subperipheral and adapical basal cords are slightly nodulose and the median spiral cord of the teleoconch emerges in the third/fourth whorl (Rolán \& Luque 1999), but in the fifth whorl in Marshallora sp. 1 (Fig. 9C). Marshallora nichupte has a smooth protoconch and the median spiral cord of the teleoconch emerging in the second to the fourth whorl (Rolán \& Cruz-Ábrego 1996), also earlier than in Marshallora sp. 1. Despite the similarities with those species, the absence of any other record of a lecithotrophic species of Marshallora in Brazil after the examination of thousands of lots suggests that a change to lecithotrophy occurred in an ancestral planctotrophic population in southeastern Brazil.

\section{Geographical records}

Brazil: Rio de Janeiro.

\section{Bathymetric distribution}

Only known from beach drift.

Genus Monophorus Grillo, 1877

\section{Type species}

Trochus perversus Linnaeus, 1758. Designation by monotypy. Recent, northeastern Atlantic and Mediterranean.

Monophorus caracca (Dall, 1927) comb. nov.

Figs 10, 23N, 57

Triphora (Biforina) caracca Dall, 1927: 92.

“Triphora” caracca - Rolán \& Fernández-Garcés 2008: 140, fig. 24a-e.

\section{Material examined}

\section{Lectotype}

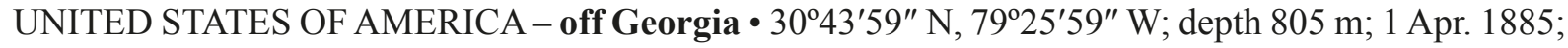

R/V Albatross leg.; USNM 108343. Two paralectotypes are also found under the same lot number.

\section{Other material}

BRAZIL - off Espírito Santo • 4 specs; MD55 st. 42-DC75; MNHN*. 


\section{Description}

Shell sinistral, elongated, conical, rectilinear profile, the better-preserved shell is $5.7 \mathrm{~mm}$ long, $1.5 \mathrm{~mm}$ wide, although complete adult shells may be much larger. Protoconch multispiral but partially broken; penultimate whorl with cruciform granules spirally disposed; last whorl with two spiral cords, situated at $\sim 31 \%$ and $\sim 62 \%$ of whorl height, crossed by weak axial ribs, despite a smooth spiral zone (i.e., without axial sculpture) just above the adapical spiral cord; prosocline (below suture) to opisthocline (below adapical cord) axial ribs. Teleoconch with up to 14 whorls; two spiral cords (adapical and abapical) at

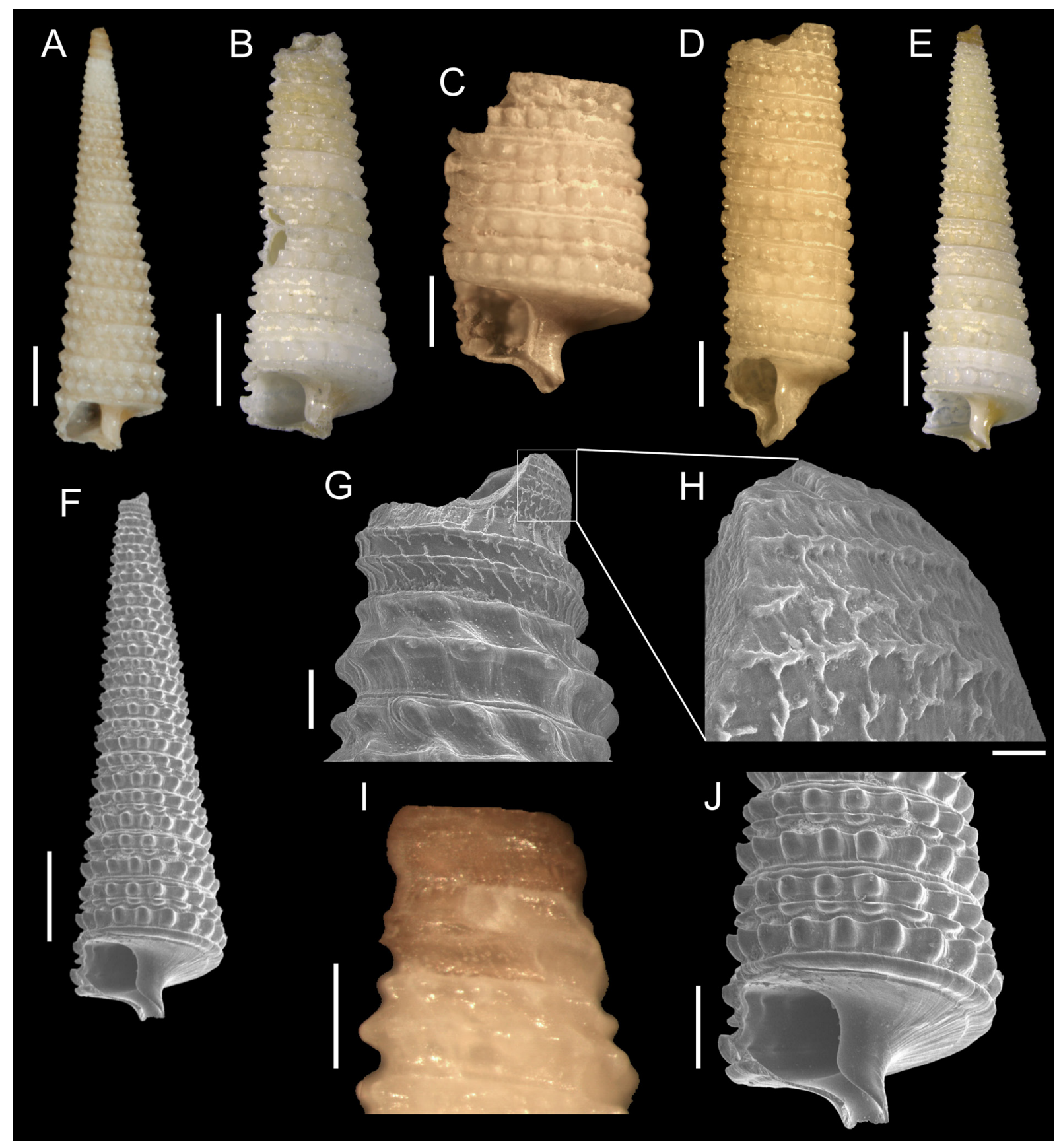

Fig. 10. Monophorus caracca (Dall, 1927) comb. nov. A. USNM 108343, lectotype, $7.1 \mathrm{~mm}$. B-E. MNHN*, $4.42 \mathrm{~mm}, 6.84 \mathrm{~mm}, 4.50 \mathrm{~mm}$ and $5.74 \mathrm{~mm}$, respectively. F-J. Same shell as E. Scale bars: A-F $=1 \mathrm{~mm} ; \mathrm{G}=100 \mu \mathrm{m} ; \mathrm{H}=20 \mu \mathrm{m} ; \mathrm{I}=250 \mu \mathrm{m} ; \mathrm{J}=500 \mu \mathrm{m}$. 
beginning, abapical one continuous to that of protoconch; median spiral cord emerges very weakly in sixth/seventh whorl, much close to adapical cord, gradually strengthening but not reaching same size of other cords even after eight whorls; in late whorls, the spiral cords are 2.0-3.5 $\times$ as wide as distance between them; 16 opisthocline axial ribs; rounded to elliptical nodules of medium size, pointed profile, keeled-shaped, especially in abapical cord; median spiral cord initially wavy, acquiring nodules after many whorls; distinct but somewhat shallow suture, with small sutural cord that gradually strengthens and becomes thick in late whorls; additional spiral cord emerges in very late whorls, immediately above adapical spiral cord; thick, smooth subperipheral cord, one thin and smooth basal cord much close to subperipheral cord; base and canals not formed or considerably damaged. Brown protoconch, white teleoconch.

\section{Remarks}

The present species shows a late median spiral cord of the teleoconch (Fig. 10J), a protoconch with cruciform granules and a smooth spiral zone (Fig. 10G), features which are also observed in Monophorus (Marshall 1983). Monophorus caracca (Dall, 1927) comb. nov. was described from the deep sea off Georgia (USA). After comparisons with the type material (Fig. 10A), the single minor difference being the median spiral cord emerging in the sixth/seventh whorl of the teleoconch in a Brazilian shell, but it emerging discreetly in the eighth whorl of the lectotype, being properly detected only in the tenth whorl (Rolán \& Fernández-Garcés 2008). In addition, the bathymetric record of the type locality is deeper than seen in Brazil (805 m and $295 \mathrm{~m}$, respectively).

Agreeing with the initial assignment of this species to the subgenus Biforina (currently a synonym of Monophorus) by Dall (1927), this species is now regarded as belonging to Monophorus. Although Dall (1927) did not explain the etymology of the specific name, 'caracca' is a word in Italian which refers to large sailboats/ships used during the Great Navigations; because it is a noun, the ending remains unaltered after the new generic allocation (ICZN 1999: article 31.2).

\section{Geographical records}

USA: off Georgia (type locality). Brazil: off Espírito Santo (this study).

\section{Bathymetric distribution}

Depth: 295 m (this study) to 805 m (type locality).

Monophorus verecundus sp. nov.

urn:1sid:zoobank.org:act:7A1A8226-038E-4623-8F73-9420F12B7848

Figs 11, 23P, 57, 83

\section{Diagnosis}

Embryonic shell covered by micro-spiral threads; larval shell initially with two spiral cords, but adapical cord disappears after 0.5 to 0.75 whorl; teleoconch with brown internodular spaces, especially in the adapical spiral cord.

\section{Etymology}

The name is derived from the Latin 'verecundus', meaning 'shy, bashful', and referring to the scarce records of this species even after an extensive revision. 


\section{Material examined}

Holotype

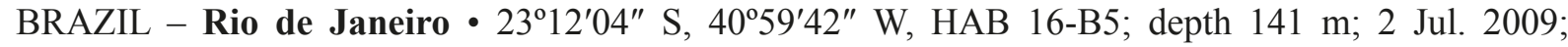
MNRJ 18383*.

Other material

BRAZIL - Rio Grande do Norte • 1 spec.; 04 44'53" S, 36 $25^{\prime} 27^{\prime \prime}$ W; depth 102-108 m; 23 May 2011; MNRJ 35114*. - Rio de Janeiro • 1 spec.; 22 $42^{\prime}$ S, 40 40' W; depth 110-120 m; 11 Apr. 2003; MNRJ 19479*. - São Paulo•1 spec.; PADCT st. 6577; MNRJ 27843*.

\section{Description}

Shell sinistral, elongated, cyrtoconoid, slightly convex profile, up to $5.4 \mathrm{~mm}$ long, $1.4 \mathrm{~mm}$ wide, length/ width ratio 3.3 to 4.0. Protoconch multispiral, conical/columnar, 4.5-5 keeled-shaped whorls, 0.49$0.52 \mathrm{~mm}$ long, $0.37-0.40 \mathrm{~mm}$ wide; embryonic shell dome-shaped, covered by about 10-12 micro-spiral threads, each composed of granules usually with somewhat pointed profile; larval shell initially with two spiral cords, but adapical cord disappears after 0.5 to 0.75 whorl, remaining abapical cord extends to end of protoconch, situated at $\sim 46 \%-53 \%$ of last whorl height; $\sim 27$ slightly sigmoid axial ribs. Teleoconch with up to 11 whorls; two spiral cords (adapical and abapical) at beginning, abapical one continuous to that of protoconch, adapical cord can be slightly larger than abapical one in early whorls; median spiral cord emerges at beginning of third to beginning of fifth whorl, reaching same size of other cords after two to 2.5 whorls; on body whorl, distance between spiral cords is equal or up to $1.2 \times$ higher than width of cords; $17-19$ nearly orthocline axial ribs; rounded to elliptical (especially in median and abapical spiral cords) nodules of medium size; distinct, well-developed suture, with small sutural cord; subperipheral and adapical basal cords narrow and nodulose, wavy abapical basal cord; two apparent supranumerical cords emerge near peristome, one between median and abapical spiral cords, the other between abapical and subperipheral cords; ovate aperture, $0.70 \mathrm{~mm}$ long, $0.49 \mathrm{~mm}$ wide, length/width ratio 1.4; partly closed anterior canal, crossed in its base by projection of outer lip, $0.26 \mathrm{~mm}$ long, $0.21 \mathrm{~mm}$ wide, length/ width ratio 1.2; deep posterior canal, up to $0.29 \mathrm{~mm}$ long, almost detached from aperture. Light brown protoconch; teleoconch with cream background, brown internodular spaces, especially in adapical spiral cord and in abapical whorls; whitened nodules.

\section{Remarks}

This species has a color pattern similar to that of Similiphora intermedia (C.B. Adams, 1850), but it is mainly distinguished by a protoconch with fewer whorls ( 4.5 to 5 whorls, Fig. 11I, vs $\sim 6$ whorls in S. intermedia), the embryonic shell covered by micro-spiral threads (Fig. 11J-K, instead of granules in S. intermedia), larval shell with one main spiral cord (Fig. 11I, but two cords in S. intermedia), and a different transition protoconch/teleoconch. Another species with a similar color pattern is Triphora scylla Fernandes \& Pimenta, 2015, but T. scylla is somewhat darker, possessing a larval shell with two spiral cords, a late median spiral cord of the teleoconch, and thicker subperipheral and basal cords (Fernandes \& Pimenta 2015).

The micro-spiral threads in the embryonic shell of M. verecundus sp. nov. (Fig. 11J-K) are similar to the cruciform granules often observed in this genus. Even though Monophorus is usually described as having two spiral cords in the larval shell (e.g., Marshall 1983), the type species Monophorus perversus shows a variation of one to two spiral cords (Bouchet 1985), thus not being an impediment to the present generic allocation. 


\section{Geographical records}

Brazil: Rio Grande do Norte, Rio de Janeiro, São Paulo.

\section{Bathymetric distribution}

Depth: $102-141 \mathrm{~m}$.
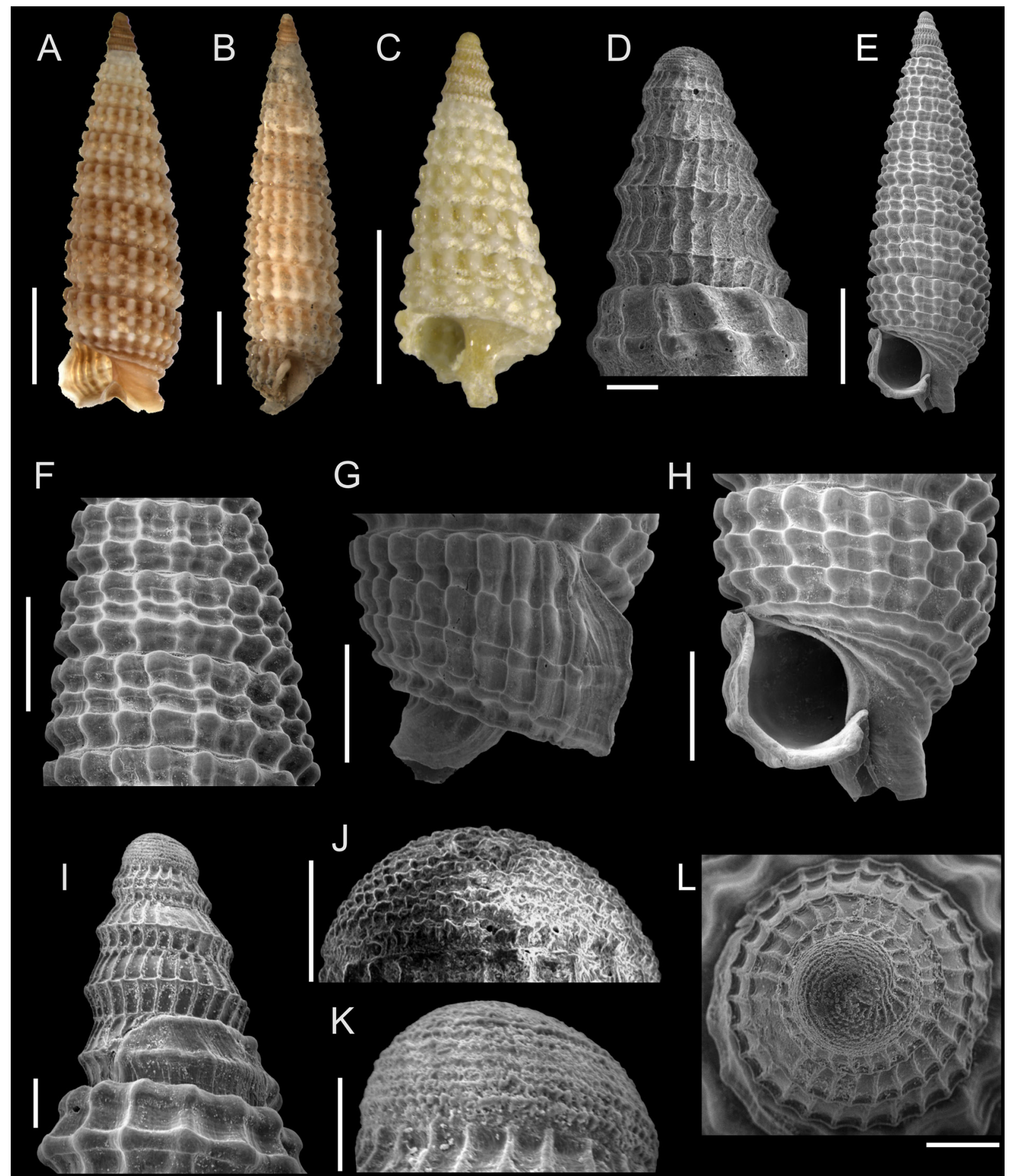

Fig. 11. Monophorus verecundus sp. nov. A. MNRJ 18383*, holotype, $4.24 \mathrm{~mm}$. B. MNRJ 19479*, $5.40 \mathrm{~mm}$. C. MNRJ 35114*, $2.47 \mathrm{~mm}$. D, J. Same shell as C. E-I, K-L. Holotype. Scale bars: A-C, E = $1 \mathrm{~mm} ; \mathrm{D}, \mathrm{I}, \mathrm{L}=100 \mu \mathrm{m} ; \mathrm{F}-\mathrm{H}=500 \mu \mathrm{m} ; \mathrm{J}-\mathrm{K}=50 \mu \mathrm{m}$. 
Genus Nanaphora Laseron, 1958

\section{Type species}

Nanaphora torquesa Laseron, 1958. Original designation. Recent, eastern Australia.

\section{Nanaphora sp. 1}

Figs 12, 23S, 60

\section{Material examined}

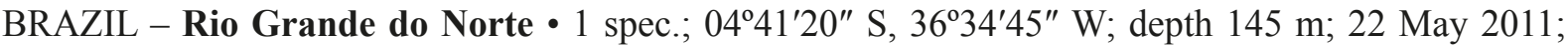
MNRJ 35177*.

\section{Description}

Shell sinistral, inflated, biconical/ovoid, convex profile, $2.9 \mathrm{~mm}$ long, $1.2 \mathrm{~mm}$ wide, length/width ratio 2.5. Protoconch multispiral, conical/columnar, $0.40 \mathrm{~mm}$ long, $0.36 \mathrm{~mm}$ wide, four convex whorls; embryonic shell dome-shaped, eroded; larval shell with two spiral cords, situated at $\sim 41 \%$ and $\sim 66 \%$ of penultimate whorl height, the adapical cord disappears in the last whorl; $\sim 28$ nearly rectilinear axial ribs. Teleoconch with 6.5 whorls; two spiral cords (adapical and abapical) at beginning, abapical one continuous to that of protoconch; median spiral cord emerges in fourth whorl, reaching same size of

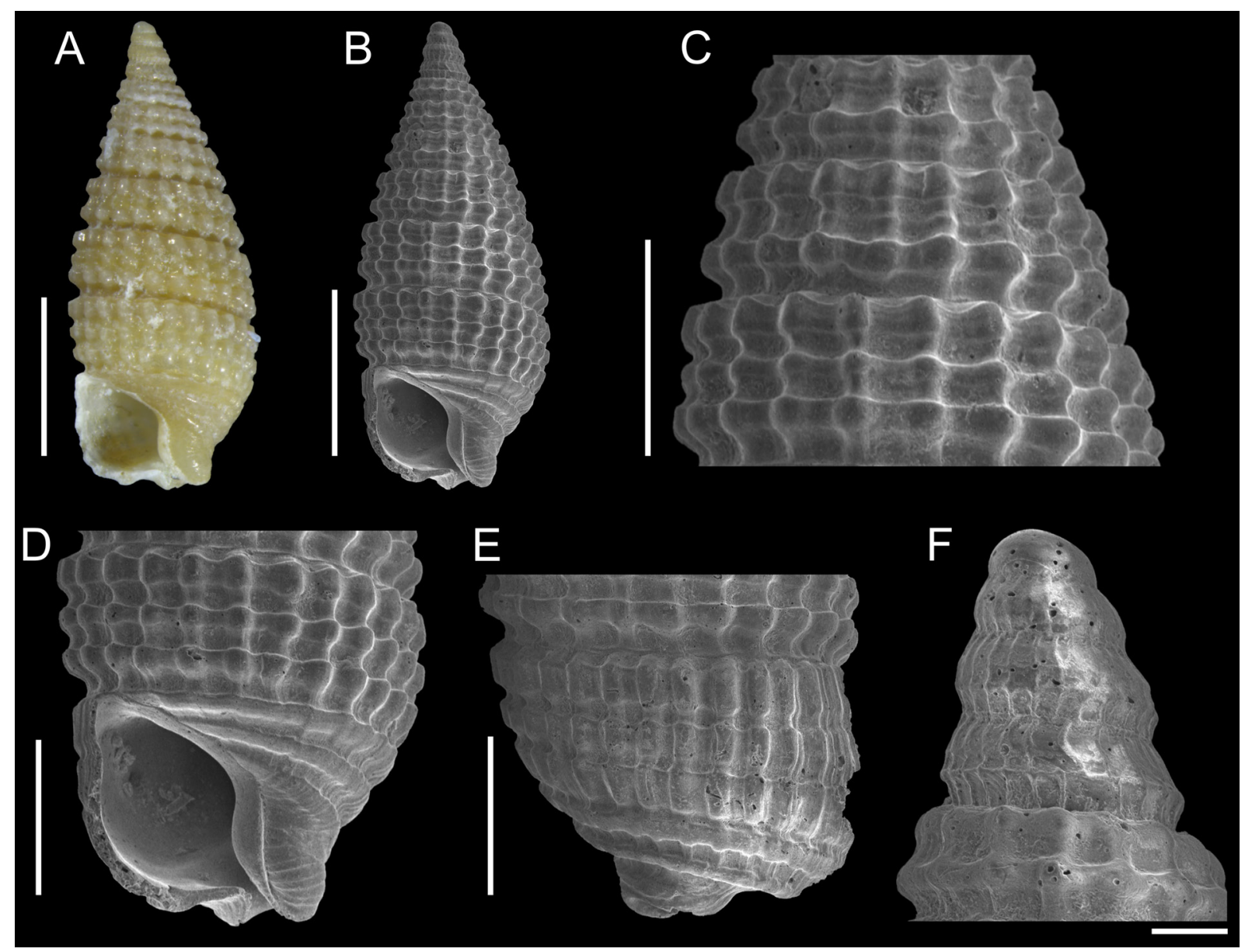

Fig. 12. Nanaphora sp. 1. A-F. MNRJ 35177*, $2.94 \mathrm{~mm}$. Scale bars: A-B $=1 \mathrm{~mm}$; C-E $=500 \mu \mathrm{m} ; \mathrm{F}=$ $100 \mu \mathrm{m}$. 
other cords after 1.5 whorl; on body whorl, spiral cords are as wide as distance between them; 24 nearly orthocline axial ribs in sixth whorl; rounded nodules of medium size; distinct suture, with very small sutural cord; wavy subperipheral cord, two nearly smooth basal cords; no supranumerical cords; elliptical aperture, $0.69 \mathrm{~mm}$ long, $0.44 \mathrm{~mm}$ wide, length/width ratio 1.5 ; anterior canal curved backwards/ downwards, short, partially open, $0.11 \mathrm{~mm}$ long, $0.22 \mathrm{~mm}$ wide, length/width ratio 0.5 ; posterior canal as small sinus, $0.08 \mathrm{~mm}$ long. Shell beige, nodules of teleoconch slightly clearer than internodular spaces.

\section{Remarks}

The most similar species to Nanaphora sp. 1 is Triphora turtlebayensis Rolán \& Lee, 2008, both sharing a distinct ovoid shell shape. However, T. turtlebayensis has a paucispiral protoconch and is restricted to Bermuda. Nanaphora sp. 1 is also superficially similar to the western Atlantic species Nanaphora verbernei (Moolenbeek \& Faber, 1989), but mainly distinguished by an earlier emergence of the median spiral cord of the teleoconch (Fig. 12B) and by the smoothness of the subperipheral and basal cords (Fig. 12D). Nanaphora sp. 1 is herein regarded as belonging to this genus especially owing to its shell shape and to the small size of its protoconch, although this species has smaller nodules of the teleoconch when compared to typical species of Nanaphora, and its embryonic shell sculpture remains unknown due to erosion.

\section{Geographical records}

Brazil: Rio Grande do Norte.

\section{Bathymetric distribution}

Only known from $145 \mathrm{~m}$ depth.

Genus Sagenotriphora Marshall, 1983

\section{Type species}

Triphora ampulla Hedley, 1903. Original designation. Recent, southwestern Pacific.

Sagenotriphora albocaput sp. nov. urn:Isid:zoobank.org:act:8BFB0B3F-052C-4299-B8D8-9E527FBC650D

Figs 13, 24B, 64

\section{Diagnosis}

Embryonic shell with irregular-shaped and vesicular granules, larval shell with two spiral cords; median spiral cord emerges in the fourth whorl of the teleoconch; protoconch white, teleoconch cream to goldenbrown.

\section{Etymology}

The specific name is derived fom the Latin 'albus', meaning 'white, clear' and 'caput', meaning 'summit', and referring to its white shell apex.

\section{Material examined}

\section{Holotype}

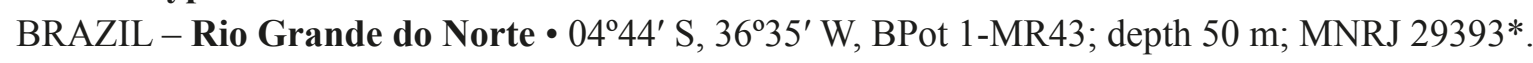




\section{Other material}

BRAZIL - Amapá • 4 specs; 0358'43" N, 49³3'24" W; 2001; MNRJ 32568* • 3 specs; 0358'43" N,

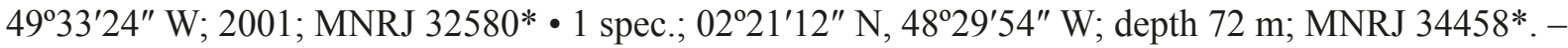
Rio Grande do Norte • 1 spec.; BPot 1-MR32; MNRJ 29394* • 4 specs; BPot 1-MR32; MNRJ 31652* • 15 specs; BPot 1-MR41; MNRJ 31586* • 5 specs; BPot 1-MR42; MNRJ 29395* 35 specs; BPot 1-MR42; MNRJ 31587* 28 specs; same collection data as for holotype; MNRJ 31588* 8 specs; BPot 1-MR44; MNRJ 31589* • 1 spec.; BPot 2-MR32; MNRJ 31656* • 4 specs; BPot 2-MR41; MNRJ 31638* - 14 specs; BPot 2-MR42; MNRJ 31636* 19 specs; BPot 2-MR44; MNRJ 31639* 7 specs; BPot 2-MR45; MNRJ 31646*. - Fernando de Noronha Archipelago • 2 specs; Jan. 1979; MORG 20634*.

\section{Description}

Shell sinistral, small, elongated, cyrtoconoid, slightly convex profile, up to $3.5 \mathrm{~mm}$ long, $1.1 \mathrm{~mm}$ wide, length/width ratio 2.7 to 3.1. Protoconch multispiral, conical, 4-4.25 whorls, $0.40-0.45 \mathrm{~mm}$ long, 0.35-0.39 mm wide; embryonic shell dome-shaped, covered by irregular, often rounded granules, and vesicular, axially-disposed granules appearing predominantly in the final and abapical portion of embryonic shell, resulting in axial ribs of the larval shell; larval shell with two spiral cords, situated at $29 \%-37 \%$ and $60 \%-65 \%$ of last whorl height; $\sim 34$ nearly rectilinear axial ribs; transition to the teleoconch defined by an often inconspicuous scar. Teleoconch with up to eight whorls; two spiral cords (adapical and abapical) at the beginning, the abapical one continuous to that of the protoconch; median spiral cord emerges in the fourth whorl (rarely at the end of the third or at the very beginning of the fifth whorl), reaching same size of abapical cord (adapical one slightly more prominent in late whorls) after 2.0 to 2.5 whorls; on the body whorl, the spiral cords are 1.1-1.8 $\times$ as wide as the distance between them; 19-21 nearly orthocline axial ribs; rounded nodules of medium size; distinct, well-developed suture, with a small sutural cord; slightly wavy to nearly smooth subperipheral cord, two smooth basal cords; three distinct supranumerical cords, one between median and abapical spiral cords, another between abapical and subperipheral cords, and a small one between subperipheral and adapical basal cords; ovate aperture, $0.51-0.60 \mathrm{~mm}$ long, $0.42-0.53 \mathrm{~mm}$ wide, length/width ratio 1.1 to 1.4 ; anterior canal moderately short, curved backwards/downwards, partly or almost closed, $0.16-0.23 \mathrm{~mm}$ long, $0.12-0.16 \mathrm{~mm}$ wide, length/width ratio 1.0-1.7; deep posterior canal, $0.12 \mathrm{~mm}$ long, not detached from aperture. White protoconch, cream to golden-brown teleoconch.

\section{Remarks}

The generic placement of this species was based on the sculpture of the embryonic shell (Fig. 13L-M), the presence of two continuous spiral cords in the larval shell (Fig. 13I-K), the smooth subperipheral and basal cords (Fig. 13H), and the presence of supranumerical cords (Fig. 13G). Although not all of them are shared with the type species Sagenotriphora ampulla (Hedley, 1903), these features are quite similar to those of Sagenotriphora osclausum (Rolán \& Fernández-Garcés, 1995) and Sagenotriphora candidula Rolán \& Lee, 2008 (Fig. 14), but S. albocaput sp. nov. is unique by having a white protoconch and a cream to golden-brown teleoconch (Fig. 13A-D). This coloration is similar to that of Isotriphora tricingulata, but the latter species has a paucispiral protoconch (Fig. 3I).

\section{Geographical records}

Brazil: Amapá, Rio Grande do Norte and Fernando de Noronha.

\section{Bathymetric distribution}

Depth: 20-72 m. 

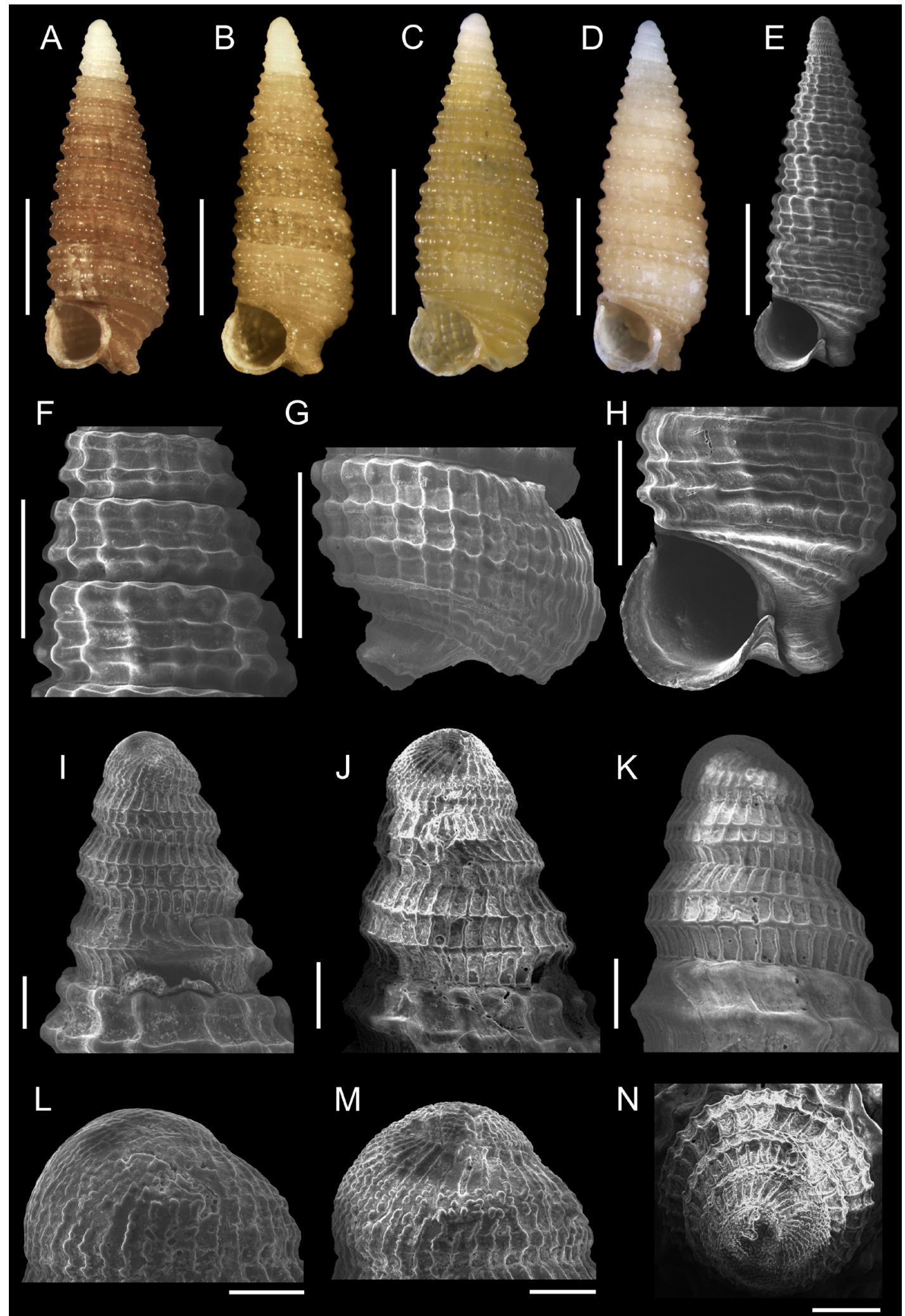

Fig. 13. Sagenotriphora albocaput sp. nov. A. MNRJ 29393*, holotype, $2.84 \mathrm{~mm}$. B. MNRJ 29394*, $3.00 \mathrm{~mm}$. C. MORG 20634*, $2.49 \mathrm{~mm}$. D. MNRJ 32580*, $2.82 \mathrm{~mm}$. E-F, H. Same shell as B. G, J, M-N. MNRJ 29395*. I, L. MNRJ 31652*. K. Same shell as D. Scale bars: A-E $=1 \mathrm{~mm}$; F-H = $500 \mu \mathrm{m} ; \mathrm{I}-\mathrm{K}, \mathrm{N}=100 \mu \mathrm{m} ; \mathrm{L}-\mathrm{M}=50 \mu \mathrm{m}$. 


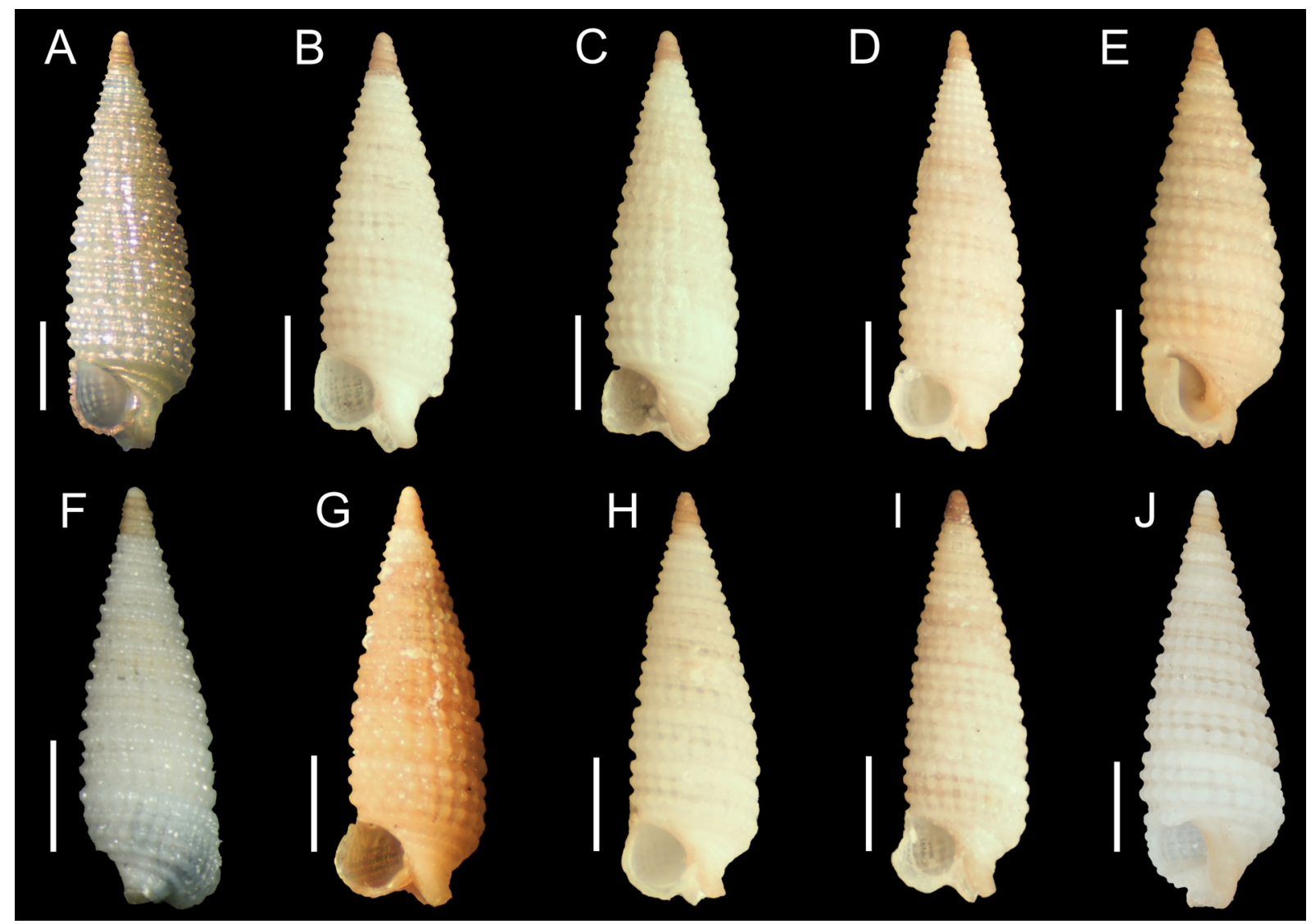

Fig. 14. Types of Sagenotriphora candidula Rolán \& Lee, 2008. A. FLMNH 419189, holotype, $5.00 \mathrm{~mm}$. B-E. FLMNH 249739, paratypes, $4.46 \mathrm{~mm}, 4.44 \mathrm{~mm}, 4.77 \mathrm{~mm}$ and $4.18 \mathrm{~mm}$, respectively. F. BMSM 15202, paratype, $3.80 \mathrm{~mm}$. G. FLMNH 178388, paratype, $4.38 \mathrm{~mm}$. H. FLMNH 154860, paratype, $4.51 \mathrm{~mm}$. I. FLMNH 127829, paratype, $4.44 \mathrm{~mm}$. J. USNM 1112659, paratype, $4.66 \mathrm{~mm}$. Scale bars: $1 \mathrm{~mm}$.

\section{Sagenotriphora sp. 1}

Figs 15, 24D, 63

\section{Material examined}

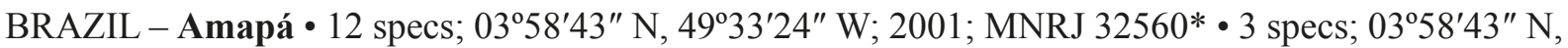

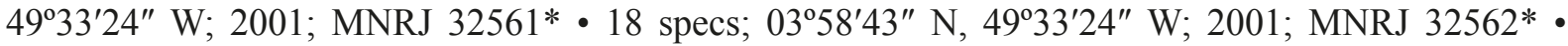
7 specs; 0358'43" N, 4933'24" W; 2001; MNRJ 32579* • 1 spec.; GEOMAR II st. 124; MNRJ 33792*

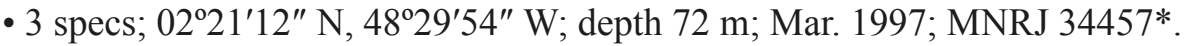

\section{Description}

Shell sinistral, elongated, cyrtoconoid, slightly convex profile in adult shells, up to $5.4 \mathrm{~mm}$ long, $1.6 \mathrm{~mm}$ wide, length/width ratio 2.9 to 3.1. Protoconch multispiral, conical, 4-4.5 convex whorls, 0.40-0.46 mm long, 0.36-0.40 mm wide; embryonic shell dome-shaped, covered by irregular-shaped granules, vesicular/axially-disposed granules appearing in the final and abapical portion of embryonic shell, resulting in axial ribs of larval shell; larval shell with two spiral cords, situated at $27 \%-29 \%$ and $\sim 60 \%-61 \%$ of last whorl height; $\sim 32$ nearly rectilinear to slightly sigmoid axial ribs. Teleoconch with up to ten whorls; two spiral cords (adapical and abapical) at beginning, abapical one continuous to that of 
protoconch; median spiral cord emerges in fourth or fifth whorl, reaching same size of other cords after 1.5-2.5 whorls; on body whorl, the spiral cords are $0.8-1.3 \times$ as wide as the distance between them; 19 20 nearly orthocline to slightly opisthocline axial ribs; rounded to slightly elliptical nodules, medium to moderately small size; distinct, well-developed suture, with small sutural cord; wavy subperipheral cord, usually not developing nodules, two thick and slightly wavy to smooth basal cords; three strong
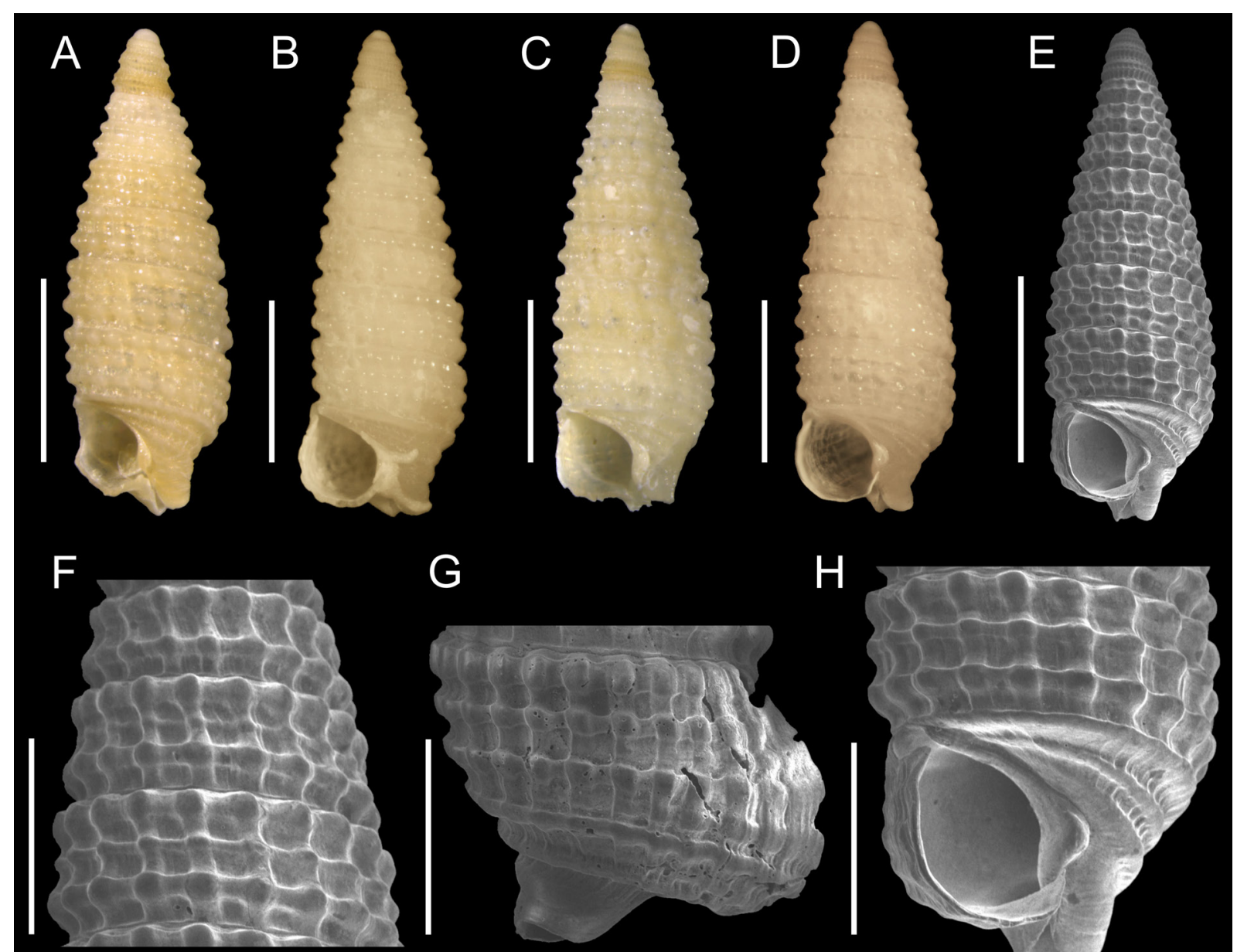

G
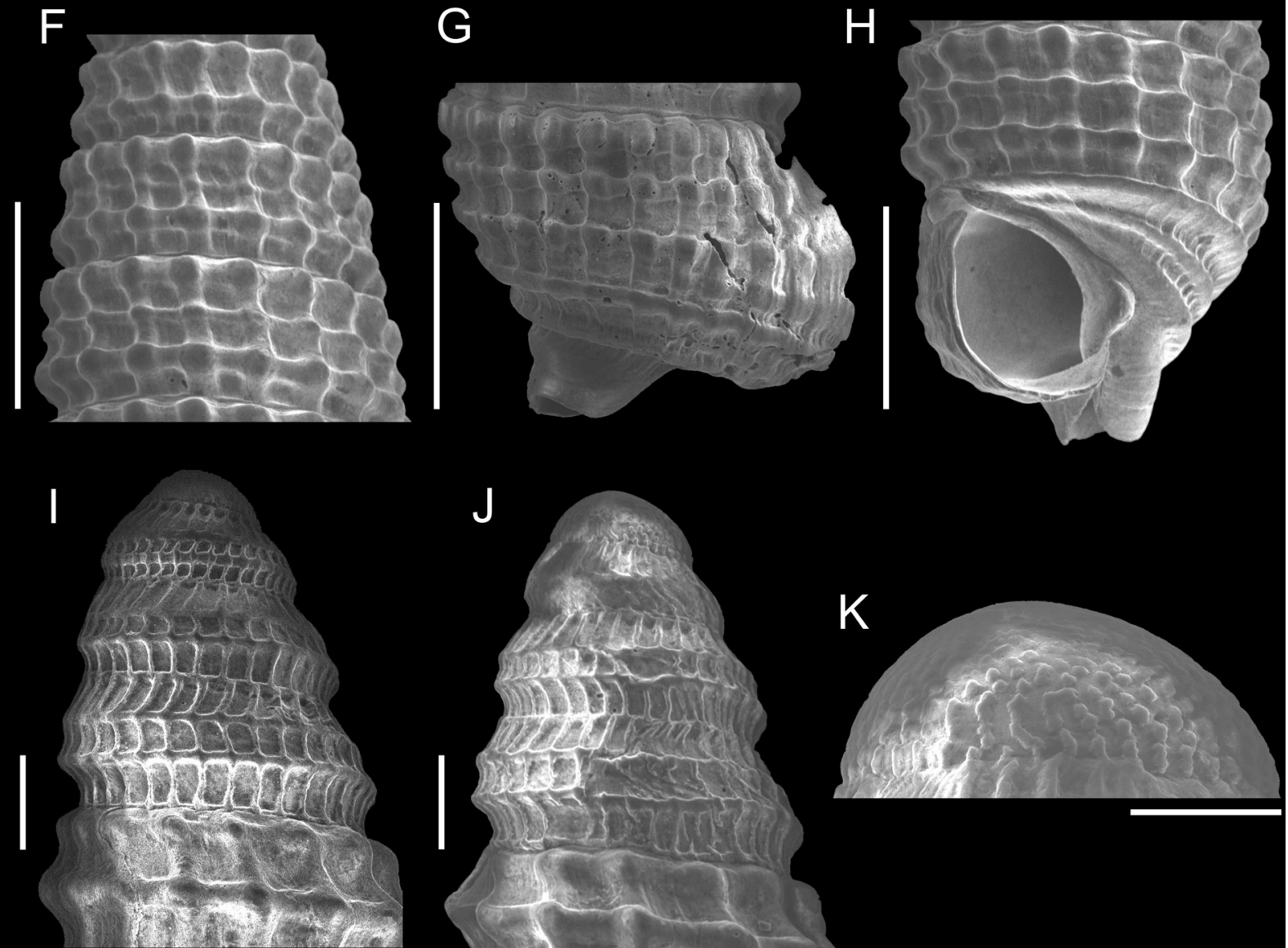

Fig. 15. Sagenotriphora sp. 1. A. MNRJ 34457*, $2.66 \mathrm{~mm}$. B. MNRJ 32560*, $2.82 \mathrm{~mm}$. C. MNRJ 32562*, $2.95 \mathrm{~mm}$. D-E. MNRJ 32579*, $2.83 \mathrm{~mm}$. F, H-I. Same shell as D. G. Same shell as B. J-K. MNRJ 32560. Scale bars: A-E $=1 \mathrm{~mm} ; \mathrm{F}-\mathrm{H}=500 \mu \mathrm{m} ; \mathrm{I}-\mathrm{J}=100 \mu \mathrm{m} ; \mathrm{K}=50 \mu \mathrm{m}$. 
supranumerical cords, one between median and abapical spiral cords, other between abapical and subperipheral cords, another between subperipheral and adapical basal cords; ovate to elliptical aperture, with slightly projected outer lip, $0.50-0.61 \mathrm{~mm}$ long, $0.33-0.48 \mathrm{~mm}$ wide, length/width ratio $1.3-1.5$; anterior canal short, curved backwards/downwards, partly or almost closed, $0.16-0.23 \mathrm{~mm}$ long, 0.14 $0.17 \mathrm{~mm}$ wide, length/width ratio 1.0-1.6; posterior canal is deep sinus, almost detached from aperture, 0.08-0.12 mm long. Light brown to cream-white protoconch, dirty-white to cream-white teleoconch.

\section{Remarks}

Sagenotriphora sp. 1, sampled near the mouth of the Amazon River, is similar in several shell features to S. candidula from Florida (USA). The most distinct aspect is the variable shell color of Sagenotriphora sp. 1. It varies from a light brown protoconch and white teleoconch, similar but not equal to typical S. candidula (Fig. 14, usually much clearer than Brazilian shells), to a whitened protoconch or even an almost cream teleoconch in other shells (Fig. 15A-D), which is somewhat similar to the common western Atlantic species $S$. osclausum. The white appearance of $S$. candidula is much more common than the gold appearance of $S$. osclausum in the examined material of Sagenotriphora sp. 1. It is plausible that Sagenotriphora sp. 1 is a third species of this genus in the western Atlantic, considering the impact of the Amazon River in this region (see Discussion). Once again, the study of soft parts is crucial, as $S$. osclausum and $S$. candidula were mainly distinguished by radular morphology, in addition to differences in shell color (Rolán \& Fernández-Garcés 2008). Nevertheless, a few shells of S. osclausum are also found among the paratypes of $S$. candidula (Fig. 14G).

\section{Geographical records}

Brazil: Amapá.

\section{Bathymetric distribution}

Depth: $72-103 \mathrm{~m}$.

\section{Sagenotriphora sp. 2}

Figs 16, 24E, 64

\section{Material examined}

BRAZIL - Rio de Janeiro • 1 spec.; REVIZEE-Central C1-D3; IBUFRJ 19556.

\section{Description}

Shell sinistral, elongated, cyrtoconoid, slightly convex profile, $3.1 \mathrm{~mm}$ long, $1.1 \mathrm{~mm}$ wide, length/width ratio 2.8. Protoconch multispiral, conical, 4.5 convex whorls, $0.48 \mathrm{~mm}$ long, $0.36 \mathrm{~mm}$ wide; embryonic shell dome-shaped, covered by irregular-shaped granules, vesicular granules appearing in final and abapical portion of embryonic shell, resulting in axial ribs of larval shell; larval shell with two spiral cords, situated at $\sim 27 \%$ and $\sim 58 \%$ of last whorl height; 33 nearly rectilinear to slightly sigmoid axial ribs. Teleoconch with seven whorls; two spiral cords, abapical one continuous to that of protoconch, median spiral cord absent; spiral cords initially with same strength, abapical cord becomes broader betwen beginning of fourth and end of fifth whorls, but adapical cord becomes most developed in following whorls; on body whorl, spiral cords are $1.4 \times$ as wide as distance between them; weak axial ribs, irregularly disposed, orthocline to slightly opisthocline; rounded and very close nodules (with reduced internodular spaces), with medium to large size, according to thickness of spiral cord; welldeveloped and spaced suture, with strong and wavy sutural cord; subperipheral and two basal cords spaced and wavy, sometimes developing minute nodules, especially in subperipheral cord; two very small supranumerical cords appear near peristome, one between adapical and abapical spiral cords, other 
between abapical and subperipheral cords; elliptical aperture, $0.62 \mathrm{~mm}$ long, $0.41 \mathrm{~mm}$ wide, length/ width ratio 1.5 ; totally open anterior canal, curved downwards, $0.20 \mathrm{~mm}$ long, 0.22 wide, length/width ratio 0.9; posterior canal is deep notch, $0.17 \mathrm{~mm}$ long, not detached from aperture. Beige teleoconch, light brown protoconch, darker than teleoconch.

\section{Remarks}

The protoconch of Sagenotriphora sp. 2 is very similar to that of S. osclausum, with the embryonic shell possessing vesicular granules (Fig. 16G) and the larval shell with two median spiral cords of equal strength (Fig. 16F), in addition to a similar shell color. Their main differences comprise Sagenotriphora sp. 2 not developing a median spiral cord until the end of the seventh whorl of teleoconch (whereas such cord emerges in the fourth or fifth whorl in S. osclausum), but showing a change of thickness of spiral cords throughout the teleoconch (Fig. 16B-C) (whereas cords with nearly the same thickness in S. osclausum). In addition, Sagenotriphora sp. 2 has a considerable development of the suture and very reduced internodular spaces in spiral cords of teleoconch (internodular spaces more developed in S. osclausum). This species is tentatively placed in Sagenotriphora solely due to its resemblance with S. osclausum.

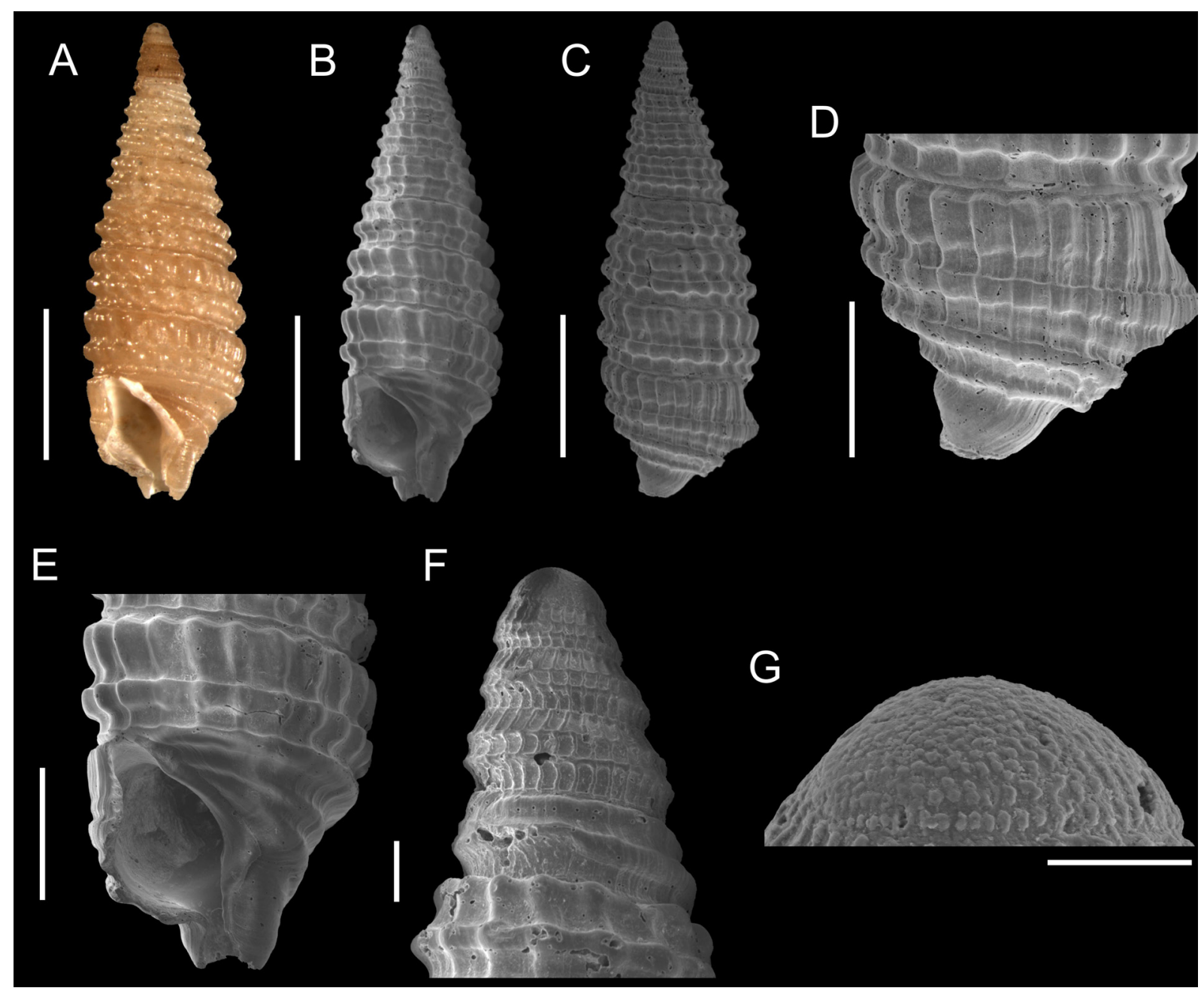

Fig. 16. Sagenotriphora sp. 2. A-G. IBUFRJ 19556, 3.09 mm. Scale bars: A-C = $1 \mathrm{~mm}$; D-E $=500 \mu \mathrm{m}$; $\mathrm{F}=100 \mu \mathrm{m} ; \mathrm{G}=50 \mu \mathrm{m}$. 


\section{Geographical records}

Brazil: Rio de Janeiro.

\section{Bathymetric distribution}

Only known from $80 \mathrm{~m}$ depth.

Genus Similiphora Bouchet, 1985

\section{Type species}

Triphora similior Bouchet \& Guillemot, 1978. Original designation. Recent, northeastern Atlantic and Mediterranean.

$$
\begin{gathered}
\text { Similiphora lucida } \text { sp. nov. } \\
\text { urn:1sid:zoobank.org:act:A3AA98F7-3D0C-4487-9857-82223BBF954E }
\end{gathered}
$$

Figs 17, 24G, 66

\section{Diagnosis}

Median spiral cord usually emerges in the third or fourth whorl of the teleoconch; snow-white shell, adapical spiral cord of the teleoconch usually with a faint to much distinct brown color throughout midlate whorls.

\section{Etymology}

The specific name is derived from the latin 'lucidus', meaning 'lucid, bright' and alluding to the white shell color.

\section{Material examined}

\section{Holotype}

BRAZIL - Maranhão • 01ํ53' S, 43²0' W; depth 33 m; 22 Nov. 2008; MZSP 92075.

\section{Other material}

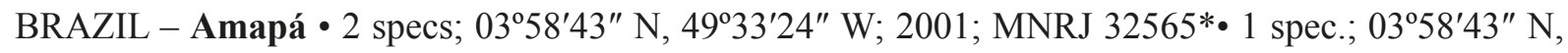

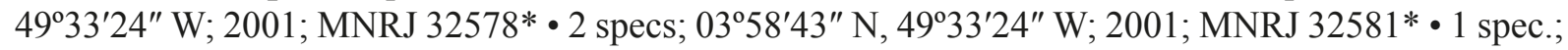
035' $43^{\prime \prime}$ N, 49³3'24" W; 2001; MNRJ 32584*. - Rio Grande do Norte • 10 specs; BPot 1-MR32; MNRJ 31602* • 4 specs; BPot 1-MR41; MNRJ 31603* • 3 specs; BPot 1-MR42; MNRJ 31604* • 7 specs; BPot 1-MR43; MNRJ 31605* • 1 spec.; BPot 1-MR44; MNRJ 31606* • 1 spec.; BPot 1-MR45; MNRJ 31607* • 1 spec.; BPot 2-MR32; MNRJ 31608* • 1 spec.; BPot 2-MR34; MNRJ 31609* • 2 specs; BPot 2-MR41; MNRJ 31610* • 6 specs; BPot 2-MR42; MNRJ 31611*•1 spec.; BPot 2-MR44; MNRJ 29396* • 1 spec.; BPot 2-MR44; MNRJ 31612*.

\section{Description}

Shell sinistral, elongated, cyrtoconoid, nearly rectilinear profile, up to $4.7 \mathrm{~mm}$ long, $1.3 \mathrm{~mm}$ wide, length/ width ratio 3.2 to 3.4. Protoconch multispiral, conical, five to 5.5 convex whorls, $0.54-0.65 \mathrm{~mm}$ long, 0.41-0.49 mm wide; embryonic shell dome-shaped, entirely covered by small rounded granules; larval shell with two faint and close spiral cords occupying mid (adapical cord) and abapical (abapical cord) portion of each whorl, respectively situated at $\sim 45 \%-46 \%$ and $\sim 66 \%-72 \%$ of last whorl height; abapical cord weakening and disappearing before transition to teleoconch; $\sim 30$ rectilinear to slightly sigmoid axial ribs. Teleoconch with up to 9.5 whorls; two spiral cords (adapical and abapical) at beginning, the abapical one continuous to adapical cord of protoconch; median spiral cord emerging in third or fourth 
whorl (rarely as late as beginning of fifth whorl), reaching same size of abapical cord (adapical one slightly more prominent in late whorls) after one to two whorls; on body whorl, spiral cords are 1.0 $1.4 \times$ as wide as distance between them; 17-20 orthocline to slightly opisthocline axial ribs; rounded to
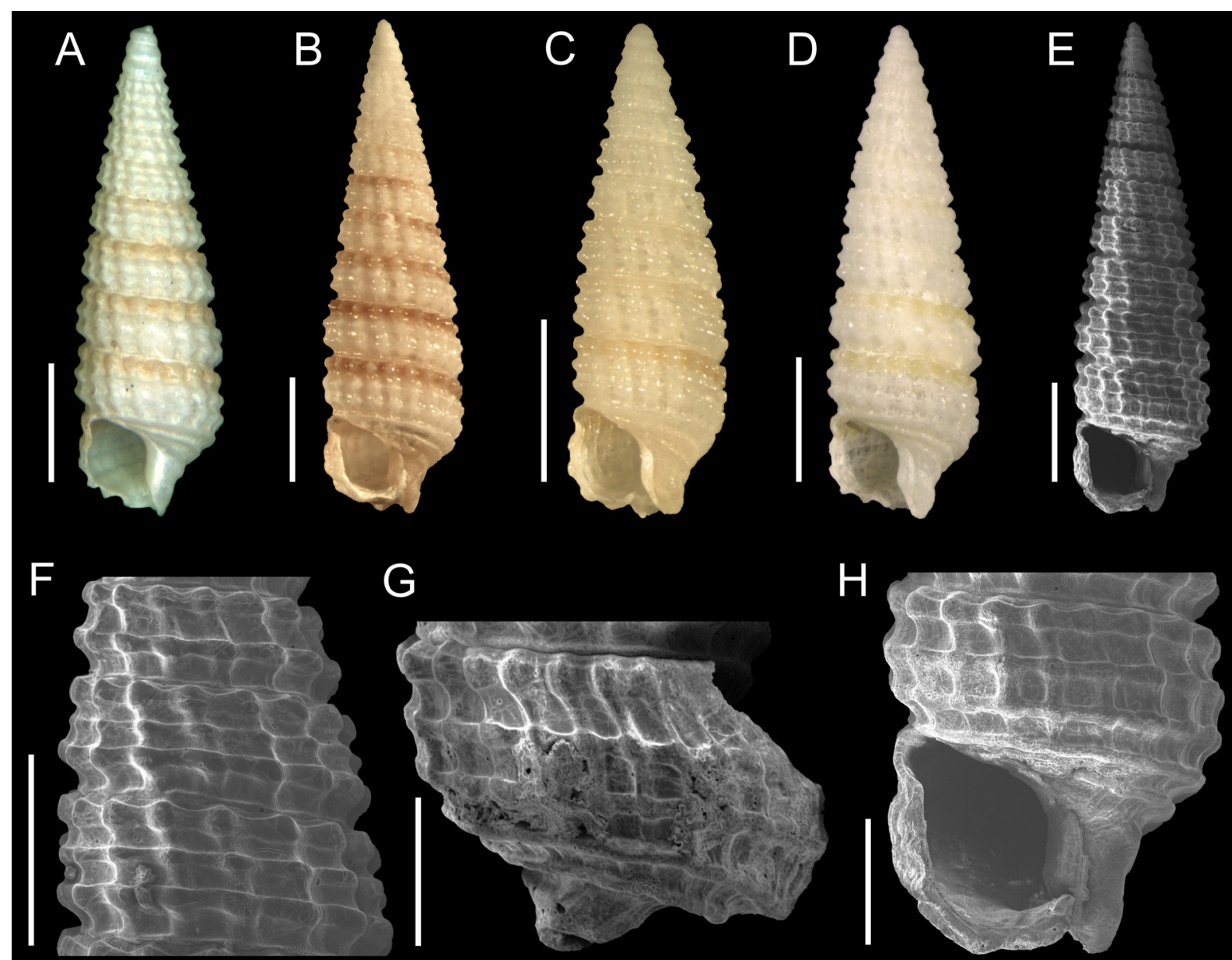

G
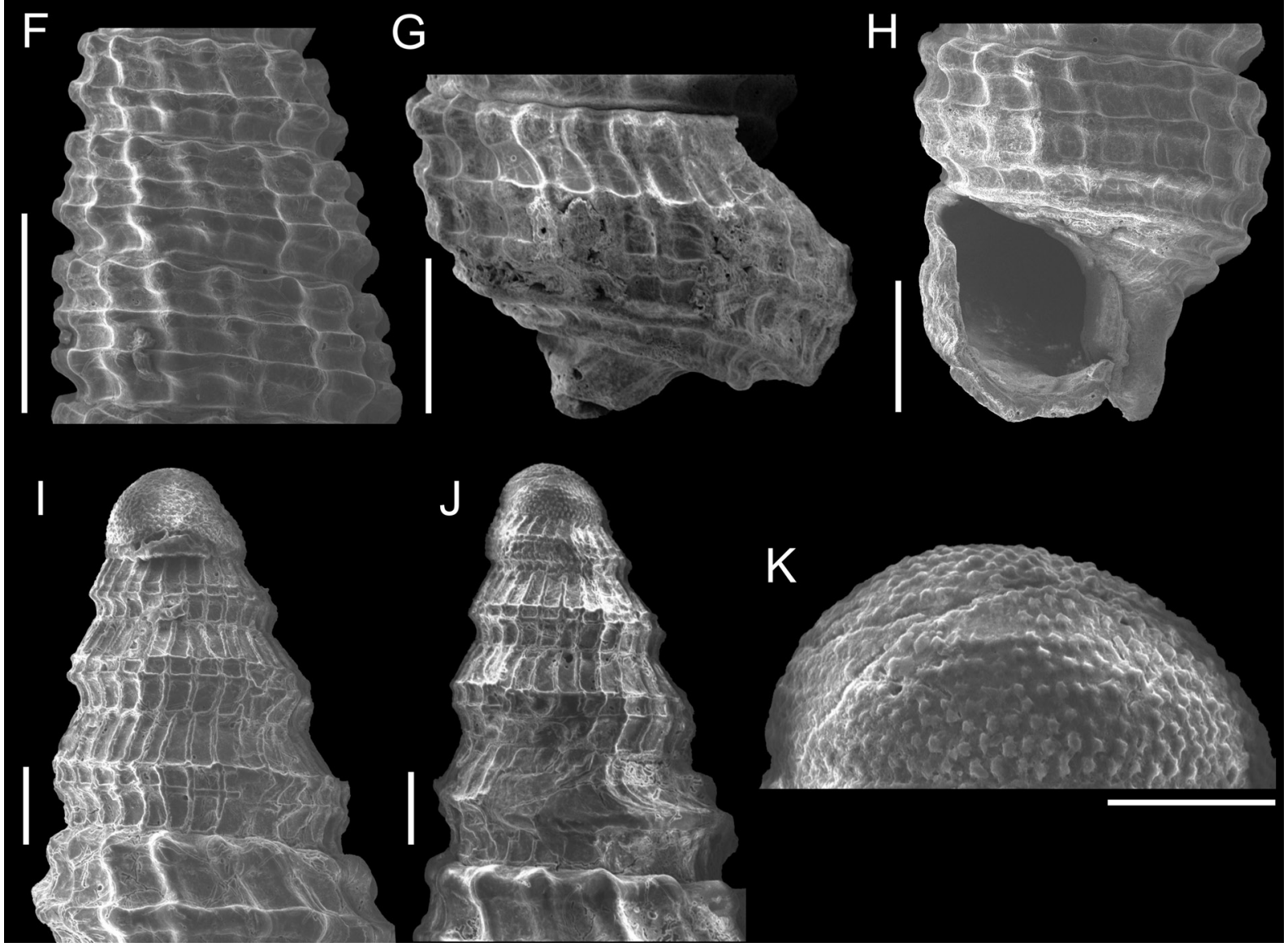

Fig. 17. Similiphora lucida sp. nov. A. MZSP 92075, holotype, $4.14 \mathrm{~mm}$. B. MNRJ 29396*, $4.73 \mathrm{~mm}$. C. MNRJ 31603*, $2.84 \mathrm{~mm}$. D. MNRJ 31602*, $3.97 \mathrm{~mm}$. E-H. Same shell as B. I-K. Same shell as C. Scale bars: A-E $=1 \mathrm{~mm} ; \mathrm{F}-\mathrm{H}=500 \mu \mathrm{m} ; \mathrm{I}-\mathrm{J}=100 \mu \mathrm{m} ; \mathrm{K}=50 \mu \mathrm{m}$. Photo credits A: Daniel Abbate (MZUSP). 
slightly elliptical (especially in abapical cord), medium-sized nodules; distinct, well-developed suture, with small sutural cord; wavy subperipheral cord, usually not developing nodules, two slightly wavy to smooth basal cords; small supranumerical cord may emerge between median and abapical spiral cords; ovate aperture, $0.55-0.72 \mathrm{~mm}$ long, $0.42-0.51 \mathrm{~mm}$ wide, length/width ratio 1.3-1.4; anterior canal short, curved downwards, widely open, but almost crossed in its base by projection of outer lip, $0.18-0.24 \mathrm{~mm}$ long, 0.19-0.29 mm wide, length/width ratio 0.8-0.9; posterior canal is small to considerably deep and wide sinus, $0.12-0.19 \mathrm{~mm}$ long, not detached from aperture. Snow-white shell, but adapical spiral cord of teleoconch usually acquires faint to much distinct brown color throughout mid-late whorls; base usually white.

\section{Remarks}

Similiphora lucida sp. nov. is markedly different from any other triphorid, especially considering the typical larval shell of the genus (Fig. 17I-J) and the pattern of shell coloration. Some intraspecific variation exists in shells of $S$. lucida sp. nov., mainly related to the emergence of the median spiral cord of the teleoconch and the coloration of the adapical spiral cord, white to weakly or distinctly tinted with brown (Fig. 17A-D).

\section{Geographical records}

Brazil: Amapá, Maranhão and Rio Grande do Norte.

\section{Bathymetric distribution}

Depth: $20-58 \mathrm{~m}$.

Similiphora sp. 1

Figs 18B-L, 24H, 67

\section{Material examined}

BRAZIL - Amapá • 15 specs; 0358'43" N, 49³3'24" W; 2001; MNRJ 32566* • 4 specs; 0358'43" N,

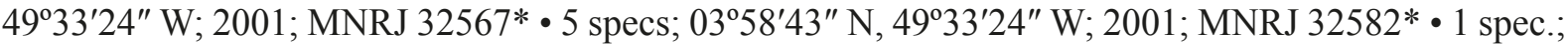

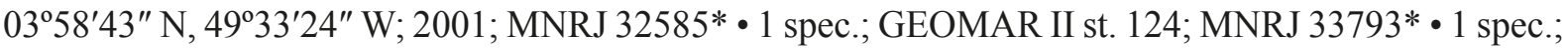
AMASSEDS st. 4134; MORG 52262 • 3 specs; AMASSEDS st. 3210; MNRJ 33800*.

BRITISH GUYANA • 1 spec.; 085' ${ }^{\prime}$ N, 59 $04^{\prime}$ W, R/V Chain Cruise 35, st. 42; depth 73-82 m; 29 Apr. 1963; MCZ 274232.

FRENCH GUYANA • 1 spec.; 06 ${ }^{\circ} 18^{\prime}$ N, 52 $2^{\circ} 13^{\prime}$ W; depth 95-97 m; 8 Aug. 2014; OC. Ship Hermano Gines leg.; MNHN-IM-2012-43226.

Other material (not included in the description) BRAZIL - Pará • 1 spec.; GEOMAR II st. D; MORG 16441*.

\section{Description}

Shell sinistral, elongated, cyrtoconoid, rectilinear to slightly convex profile, up to $3.7 \mathrm{~mm}$ long, $1.1 \mathrm{~mm}$ wide, length/width ratio 3.2 to 3.3. Protoconch multispiral, conical, 5.5-6.0 very convex whorls, 0.58 $0.70 \mathrm{~mm}$ long, $0.45-0.52 \mathrm{~mm}$ wide; embryonic shell dome-shaped, covered by small rounded granules in its abapical portion; larval shell with two faint and close spiral cords occupying the mid (adapical cord) and abapical (abapical cord) portion of each whorl, respectively situated at $\sim 49 \%$ and $\sim 74 \%$ of last whorl height, adapical cord emerging later at beginning of larval shell, abapical one weakening and disappearing before transition to teleoconch; $\sim 34$ rectilinear to slightly sigmoid axial ribs. Teleoconch 
with up to eight whorls; two spiral cords (adapical and abapical) at beginning, abapical one continuous to adapical cord of protoconch; median spiral cord emerges in third to fifth whorl, reaching same size of other cords after one to two whorls, adapical cord slightly more prominent than other cords in late

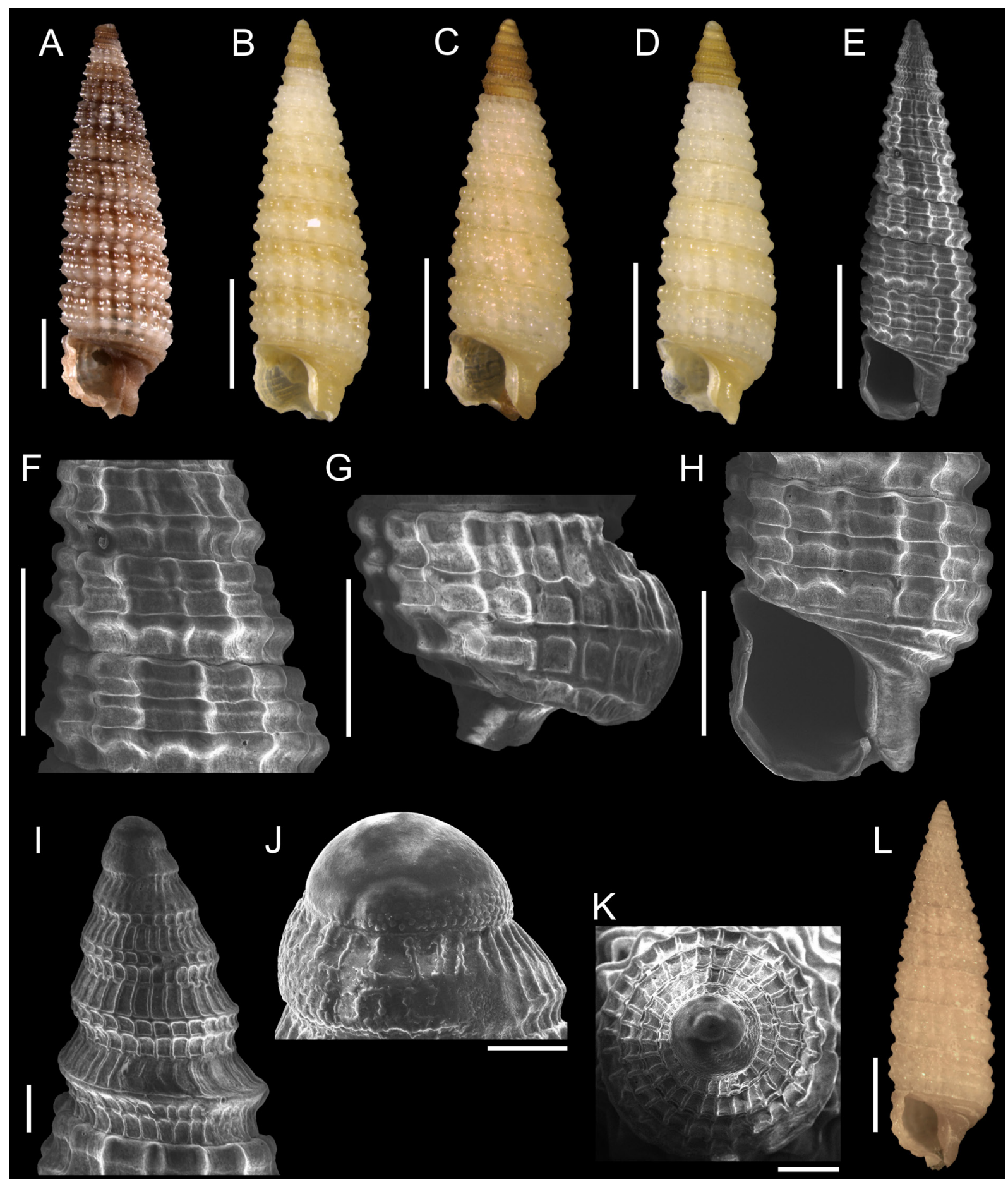

Fig. 18. A. Similiphora apexdiversus (Rolán \& Lee, 2008) comb. nov., holotype, FLMNH 363887. B-L. Similiphora sp. 1. B-D. MNRJ 32566*, $3.75 \mathrm{~mm}, 3.17 \mathrm{~mm}$ and $3.25 \mathrm{~mm}$, respectively. E-K. Same shell as C. L. MORG 16441*, $5.18 \mathrm{~mm}$. Scale bars: A-E, L $=1 \mathrm{~mm}$; F-H $=500 \mu \mathrm{m} ; \mathrm{I}, \mathrm{K}=100 \mu \mathrm{m}$; $\mathrm{J}=50 \mu \mathrm{m}$. 
whorls of some shells; on body whorl, spiral cords are 1.2-1.4 $\times$ as wide as distance between them; 16-17 nearly orthocline axial ribs; rounded nodules, with medium size; distinct, well-developed suture, with small sutural cord; wavy subperipheral cord, usually not developing nodules, two nearly smooth basal cords; no supranumerical cords; ovate aperture, $0.54-0.61 \mathrm{~mm}$ long, $0.44-0.51 \mathrm{~mm}$ wide, length/ width ratio 1.2; anterior canal moderately short to medium-sized, curved downwards, open, but almost crossed at its base by the projection of outer lip, 0.18-0.26 mm long, $0.13-0.18 \mathrm{~mm}$ wide, length/width ratio 1.0-2.0; posterior canal is wide sinus, $0.10-0.17 \mathrm{~mm}$ long, not detached from aperture. Protoconch light brown; teleoconch with whitish background, adapical spiral cord may be or not slightly darker, with faint cream-brownish coloration; base may be or not slightly darker.

\title{
Remarks
}

Similiphora sp. 1 is very similar to the widespread western Atlantic species S. intermedia and an endemic species from Florida (USA), Similiphora apexdiversus (Rolán \& Lee, 2008) comb. nov. (Fig. 18A), previously allocated to Marshallora despite the typical protoconch of Similiphora (Rolán \& FernándezGarcés 2008: fig. 8g). Similiphora sp. 1 apparently has smaller adult shells and a whitened teleoconch (sometimes with a faint cream-brownish band in the adapical spiral cord), instead of the distinct brown spiral bands in S. intermedia and the slightly darker teleoconch of S. apexdiversus comb. nov. The absence of soft parts and the great similarity with the two above-mentioned species preclude the description of Similiphora sp. 1 as a new species.

The moderately large shell of MORG 16441 (Fig. 18L) does not fit exactly into the definition of Similiphora sp. 1. That shell is homogeneously cream, reaching $5.2 \mathrm{~mm}$ to nine whorls of the teleoconch, instead of Similiphora sp. 1 (up to $3.7 \mathrm{~mm}$, eight whorls).

\section{Geographical records}

British Guyana; French Guyana; Brazil: Amapá.

\section{Bathymetric distribution}

Depth: 45-103 m.

\section{Some considerations to species previously recorded from Brazil}

\author{
Genus Coriophora Laseron, 1958
}

\section{Type species}

Coriophora negrita Laseron, 1958. Original designation. Recent, western Pacific.

\section{Coriophora novem (Nowell-Usticke, 1969)}

Fig. 19, 22H, 30, 83

Triphora novem Nowell-Usticke, 1969: 12, pl. 2 fig. 403.

Triphora novem - De Jong \& Coomans 1988: 49, pl. 34 fig. 236. — Moolenbeek \& Faber 1989: 80. — Boyko \& Cordeiro 2001: 122.

Triphora sp. indet. A - Odé 1989: 111, fig. 6.

Marshallora sp. 1 - Leal 1991: 121, pl. 16 figs h-i.

Mesophora aff. novem - Rolán \& Fernández-Garcés 1995: 11, figs 12-16.

Mesophora novem - Rolán \& Fernández-Garcés 1995: 11, figs 8-11; 2007: 23, pl. 4 figs 1-5. — Redfern 2001: 67, pl. 33 fig. 282; 2013: 129, fig. 367. — Espinosa et al. 2007: 74; 2012: 257. — Lee 2009: 90. — Tunnell et al. 2010: 205. — Garcia \& Lee 2011. — García 2016: 106. 
Coriophora novem - Zhang 2011: 101, fig. 299 (Mesophora novem). — Özdikmen 2013: 255. — Fernandes et al. 2013: 12, figs 12, 23, 33. — Rolán \& Fernández-Garcés 2015: 54, pl. 4 fig. i. Hewitt \& van Leeuwen 2017: 54. — Lamy \& Pointier 2018: 284, pl. 91 fig. 4.

\section{Material examined}

Holotype

VIRGIN ISLANDS・AMNH 195419.

\section{Other material}

BELIZE • 1 spec.; Carrie Bow Cay; 16²47'30" N, 8804'42" W; 27 May 1972; R. Houbrick leg.; USNM 879550 .

BONAIRE• 1 spec.; Nukove; 21 m; 14 Feb. 1998; MNRJ 32363*.

BRAZIL - Amapá • 1 spec.; GEOMAR III st. 181; UFC-Labomar 1894. - Rio Grande do Norte • 1 spec.; BPot 1-MR43; MNRJ 31542* • 2 specs; BPot 1-MR45; MNRJ 31543* • 1 spec.; BPot 2-MR45; MNRJ 31544* • 1 spec.; 0444'53" S, 36²5'27" W; depth 102-108 m; 23 May 2011; MNRJ 35118*. Pernambuco • $1 \mathrm{spec}$.; Porto de Galinhas, Ipojuca; 5 Oct. 1982; UFRPE. - Alagoas • 4 specs; Maceió; Jaraguá; MORG 18264 • 37 specs; Maceió; Jaraguá; MORG 33736. - Bahia • 3 specs; Salvador; Itapuã; MORG 16385• 4 specs; Salvador; Itapuã; MORG 33727 • 9 specs; Salvador; Itapuã; MORG 52615 • 1 spec.; Salvador; Itapuã; MORG 33742 • 1 spec.; Salvador; Itapuã; MZSP 133316 • 1 spec.; Salvador, beach drift; Apr. 1981; J.C. Tarasconi leg.; MNRJ 29366* • 2 specs; Salvador; MZSP 64881 • 1 spec.; 13²5'43" S, 3849'30" W; depth 33 m; MNRJ 33085* • 5 specs; Ilhéus MNRJ 32374* • 1 spec.; Ilhéus MNRJ 32975* • 1 spec.; REVIZEE-Central C5-7R; MNRJ 18631* • 1 spec.; Abrolhos; Jan. 1985; MORG 29825. - Espírito Santo • 1 spec.; 19²6' S, 39²2' W; depth 46 m; Oct. 2003; MNRJ 32134* • 1 spec.; 19²6'03" S, 39²2'35" W; depth 44 m; Oct. 2003; MNRJ 32838*. -Vitória-Trindade Chain • 3 specs; REVIZEE-Central C2-22R; MORG 52620 • 1 spec.; Trindade Island; Mar. 1986; H. Bulhões leg.; MORG 24433. - Campos Basin (Espírito Santo/Rio de Janeiro) • 1 spec.; HAB 16-C4; MNRJ 18434*• 1 spec.; HAB 16-H3; MNRJ 18622* • 1 spec.; 22 $42^{\prime}$ S, 4040' W; depth 110 m; 2006; MNRJ 18754* • 2 specs; $23^{\circ} 04^{\prime}$ S, $40^{\circ} 59^{\prime}$ W; 17 Dec. 2004; MNRJ 18963* • 1 spec.; $23^{\circ} 04^{\prime}$ S, 4059' W; 1 Apr. 2005; MNRJ 31110*・1 spec.; 230' S, 4059' W; MNRJ 32625*.

\section{Remarks}

Rolán \& Fernández-Garcés (1995) and Fernandes et al. (2013) discussed the existence of two morphs under the name $C$. novem, one lighter in colour (like the holotype), the other darker. Typical shells of C. novem in southeastern Brazil belong to the darker morph (Fig. 19A), besides showing the median spiral cord of the teleoconch emerging between the seventh and ninth whorl (Fernandes et al. 2013; Fernandes 2014). Some shells from northeastern Brazil are similar to the holotype, with a clearer coloration; a few of them are smaller and have smooth basal cords, a reduced anterior canal and the median spiral cord emerging early, even at the fifth whorl of the teleoconch (Fig. 19C).

Fernandes et al. (2013) indicated some inconsistencies related to the larval shell and radular formula in the generic assignment of C. novem in Mesophora Laseron, 1958 (synonym of Coriophora Laseron, 1958; see Marshall 1983 and Özdikmen 2013) by Rolán \& Fernández-Garcés (1995). The discovery of a spiral microsculpture in the teleoconch of C. novem (Fig. 19F-G) is relevant, as it is very weak or usually absent in Mesophora (Marshall 1983) but distinct in the related genus Mastonia Hinds, 1843. Additionally, Mastonia typically has two spiral cords in the larval shell, just as in most part of the larval shell of C. novem (Fig. 19J), instead of the usual single cord in Mesophora (Marshall 1983). In contrast, C. novem possesses two basal cords (Fig. 19H) and a shell shape more similar to Mesophora, different from the bottle-shaped shell of Mastonia, which has only one basal cord (Marshall 1983). Both genera 
are also distinguished by the more developed aperture and later emergence of the median spiral cord of the teleoconch in Mastonia (Laseron 1958; Marshall 1983), but they share features such as the late median spiral cord and the strongly opisthocline orientation of axial ribs posteriorly to the body whorl. Except for C. novem, Coriophora/Mesophora and Mastonia are restricted to the Indo-Pacific.

According to Marshall (1983), the radulae of the type species of Coriophora, Mesophora, Mastonia and Iniforis Jousseaume, 1884 are quite similar. The radula of $C$. novem, illustrated in Rolán \& Fernández-

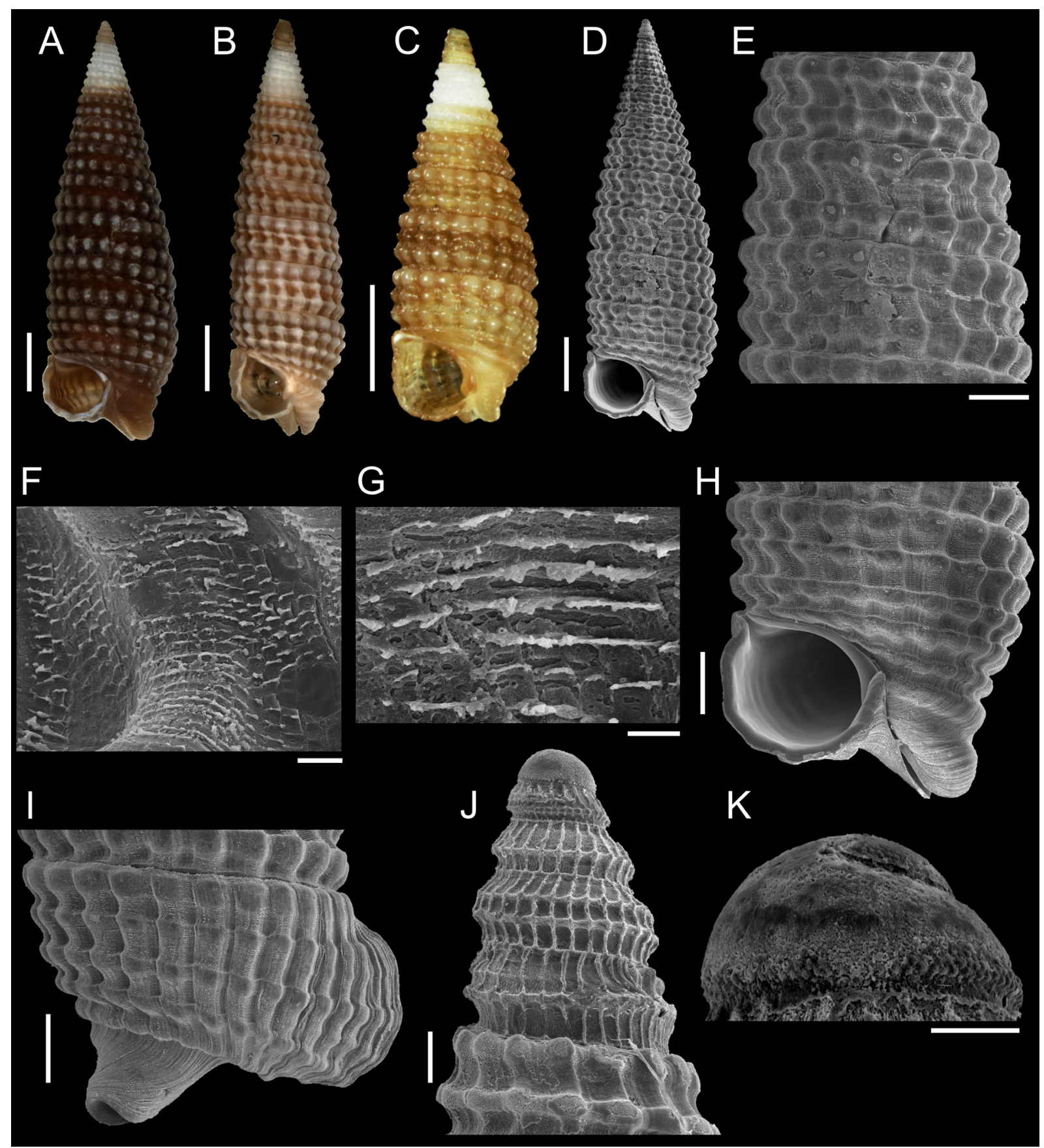

Fig. 19. Coriophora novem (Nowell-Usticke, 1969). A. MNRJ 18754*, 7.35 mm. B. MNRJ 18963*, $6.24 \mathrm{~mm}$. C. MNRJ 29366*, $3.73 \mathrm{~mm}$. D-K. Same shell as A (F-G: micro-spiral sculpture in the teleoconch). Scale bars: A-D = $1 \mathrm{~mm} ; \mathrm{E}, \mathrm{H}-\mathrm{I}=500 \mu \mathrm{m} ; \mathrm{F}, \mathrm{K}=50 \mu \mathrm{m} ; \mathrm{G}=20 \mu \mathrm{m} ; \mathrm{J}=100 \mu \mathrm{m}$. 
Garcés (1995) under the name Mesophora aff. novem, has combined features of those genera: the central tooth is similar to that of all except Mastonia, lateral teeth are more similar to those of Coriophora (in number and shape of cusps), and marginal teeth are only similar to those of Iniforis, distinct from the remaining genera because the central cusp is not elongated and thin. The radular formula of $C$. novem (12-1-1-1-12) is distinct from that of Mesophora (24-1-1-1-24), but identical to the type species of Mastonia (Kosuge 1966); the radular formula of the type species of Coriophora and Iniforis is not known. Marshall (1983: 45) considered Mesophora (currently accepted as Coriophora), Mastonia and Iniforis as closely related genera, warning that "it will be essential to compare radulae of many more species to ascertain the extent of variation within the groups". The spiral microsculpture of Mastonia is quite different from that of other genera, consisting of distinct rows of small nodules covering all interspaces between the main spiral cords (Fig. 20; Marshall 1983: fig. 20c), whereas C. novem exhibits a pattern more similar to that of some species of Iniforis (e.g., Rolán \& Fernández-Garcés 2009: fig. 29), i.e., more discrete and resembling a peeled surface (Fig. 19F-G). As above-mentioned, C. novem has some features more similar to those of Coriophora, others to Mastonia; it is preferred to maintain this species in the former genus, although pending future fine anatomical comparisons and molecular data. A proposition for a new genus exclusive to this western Atlantic species is possible, instead of tentatively maintaining it in Indo-Pacific genera.

\section{Geographical records}

USA: Florida (Lee 2009), Louisiana (Garcia \& Lee 2002), Texas (Tunnell et al. 2010); Gulf of Mexico (Rosenberg et al. 2009); Bahamas (Redfern 2001); Cuba (Rolán \& Fernández-Garcés 1995); Jamaica (Rosenberg 2009); Puerto Rico (Lee 2009); Virgin Islands (type locality); Antigua (Lamy \& Pointier 2018); Guadeloupe (Rolán \& Fernández-Garcés 2015); Belize (this study); Aruba, Bonaire and Curaçao (De Jong \& Coomans 1988); Brazil: Amapá, Rio Grande do Norte, Pernambuco to Alagoas, Bahia (this study), Sulphur Bank, Vitória-Trindade Chain (Fernandes et al. 2013), Espírito Santo to Rio de Janeiro (this study).

\section{Bathymetric distribution}

Depth: 2 m (Rolán \& Fernández-Garcés 1995) to 110 m (this study).

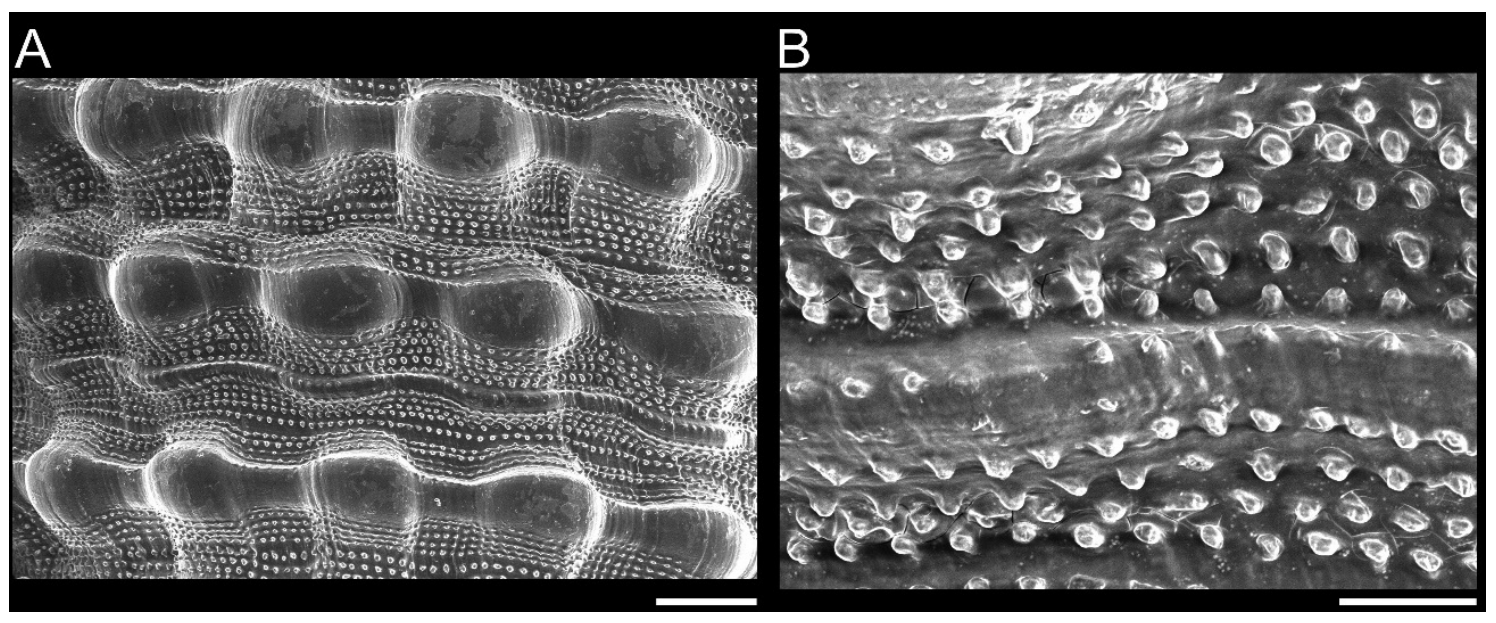

Fig. 20. Micro-spiral sculpture of Mastonia rubra (Hinds, 1843). A-B. MNRJ 28879*, Niuatoputapu, Tonga, Polynesia, T. McCleery leg., Aug. 2003. Scale bars: A $=200 \mu \mathrm{m} ; \mathrm{B}=50 \mu \mathrm{m}$. 
Genus Cosmotriphora Olsson \& Harbison, 1953

\title{
Type species
}

Cerithium melanura C.B. Adams, 1850. Original designation. Recent, western Atlantic.

\author{
Cosmotriphora cf. melanura (C.B. Adams, 1850)
}

Figs 21A-F, 32

\section{Material examined}

BAHAMAS • 1 spec.; Abaco; depth 12 m; 19 Jul. 1983; C. Redfern leg.; BMSM 55421 • 1 spec.; Abaco; depth 3 m; 12 Aug. 1981; C. Redfern leg.; BMSM 55419 • 6 specs; Abaco; depth 7 m; 13 Aug. 2005; C. Redfern leg.; BMSM 55425 • 5 specs; Abaco; depth 7 m; 12 Aug. 2007; C. Redfern leg.; BMSM 55426.

BRAZIL-Amapá • 1 spec.; Cabo Orange; depth 103 m; Nov. 1968; MORG 14448*• 1 spec.; 0358'43" N, 49³3'24" W; 2001; MNRJ 32571* • 3 specs; off Amapá; Apr. 1997; MORG 39890*. - Ceará • 2 specs; Canopus Bank; 02 $14^{\prime} 25^{\prime \prime}$ S, 38 22'50" W; depth 60-70 m; Aug. 2005; MZSP 70279 • 2 specs; Canopus Bank; 02 ${ }^{\circ} 14^{\prime} 25^{\prime \prime}$ S, 38 $22^{\prime} 50^{\prime \prime}$ W; depth 60-70 m; Aug. 2005; MZSP 53736. - Rio Grande do Norte • 1 spec.; BPot MT54; MNRJ 35176* • 1 spec.; Potiguar Basin; MNRJ 35182*. - São Pedro e São Paulo Archipelago • 1 spec.; Jul. 2003; G. Vianna leg.; MNRJ 32421* • 1 spec.; Apr. 2001; P.S. Oliveira leg.; MORG 42626 • 1 spec.; 00 $56^{\prime}$ N, 29²2' W; 2 Nov. 2007; C.M. Cunha leg.; MZSP 87436. - Fernando de Noronha Archipelago • 21 specs; Cabeço da Sapata; depth 40 m; 5 Dec. 1985; M. Cabeda leg.; MORG 24616*.

\section{Remarks}

Most shells in the material herein examined are assigned, with restrictions, to Cosmotriphora melanura (C.B. Adams, 1850) owing to the late emergence of the median spiral cord in the fifth or even sixth whorl of the teleoconch, reaching the same size of other cords after about three or more whorls. A typical shell of C. melanura has the median cord emerging in the third or fourth whorl, reaching the same size of other cords after one whorl. Typical shells of $C$. melanura were also herein listed, being usually sympatric with the atypical ones.

Triforis grimaldii Dautzenberg \& Fischer, 1906, an eastern Atlantic species originally described from the Canary Islands and Cape Verde, is widely accepted as a synonym of C. melanura (Bouchet 1985; Rolán \& Fernández-Garcés 1994; Fernandes et al. 2013), even with its median spiral cord emerging between the sixth and eighth whorl of the teleoconch (Rolán \& Fernández-Garcés 1994). Despite the suggestion of Scheltema (1971) and Fernandes \& Rolán (1994) that several species of Triphoridae can be amphi-Atlantic, only C. melanura is currently recognized as such.

In spite of the lack of knowledge about triphorid larval development, $C$. melanura seems to be the western Atlantic triphorid with the longest larval phase in the open ocean, being the commonest species in the seamounts and islands of the Vitória-Trindade Chain (Fernandes et al. 2013) and in Campos Basin (southeastern Brazil) offshore waters (Fernandes \& Pimenta 2017b). The ability of larvae to cross an ocean does not imply the panoceanic presence of adults owing to difficulties of post-larval survivorship and establishment in the new territory (Bhaud 1998), especially regarding the dietary limitations caused by the feeding mode of triphorids on particular sponges. Krug \& Zimmer (2004) and Young et al. (2012) also provided arguments against the hypothesis of frequent larval exchange across the Atlantic. Several supposedly amphi-atlantic gastropods from tropical shallow waters have been proved to be constituted 


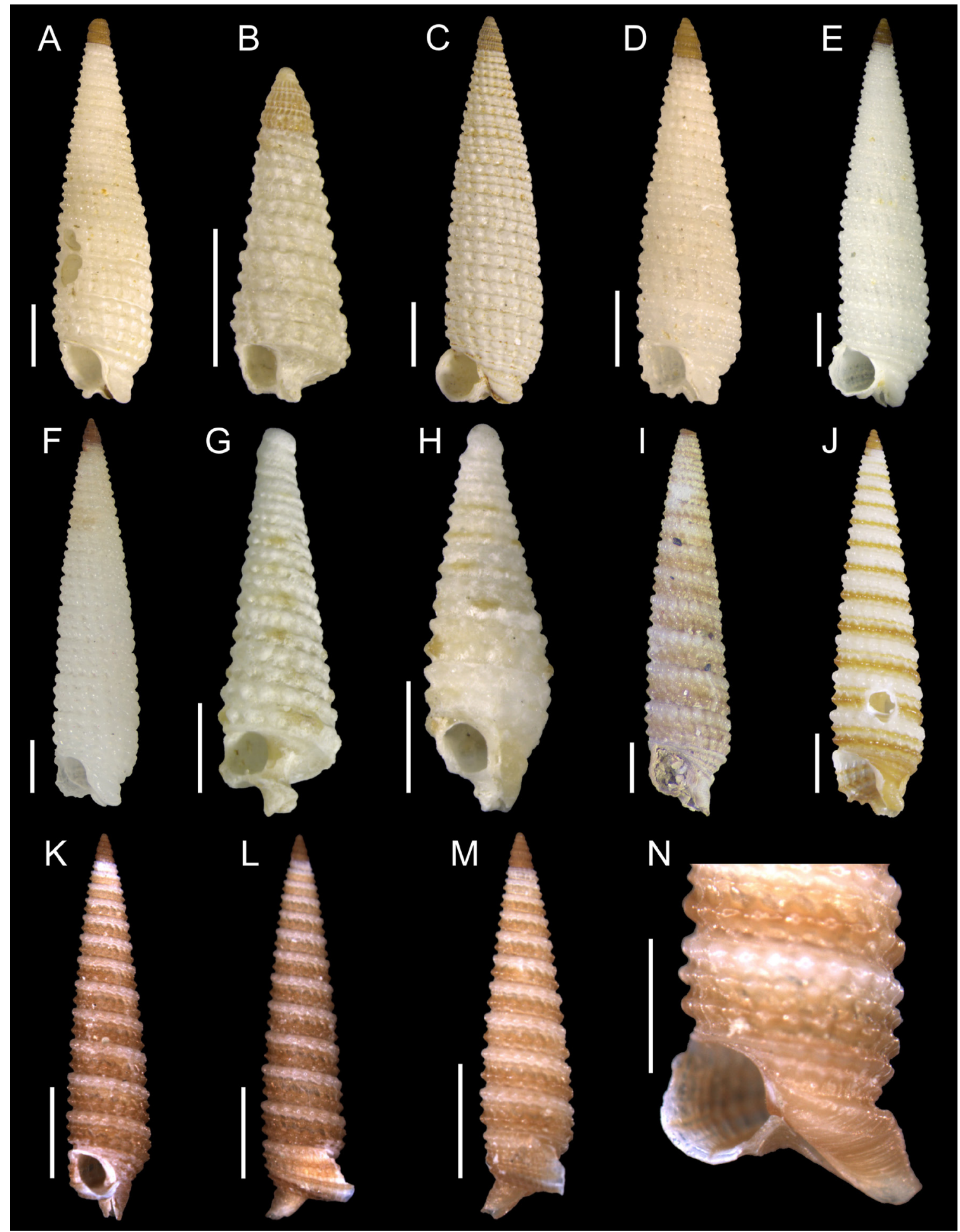

Fig. 21. A-F. Cosmotriphora cf. melanura (C.B. Adams, 1850). A. MORG 14448*, $6.15 \mathrm{~mm}$. B. MORG 39890*, $2.10 \mathrm{~mm}$. C. MNRJ 32421*, $5.97 \mathrm{~mm}$. D. MORG 24616*, 5.09 mm. E. MNRJ 35176*, 7.24 mm. F. MZSP 70279, 7.35 mm. - G-H. Iniforis carmelae Rolán \& Fernández-Garcés, 1993. G. MNRJ 35184*, 4.40 mm. H. IBUFRJ 17351, 3.38 mm. — I-N. Triphora charybdis Fernandes \& Pimenta, 2015. I. MCZ 273420, 7.75 mm. J. MNRJ 35109*, 6.57 mm. K-L. INV MOL6534, 4.25 mm. M-N. INV MOL6531, $3.39 \mathrm{~mm}$. Scale bars: A-M = $1 \mathrm{~mm} ; \mathrm{N}=500 \mu \mathrm{m}$. Photo credits K-N: Erika Montoya (INVEMAR). 
of different species (e.g., Malaquias \& Reid 2009; Claremont et al. 2011; Carmona et al. 2014), whereas others indeed show broad ranges (e.g., Claremont et al. 2011; Padula et al. 2016).

Shells of $C$. cf. melanura seem to represent an intermediate phenotype with respect to the emergence of the median spiral cord between typical C. melanura and eastern Atlantic shells. The oceanic islands of Fernando de Noronha and São Pedro e São Paulo could represent a hybrid zone, being localized above a main oceanic current connecting both sides of the Atlantic (but regarding the fact that several shells of typical C. melanura are also present there). In addition, shells of $C$. cf. melanura are often found in the Bahamas and in deeper waters of northern and upper-northeastern Brazil (see Material examined). To elucidate whether it constitutes a complex of species or just intraspecific variation, an integrative taxonomic approach is needed. Sampling must also include oceanic islands that may serve as stepping stones for this species, like St. Helena Island (Smith 1890).

Another hypothesis on the variation in shell morphology of $C$. cf. melanura proposes phenotypic plasticity owing to latent effects of the larval development (Pechenik 2006). A common feature between atypical shells from oceanic islands and deep records is a possibly extended larval period in the water column if there is no habitat for settlement. Fernandes \& Pimenta (2017b) suggested that the protoconch of $C$. melanura has a different color when larvae spend a long period in the water column. At least in northern and part of northeastern Brazil, it is observed that the deeper the site, the more frequent to see atypical shells, perhaps associated to latent effects and stress during an extended larval development (Pechenik 2006). In contrast, isolated oceanic islands contain both typical and atypical shells, the former possibly derived from self-retained larvae (short larval period), the latter possibly derived from distant sources; exceptions are the 'pseudo-isolated' islands of Trindade and Martin Vaz, connected to the continent by the shallow seamounts of the Vitória-Trindade Chain, not showing atypical shells. Ex situ experiments with the ontogeny of C. melanura may be conducted to evaluate if delayed metamorphosis affects the development of the median spiral cord of the teleoconch. This hypothesis, however, does not explain differences in the shell between C. melanura from both sides of the Atlantic Ocean.

Genus Iniforis Jousseaume, 1884

\section{Type species}

Iniforis malvaceus Jousseaume, 1884. Original designation. Recent, New Caledonia.

Iniforis carmelae Rolán \& Fernández-Garcés, 1993

Fig. 21G-H, 23B, 48

Iniforis carmelae Rolán \& Fernández-Garcés, 1993: 102, figs 12-15, 28-30.

Triphora sp. 3 - Leal 1991: 123, pl. 17 figs A-B.

Iniforis carmelae - Rolán \& Fernández-Garcés 2007: 21, pl. II figs 18-22. — Espinosa et al. 2007: 74; 2012: 257. — García \& Capote 2013: 29. — Fernandes et al. 2013: 7, figs 4, 20, 31.

\section{Material examined}

Holotype

CUBA • Cienfuegos; MNCN 15.05/6822.

\section{Paratypes}

See Rolán \& Fernández-Garcés (1993). 


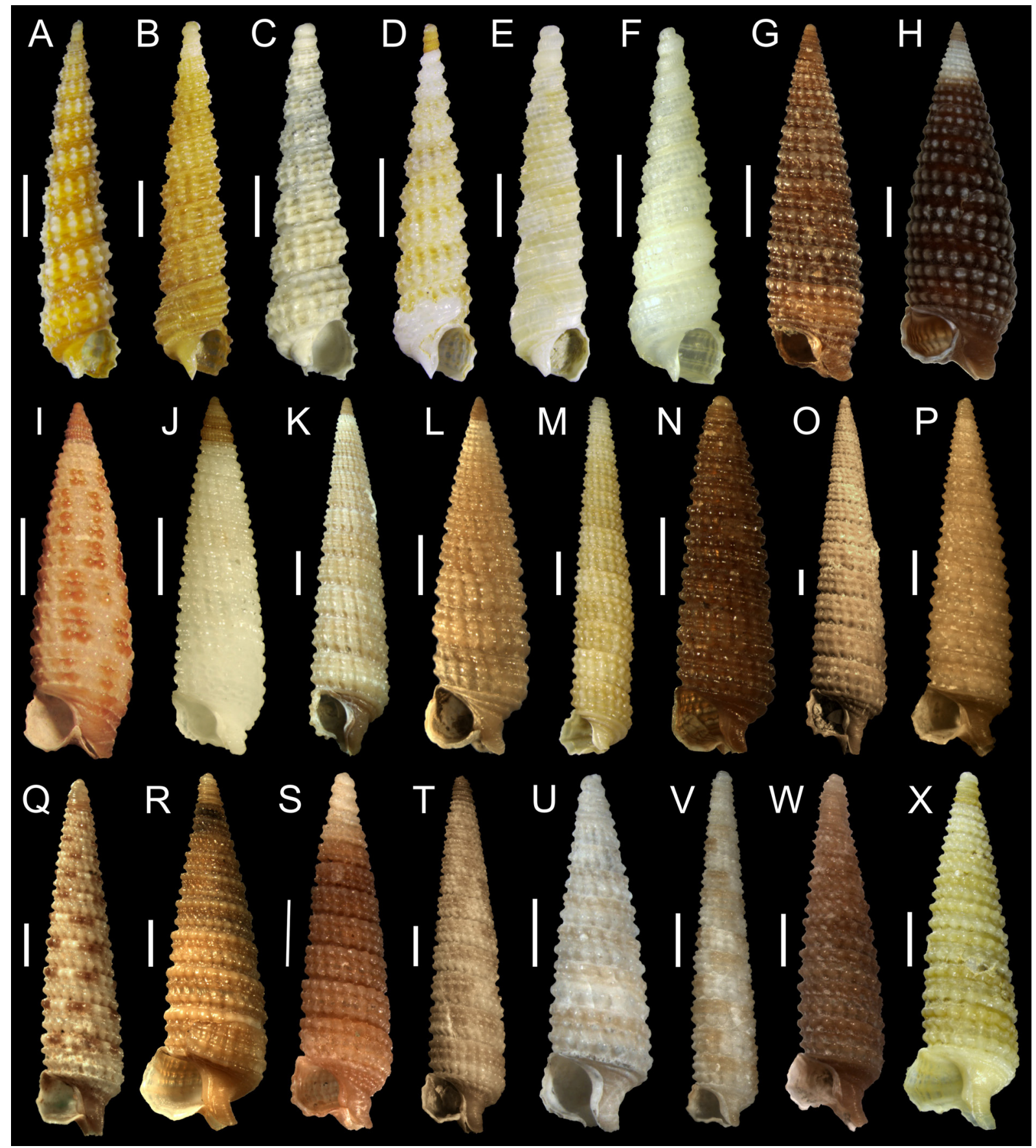

Fig. 22. Triphoridae from Brazil (1). A. Metaxia excelsa Faber \& Moolenbeek, 1991. B-C. Metaxia rugulosa (C.B. Adams, 1850). D. Metaxia taeniolata (Dall, 1889). E. Metaxia gongyloskymnus Fernandes \& Pimenta, 2011. F. Metaxia prompta Rolán \& Fernández-Garcés, 2008. G. Cheirodonta dupliniana (Olsson, 1916). H. Coriophora novem (Nowell-Usticke, 1969). I. Cosmotriphora arnoldoi Faber \& Moolenbeek, 1991. J. Cosmotriphora melanura. K. Eutriphora auffenbergi Rolán \& Lee, 2008. L. Eutriphora costai Fernandes \& Pimenta, 2015. M. Inella apexbilirata Rolán \& FernándezGarcés, 2008. N. "Inella" differens Rolán \& Lee, 2008. O. "Inella” euconfio Fernandes \& Pimenta, 2019. P. "Inella" faberi Rolán \& Fernández-Garcés, 2008. Q. "Inella" faceta Fernandes \& Pimenta, 2019. R. "Inella" galo Fernandes \& Pimenta, 2019. S. "Inella" leucocephala Fernandes \& Pimenta, 2019. T. "Inella" maculata Fernandes \& Pimenta, 2019. U. "Inella" vanilla Fernandes \& Pimenta, 2019. V. Inella sp. 1. W. "Inella" sp. 2. X. "Inella" sp. 3. Scale bars: $1 \mathrm{~mm}$. 


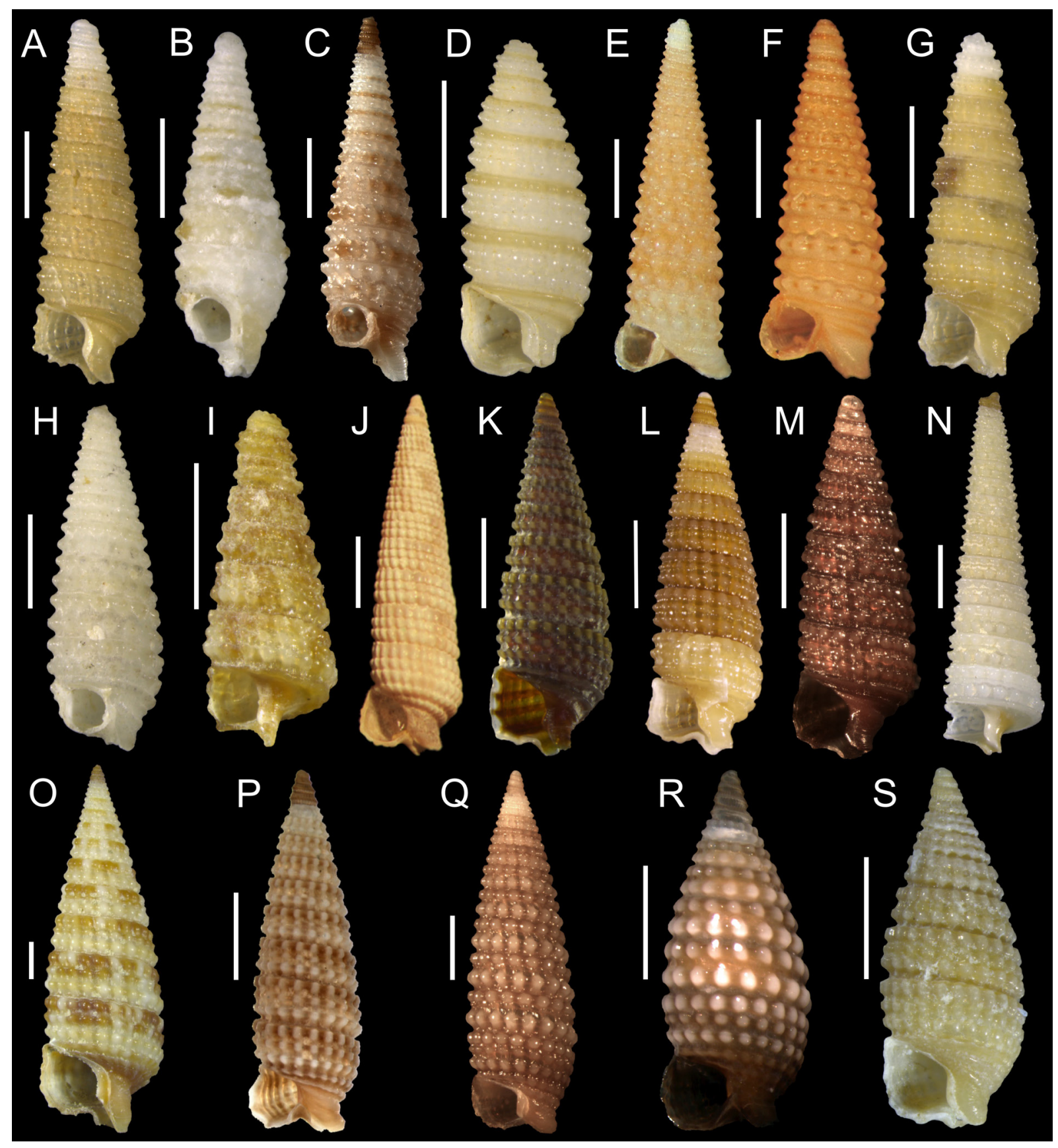

Fig. 23. Triphoridae from Brazil (2). A. "Inella" sp. 4. B. Iniforis carmelae Rolán \& FernándezGarcés, 1993. C. Iniforis pseudothomae Rolán \& Fernández-Garcés, 1993. D. Isotriphora leo sp. nov. E. Isotriphora onca Fernandes, Pimenta \& Leal, 2013. F. Isotriphora tigrina Fernandes, Pimenta \& Leal, 2013. G. Isotriphora tricingulata Rolán \& Fernández-Garcés, 2015. H. Isotriphora uncia sp. nov. I. Isotriphora sp. 1. J. Latitriphora albida (A. Adams, 1854). K. Marshallora sp. L. Marshallora ostenta Rolán \& Fernández-Garcés, 2008. M. Marshallora sp. 1. N. Monophorus caracca (Dall, 1927) comb. nov. O. Monophorus olivaceus (Dall, 1889). P. Monophorus verecundus sp. nov. Q. Nanaphora leei Fernandes \& Pimenta, 2015. R. Nanaphora verbernei (Moolenbeek \& Faber, 1989). S. Nanaphora sp. 1. Scale bars: $1 \mathrm{~mm}$. 


\section{Other material}

BRAZIL - Maranhão • 1 spec.; Parcel Manuel Luís; 16 Aug. 1997; IBUFRJ 17351. - Rio Grande do Norte • 1 spec.; Potiguar Basin; MNRJ 35184*.

\section{Remarks}

The worn shells from northeastern Brazil herein studied (Fig. 21G-H) are only the fifth/sixth records of I. carmelae from Brazil, even after the analysis of thousands of lots from several localities; all other shells were recorded from the Vitória-Trindade Chain (Fernandes et al. 2013). The paucispiral protoconch of $I$. carmelae has one whorl of larval shell, scupltured with axial ribs and a spiral cord (Rolán \& Fernández-Garcés 1993; Fernandes et al. 2013), indicative of a short but existing planctonic stage. More records may be added to the present ones in the following years, both in the Caribbean and Brazil, instead of the current geographically isolated records (but see Discussion).

\section{Geographical records}

Cuba (type locality); Brazil: Maranhão, Rio Grande do Norte (this study), Vitória-Trindade Chain (Fernandes et al. 2013).

\section{Bathymetric distribution}

5 m (Rolán \& Fernández-Garcés 1993) to 82-105 m (Fernandes et al. 2013).

$$
\text { Genus "Triphora” Blainville, } 1828 \text { s.1. }
$$

Triphora charybdis Fernandes \& Pimenta, 2015

Figs 21I-N, 24S, 77, 83, 84E

Triphora charybdis Fernandes \& Pimenta, 2015: 507, fig. 7C-K.

\section{Material examined}

Holotype

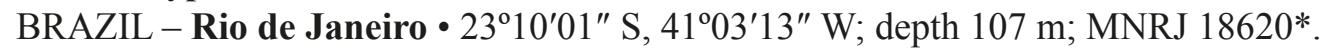

\section{Paratypes}

See Fernandes \& Pimenta (2015).

\section{Other material}

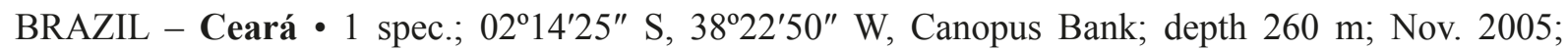
MZSP 94263. - Rio Grande do Norte • 2 specs; $04^{\circ} 44^{\prime} 11^{\prime}$ S, 36 $26^{\circ} 4^{\prime} 55^{\prime \prime} \mathrm{W}$; depth 425-450 m; 7 May 2011; MNRJ 35109* • 1 spec.; 04\%44'53" S, 36²5'27" W; depth 102-108 m; 23 May 2011; MNRJ 35116*• 2 specs; 043' $17^{\prime \prime}$ S, 36 56 $56^{\prime} 35^{\prime \prime} \mathrm{W}$; depth 130-160 m; 21 May 2011; MNRJ 35180*. - Alagoas • 1 worn spec.; 10 $32^{\prime} 07^{\prime \prime}$ S, 36 $06^{\circ} 11^{\prime \prime}$ W, MARSEAL st. BN4-R1; depth 400 m; UFS. - Rio de Janeiro • 3 specs; PADCT st. 6627; MNRJ 29387*. - São Paulo • 1 spec.; REVIZEE-Sul st. 6666; MNRJ 29379* • 3 specs; REVIZEE-Sul st. 6653; MNRJ 60189. - Paraná • 1 spec.; REVIZEE-Sul st. 6699; MNRJ 29388* • 3 specs; PADCT st. 6641; MZSP 133498 • 3 specs; PADCT st. 6595; MNRJ 29386*. - Santa Catarina - 1 spec.; PADCT st. 6635; MNRJ 29380*. - Rio Grande do Sul • 1 spec.; off Solidão; 30² $42^{\prime}$ S, 4903' W; depth 182-186 m; 6 Aug. 1972; OC. Ship W. Besnard leg.; MZSP 19331.

COLOMBIA • 1 spec.; Archipiélagos Coralinos; 0951'46" N, 76009'02" W; depth 101 m; 30 Apr. 2005; A. Clavijo leg.; INV MOL6534 - 2 specs; Archipiélagos Coralinos; 0948'04" N, 76¹1'09" W; depth 95 m; 29 Apr. 2005; A. Clavijo leg.; INV MOL6538 • 1 spec.; Archipiélagos Coralinos; 09 47'17" N, 76²11'56" W; depth 98 m; 1 May 2005; A. Clavijo leg.; INV MOL6531 • 1 spec.; Archipiélagos Coralinos; 0946'36" N, 76²12'49" W; depth 102 m; 29 Apr. 2005; A. Clavijo leg.; INV MOL6532. 


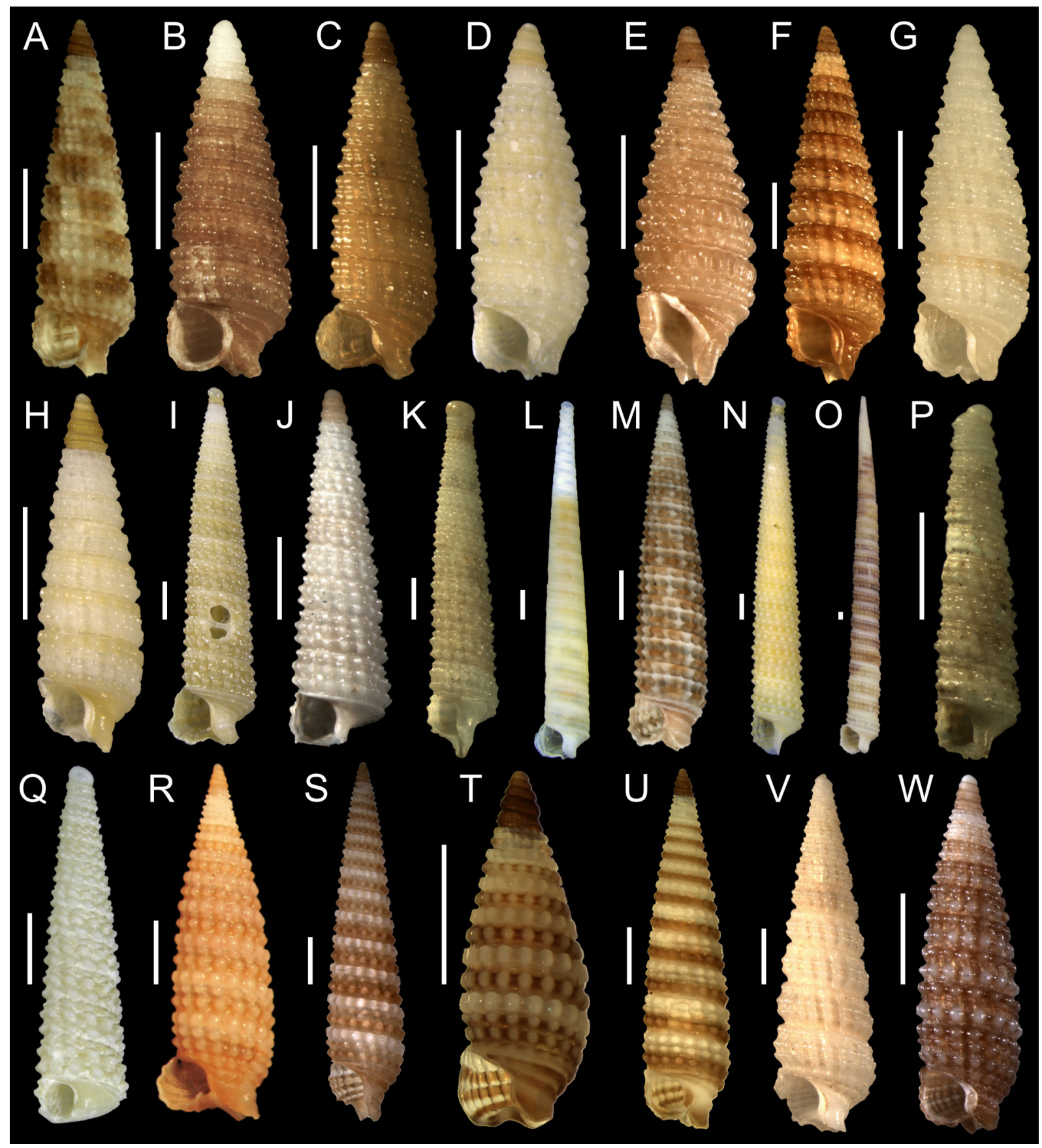

Fig. 24. Triphoridae from Brazil (3). A. Nototriphora decorata (C.B. Adams, 1850). B. Sagenotriphora albocaput sp. nov. C. Sagenotriphora osclausum (Rolán \& Fernández-Garcés, 1995). D. Sagenotriphora sp. 1. E. Sagenotriphora sp. 2. F. Similiphora intermedia (C.B. Adams, 1850). G. Similiphora lucida sp. nov. H. Similiphora sp. 1. I. Strobiligera campista Fernandes \& Pimenta, 2019. J. Strobiligera delicata Fernandes \& Pimenta, 2014. K. Strobiligera dinea (Dall, 1927). L. Strobiligera gaesona (Dall, 1927). M. Strobiligera inaudita (Rolán \& Lee, 2008). N. Strobiligera santista Fernandes \& Pimenta, 2019. O. Strobiligera unicornium (Simone, 2006). P. Strobiligera sp. 1. Q. Strobiligera sp. 2. R. Triphora atlantica Smith, 1890. S. Triphora charybdis Fernandes \& Pimenta, 2015. T. Triphora ellyae De Jong \& Coomans, 1988. U. Triphora elvirae De Jong \& Coomans, 1988. V. Triphora portoricensis Rolán \& Redfern, 2008. W. Triphora scylla Fernandes \& Pimenta, 2015. Scale bars: $1 \mathrm{~mm}$. 
GUYANA • 1 spec.; 08 $08^{\prime} 00^{\prime \prime}$ N, 57 52'30" W, R/V Chain Cruise 35, station 37; depth 82-110 m; 28 Apr. 1963; MCZ 273420.

\section{Remarks}

Fernandes \& Pimenta (2015) indicated that well-preserved shells of Triphora charybdis were sampled only in southeastern Brazil, and worn shells from Amapá and Santa Catarina were probably subfossil forms. Herein, the range of T. charybdis is extended based both on preserved and worn material (Fig. 77). Shells with a faint coloration are present northward up to the Guyana (Fig. 21I) and southward to Rio Grande do Sul (Fig. 84E). Small adult shells were found in Colombia (Fig. 21K-N), and their intact conditions indicate that this species is currently present there.

Triphora charybdis may have remained unnoticed in the Caribbean because of its moderately deep habitat, i.e., the mid-low depths of the continental shelf, and similarities with other shallow-water triphorids (Fernandes \& Pimenta 2015). However, if the pattern of worn vs preserved shells in the range of T. charybdis is confirmed after the availability of more material, a scenario of range retraction in northern and southern Brazil will be likely. In this case, living T. charybdis would be restricted to tropical waters of northeastern and southeastern Brazil, with the population from Colombia being increasingly diverged because of the lack of gene flow; their small adult size may be indicative of such a divergence.

\section{Geographical records}

Colombia (this study - well preserved); Guyana (this study - worn); Brazil: Amapá to Ceará (Fernandes \& Pimenta 2015; this study - worn), Rio Grande do Norte to Rio de Janeiro (Fernandes \& Pimenta 2015; this study - well preserved), São Paulo to Rio Grande do Sul (Fernandes \& Pimenta 2015; this study worn).

\section{Bathymetric distribution}

Depth: 80 m (Fernandes \& Pimenta 2015) to $186 \mathrm{~m}$ (this study). Some deeper records, down to $450 \mathrm{~m}$, are anomalous and probably derived from post mortem dislodgement.

\section{Invalidation of previous record in Brazil}

Iniforis turristhomae (Holten, 1802)

Rios (1970, 1975, 1985, 1994, 2009) presented the main records of I. turristhomae for Brazil. Yet, these were questioned by Leal (1991) and Fernandes et al. (2013), who suggested the correct species was Iniforis pseudothomae Rolán \& Fernández-Garcés, 1993. After examining all lots referred to I. turristhomae at the MORG collection, where Dr Rios worked for most of his life, we conclude that almost all of them indeed corresponded to I. pseudothomae, and no shell of I. turristhomae was seen. Hence, the record of I. turristhomae in Brazil is invalidated, and the southernmost range of this species lies somewhere between Venezuela and the Guyanas.

\section{Summing up species of Triphoridae in Brazil}

Data about geographical and bathymetric ranges of species occurring in Brazil are compiled in Table 2. Maps are provided for each species (Figs 25-81). 
Table 2 (continued on next two pages). Geographical and bathymetric range of triphorids from Brazil. New geographical records and/or extensions of depth range are underlined. The bathymetric range comprises all records of the species, including "Caribbean" ones, but not including very worn shells or discrepant records. Species of the "pseudo Inella" group are indicated as "Inella" (between quotation marks). References in Brazil: 1 = Simone (2006); 2 = Fernandes \& Pimenta (2011); 3 = Fernandes et al. (2013); 4 =Fernandes (2014); 5 = Fernandes \& Pimenta (2014); 6 = Fernandes \& Pimenta (2015); 7 = Fernandes \& Pimenta (2019b); $8=$ Fernandes \& Pimenta (2019a); $9=$ Fernandes et al. in prep.

\begin{tabular}{|c|c|c|c|}
\hline Species & Geographical range & Bathymetric range & $\begin{array}{c}\text { References in } \\
\text { Brazil }\end{array}$ \\
\hline $\begin{array}{l}\text { Metaxia excelsa } \\
\text { Faber \& Moolenbeek, } 1991\end{array}$ & $\begin{array}{l}\text { USA: Florida to Texas; Caribbean; Brazil: } \\
\text { Amapá to Rio de Janeiro, Fernando de } \\
\text { Noronha, Vitória-Trindade }\end{array}$ & $1 \mathrm{~m}$ to $147 \mathrm{~m}$ & 2,8 \\
\hline $\begin{array}{l}\text { Metaxia gongyloskymnus } \\
\text { Fernandes \& Pimenta, } 2011\end{array}$ & Brazil: Espírito Santo to Rio de Janeiro & $100 \mathrm{~m}$ to $120 \mathrm{~m}$ & 2 \\
\hline $\begin{array}{l}\text { Metaxia prompta } \text { Rolán \& } \\
\text { Fernández-Garcés, } 2008\end{array}$ & $\begin{array}{l}\text { Bermuda; Brazil: Vitória-Trindade. The } \\
\text { previous record from Bahia actually consists } \\
\text { of very worn material }\end{array}$ & $10 \mathrm{~m}$ to $105 \mathrm{~m}$ & 2 \\
\hline $\begin{array}{l}\text { Metaxia rugulosa } \\
\text { (C.B. Adams, 1850) }\end{array}$ & 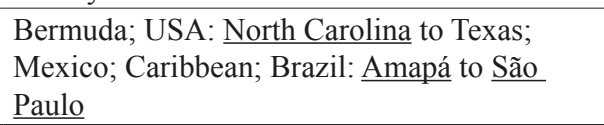 & $0 \mathrm{~m}$ to $198 \mathrm{~m}$ & 2,8 \\
\hline $\begin{array}{l}\text { Metaxia taeniolata } \\
\text { (Dall, 1889) }\end{array}$ & $\begin{array}{l}\text { USA: North Carolina to Texas; Caribbean; } \\
\text { Brazil: Rio Grande do Norte to São Paulo, } \\
\text { Vitória-Trindade. It also occurs in northern } \\
\text { Brazil }\end{array}$ & $4 \mathrm{~m}$ to $101 \mathrm{~m}$ & 2 \\
\hline $\begin{array}{l}\text { Cheirodonta dupliniana (Olsson, } \\
\text { 1916) }\end{array}$ & $\begin{array}{l}\text { USA: Connecticut to Texas; } \text { Mexico; } \\
\text { Caribbean; Brazil: Rio Grande do Norte to } \\
\text { Rio de Janeiro, Fernando de Noronha }\end{array}$ & $\underline{6 \mathrm{~m}}$ to $\underline{183 \mathrm{~m}}$ & 6,8, this study \\
\hline $\begin{array}{l}\text { Coriophora novem } \\
\text { (Nowell-Usticke, 1969) }\end{array}$ & $\begin{array}{l}\text { USA: Florida to Texas; Caribbean; Brazil: } \\
\text { Amapá to Rio de Janeiro, Vitória-Trindade }\end{array}$ & $2 \mathrm{~m}$ to $110 \mathrm{~m}$ & 3,4 , this study \\
\hline $\begin{array}{l}\text { Cosmotriphora arnoldoi } \\
\text { Faber \& Moolenbeek, } 1991\end{array}$ & $\begin{array}{l}\text { USA: Florida to Texas; Mexico; Caribbean; } \\
\text { Brazil: Rio Grande do Norte to } \underline{\text { São Paulo, }} \\
\text { Vitória-Trindade. Worn shells south to } \underline{\text { Santa }} \\
\text { Catarina }\end{array}$ & $20 \mathrm{~m}$ to $155 \mathrm{~m}$ & 3,4, this study \\
\hline $\begin{array}{l}\text { Cosmotriphora melanura } \\
\text { (C.B. Adams, 1850) }\end{array}$ & $\begin{array}{l}\text { Bermuda; USA: North Carolina to Texas; } \\
\text { Mexico; Caribbean; Brazil: Amapá to Rio de } \\
\text { Janeiro, São Pedro e São Paulo, Fernando de } \\
\text { Noronha, Vitória-Trindade. Eastern Atlantic } \\
\text { records require confirmation }\end{array}$ & $\begin{array}{l}0 \mathrm{~m} \text { to } \underline{160 \mathrm{~m}}, \\
\text { discrepant records } \\
\text { down to } \underline{480 \mathrm{~m}}\end{array}$ & $\begin{array}{l}3,4,8, \text { this } \\
\text { study }\end{array}$ \\
\hline $\begin{array}{l}\text { Eutriphora auffenbergi } \\
\text { Rolán \& Lee, } 2008\end{array}$ & USA: Florida; Mexico; Brazil: Bahia & $\begin{array}{l}5 \mathrm{~m} \text { to } \underline{122 \mathrm{~m}}, \\
\text { discrepant records } \\
\text { down to } 274 \mathrm{~m}\end{array}$ & This study \\
\hline $\begin{array}{l}\text { Eutriphora costai } \\
\text { Fernandes \& Pimenta, } 2015\end{array}$ & Brazil: Bahia to Rio de Janeiro & $40 \mathrm{~m}$ to $112 \mathrm{~m}$ & 6 \\
\hline $\begin{array}{l}\text { Inella apexbilirata Rolán \& } \\
\text { Fernández-Garcés, } 2008\end{array}$ & Bahamas; Brazil: Espírito Santo to São Paulo & $69 \mathrm{~m}$ to $300 \mathrm{~m}$ & 7 \\
\hline $\begin{array}{l}\text { "Inella" differens } \\
\text { Rolán \& Lee, } 2008\end{array}$ & $\begin{array}{l}\text { USA: Florida to Louisiana; Brazil: Espírito } \\
\text { Santo to Rio de Janeiro }\end{array}$ & $58 \mathrm{~m}$ to $145 \mathrm{~m}$ & 7 \\
\hline $\begin{array}{l}\text { "Inella" euconfio } \\
\text { Fernandes \& Pimenta, } 2019\end{array}$ & Brazil: Rio de Janeiro to São Paulo & $91 \mathrm{~m}$ to $160 \mathrm{~m}$ & 7 \\
\hline $\begin{array}{l}\text { "Inella" faberi Rolán \& } \\
\text { Fernández-Garcés, } 2008\end{array}$ & $\begin{array}{l}\text { USA: Louisiana; Brazil: Espírito Santo to São } \\
\text { Paulo }\end{array}$ & $46 \mathrm{~m}$ to $143 \mathrm{~m}$ & 7 \\
\hline $\begin{array}{l}\text { "Inella" faceta } \\
\text { Fernandes \& Pimenta, } 2019\end{array}$ & Brazil: Bahia to São Paulo & $32 \mathrm{~m}$ to $160 \mathrm{~m}$ & 7 \\
\hline $\begin{array}{l}\text { "Inella" galo } \\
\text { Fernandes \& Pimenta, } 2019\end{array}$ & Brazil: Rio de Janeiro & $25 \mathrm{~m}$ to $48 \mathrm{~m}$ & 7 \\
\hline
\end{tabular}


Table 2 (continued). Geographical and bathymetric range of triphorids from Brazil.

\begin{tabular}{|c|c|c|c|}
\hline Species & Geographical range & Bathymetric range & $\begin{array}{c}\text { References in } \\
\text { Brazil } \\
\end{array}$ \\
\hline $\begin{array}{l}\text { "Inella" leucocephala } \\
\text { Fernandes \& Pimenta, } 2019\end{array}$ & Brazil: Espírito Santo to Rio de Janeiro & $33 \mathrm{~m}$ to $80 \mathrm{~m}$ & 7 \\
\hline $\begin{array}{l}\text { "Inella" maculata } \\
\text { Fernandes \& Pimenta, } 2019\end{array}$ & Brazil: Espírito Santo to Rio de Janeiro & $51 \mathrm{~m}$ to $105 \mathrm{~m}$ & 7 \\
\hline $\begin{array}{l}\text { "Inella" vanilla } \\
\text { Fernandes \& Pimenta, } 2019\end{array}$ & Brazil: Amapá to Pará & $25 \mathrm{~m}$ to $160 \mathrm{~m}$ & 7 \\
\hline Inella sp. 1 & Brazil: Espírito Santo to Rio de Janeiro & $65 \mathrm{~m}$ to $80 \mathrm{~m}$ & 7 \\
\hline "Inella" sp. 2 & $\begin{array}{l}\text { Brazil: Rio de Janeiro to São Paulo, worn } \\
\text { shells north to Bahia }\end{array}$ & $47 \mathrm{~m}$ to $160 \mathrm{~m}$ & 7 \\
\hline “Inella" sp. 3 & Brazil: São Paulo to Rio Grande do Sul & $50 \mathrm{~m}$ to $450 \mathrm{~m}$ & 7 \\
\hline "Inella" sp. 4 & Brazil: Amapá to Espírito Santo & $33 \mathrm{~m}$ to $74 \mathrm{~m}$ & 7 \\
\hline $\begin{array}{l}\text { Iniforis carmelae Rolán \& } \\
\text { Fernández-Garcés, } 1993\end{array}$ & $\begin{array}{l}\text { Cuba; Brazil: Maranhão to Rio Grande do } \\
\text { Norte, Vitória-Trindade }\end{array}$ & $5 \mathrm{~m}$ to $82 \mathrm{~m}$ & 3 , this study \\
\hline $\begin{array}{l}\text { Iniforis pseudothomae Rolán \& } \\
\text { Fernández-Garcés, } 1993\end{array}$ & $\begin{array}{l}\text { Caribbean; Brazil: Amapá to Rio de Janeiro, } \\
\text { Vitória-Trindade }\end{array}$ & $\begin{array}{l}5 \mathrm{~m} \text { to } \underline{98 \mathrm{~m}}, \text { worn } \\
\text { shells down to } 300 \mathrm{~m}\end{array}$ & $\begin{array}{l}3,4,8, \text { this } \\
\text { study }\end{array}$ \\
\hline Isotriphora leo sp. nov. & Brazil: Trindade Island & $\underline{4 \mathrm{~m}}$ to $\underline{15 \mathrm{~m}}$ & This study \\
\hline $\begin{array}{l}\text { Isotriphora onca } \\
\text { Fernandes et al., } 2013\end{array}$ & Brazil: Vitória-Trindade & $85 \mathrm{~m}$ to $105 \mathrm{~m}$ & 3 \\
\hline $\begin{array}{l}\text { Isotriphora tigrina } \\
\text { Fernandes et al., } 2013\end{array}$ & $\begin{array}{l}\text { Brazil: Vitória-Trindade. The previous } \\
\text { record from Bahia actually consists of } \\
\text { I. pseudothomae }\end{array}$ & $52 \mathrm{~m}$ to $82 \mathrm{~m}$ & 3 \\
\hline $\begin{array}{l}\text { Isotriphora tricingulata Rolán \& } \\
\text { Fernández-Garcés, } 2015\end{array}$ & Antigua; Guadeloupe; Brazil: Amapá & $\underline{72 \mathrm{~m}}$ to $81 \mathrm{~m}$ & This study \\
\hline Isotriphora uncia sp. nov. & Brazil: Fernando de Noronha, Atol das Rocas & $\underline{12 \mathrm{~m}}$ to $\underline{40 \mathrm{~m}}$ & This study \\
\hline Isotriphora sp. 1 & Brazil: Fernando de Noronha & $\underline{40 \mathrm{~m}}$ to $\underline{45 \mathrm{~m}}$ & This study \\
\hline $\begin{array}{l}\text { Latitriphora albida } \\
\text { (A. Adams, 1854) }\end{array}$ & $\begin{array}{l}\text { Bermuda; USA: Georgia to Florida; Mexico; } \\
\text { Caribbean; Brazil: Rio Grande do Norte to } \\
\text { Rio de Janeiro, Fernando de Noronha, Vitória- } \\
\text { Trindade. } \\
\text { It also occurs in northern Brazil }\end{array}$ & $0 \mathrm{~m}$ to $\underline{107 \mathrm{~m}}$ & $\begin{array}{l}3,4,8, \text { this } \\
\text { study }\end{array}$ \\
\hline $\begin{array}{l}\text { Marshallora ostenta Rolán \& } \\
\text { Fernández-Garcés, } 2008\end{array}$ & $\begin{array}{l}\text { USA: Georgia to Florida; Cuba; } \\
\text { Brazil: Amapá to Rio de Janeiro }\end{array}$ & $\underline{3 \mathrm{~m}}$ to $\underline{92 \mathrm{~m}}$ & 4, this study \\
\hline Marshallora sp. 1 & $\underline{\text { Brazil: Rio de Janeiro }}$ & Beach drift & This study \\
\hline Marshallora spp. & See Fernandes et al., in prep. & $\begin{array}{l}\text { Live specimens } \\
\text { apparently restricted } \\
\text { from intertidal to } 20 \mathrm{~m}\end{array}$ & 9 \\
\hline $\begin{array}{l}\text { Monophorus caracca } \\
\text { (Dall, 1927) comb. nov. }\end{array}$ & USA: Georgia; Brazil: Espírito Santo & $\underline{295 \mathrm{~m}}$ to $805 \mathrm{~m}$ & This study \\
\hline $\begin{array}{l}\text { Monophorus olivaceus } \\
\text { (Dall, 1889) }\end{array}$ & $\begin{array}{l}\text { USA: Florida to Texas; Mexico; Caribbean; } \\
\text { Brazil: Amapá to São Paulo, Fernando de } \\
\text { Noronha, Vitória-Trindade }\end{array}$ & $\begin{array}{l}0 \mathrm{~m} \text { to } \underline{120 \mathrm{~m}}, \\
\text { discrepant records } \\
\text { down to } \underline{260 \mathrm{~m}}\end{array}$ & $\begin{array}{l}3,4,8, \text { this } \\
\text { study }\end{array}$ \\
\hline $\begin{array}{l}\text { Monophorus verecundus } \\
\text { sp. nov. }\end{array}$ & Brazil: Rio Grande do Norte to São Paulo & $\underline{102 \mathrm{~m}}$ to $\underline{141 \mathrm{~m}}$ & This study \\
\hline $\begin{array}{l}\text { Nanaphora leei } \\
\text { Fernandes \& Pimenta, } 2015\end{array}$ & $\begin{array}{l}\text { Brazil: Espírito Santo, Rio de Janeiro. It } \\
\text { requires confirmation from the Caribbean }\end{array}$ & $\underline{10 \mathrm{~m}}$ to $25 \mathrm{~m}$ & 6 \\
\hline $\begin{array}{l}\text { Nanaphora verbernei } \\
\text { (Moolenbeek \& Faber, 1989) }\end{array}$ & $\begin{array}{l}\text { Caribbean; Brazil: Rio Grande do Norte to } \\
\text { Santa Catarina }\end{array}$ & $0 \mathrm{~m}$ to $90 \mathrm{~m}$ & 6,8 \\
\hline Nanaphora sp. 1 & $\underline{\text { Brazil: Rio Grande do Norte }}$ & $\begin{array}{l}\text { Only known from } \\
145 \mathrm{~m}\end{array}$ & This study \\
\hline
\end{tabular}


Table 2 (continued). Geographical and bathymetric range of triphorids from Brazil.

\begin{tabular}{|c|c|c|c|}
\hline Species & Geographical range & Bathymetric range & $\begin{array}{l}\text { References in } \\
\text { Brazil }\end{array}$ \\
\hline $\begin{array}{l}\text { Nototriphora decorata } \\
\text { (C.B. Adams, 1850) }\end{array}$ & $\begin{array}{l}\text { Bermuda; USA: North Carolina to Texas; } \\
\text { Mexico; Caribbean; Brazil: Amapá to Santa } \\
\text { Catarina, Fernando de Noronha, Vitória- } \\
\text { Trindade }\end{array}$ & $\begin{array}{l}0 \mathrm{~m} \text { to } \underline{110 \mathrm{~m}}, \\
\text { discrepant records } \\
\text { down to } \underline{450 \mathrm{~m}}\end{array}$ & $\begin{array}{l}3,4,8, \text { this } \\
\text { study }\end{array}$ \\
\hline $\begin{array}{l}\text { Sagenotriphora albocaput } \\
\text { sp. nov. }\end{array}$ & $\begin{array}{l}\text { Brazil: Amapá to Rio Grande do Norte, } \\
\text { Fernando de Noronha }\end{array}$ & $\underline{20 \mathrm{~m}}$ to $\underline{72 \mathrm{~m}}$ & This study \\
\hline $\begin{array}{l}\text { Sagenotriphora osclausum } \\
\text { (Rolán \& Fernández-Garcés, } \\
\text { 1995) }\end{array}$ & $\begin{array}{l}\text { USA: North Carolina to Florida; Mexico; } \\
\text { Caribbean; Brazil: Maranhão to São Paulo. It } \\
\text { also occurs in northern Brazil }\end{array}$ & $2 \mathrm{~m}$ to $183 \mathrm{~m}$ & 4,8 , this study \\
\hline Sagenotriphora sp. 1 & Brazil: Amapá & $\underline{72 \mathrm{~m}}$ to $\underline{103 \mathrm{~m}}$ & This study \\
\hline Sagenotriphora sp. 2 & Brazil: Rio de Janeiro & Only known from $\underline{80 \mathrm{~m}}$ & This study \\
\hline $\begin{array}{l}\text { Similiphora intermedia } \\
\text { (C.B. Adams, 1850) }\end{array}$ & $\begin{array}{l}\text { USA: North Carolina to Texas; Mexico; } \\
\text { Caribbean; Brazil: Pará to } \underline{\text { Santa Catarina }}\end{array}$ & $0 \mathrm{~m}$ to $150 \mathrm{~m}$ & 4,8, this study \\
\hline Similiphora lucida sp. nov. & Brazil: Amapá to Rio Grande do Norte & $\underline{20 \mathrm{~m}}$ to $\underline{58 \mathrm{~m}}$ & This study \\
\hline Similiphora sp. 1 & Guyana; Brazil: Amapá & $\underline{45 \mathrm{~m}}$ to $\underline{103 \mathrm{~m}}$ & This study \\
\hline $\begin{array}{l}\text { Strobiligera campista } \\
\text { Fernandes \& Pimenta, } 2019\end{array}$ & Brazil: Rio de Janeiro & $100 \mathrm{~m}$ to $149 \mathrm{~m}$ & 7 \\
\hline $\begin{array}{l}\text { Strobiligera delicata } \\
\text { Fernandes \& Pimenta, } 2014\end{array}$ & Brazil: Espírito Santo to Rio de Janeiro & $607 \mathrm{~m}$ to $940 \mathrm{~m}$ & 5 \\
\hline $\begin{array}{l}\text { Strobiligera dinea } \\
\text { (Dall, 1927) }\end{array}$ & $\begin{array}{l}\text { USA: Georgia; Brazil: Espírito Santo, } \\
\text { Champlain Seamount }\end{array}$ & $607 \mathrm{~m}$ to $940 \mathrm{~m}$ & 7 \\
\hline $\begin{array}{l}\text { Strobiligera gaesona } \\
\text { (Dall, 1927) }\end{array}$ & USA: Georgia; Brazil: Ceará & $240 \mathrm{~m}$ to $805 \mathrm{~m}$ & 7,8 \\
\hline $\begin{array}{l}\text { Strobiligera inaudita } \\
\text { (Rolán \& Lee, 2008) }\end{array}$ & $\begin{array}{l}\text { USA: Florida to Louisiana; Brazil: Espírito } \\
\text { Santo to } \underline{\text { São Paulo }}\end{array}$ & $58 \mathrm{~m}$ to $\underline{163 \mathrm{~m}}$ & 5 \\
\hline $\begin{array}{l}\text { Strobiligera santista } \\
\text { Fernandes \& Pimenta, } 2019\end{array}$ & Brazil: São Paulo & $153 \mathrm{~m}$ to $258 \mathrm{~m}$ & 7 \\
\hline $\begin{array}{l}\text { Strobiligera unicornium } \\
\text { (Simone, 2006) }\end{array}$ & Brazil: Maranhão to Ceará & $240 \mathrm{~m}$ to $274 \mathrm{~m}$ & 1,7 \\
\hline Strobiligera sp. 1 & Brazil: Espírito Santo & $607 \mathrm{~m}$ to $620 \mathrm{~m}$ & 7 \\
\hline Strobiligera sp. 2 & Brazil: Rio Grande do Norte & $102 \mathrm{~m}$ to $108 \mathrm{~m}$ & 7 \\
\hline $\begin{array}{l}\text { Triphora atlantica } \\
\text { Smith, } 1890\end{array}$ & $\begin{array}{l}\text { USA: Florida to Louisiana; Puerto Rico; } \\
\text { Brazil: Amapá to Rio de Janeiro, Fernando } \\
\text { de Noronha, Vitória-Trindade; Saint Helena } \\
\text { Island }\end{array}$ & $\underline{12 \mathrm{~m}}$ to $\underline{150 \mathrm{~m}}$ & 3,4, this study \\
\hline $\begin{array}{l}\text { Triphora charybdis } \\
\text { Fernandes \& Pimenta, } 2015\end{array}$ & $\begin{array}{l}\text { Colombia; } ; \underline{\text { Guyana; }} ; \text { Brazil: Amapá to Rio } \\
\text { Grande do Sul (see above preserved vs worn } \\
\text { material) }\end{array}$ & $\begin{array}{l}80 \mathrm{~m} \text { to } \underline{186 \mathrm{~m}}, \text { worn } \\
\text { shells down to } 450 \mathrm{~m}\end{array}$ & 6 , this study \\
\hline $\begin{array}{l}\text { Triphora ellyae } \\
\text { De Jong \& Coomans, } 1988\end{array}$ & $\begin{array}{l}\text { USA: Florida to Louisiana; Caribbean; Brazil: } \\
\text { Rio Grande do Norte to Santa Catarina, } \\
\text { Vitória-Trindade }\end{array}$ & $\underline{3 \mathrm{~m}}$ to $\underline{110 \mathrm{~m}}$ & 3,4, this study \\
\hline $\begin{array}{l}\text { Triphora elvirae } \\
\text { De Jong \& Coomans, } 1988\end{array}$ & $\begin{array}{l}\text { USA: Florida, Louisiana; Caribbean; Brazil: } \\
\text { Maranhão to Rio de Janeiro, Fernando de } \\
\text { Noronha, } \underline{\text { Atol das Rocas, Vitória-Trindade }}\end{array}$ & $7 \mathrm{~m}$ to $\underline{100 \mathrm{~m}}$ & 3,4, this study \\
\hline $\begin{array}{l}\text { Triphora portoricensis } \\
\text { Rolán \& Redfern, } 2008\end{array}$ & $\begin{array}{l}\text { Caribbean; Brazil: Rio Grande do Norte to } \\
\text { Rio de Janeiro }\end{array}$ & $\underline{23 \mathrm{~m}}$ to $100 \mathrm{~m}$ & 6 \\
\hline $\begin{array}{l}\text { Triphora scylla } \\
\text { Fernandes \& Pimenta, } 2015\end{array}$ & Brazil: Maranhão to Rio de Janeiro & $\underline{20 \mathrm{~m}}$ to $\underline{150 \mathrm{~m}}$ & 6 \\
\hline
\end{tabular}




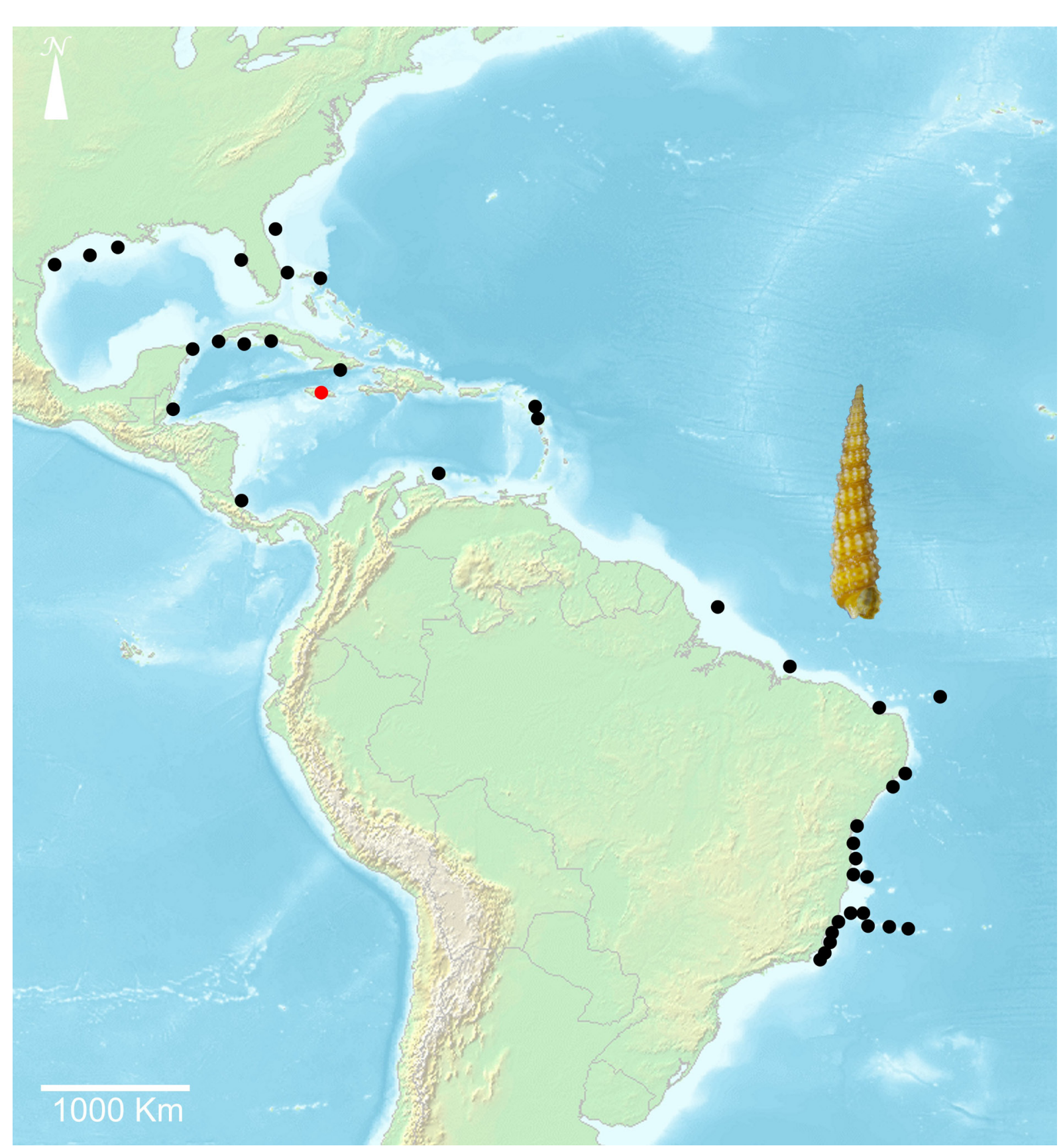

Fig. 25. Distribution map of Metaxia excelsa Faber \& Moolenbeek, 1991; red circle = type locality. 


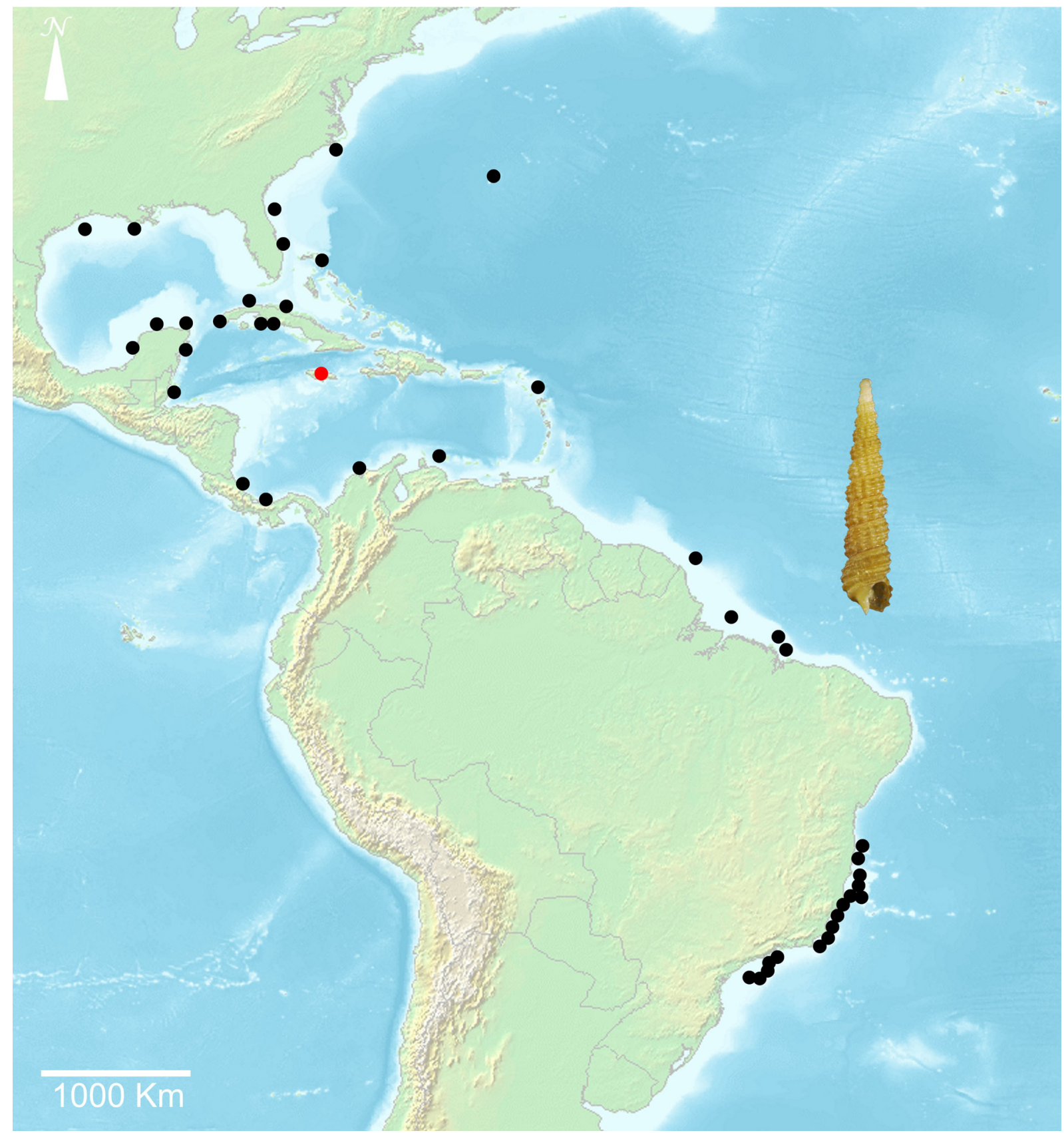

Fig. 26. Distribution map of Metaxia rugulosa (C.B. Adams, 1850); red circle = type locality. 


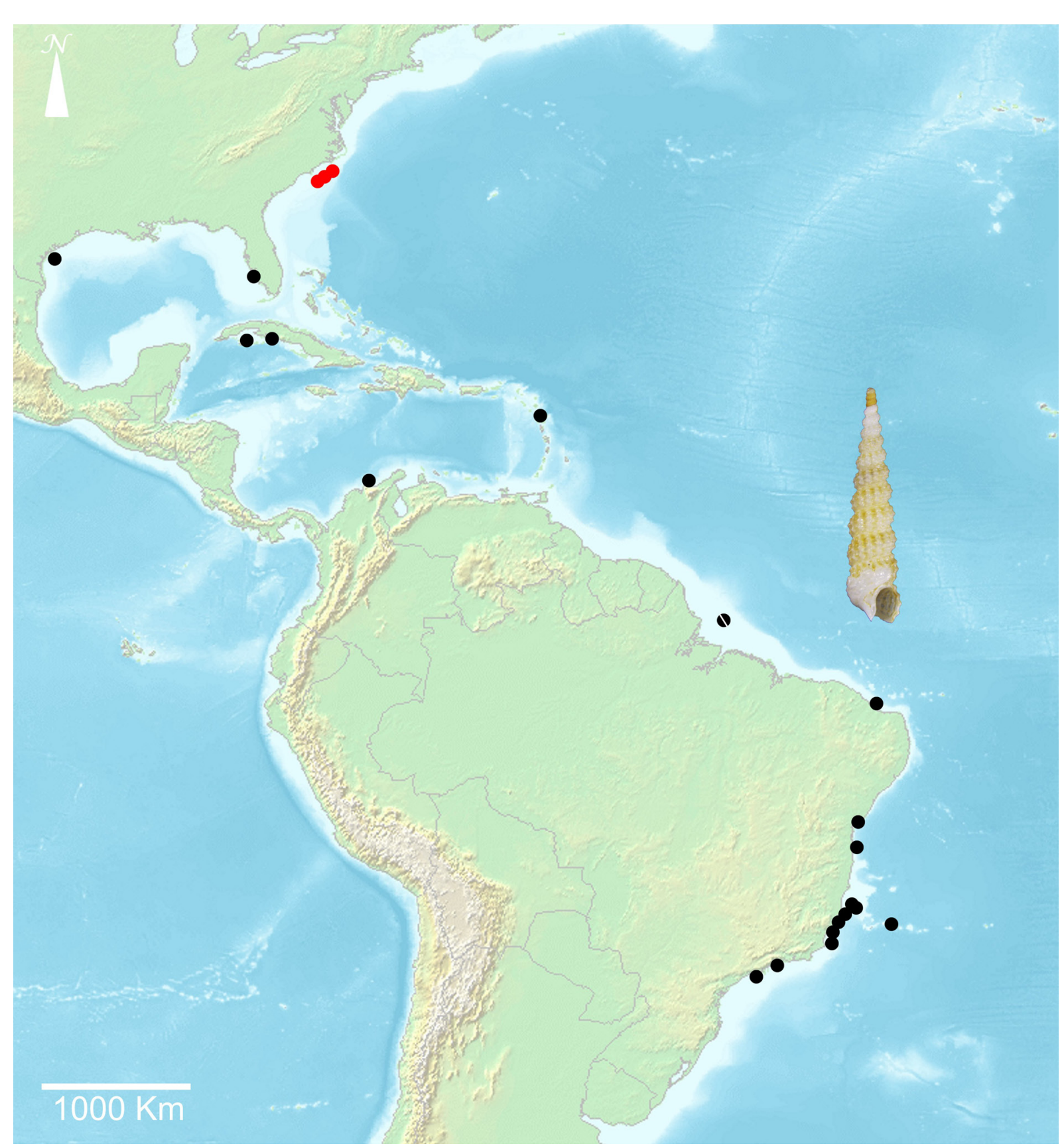

Fig. 27. Distribution map of Metaxia taeniolata (Dall, 1889); red circles = type locality. 


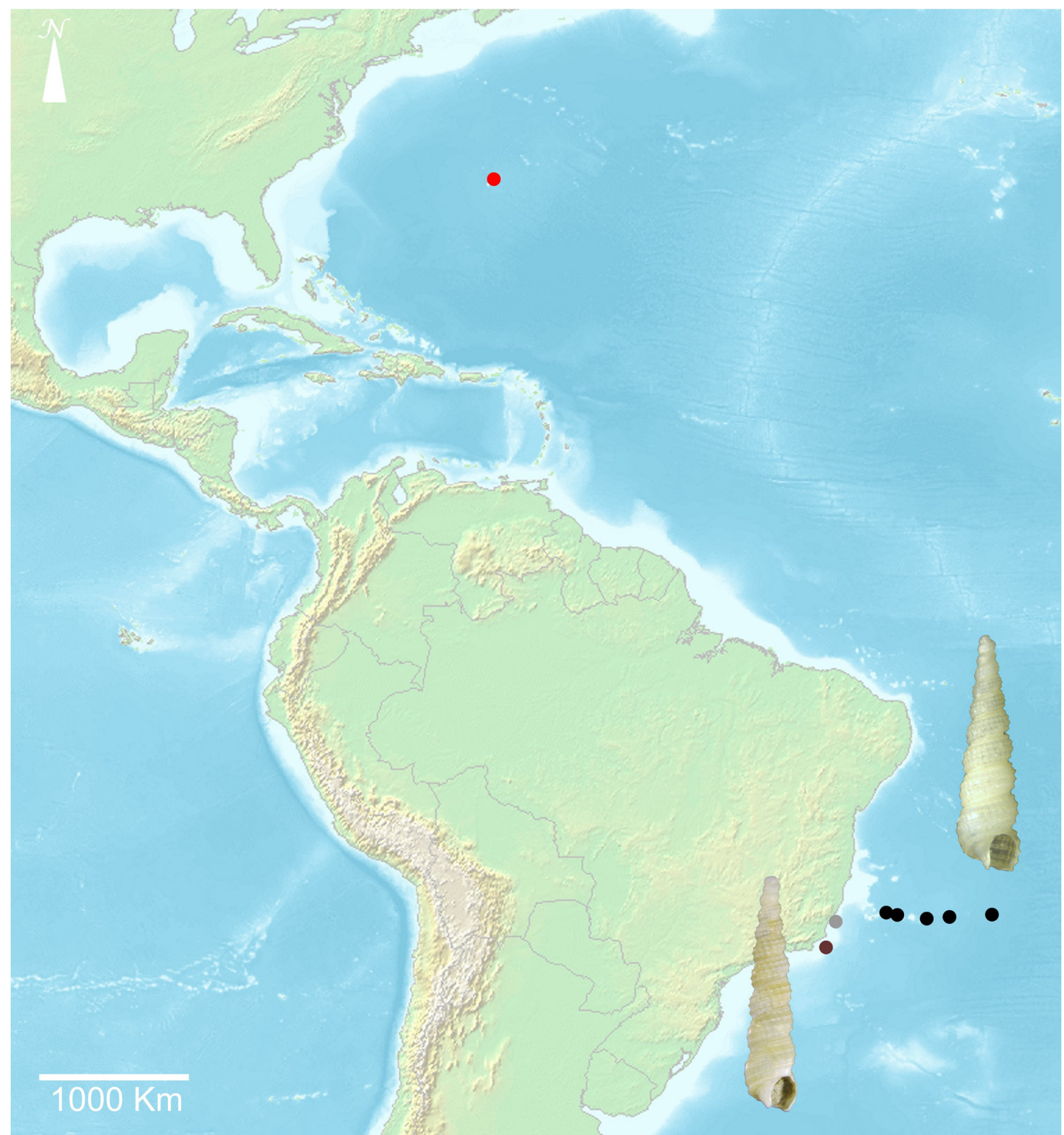

Fig. 28. Distribution map of Metaxia prompta Rolán \& Fernández-Garcés, 2008 (red circle = type locality; black circles = additional localities) and Metaxia gongyloskymnus Fernandes \& Pimenta, 2011 (brown circle = type locality; gray circle $=$ additional locality). 


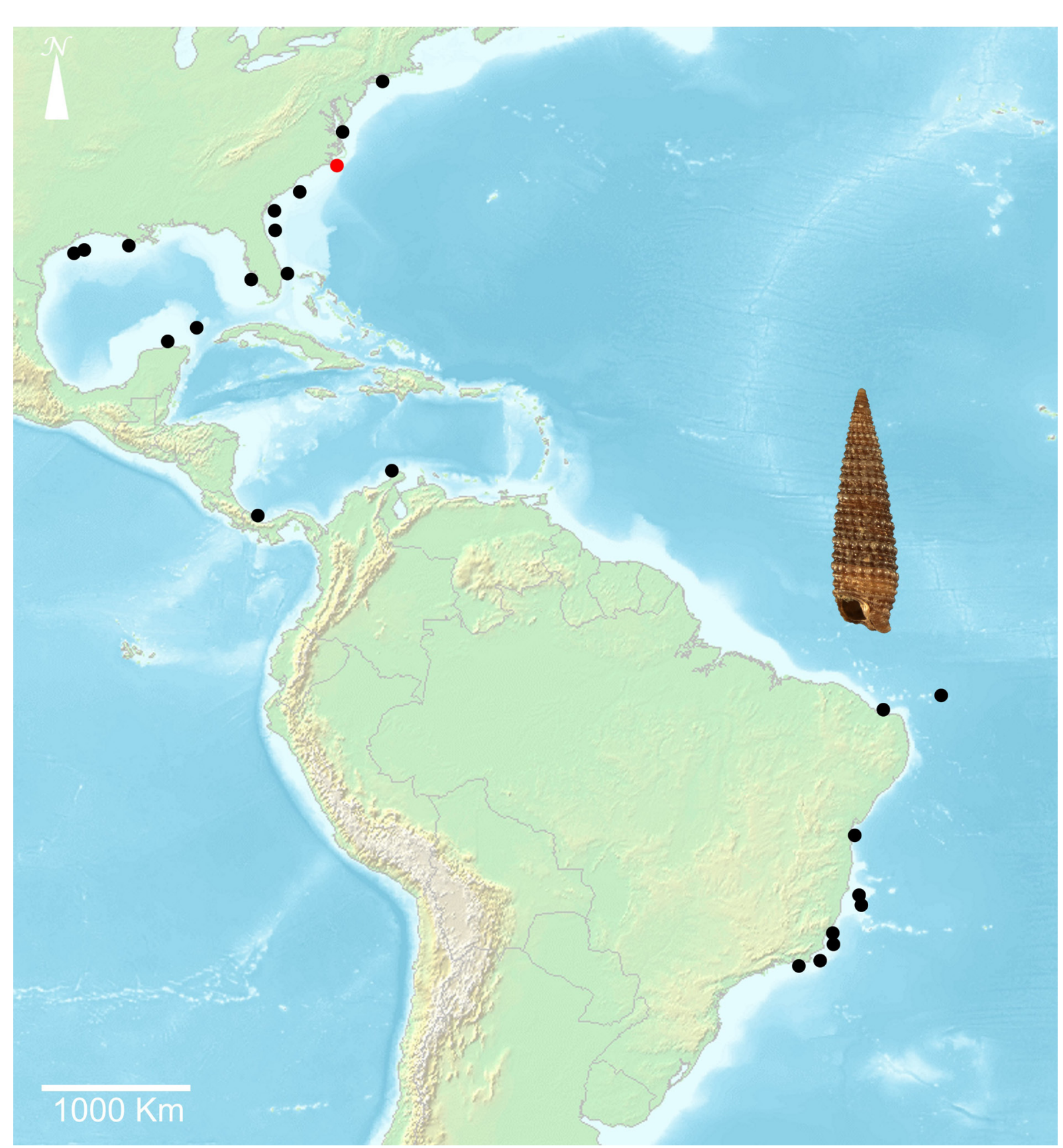

Fig. 29. Distribution map of Cheirodonta dupliniana (Olsson, 1916); red circle = type locality. 


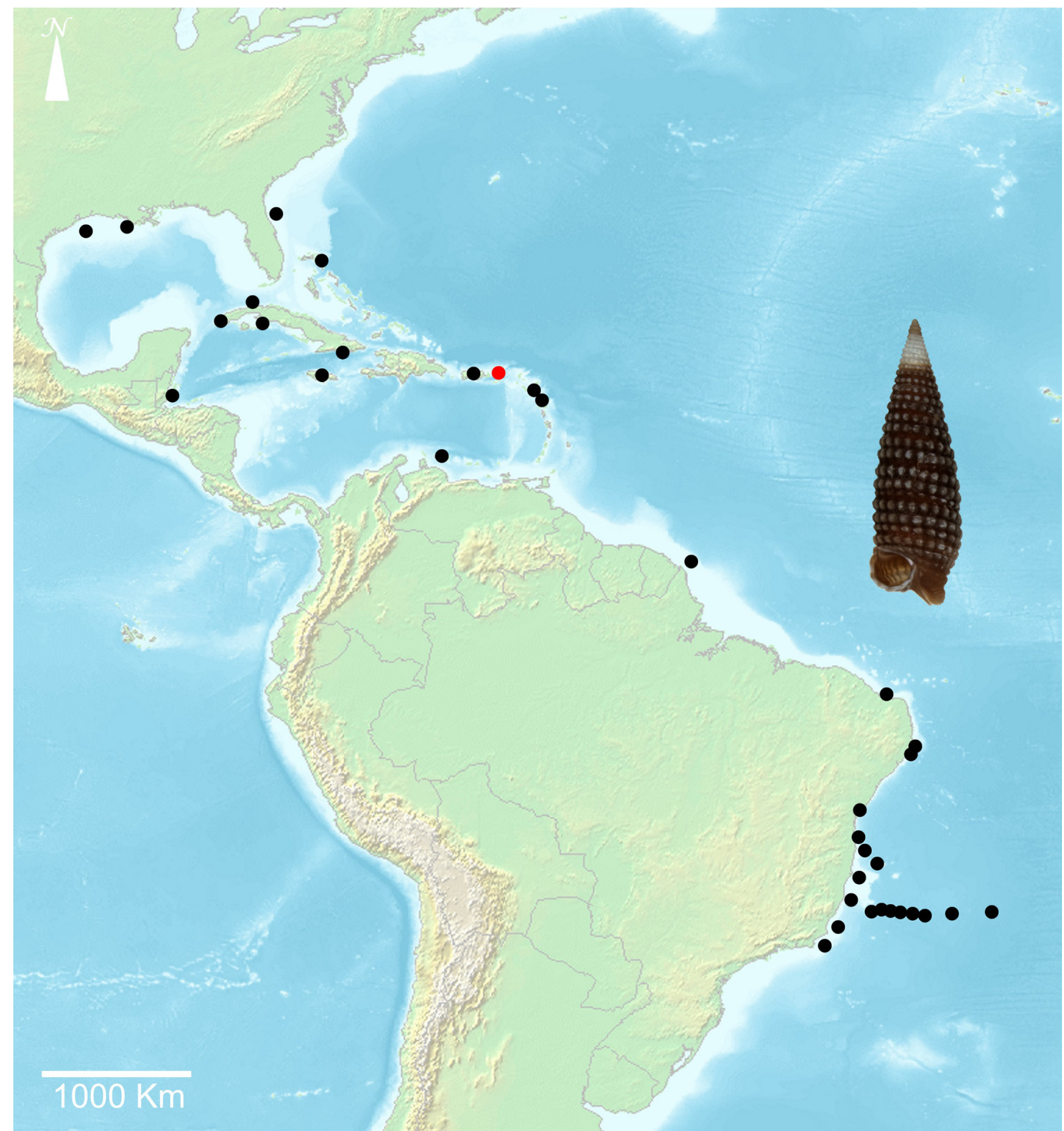

Fig. 30. Distribution map of Coriophora novem (Nowell-Usticke, 1969); red circle = type locality. 


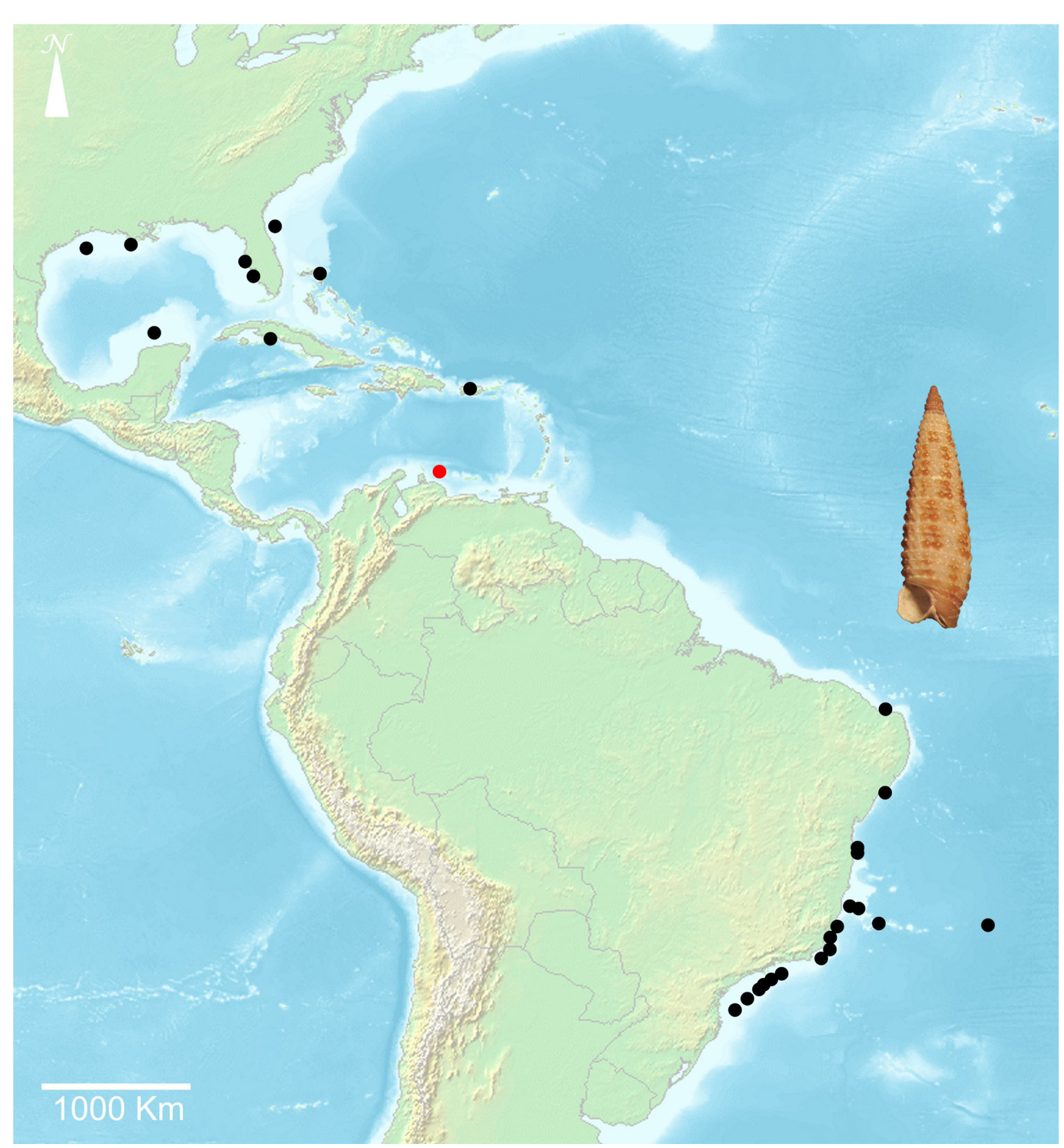

Fig. 31. Distribution map of Cosmotriphora arnoldoi Faber \& Moolenbeek, 1991; red circle = type locality. 


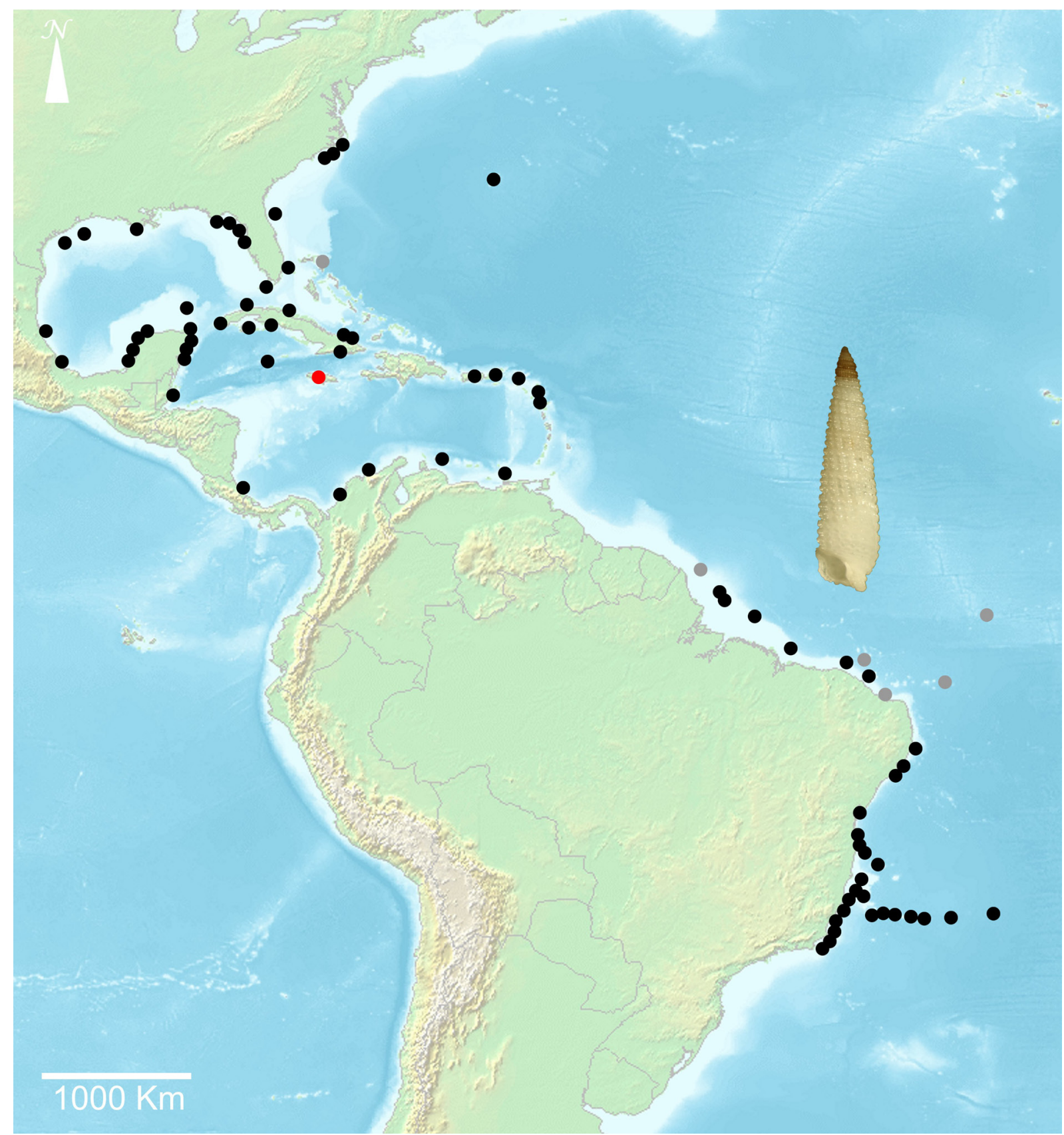

Fig. 32. Distribution map of Cosmotriphora melanura (C.B. Adams, 1850) (red circle = type locality), with gray circles representing the sympatry of $C$. melanura with atypical shells (Cosmotriphora $\mathrm{cf}$. melanura). 


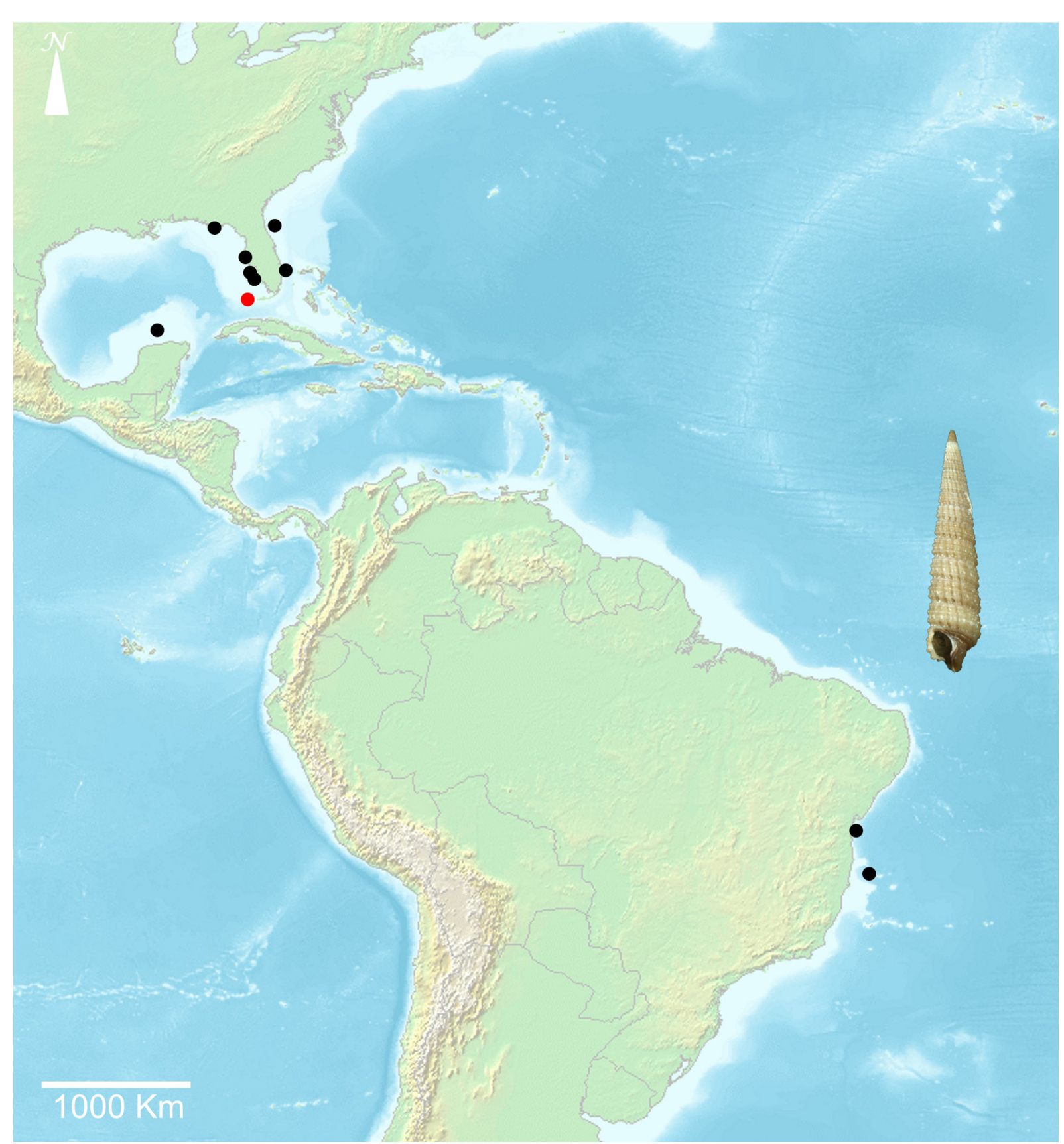

Fig. 33. Distribution map of Eutriphora auffenbergi Rolán \& Lee, 2008; red circle = type locality. 


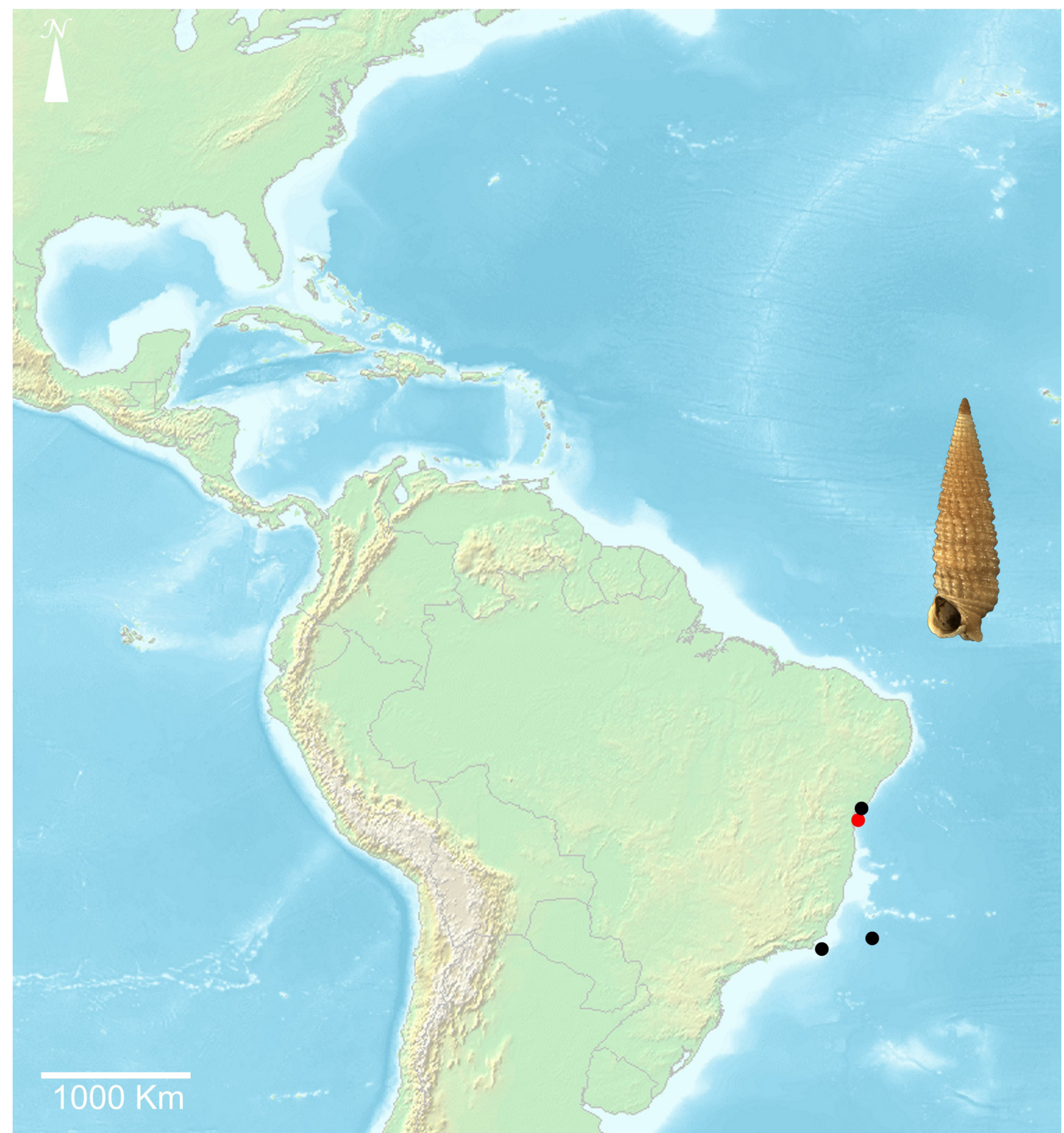

Fig. 34. Distribution map of Eutriphora costai Fernandes \& Pimenta, 2015; red circle = type locality. 


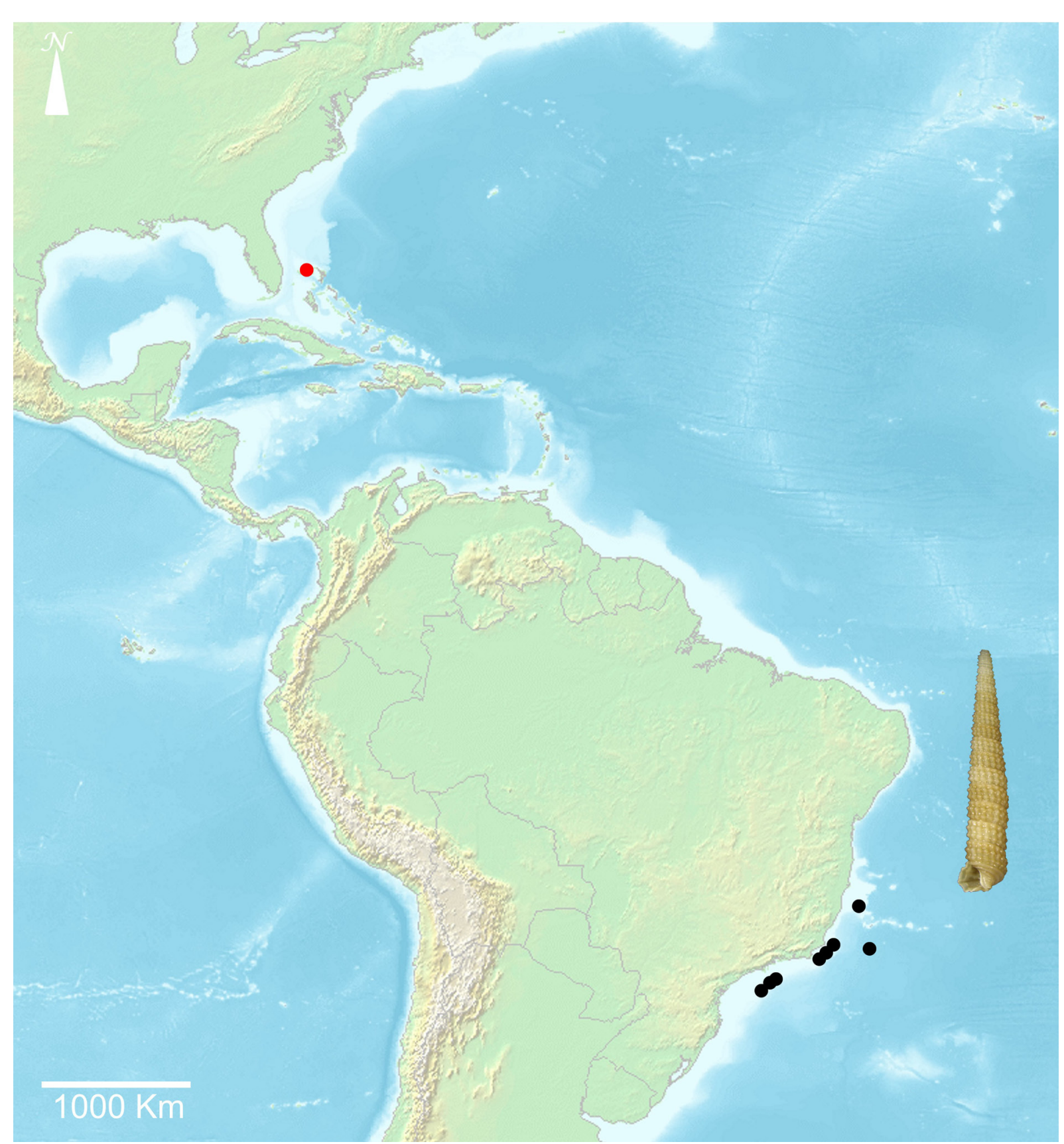

Fig. 35. Distribution map of Inella apexbilirata Rolán \& Fernández-Garcés, 2008; red circle = type locality. 


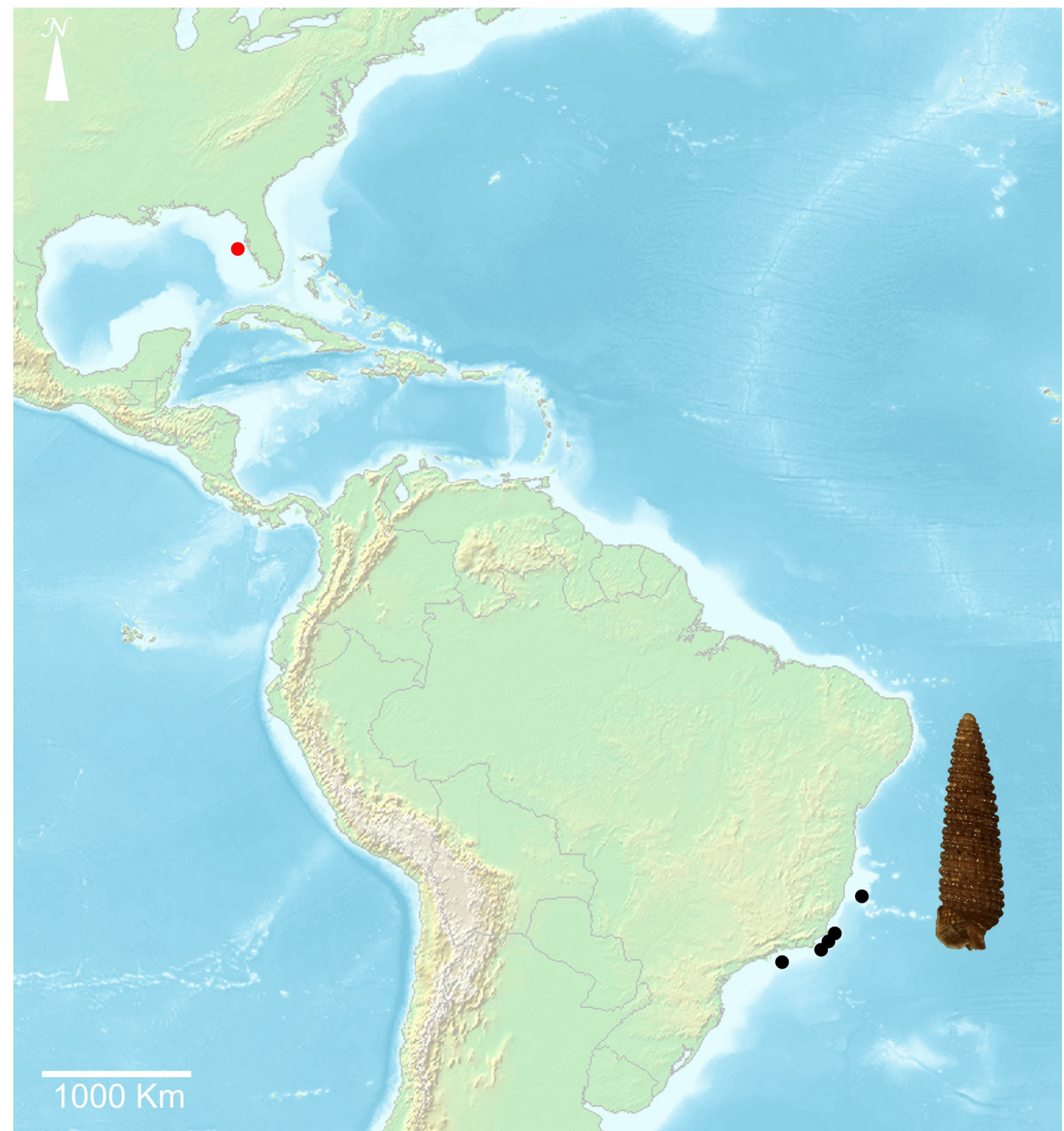

Fig. 36. Distribution map of "Inella" differens Rolán \& Lee, 2008; red circle = type locality. 


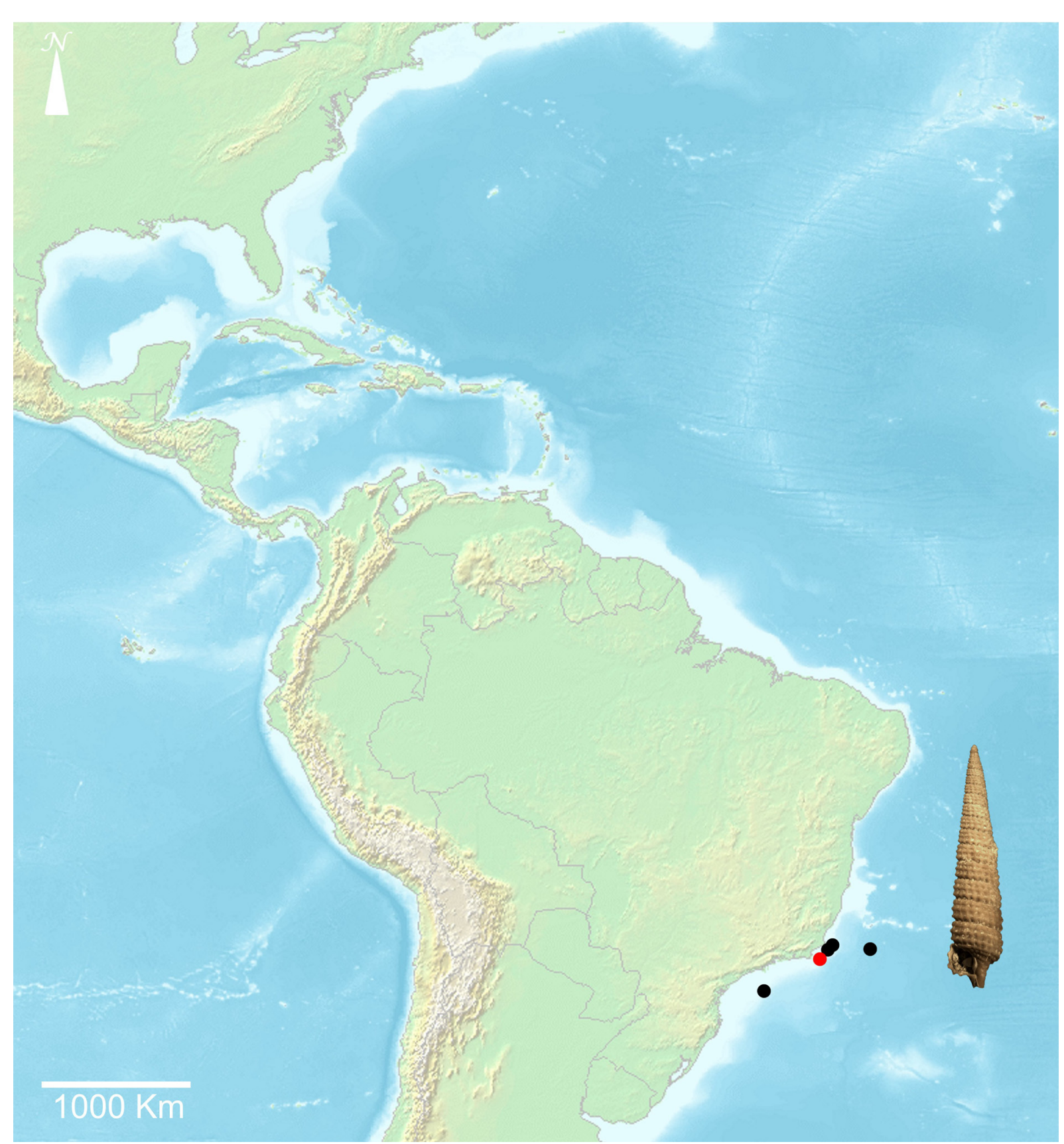

Fig. 37. Distribution map of "Inella" euconfio Fernandes \& Pimenta, 2019; red circle = type locality. 


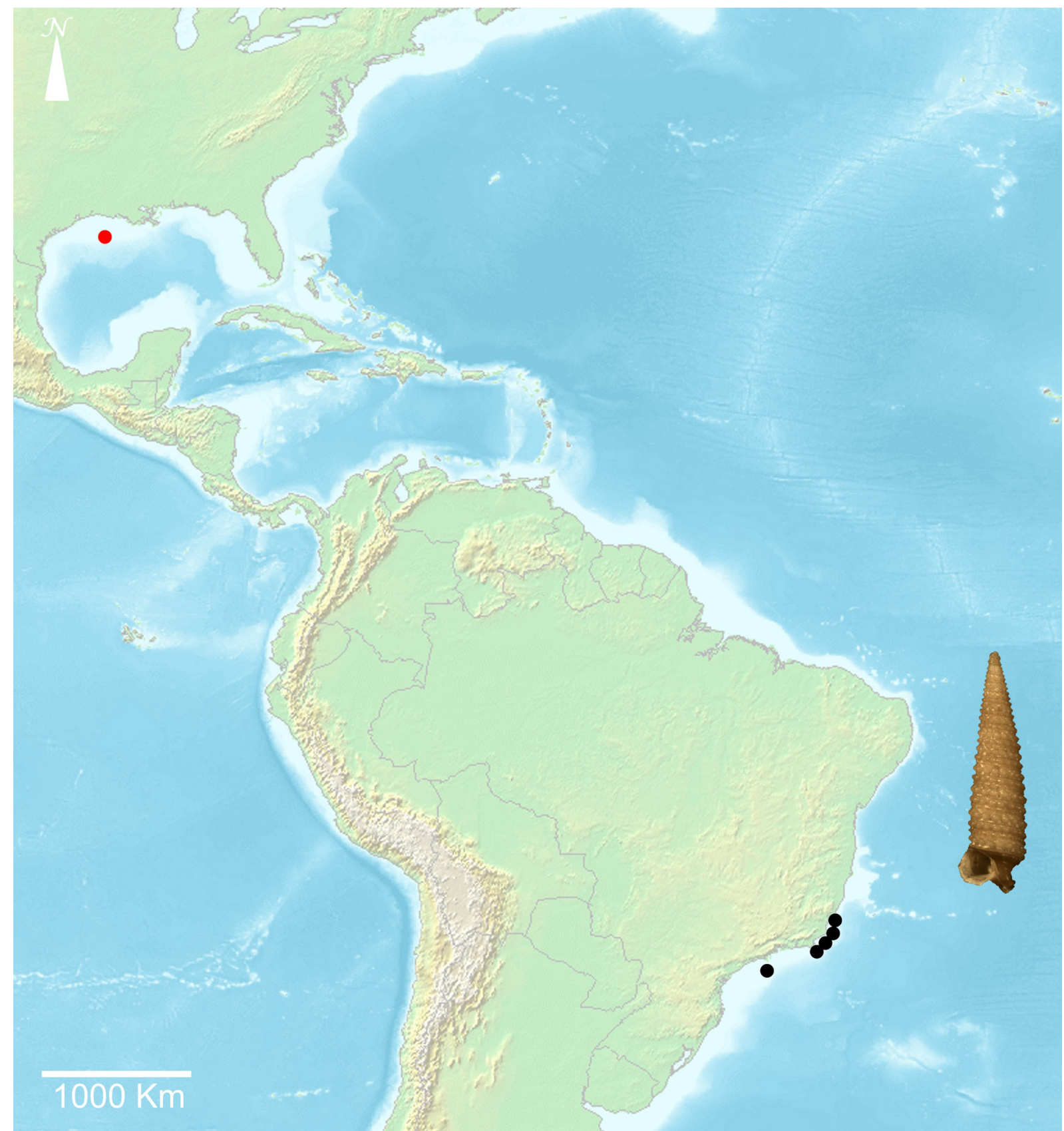

Fig. 38. Distribution map of "Inella" faberi Rolán \& Fernández-Garcés, 2008; red circle = type locality. 


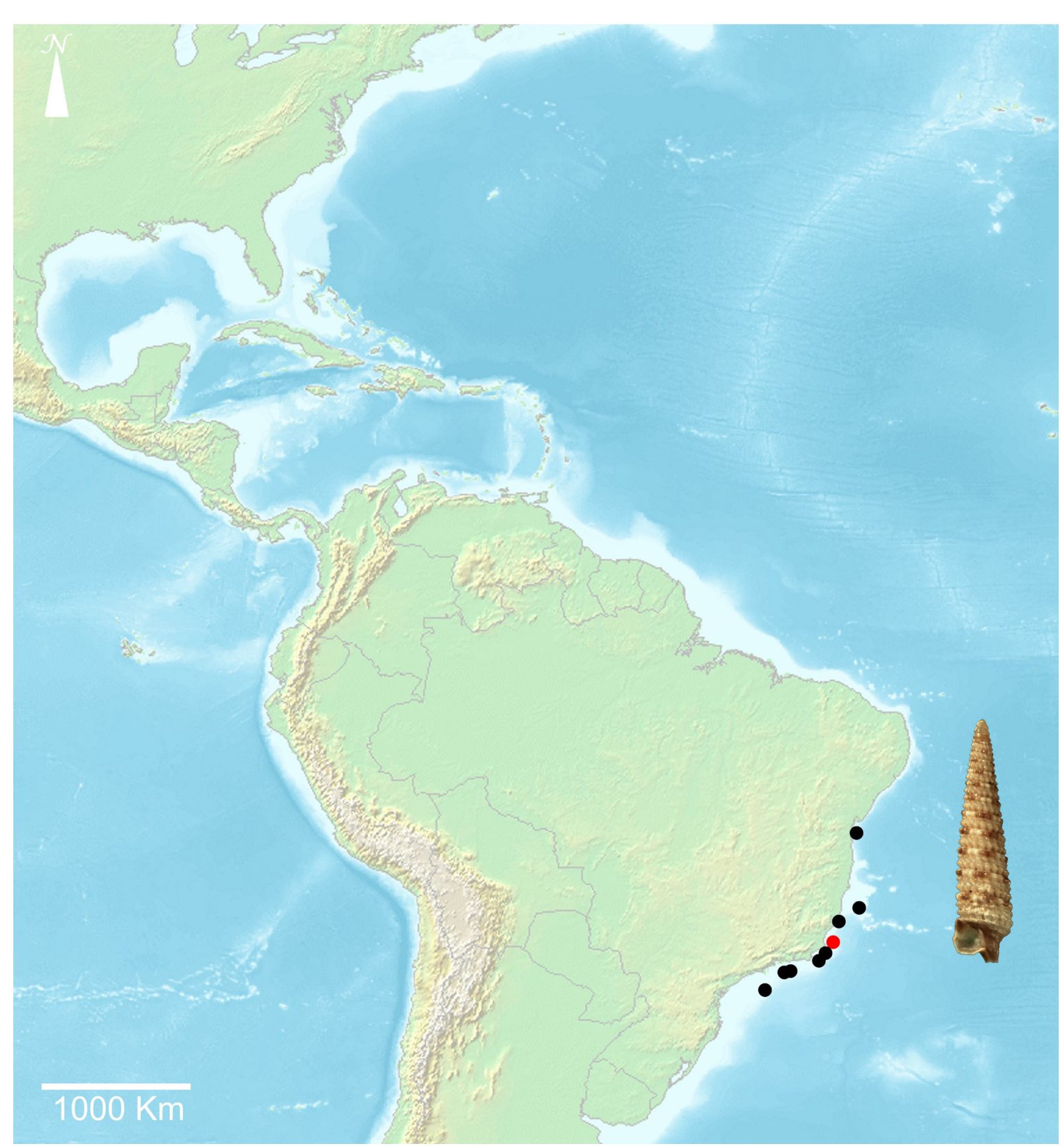

Fig. 39. Distribution map of "Inella" faceta Fernandes \& Pimenta, 2019; red circle = type locality. 


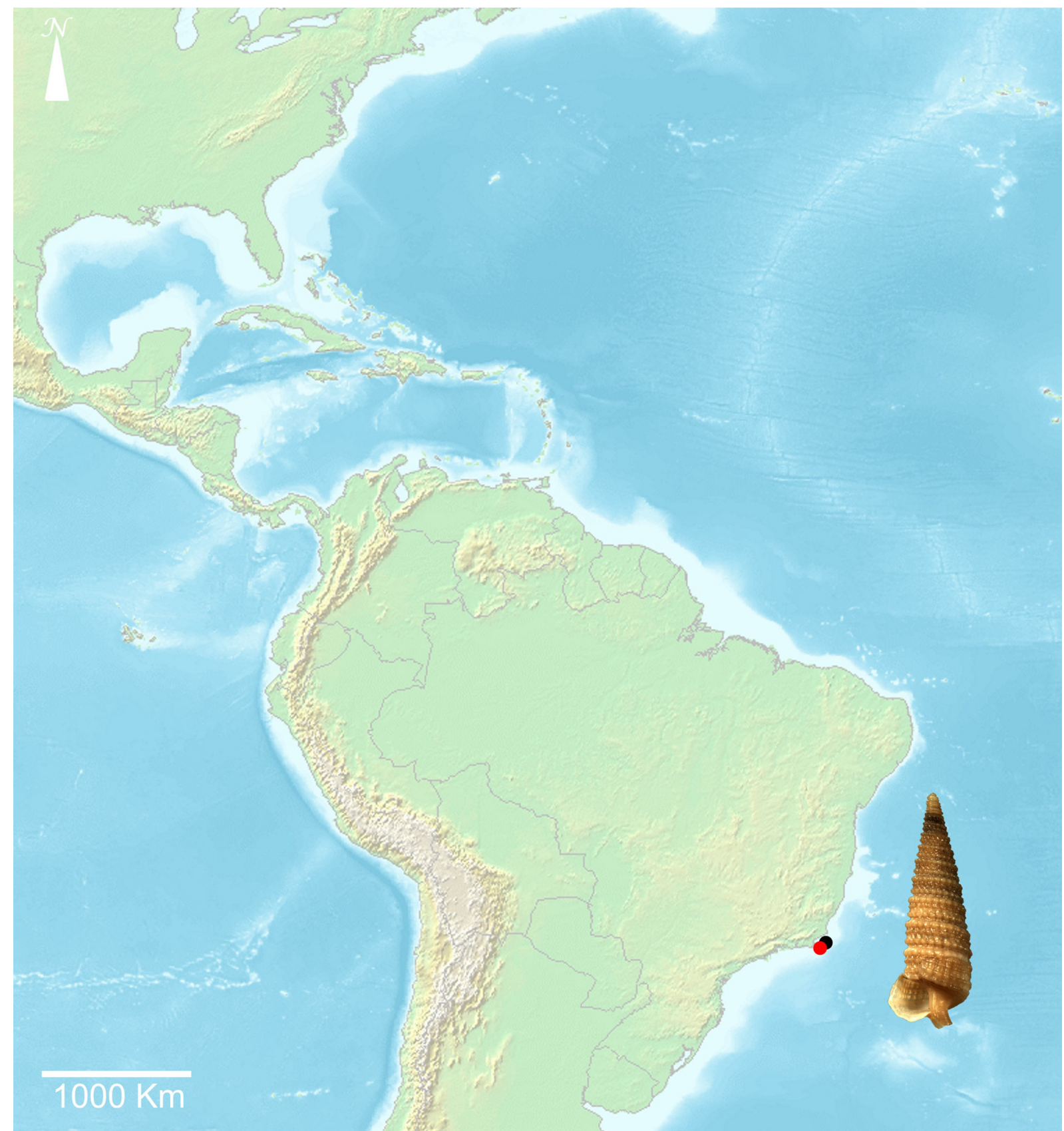

Fig. 40. Distribution map of "Inella" galo Fernandes \& Pimenta, 2019; red circle = type locality. 


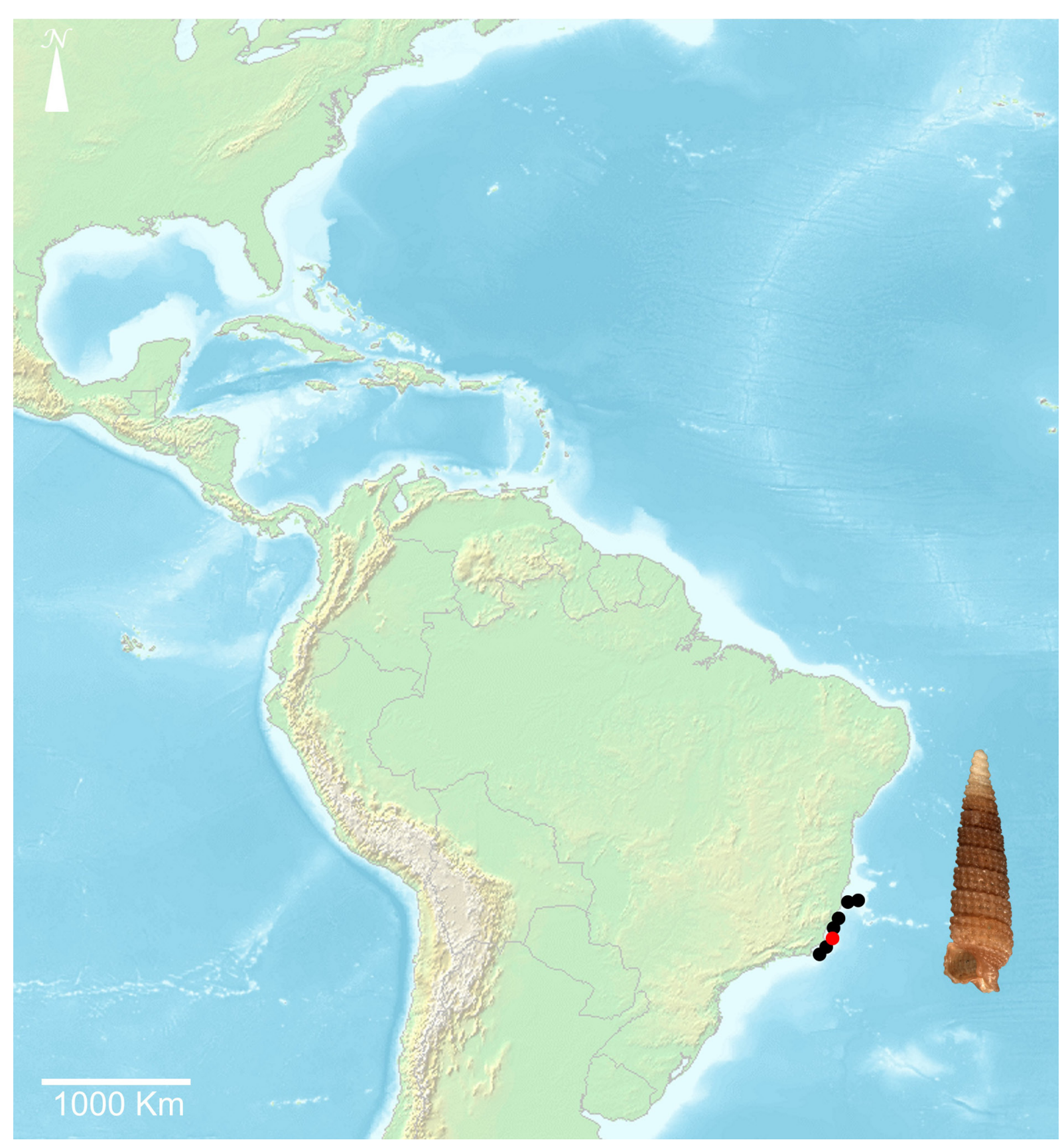

Fig. 41. Distribution map of "Inella" leucocephala Fernandes \& Pimenta, 2019; red circle = type locality. 


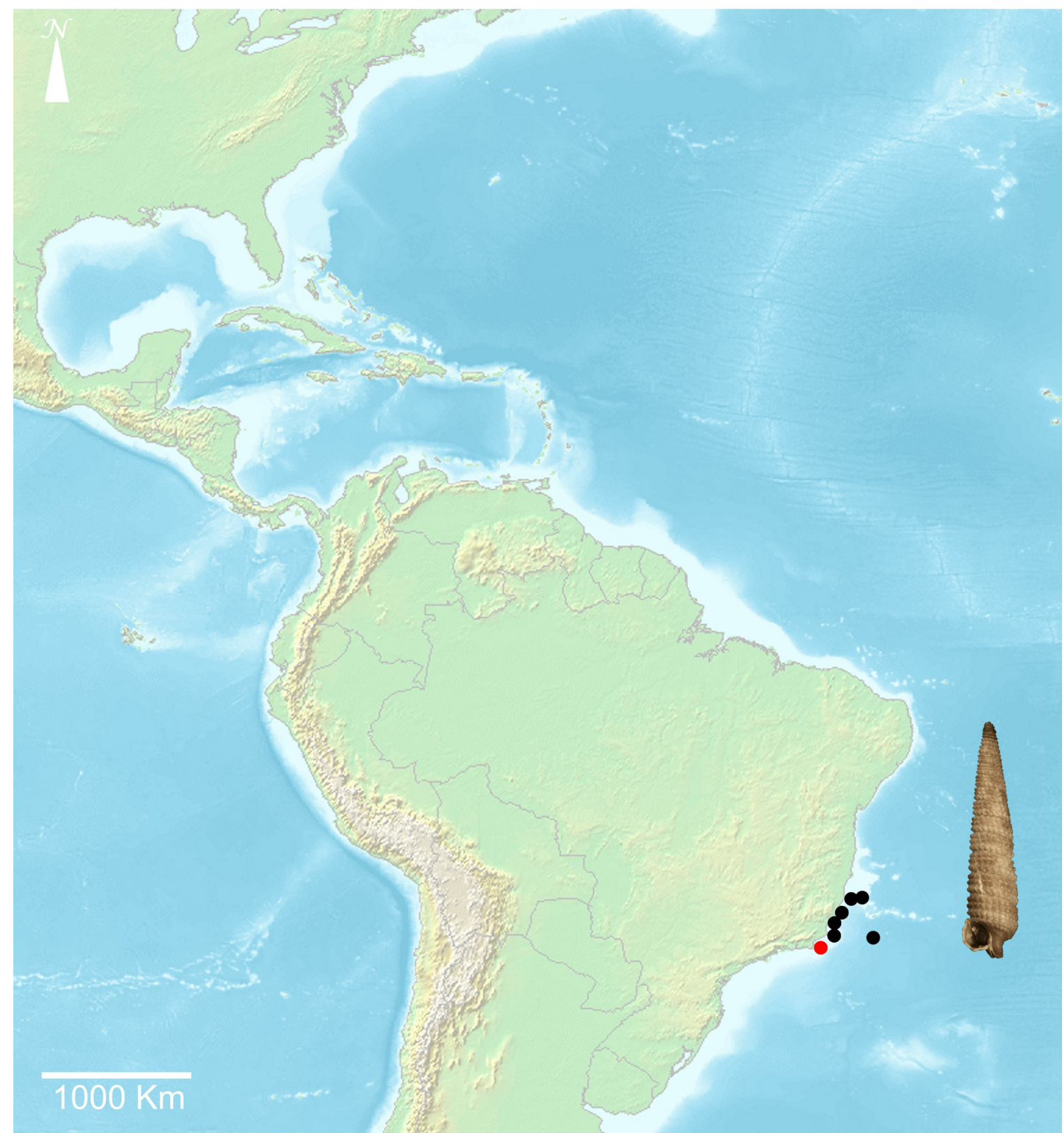

Fig. 42. Distribution map of "Inella" maculata Fernandes \& Pimenta, 2019; red circle = type locality. 


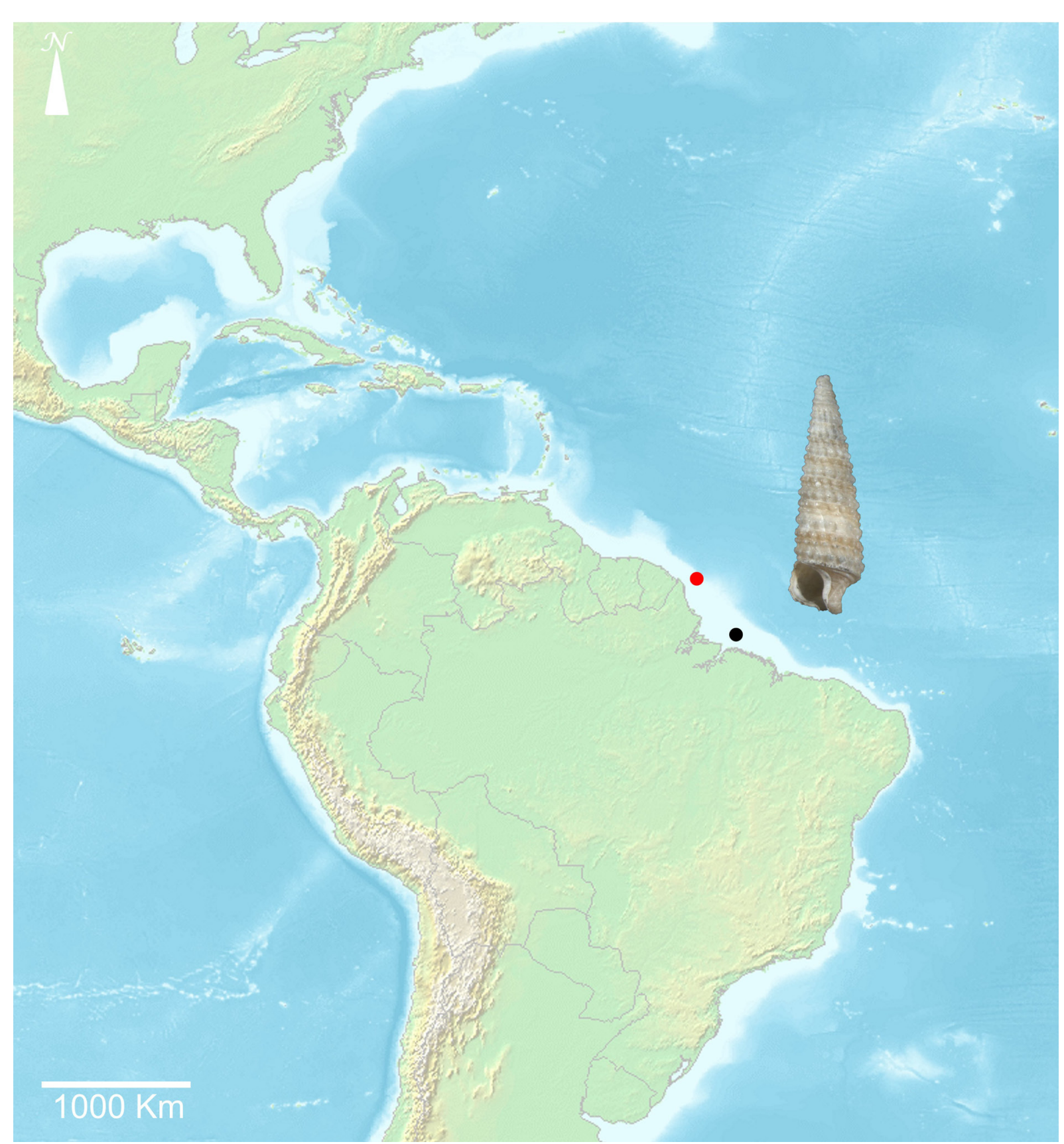

Fig. 43. Distribution map of "Inella" vanilla Fernandes \& Pimenta, 2019; red circle = type locality. 


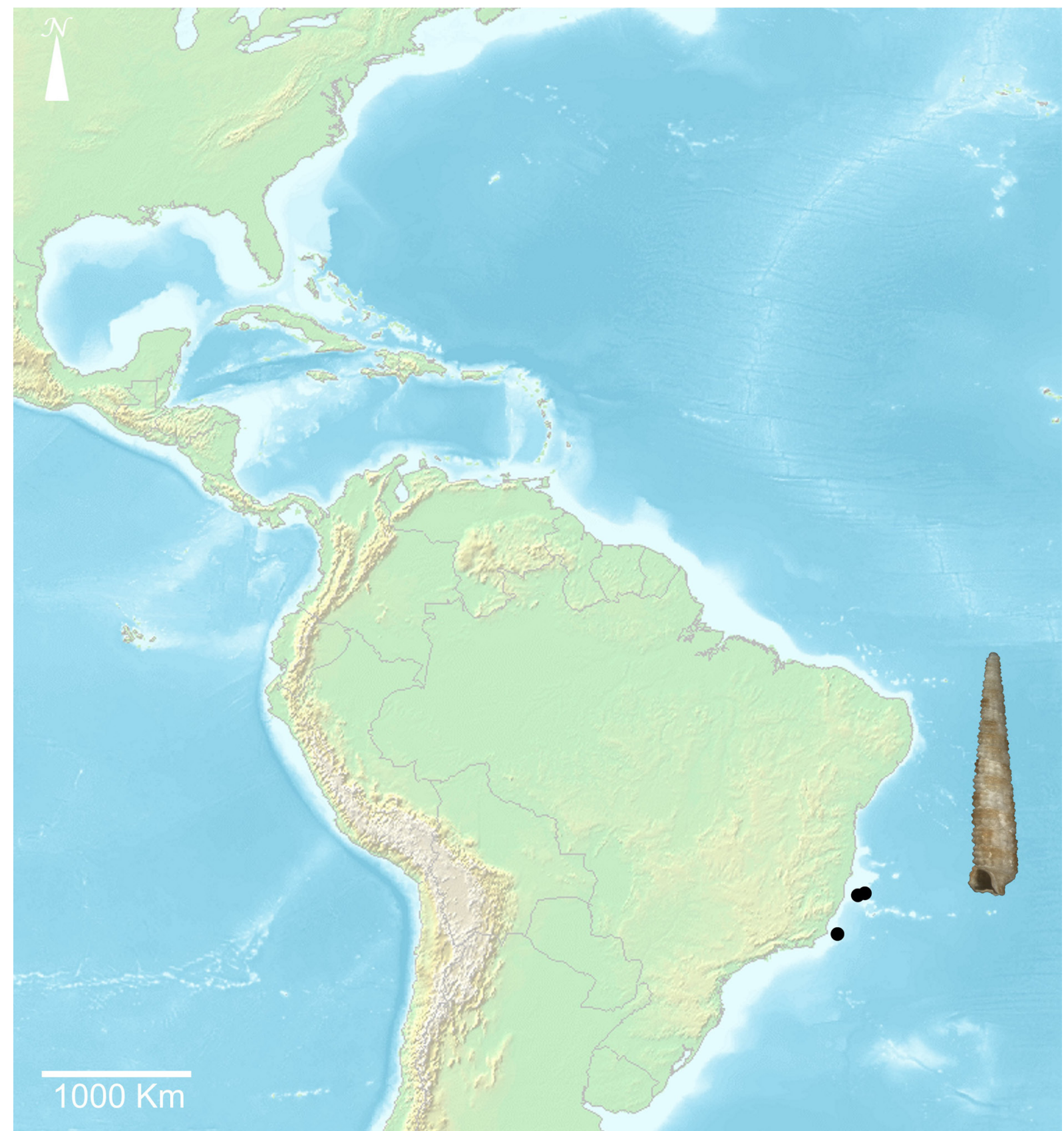

Fig. 44. Distribution map of Inella sp. 1. 


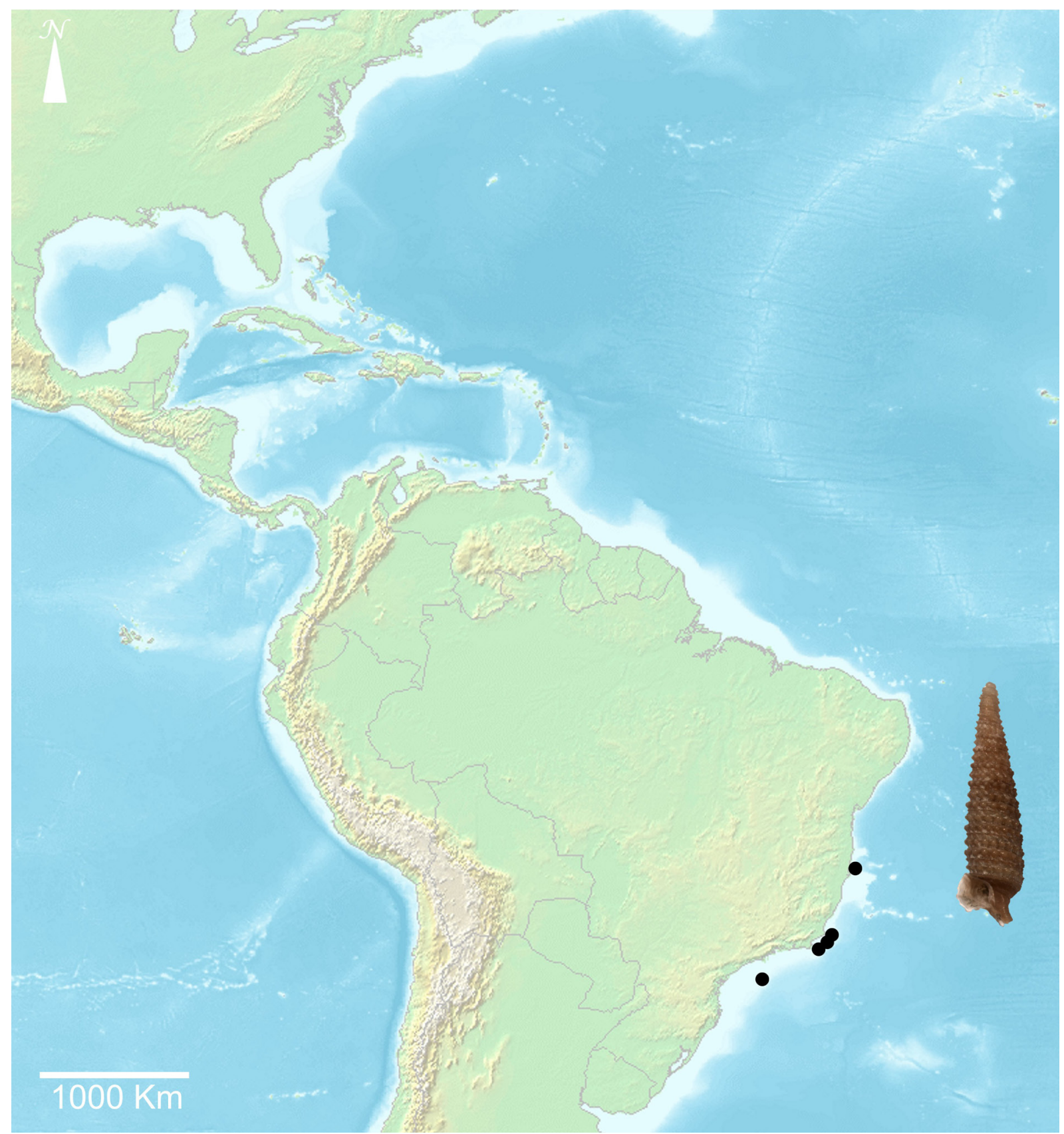

Fig. 45. Distribution map of "Inella" sp. 2. 


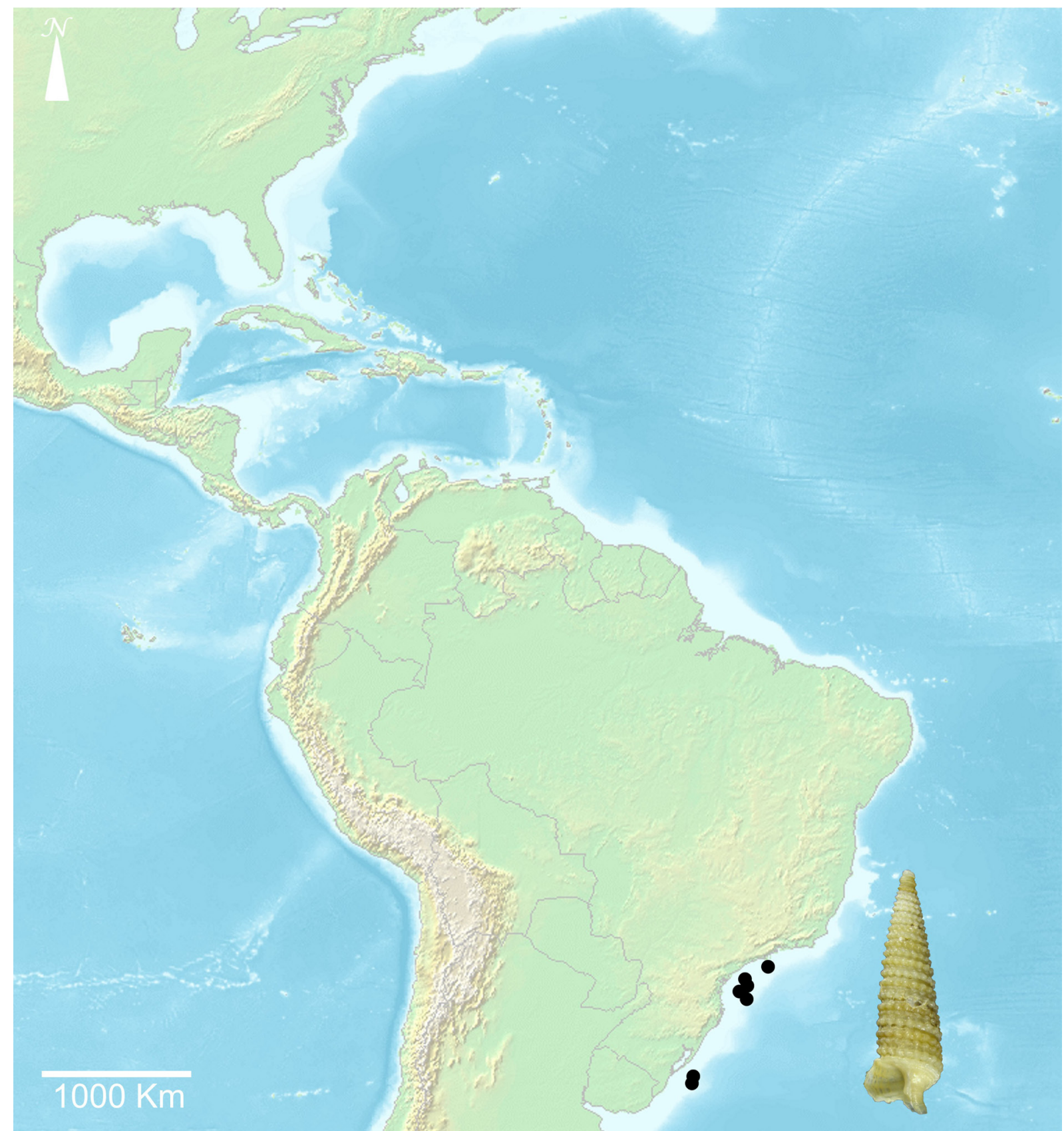

Fig. 46. Distribution map of "Inella" sp. 3. 


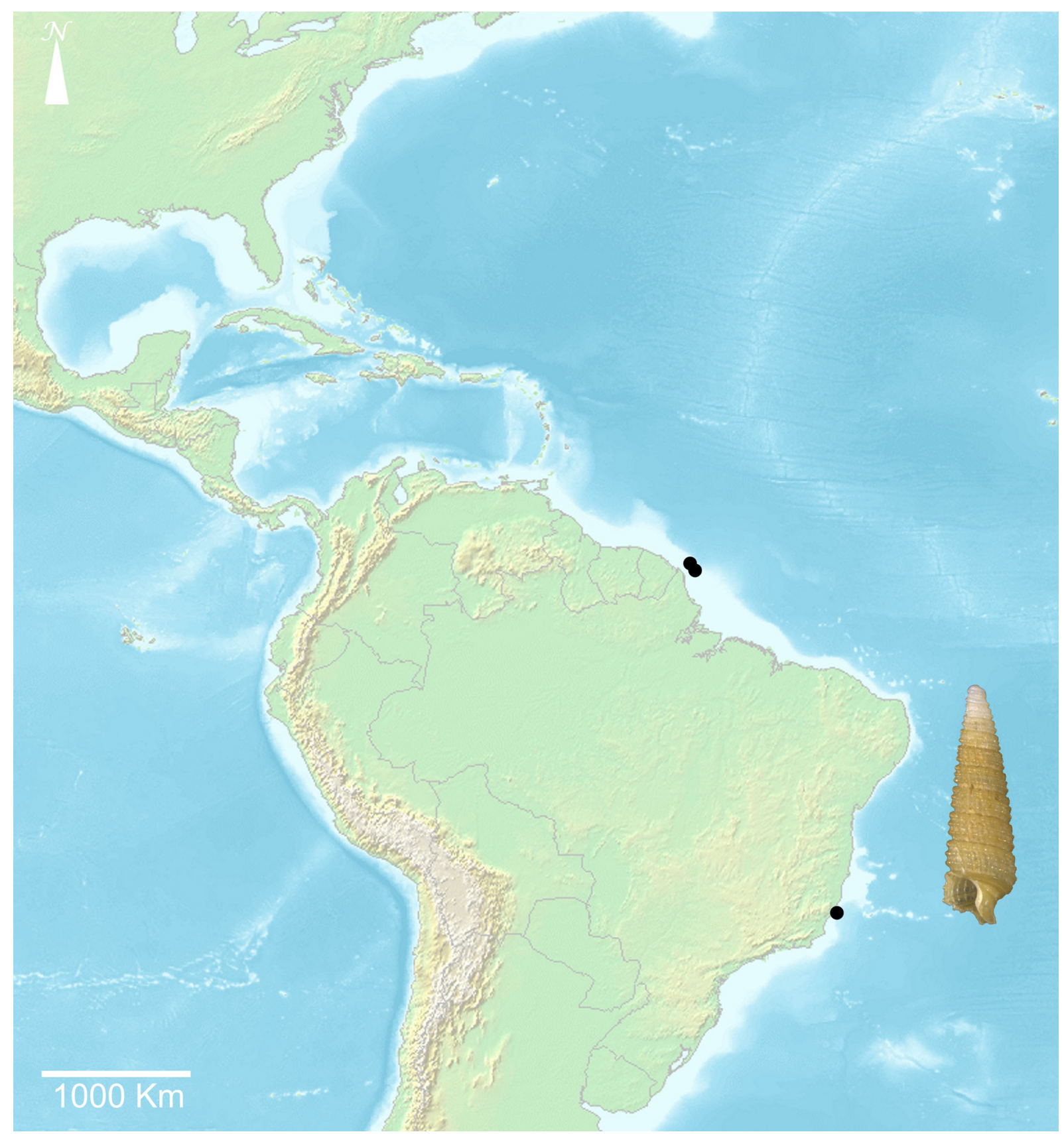

Fig. 47. Distribution map of "Inella" sp. 4. 


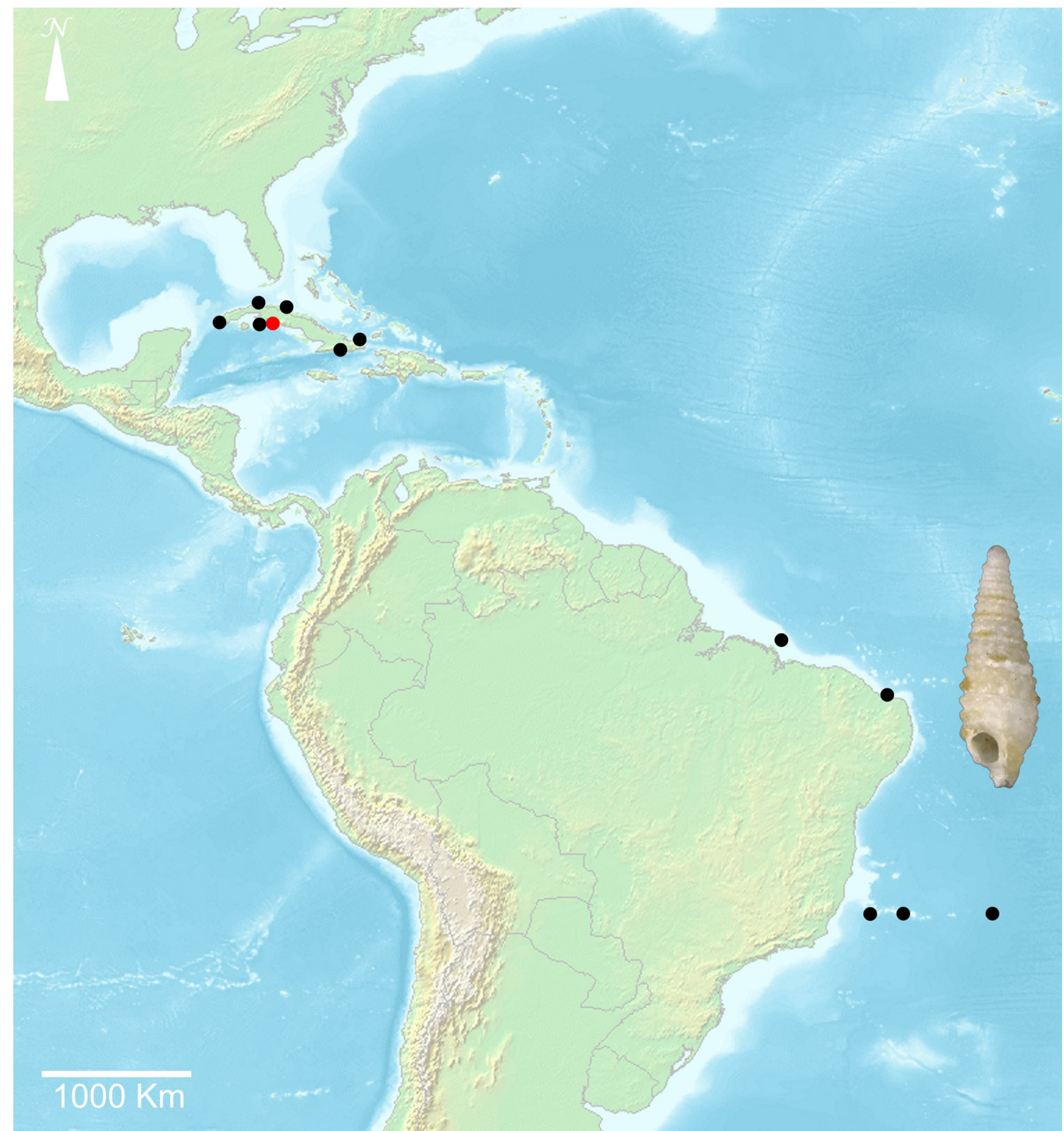

Fig. 48. Distribution map of Iniforis carmelae Rolán \& Fernández-Garcés, 1993; red circle = type locality. 


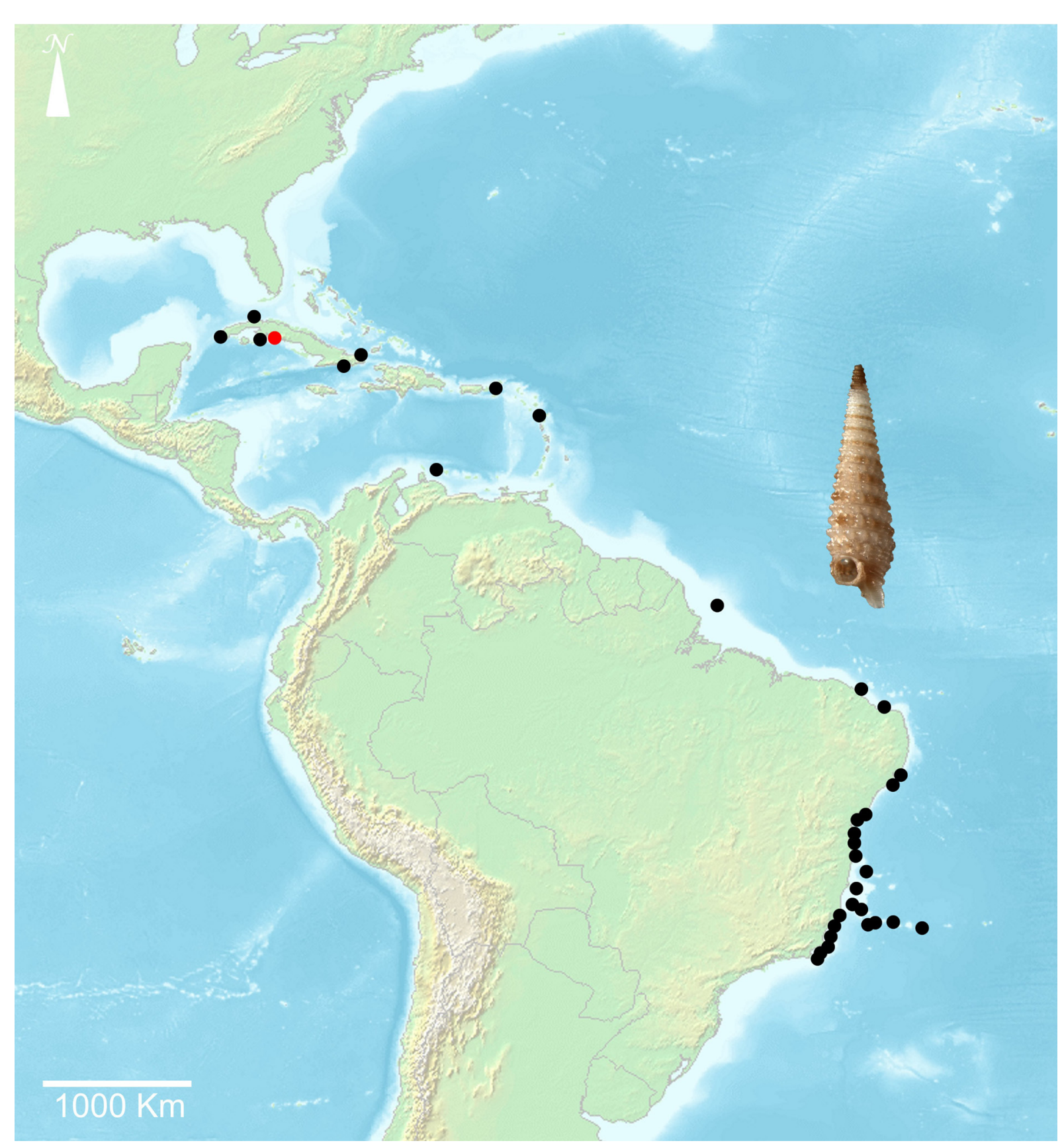

Fig. 49. Distribution map of Iniforis pseudothomae Rolán \& Fernández-Garcés, 1993; red circle = type locality. 


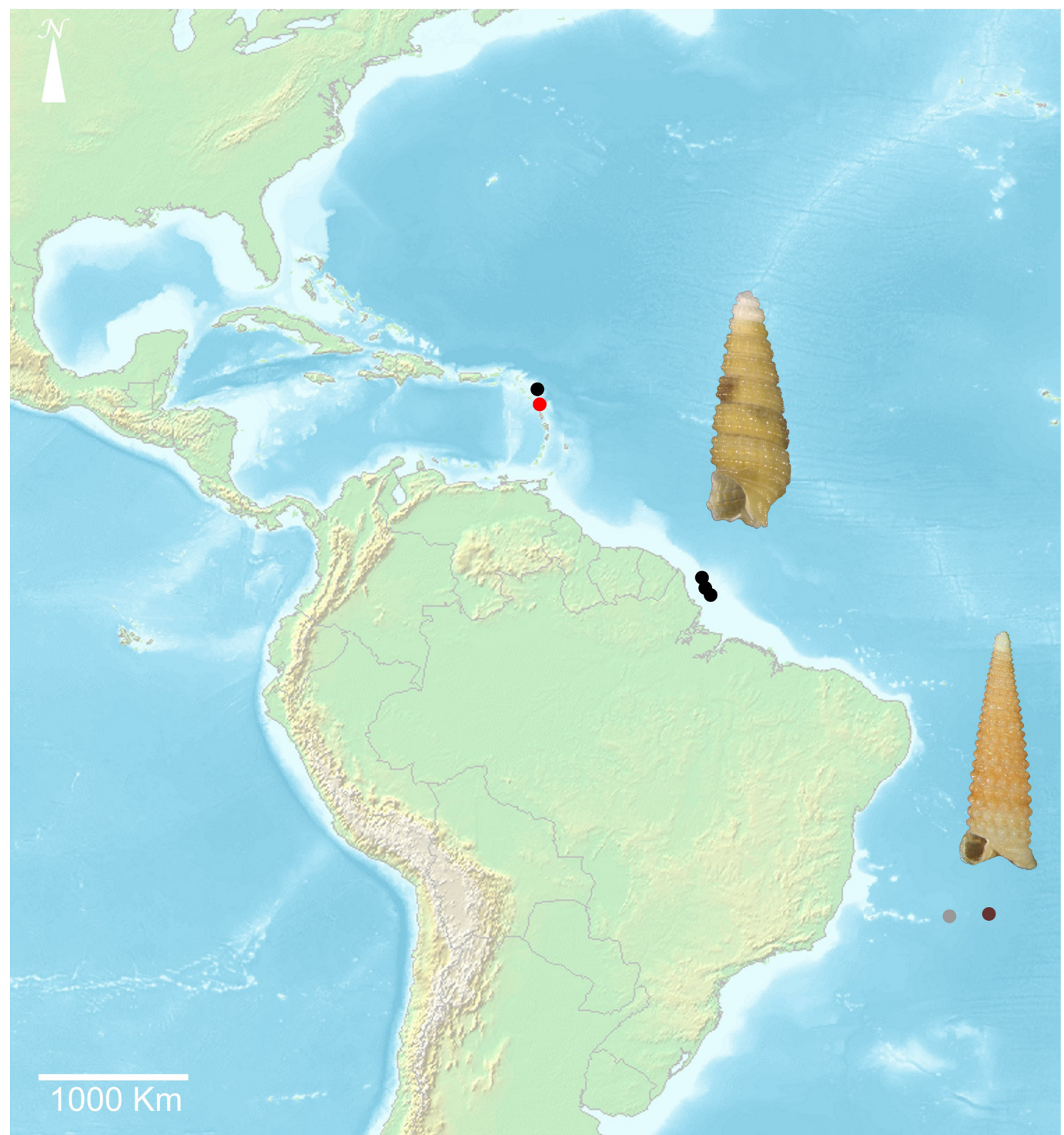

Fig. 50. Distribution map of Isotriphora tricingulata Rolán \& Fernández-Garcés, 2015 (red circle = type locality; black circles = additional localities) and Isotriphora onca Fernandes, Pimenta \& Leal, 2013 (brown circle = type locality; gray circle $=$ additional locality). 


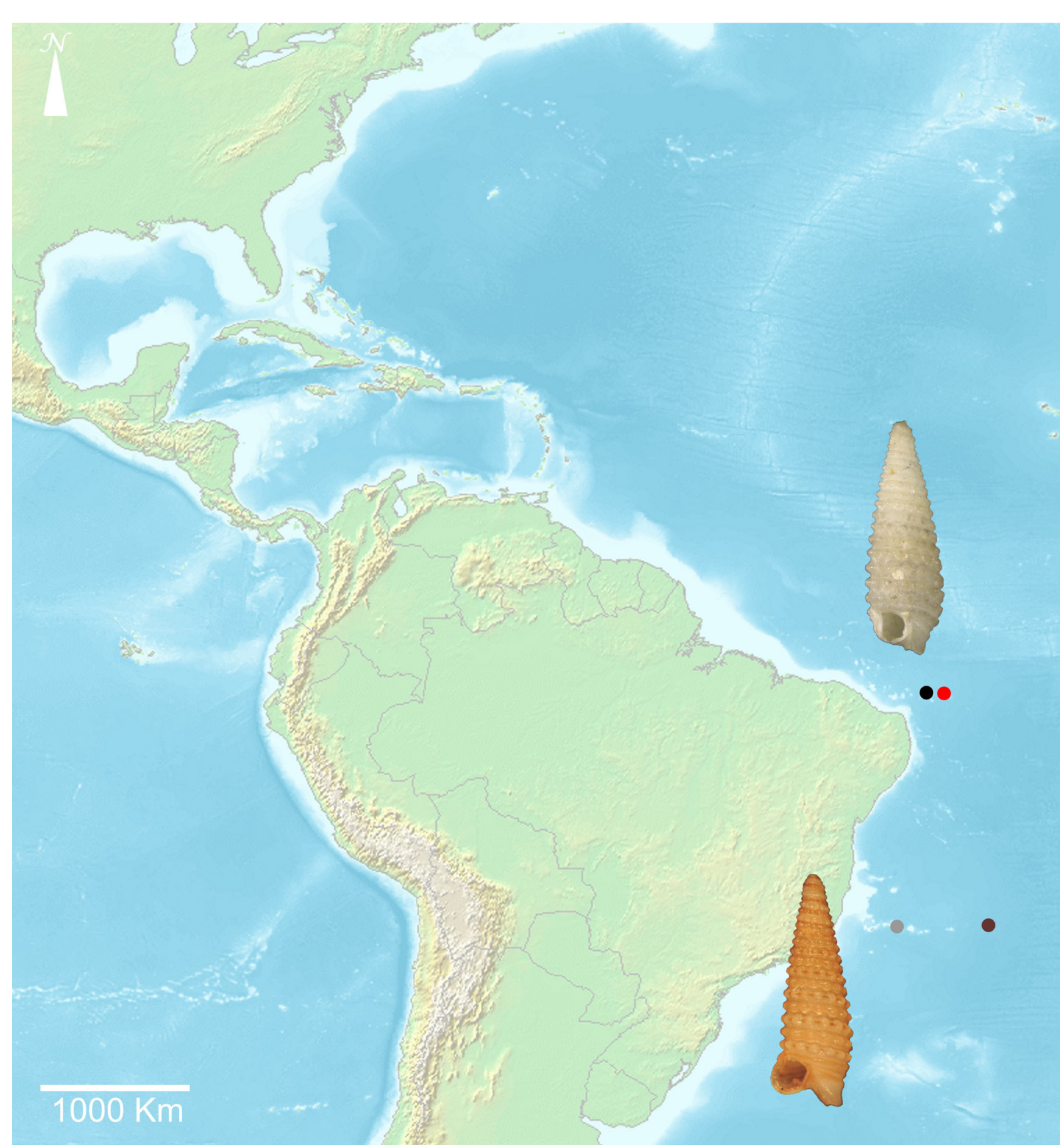

Fig. 51. Distribution map of Isotriphora uncia sp. nov. (red circle = type locality; black circle = additional locality) and Isotriphora tigrina Fernandes, Pimenta \& Leal, 2013 (brown circle = type locality; gray circle $=$ additional locality). 


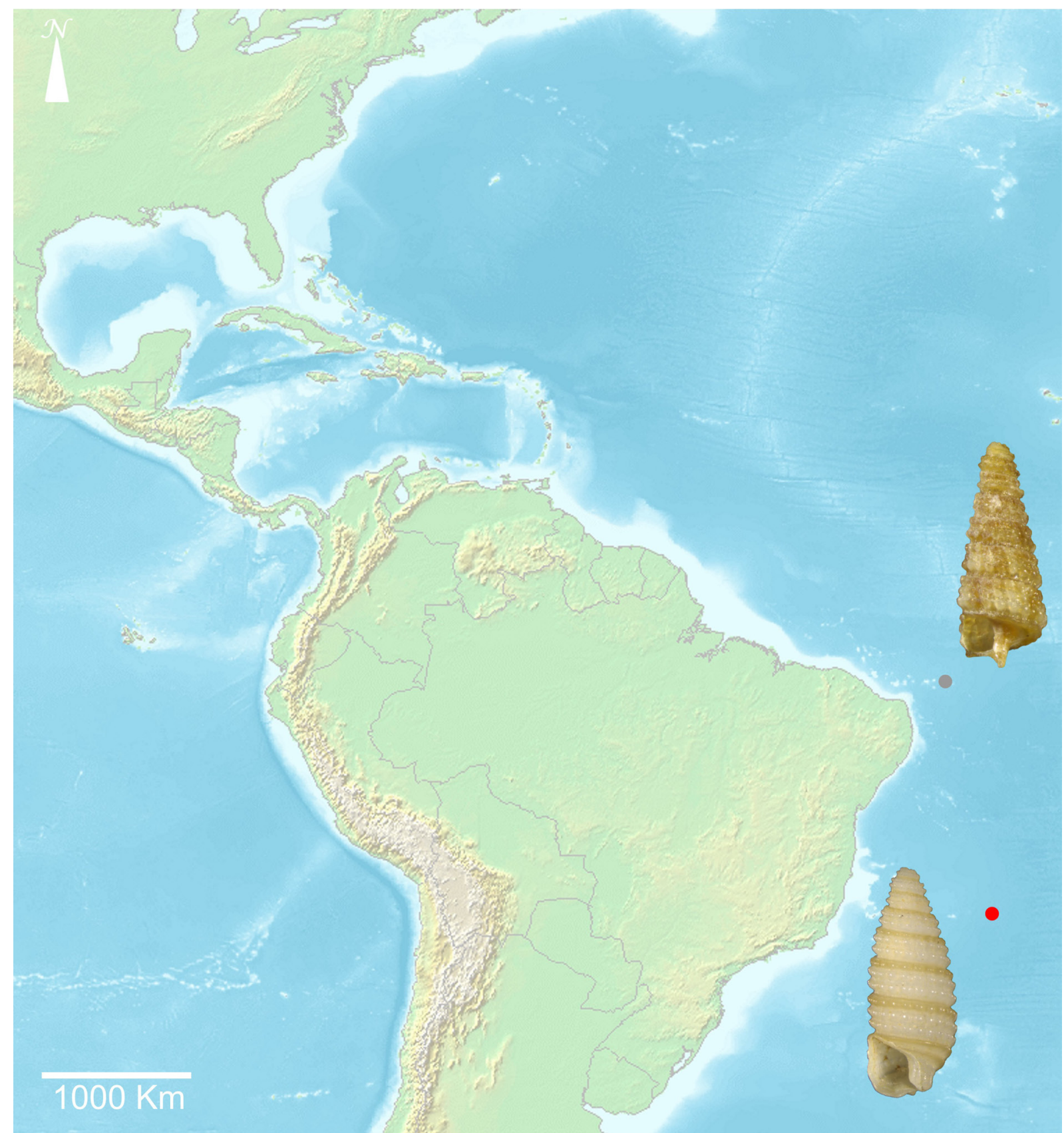

Fig. 52. Distribution map of Isotriphora sp. 1 (gray circle) and Isotriphora leo sp. nov. (red circle). 


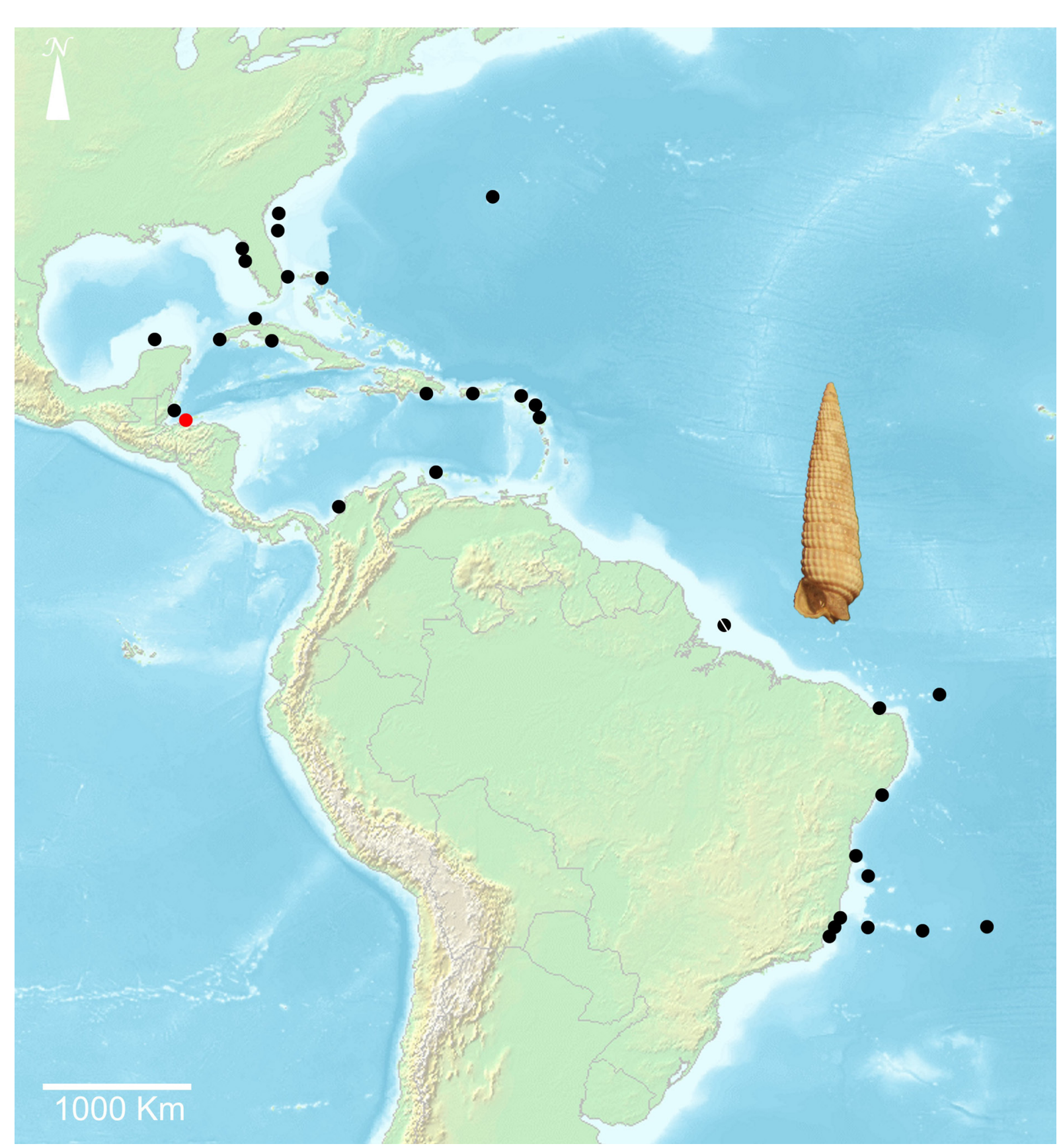

Fig. 53. Distribution map of Latitriphora albida (A. Adams, 1854); red circle = type locality. 


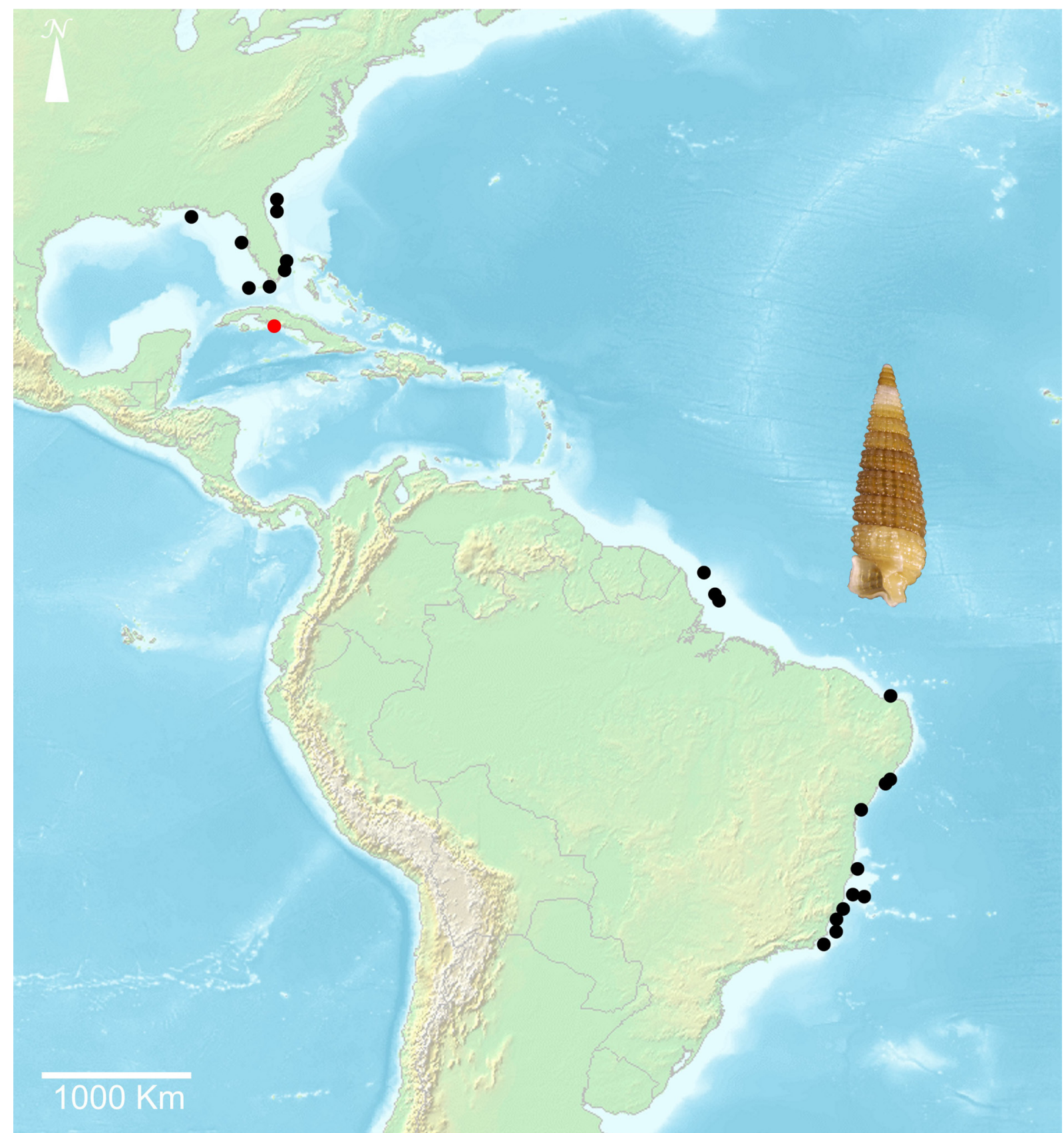

Fig. 54. Distribution map of Marshallora ostenta Rolán \& Fernández-Garcés, 2008; red circle = type locality. 


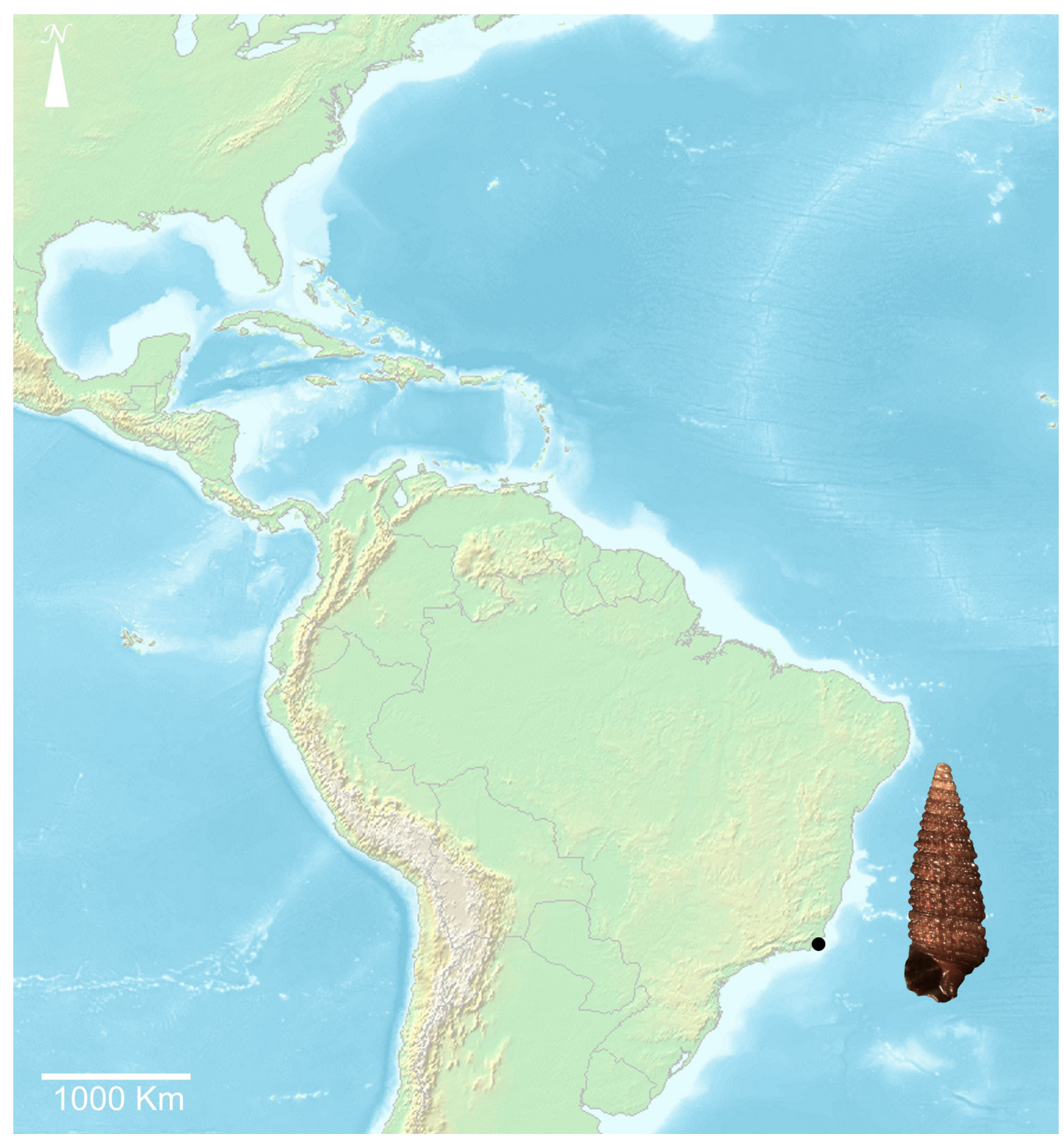

Fig. 55. Distribution map of Marshallora sp. 1. 


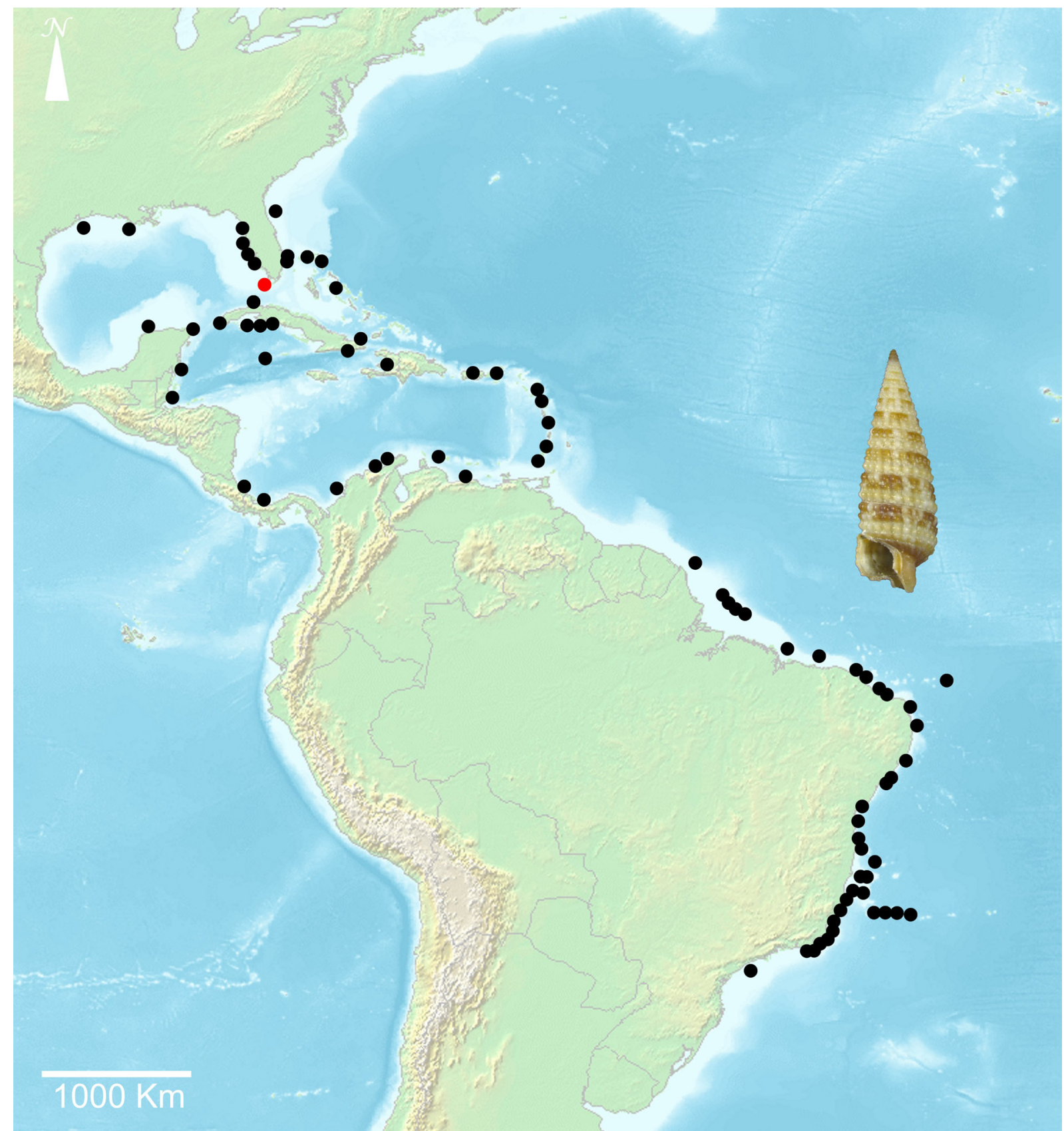

Fig. 56. Distribution map of Monophorus olivaceus (Dall, 1889); red circle = type locality. 


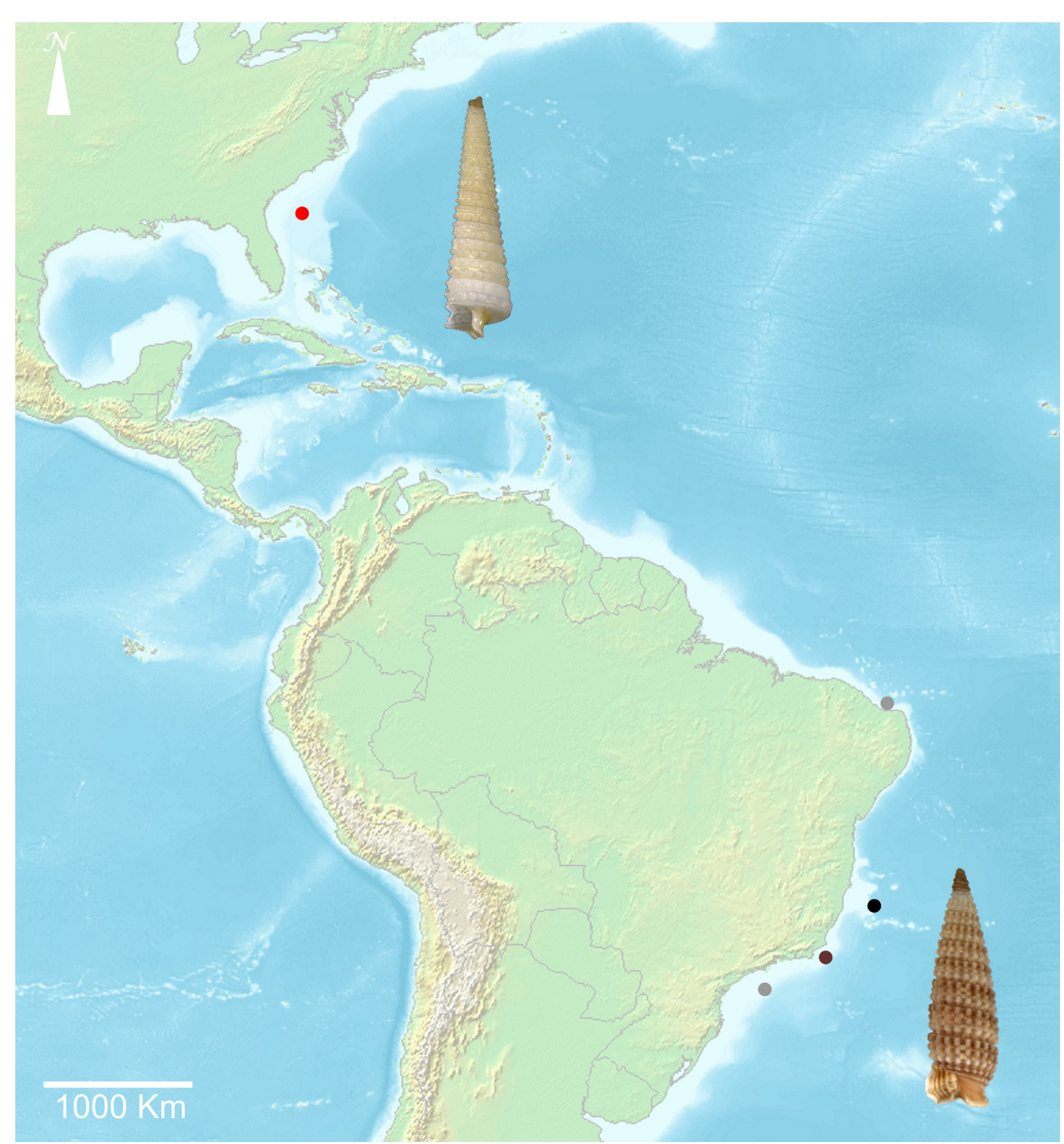

Fig. 57. Distribution map of Monophorus caracca (Dall, 1927) comb. nov. (red circle = type locality; black circle = additional locality) and Monophorus verecundus sp. nov. (brown circle = type locality; gray circles $=$ additional localities). 


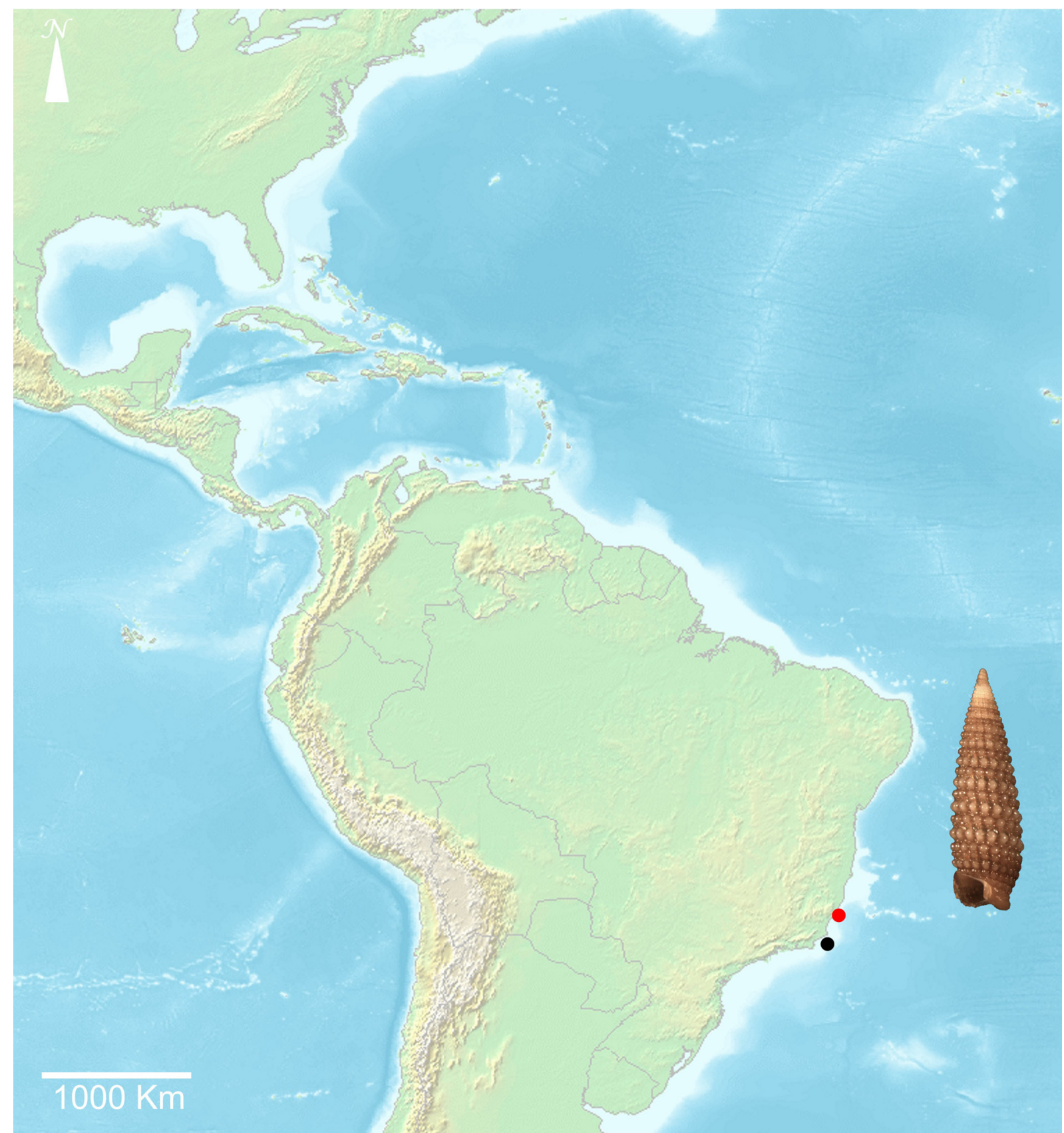

Fig. 58. Distribution map of Nanaphora leei Fernandes \& Pimenta, 2015; red circle = type locality. 


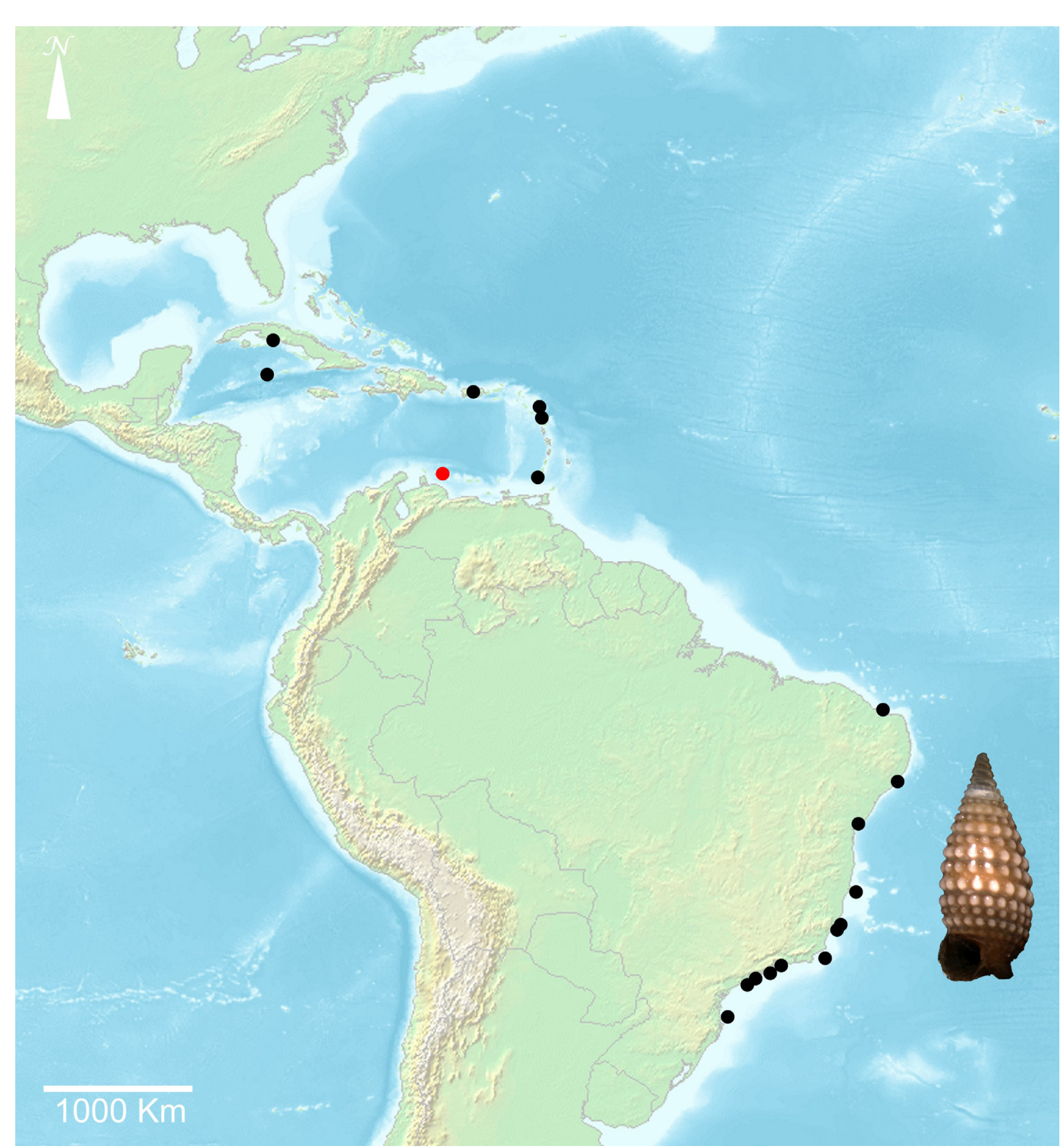

Fig. 59. Distribution map of Nanaphora verbernei (Moolenbeek \& Faber, 1989); red circle = type locality. 


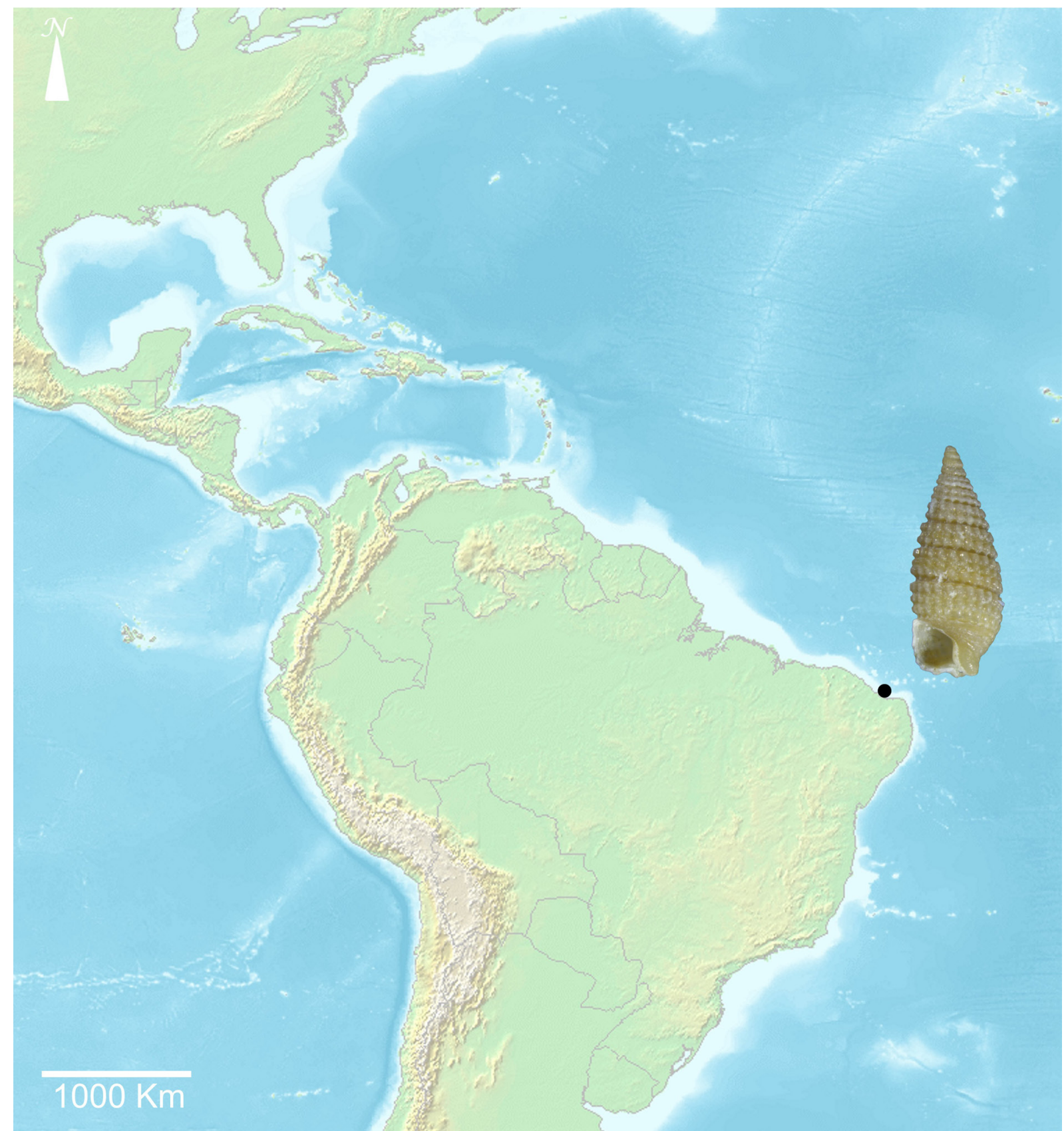

Fig. 60. Distribution map of Nanaphora sp. 1. 


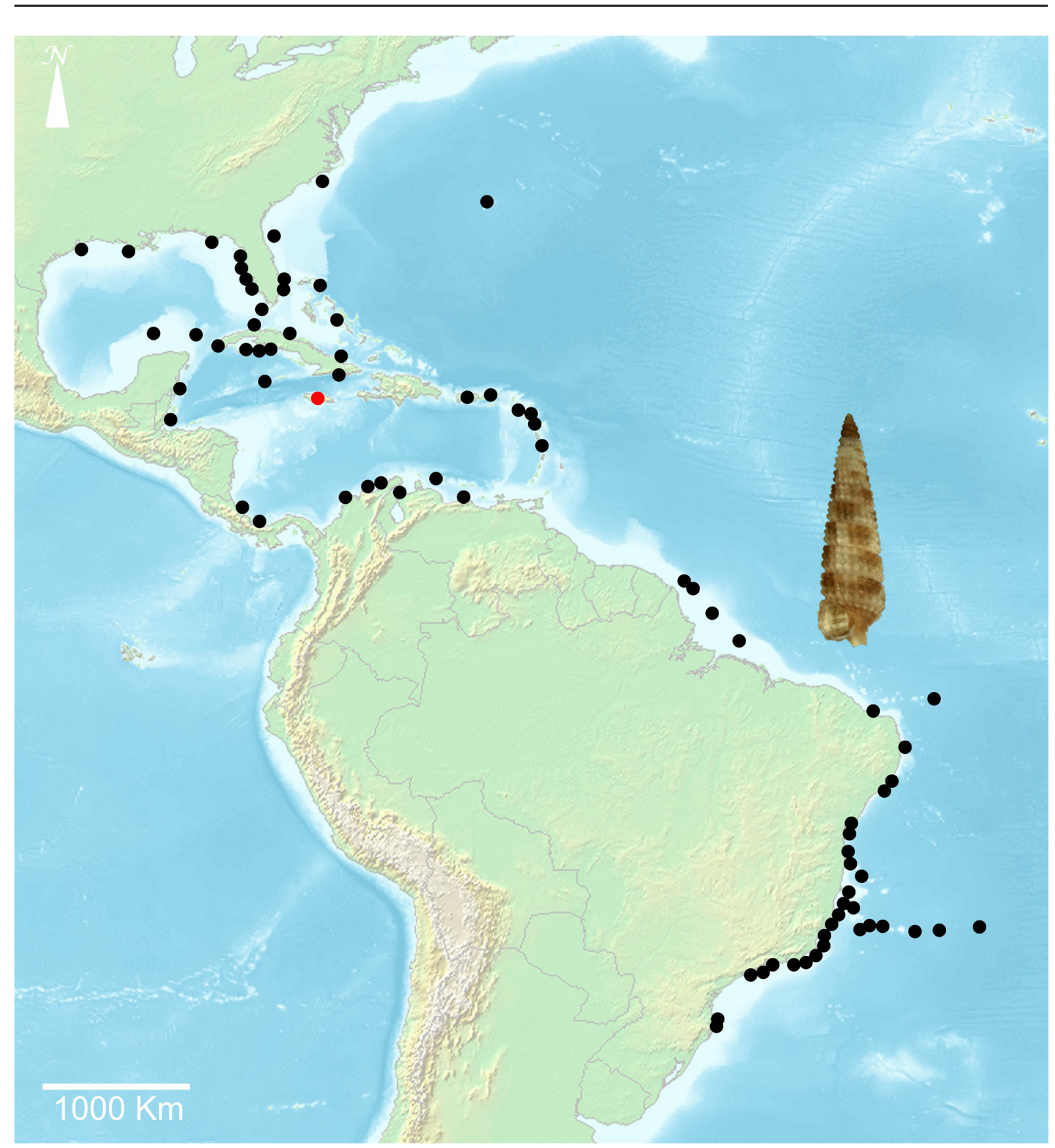

Fig. 61. Distribution map of Nototriphora decorata (C.B. Adams, 1850); red circle = type locality. 


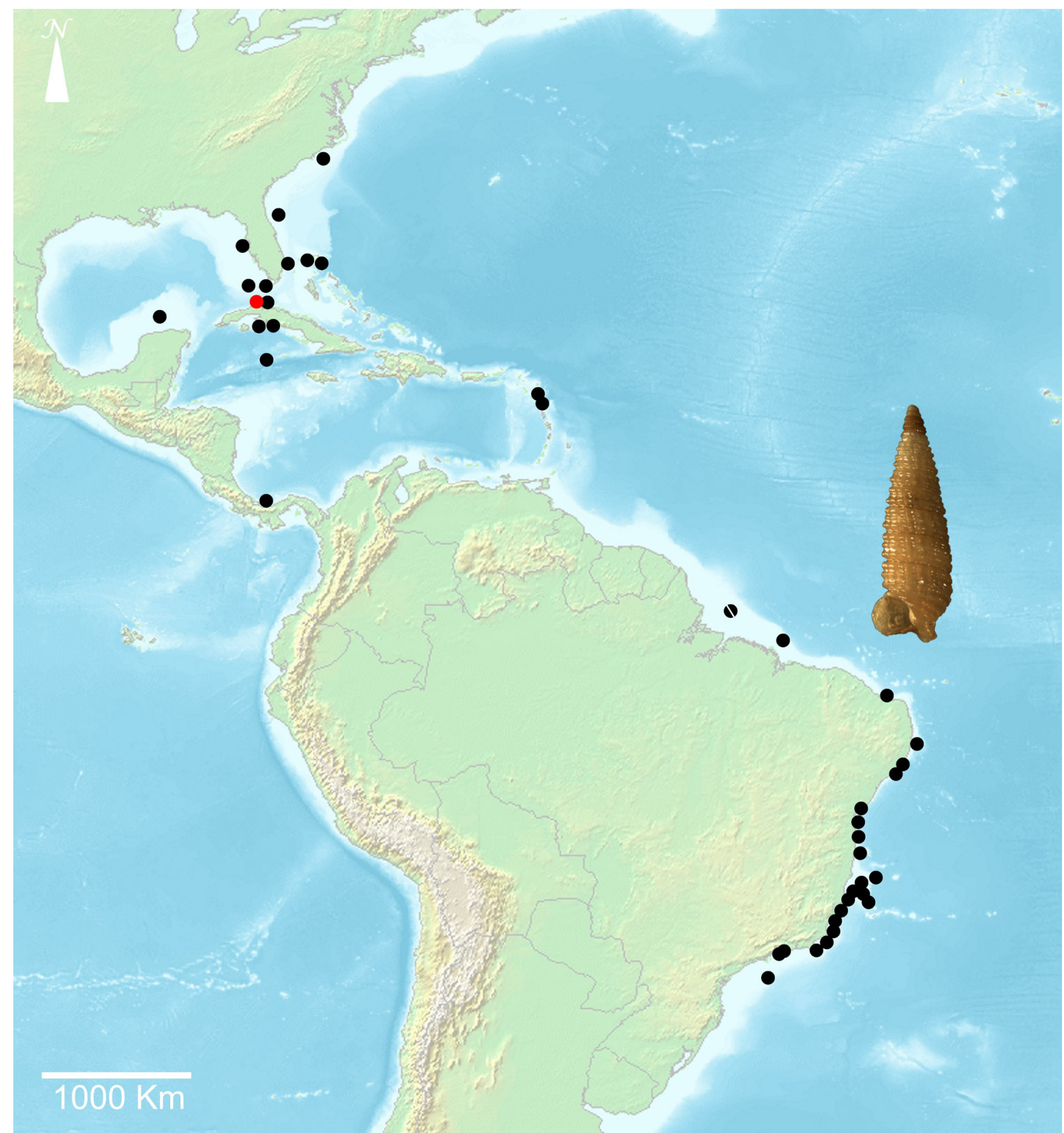

Fig. 62. Distribution map of Sagenotriphora osclausum (Rolán \& Fernández-Garcés, 1995); red circle = type locality. 


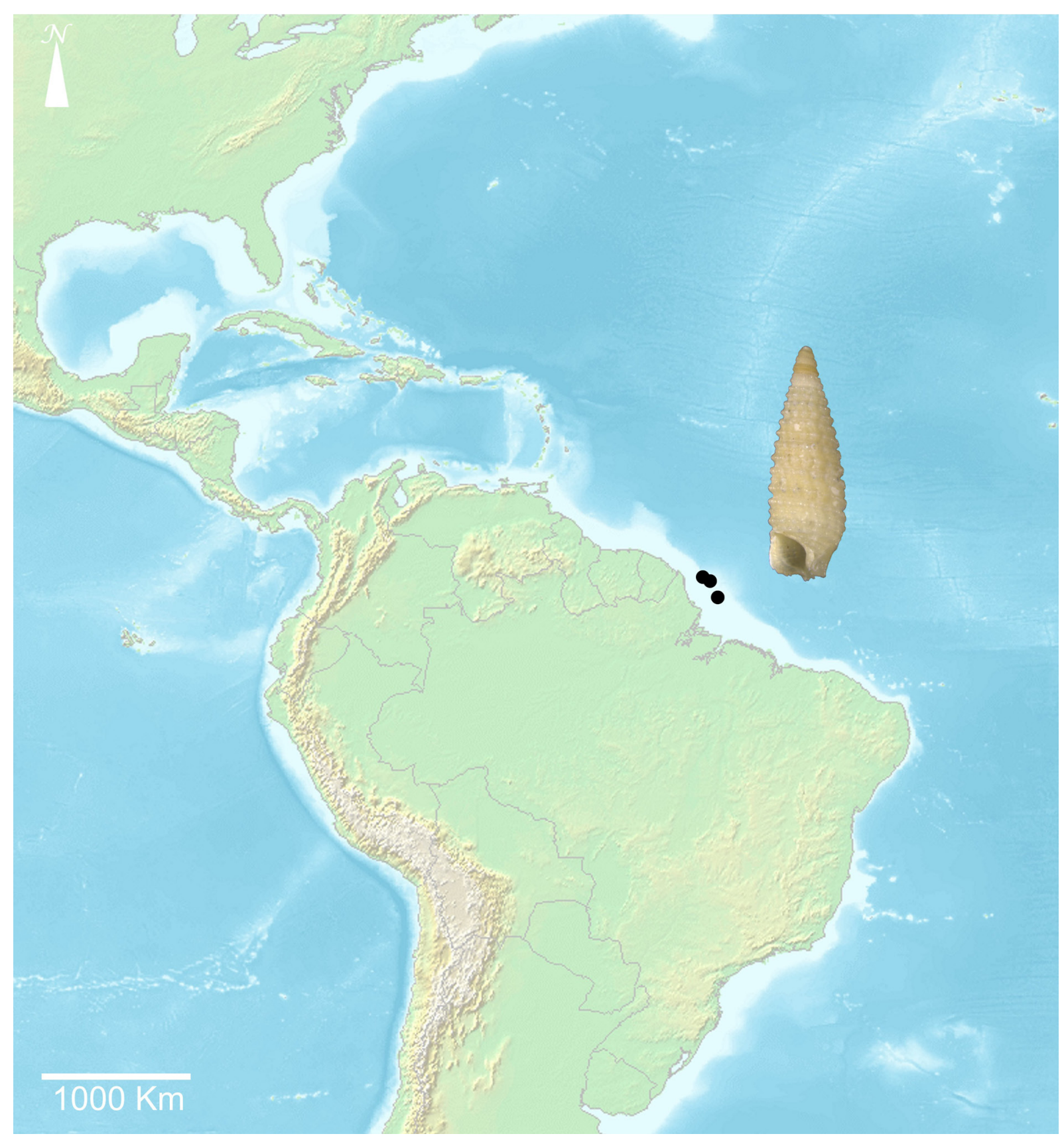

Fig. 63. Distribution map of Sagenotriphora sp. 1. 


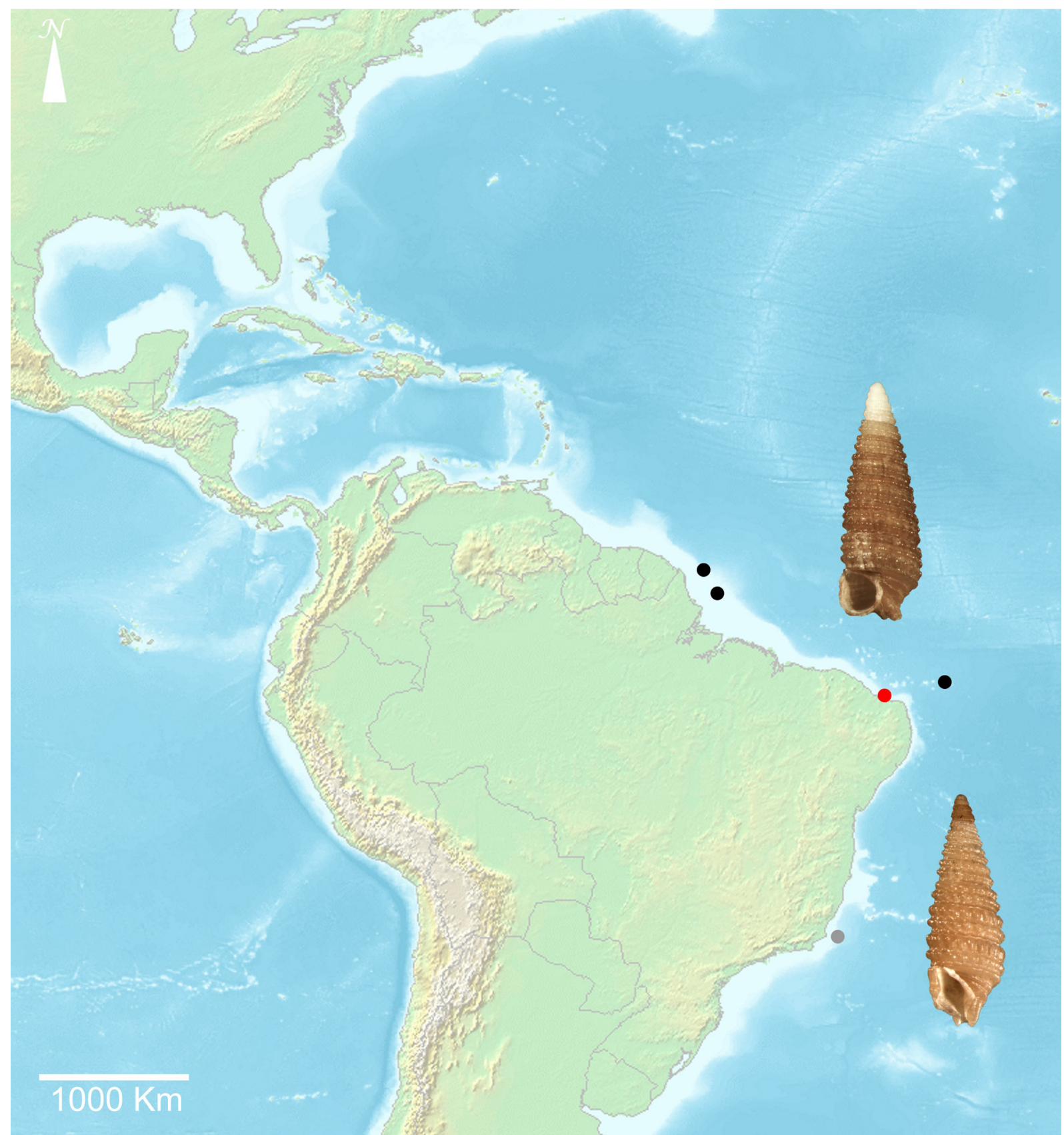

Fig. 64. Distribution map of Sagenotriphora albocaput sp. nov. (red circle = type locality; black circles = additional localities) and Sagenotriphora sp. 2 (gray circle). 


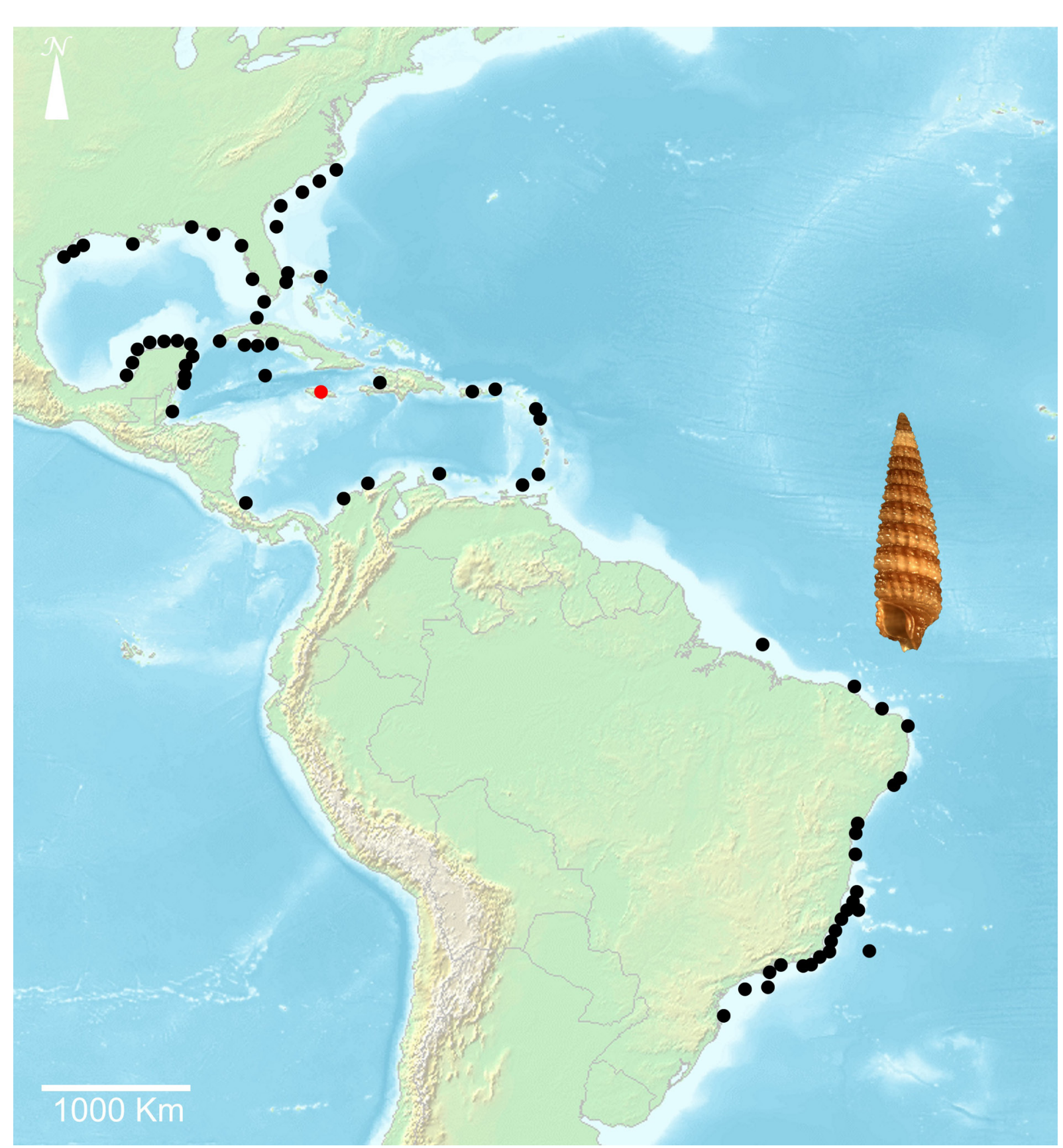

Fig. 65. Distribution map of Similiphora intermedia (C.B. Adams, 1850); red circle = type locality. 


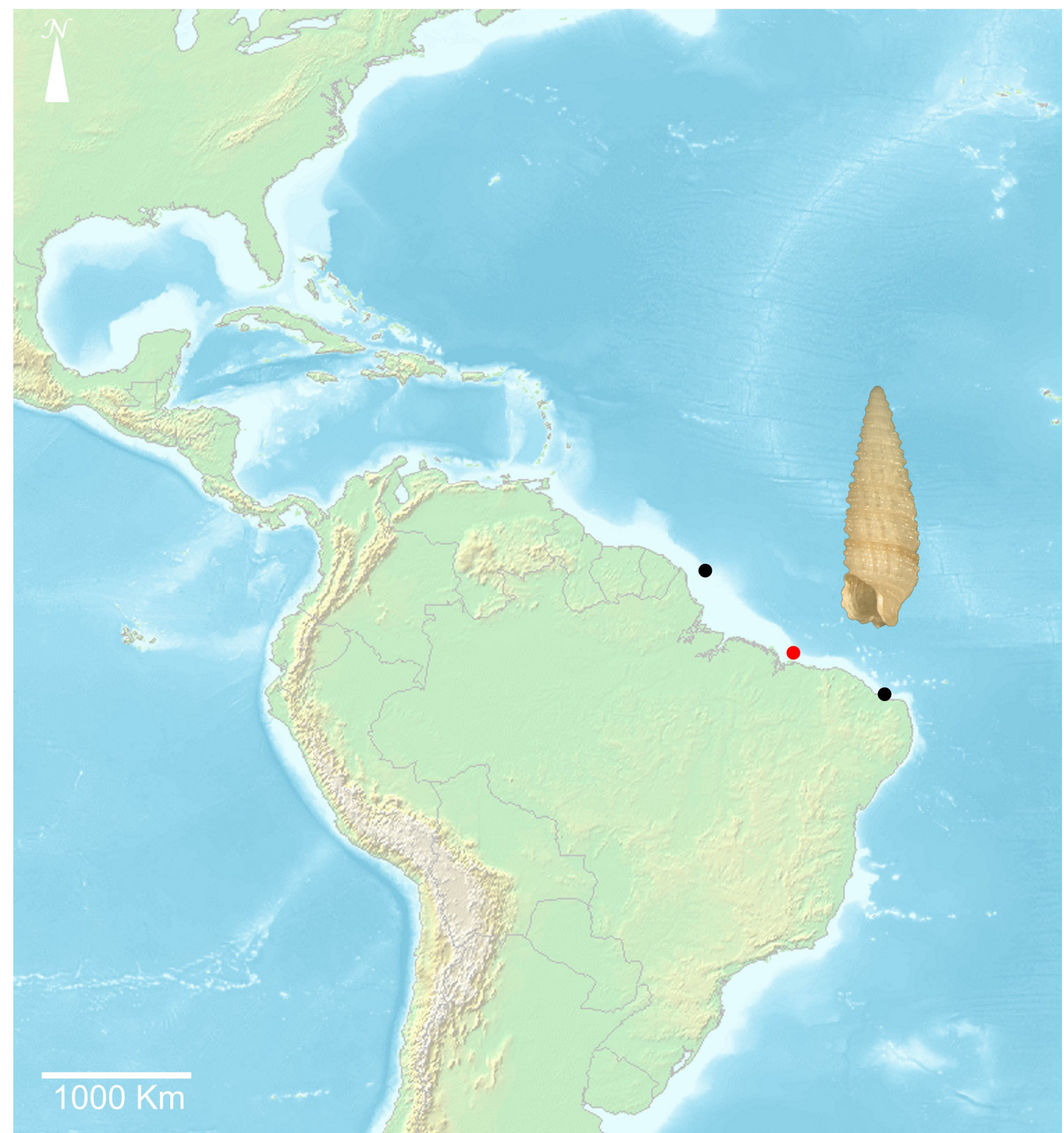

Fig. 66. Distribution map of Similiphora lucida sp. nov.; red circle = type locality. 


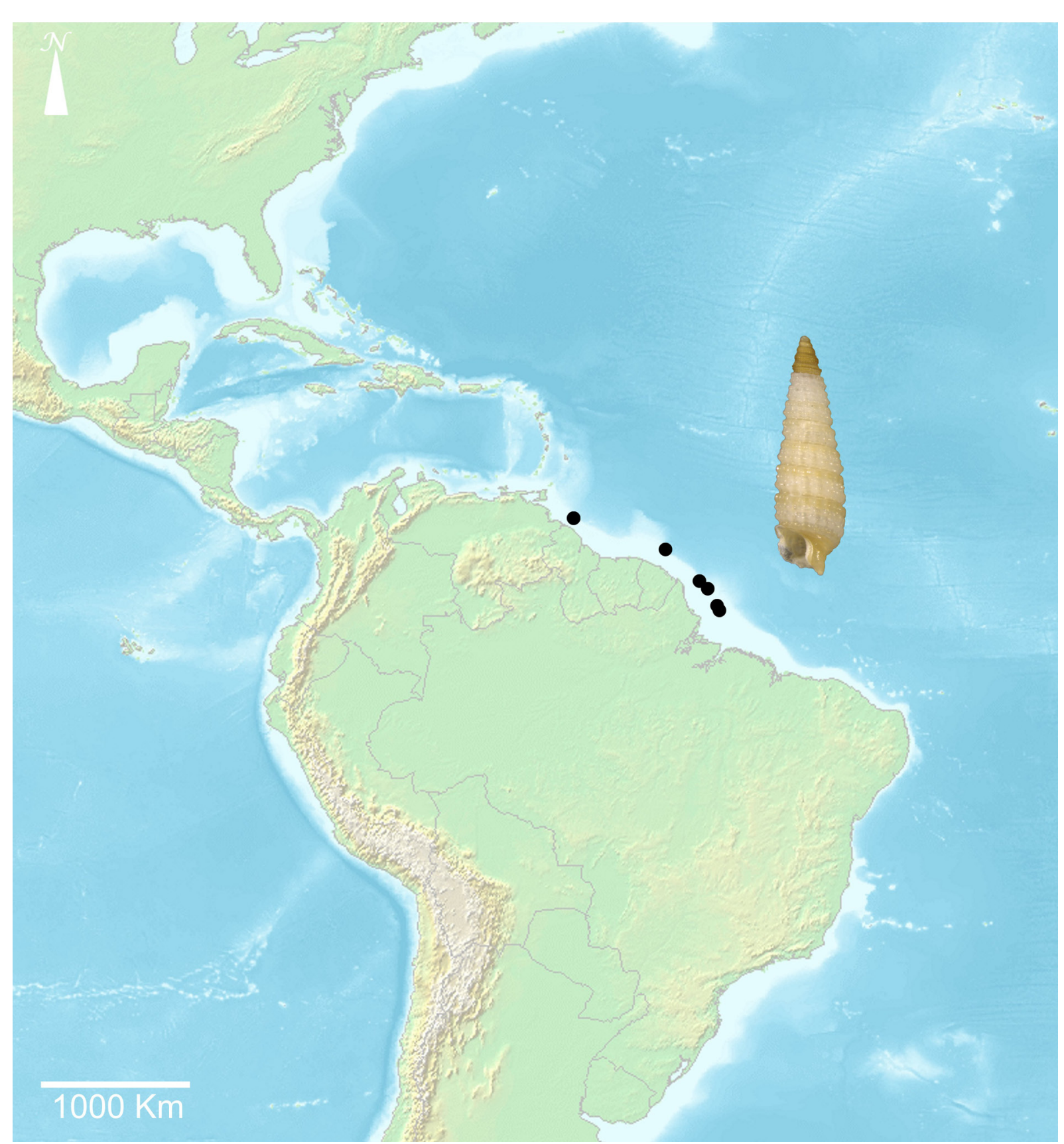

Fig. 67. Distribution map of Similiphora sp. 1. 


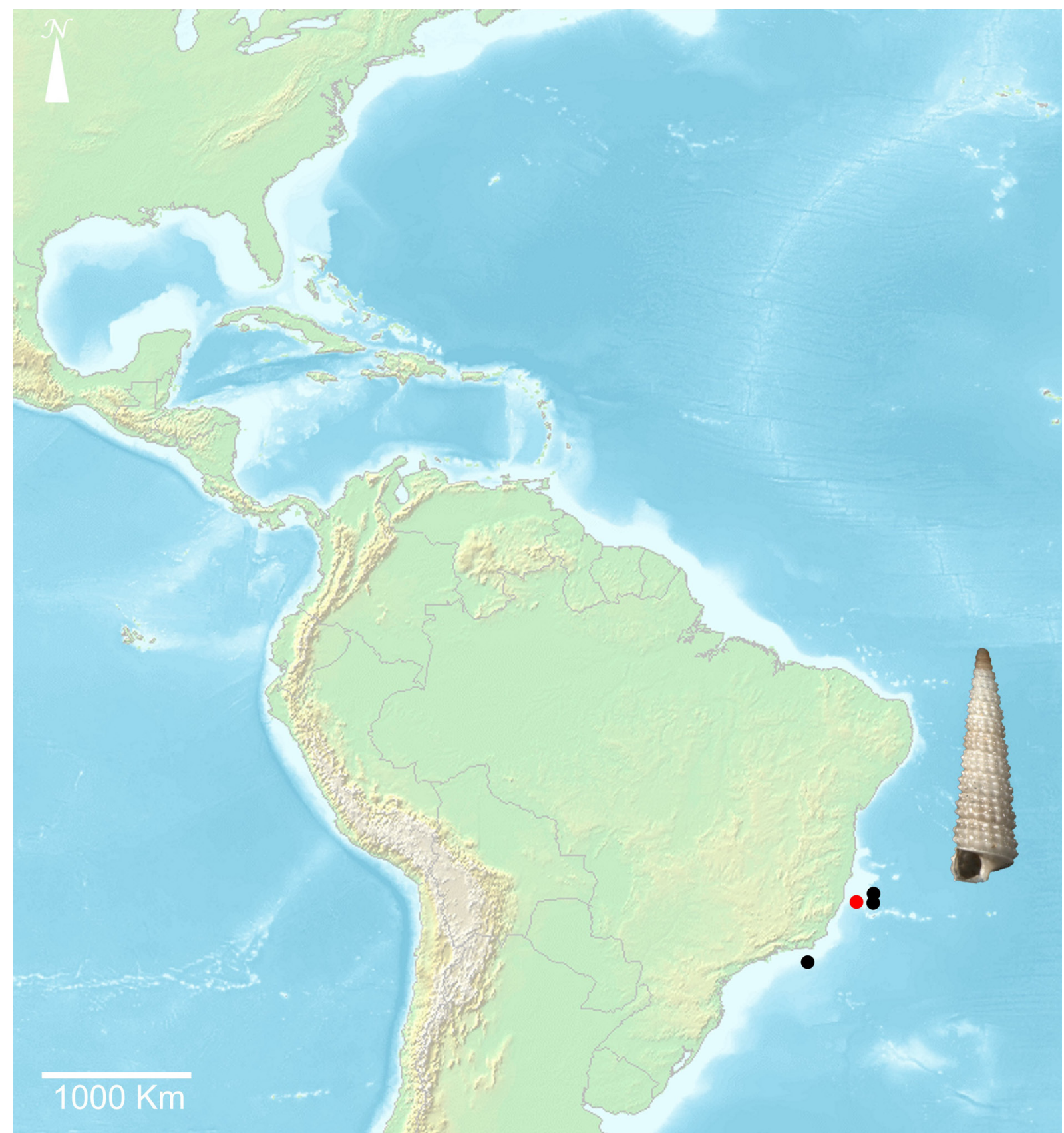

Fig. 68. Distribution map of Strobiligera delicata Fernandes \& Pimenta, 2014; red circle = type locality. 


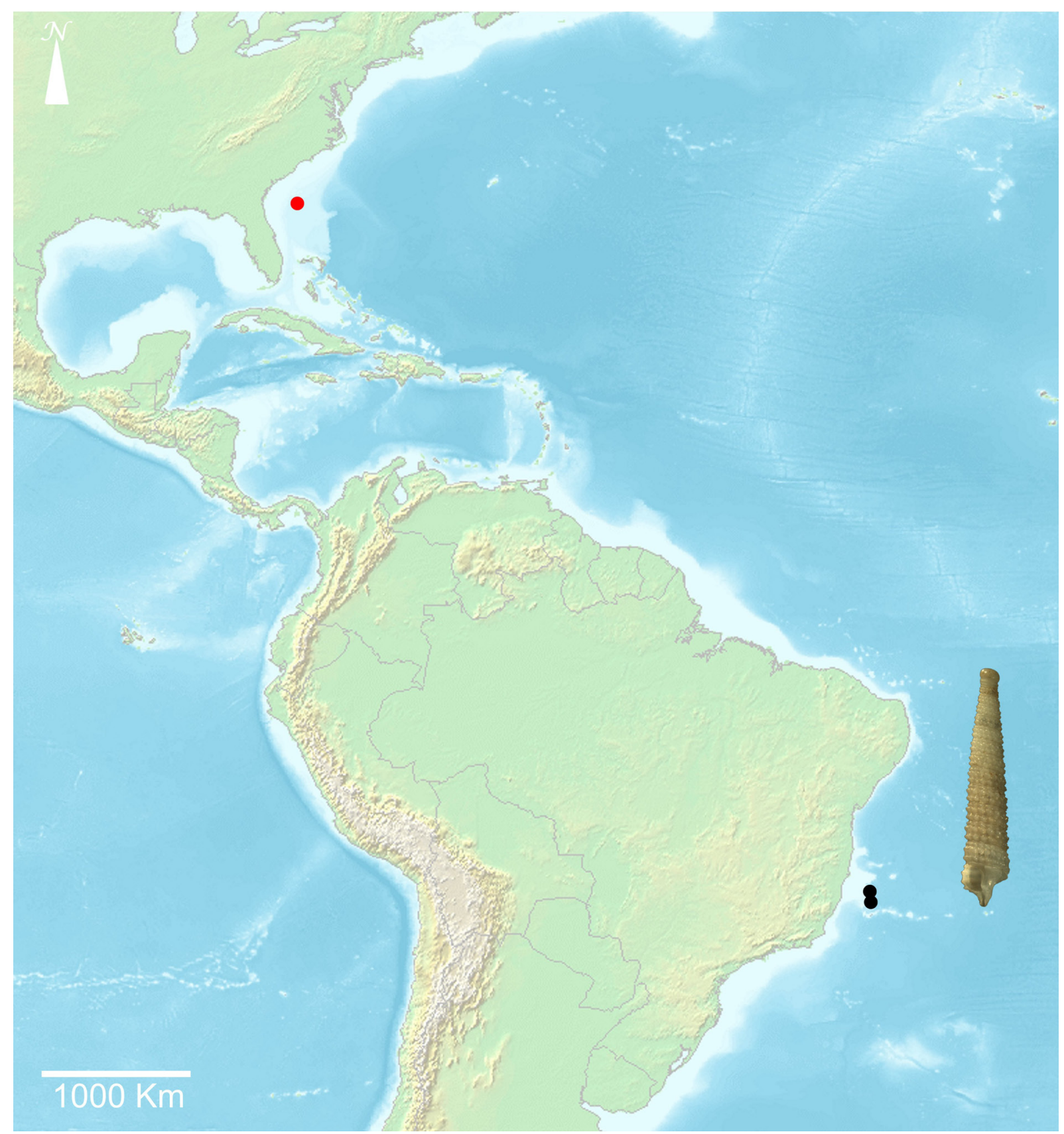

Fig. 69. Distribution map of Strobiligera dinea (Dall, 1927); red circle = type locality. 


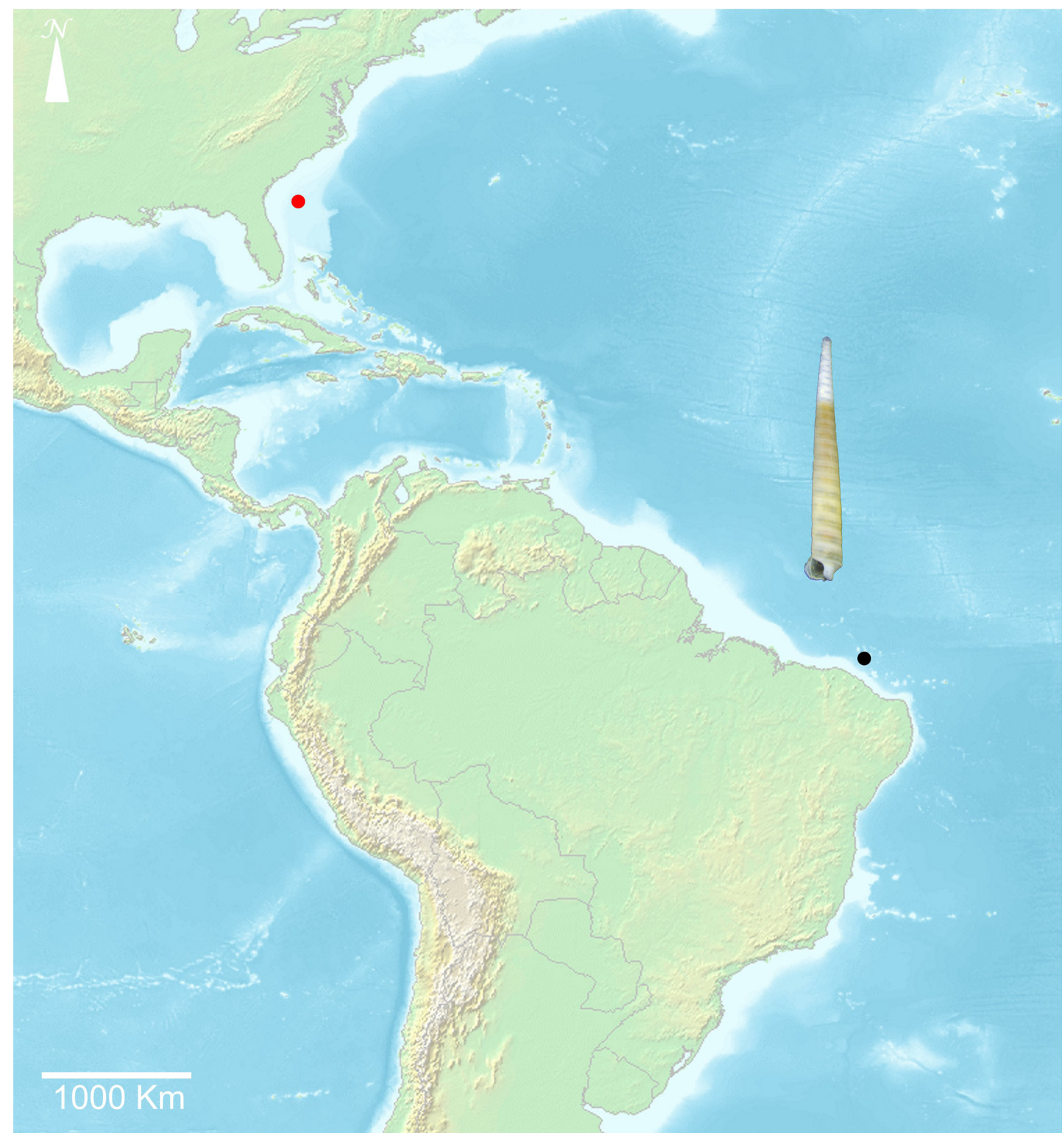

Fig. 70. Distribution map of Strobiligera gaesona (Dall, 1927); red circle = type locality 


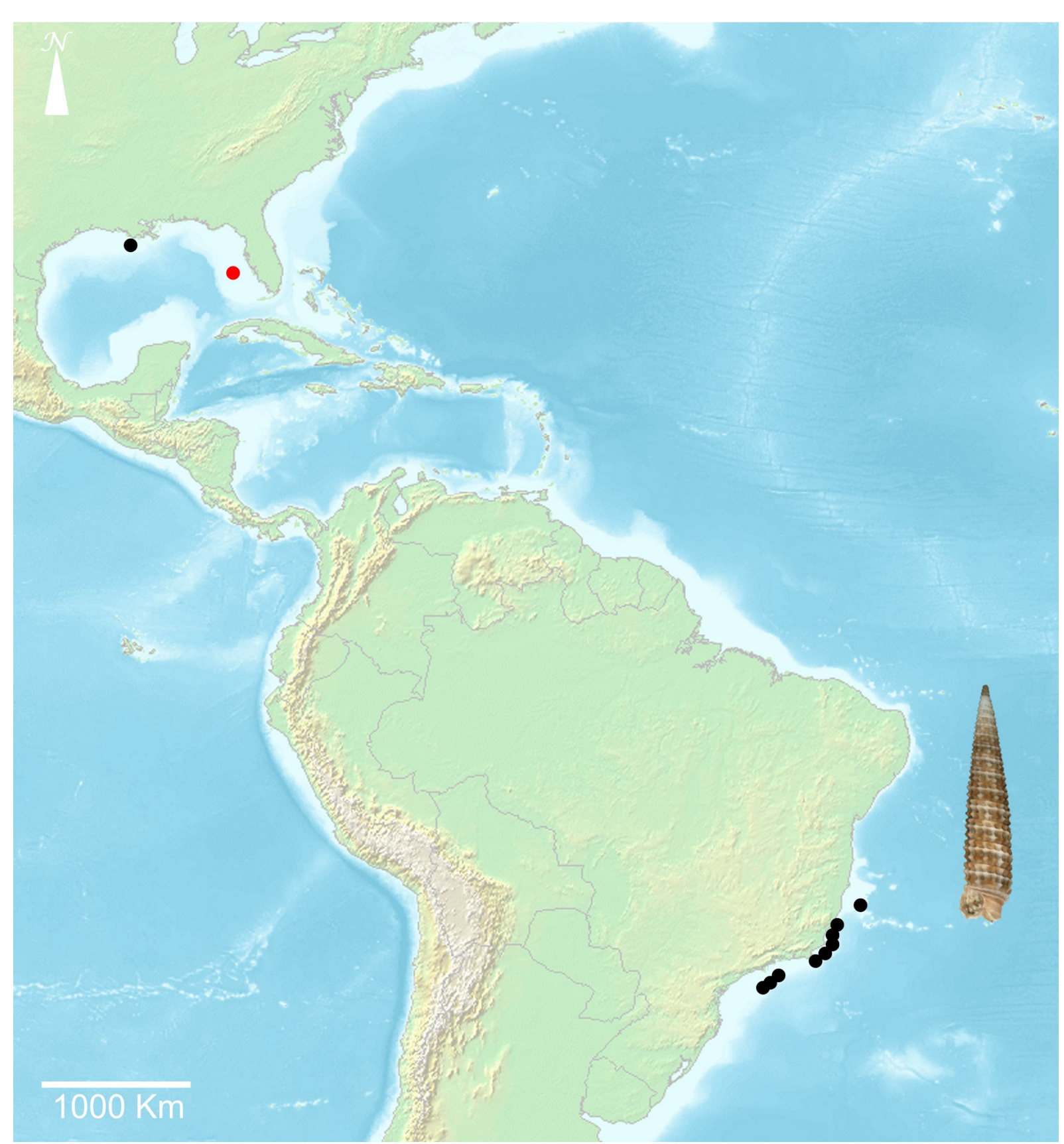

Fig. 71. Distribution map of Strobiligera inaudita (Rolán \& Lee, 2008); red circle = type locality. 


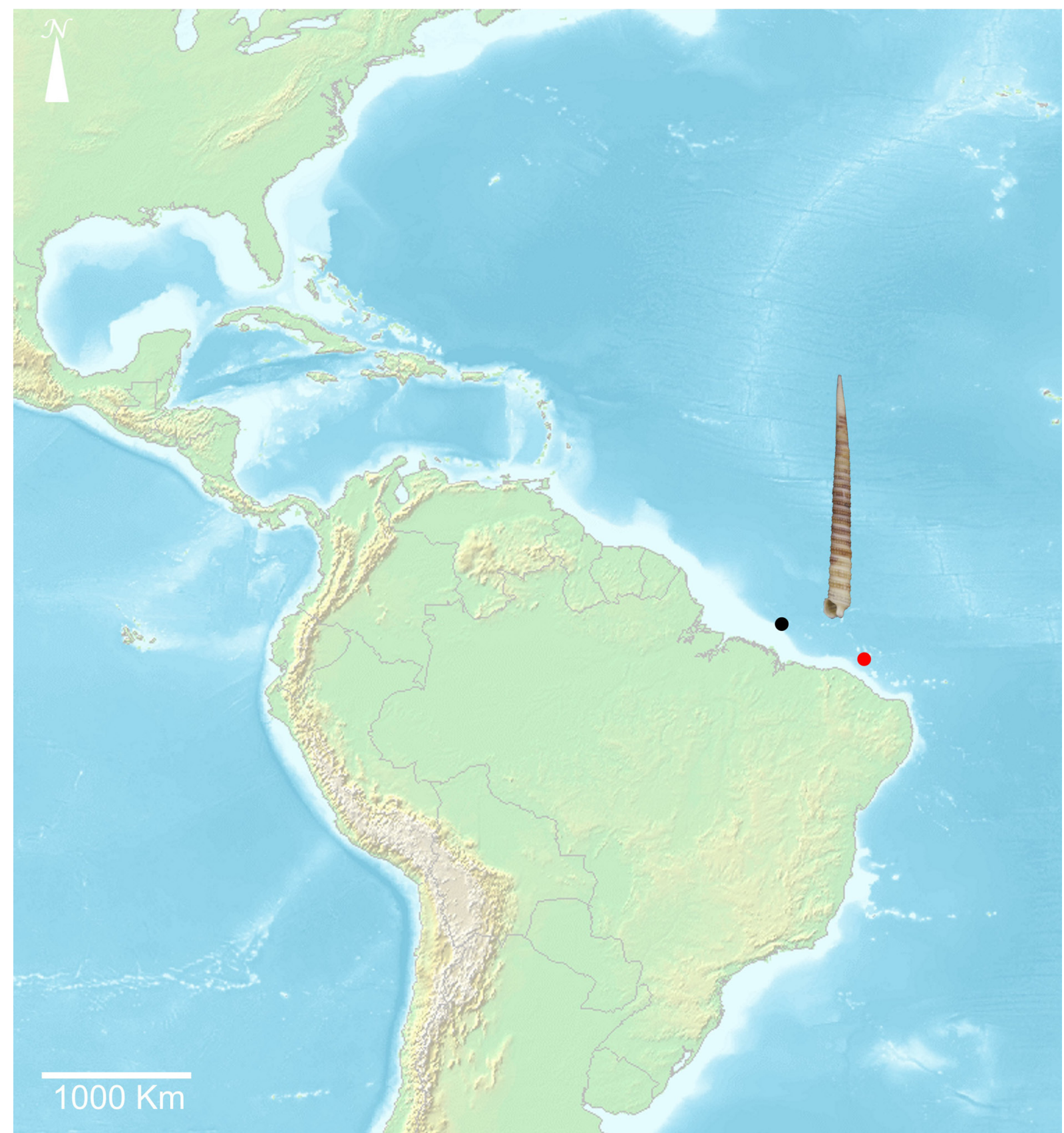

Fig. 72. Distribution map of Strobiligera unicornium (Simone, 2006); red circle = type locality. 


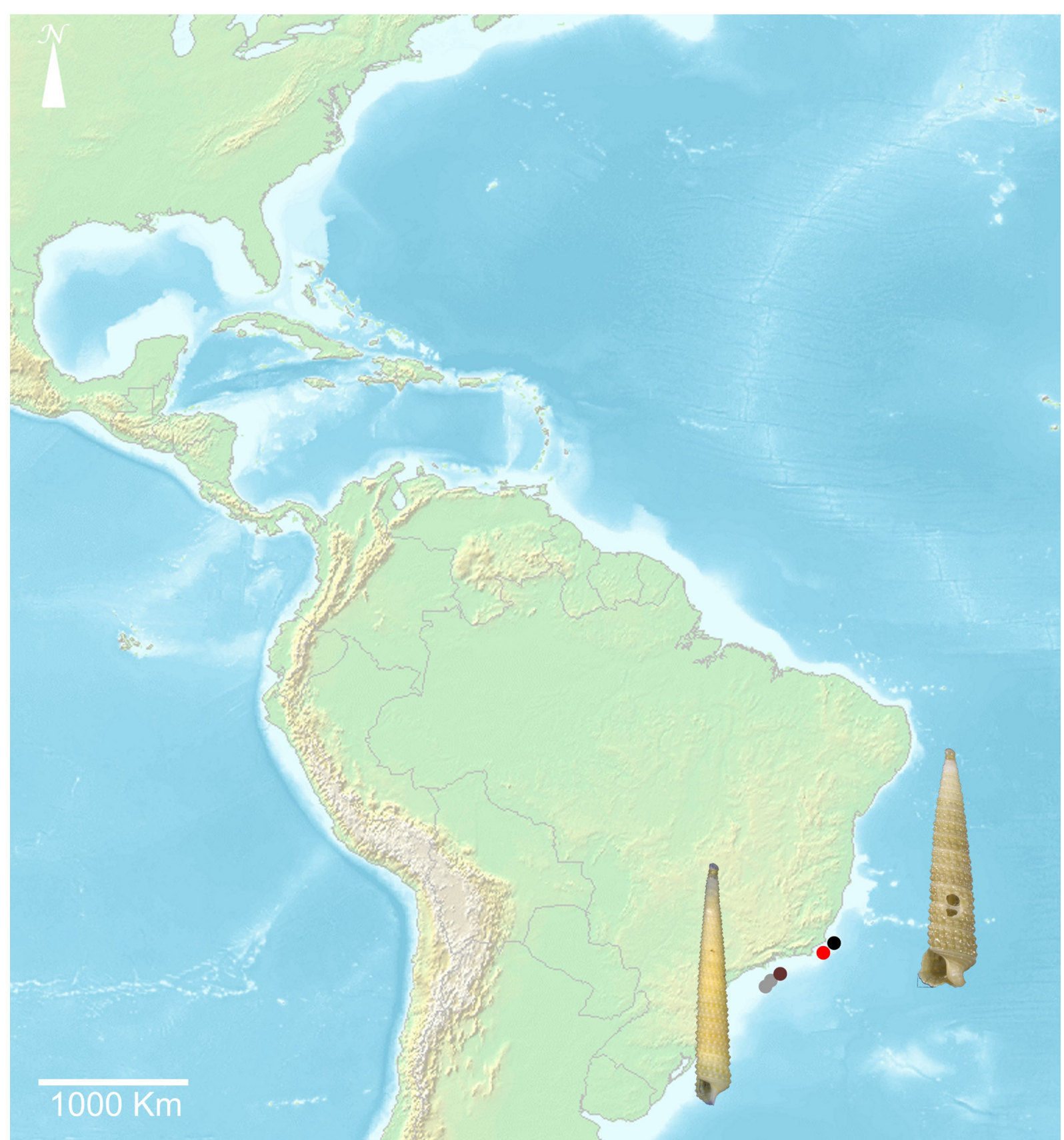

Fig. 73. Distribution map of Strobiligera campista Fernandes \& Pimenta, 2019 (red circle = type locality; black circle $=$ additional locality) and Strobiligera santista Fernandes \& Pimenta, 2019 (brown circle = type locality; gray circles = additional localities). 


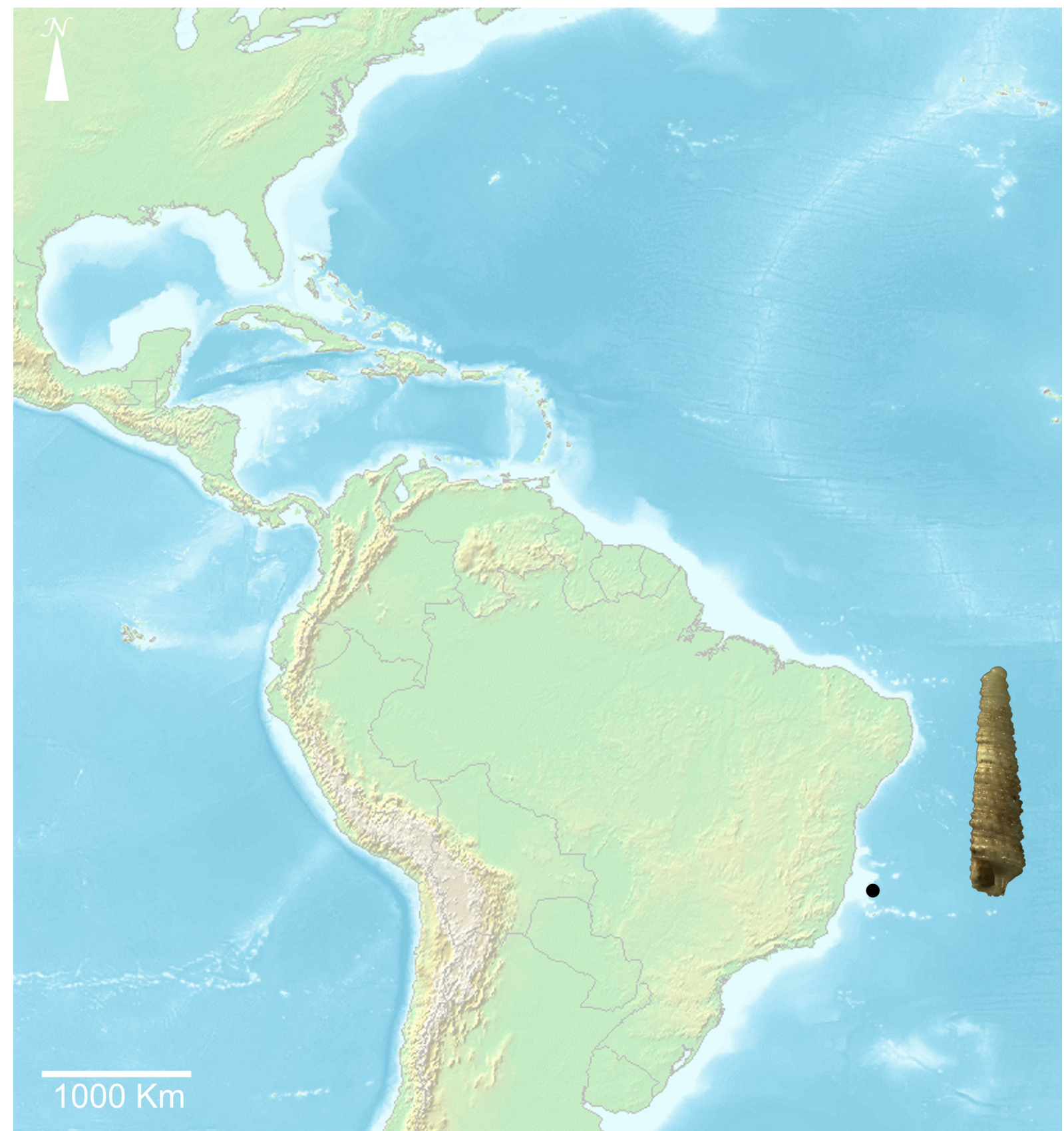

Fig. 74. Distribution map of Strobiligera sp. 1. 


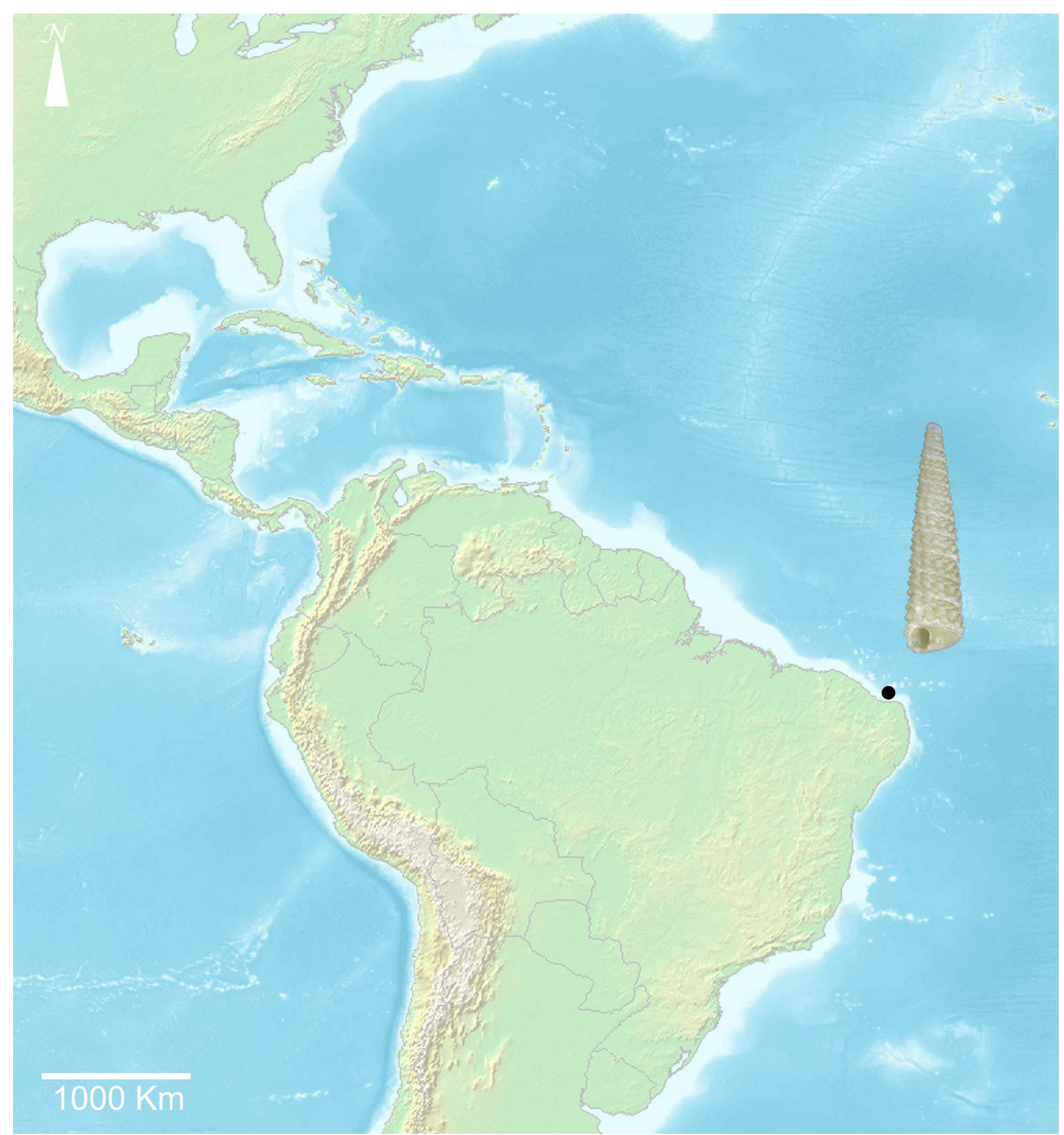

Fig. 75. Distribution map of Strobiligera sp. 2. 


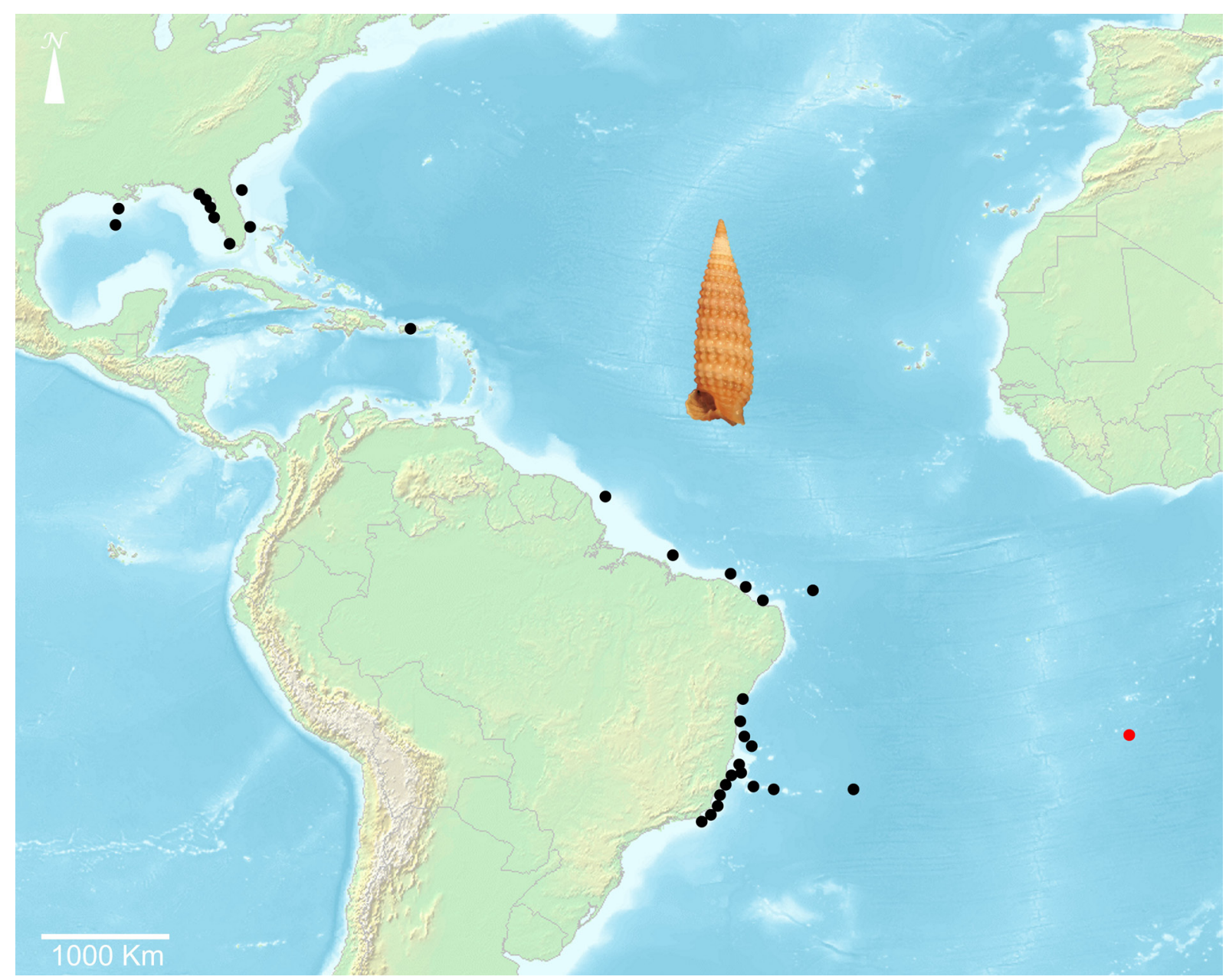

Fig. 76. Distribution map of Triphora atlantica Smith, 1890; red circle = type locality. 


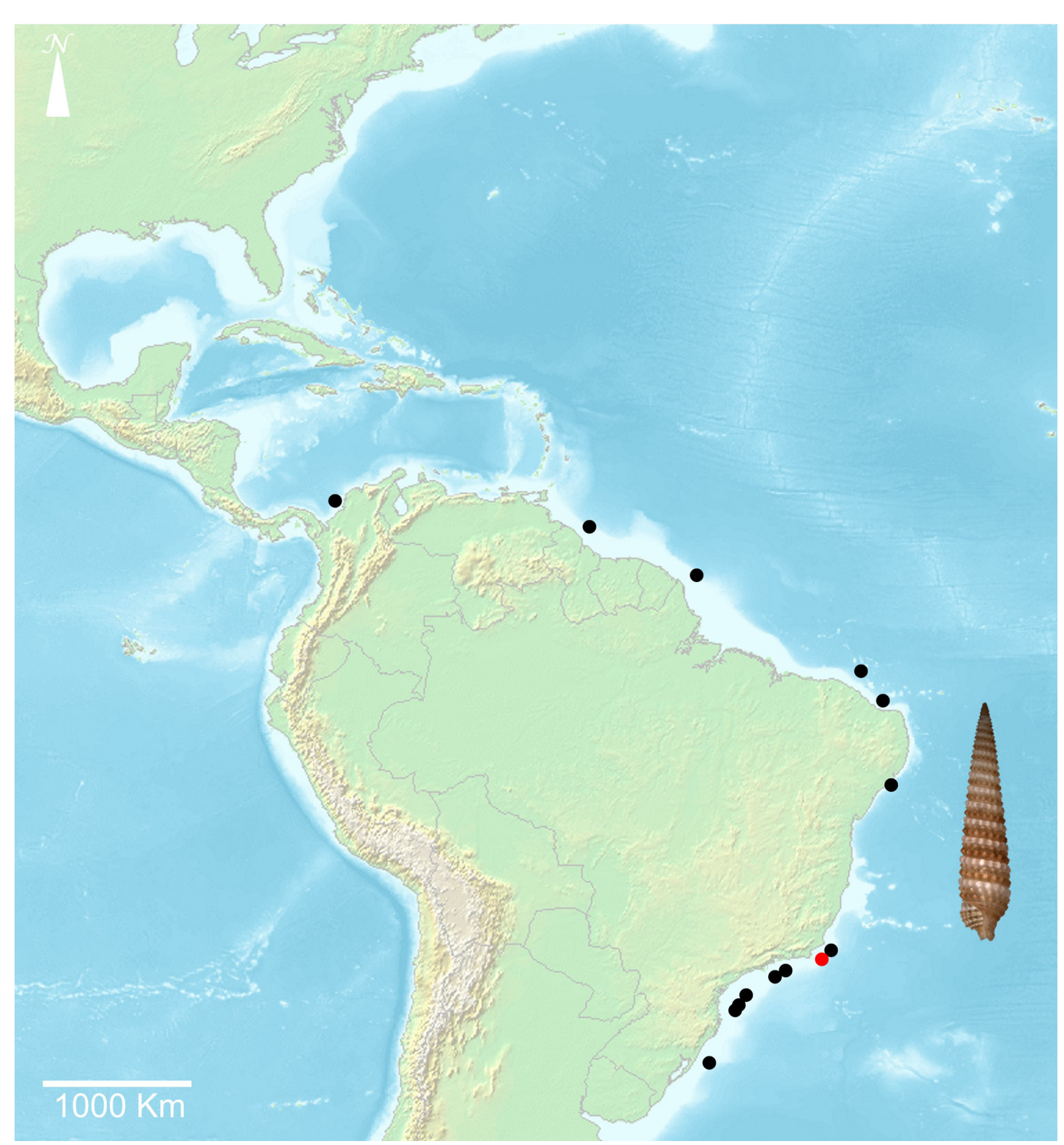

Fig. 77. Distribution map of Triphora charybdis Fernandes \& Pimenta, 2015; red circle = type locality. 


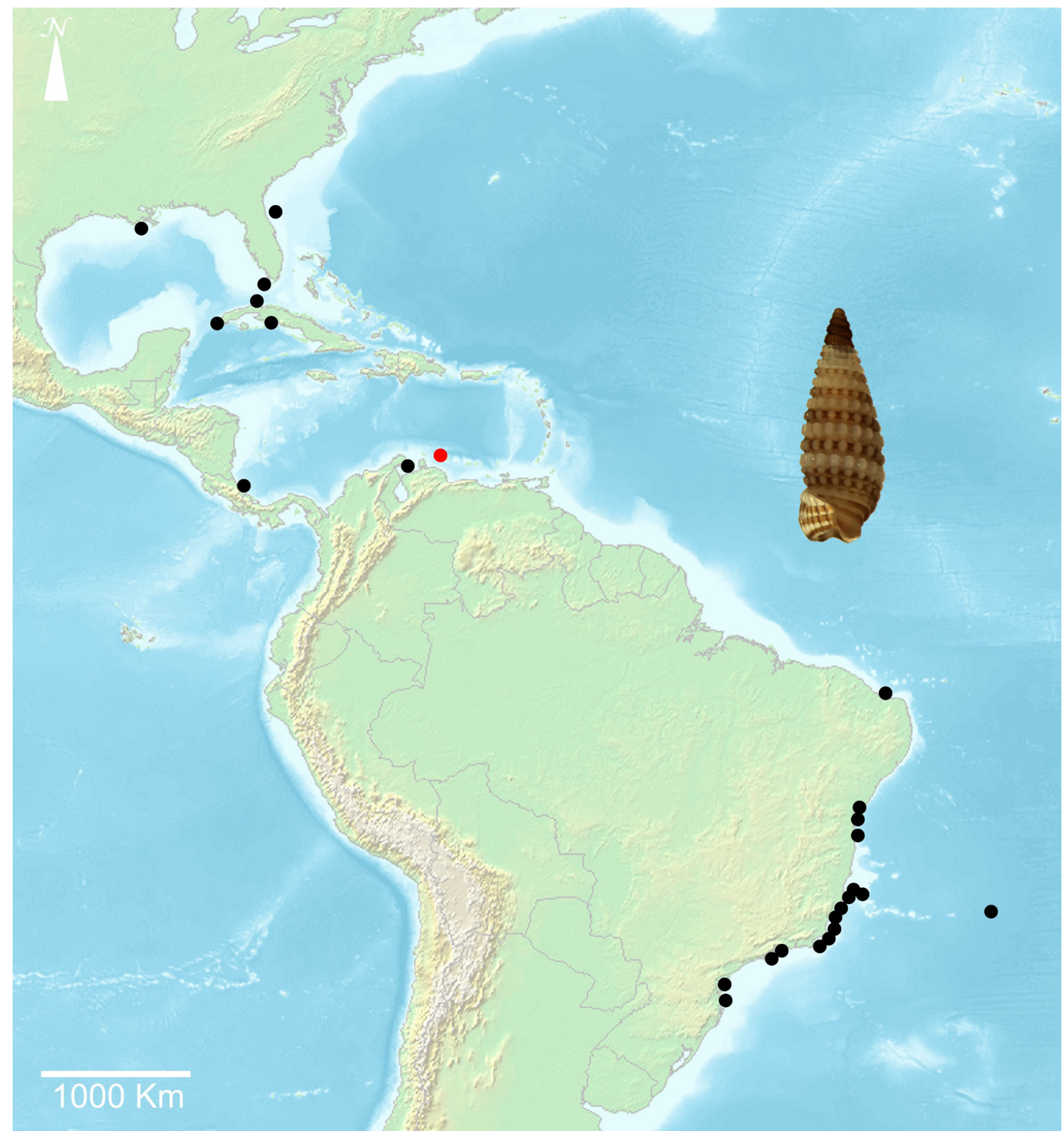

Fig. 78. Distribution map of Triphora ellyae De Jong \& Coomans, 1988; red circle = type locality. 


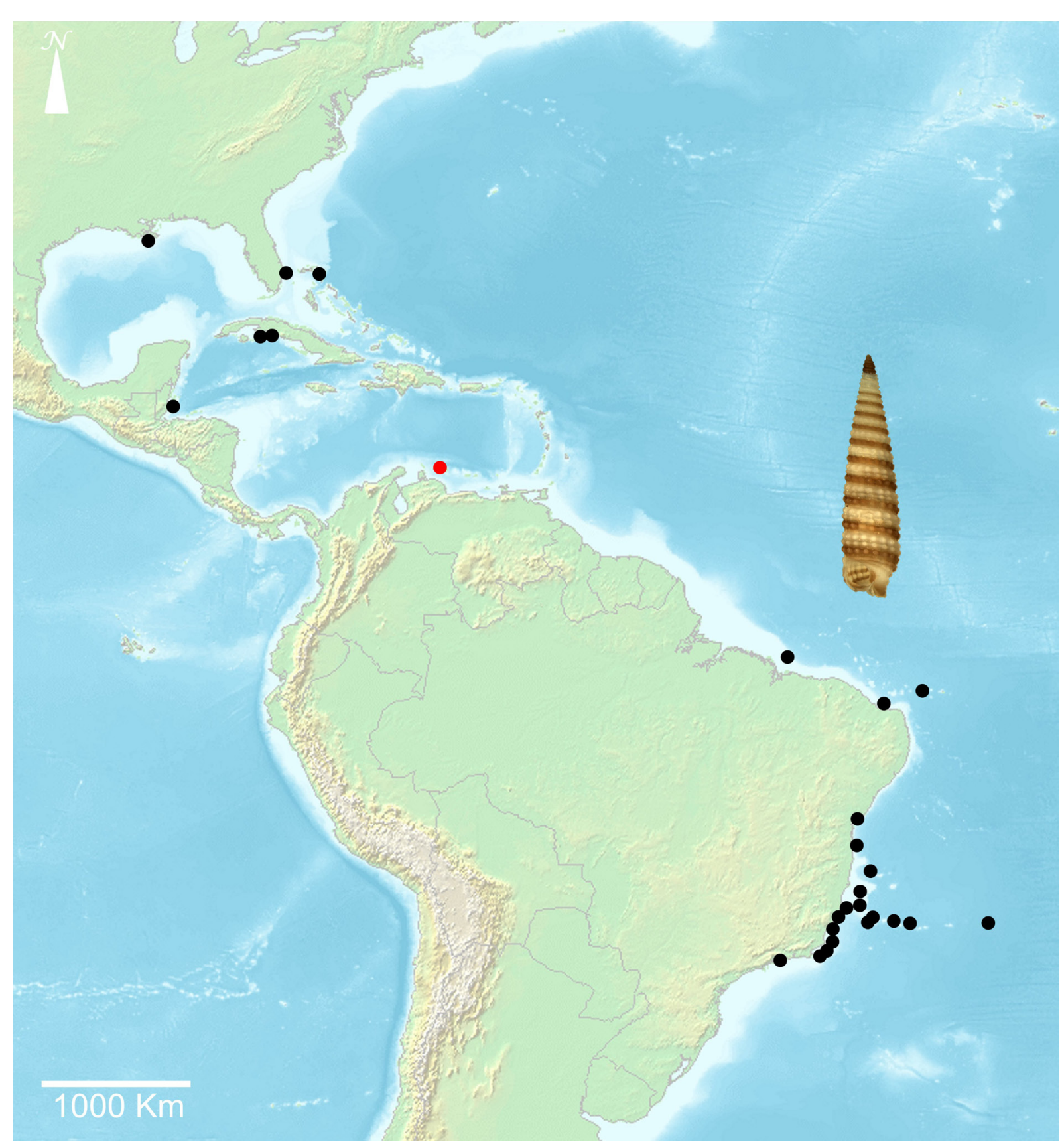

Fig. 79. Distribution map of Triphora elvirae De Jong \& Coomans, 1988; red circle = type locality. 


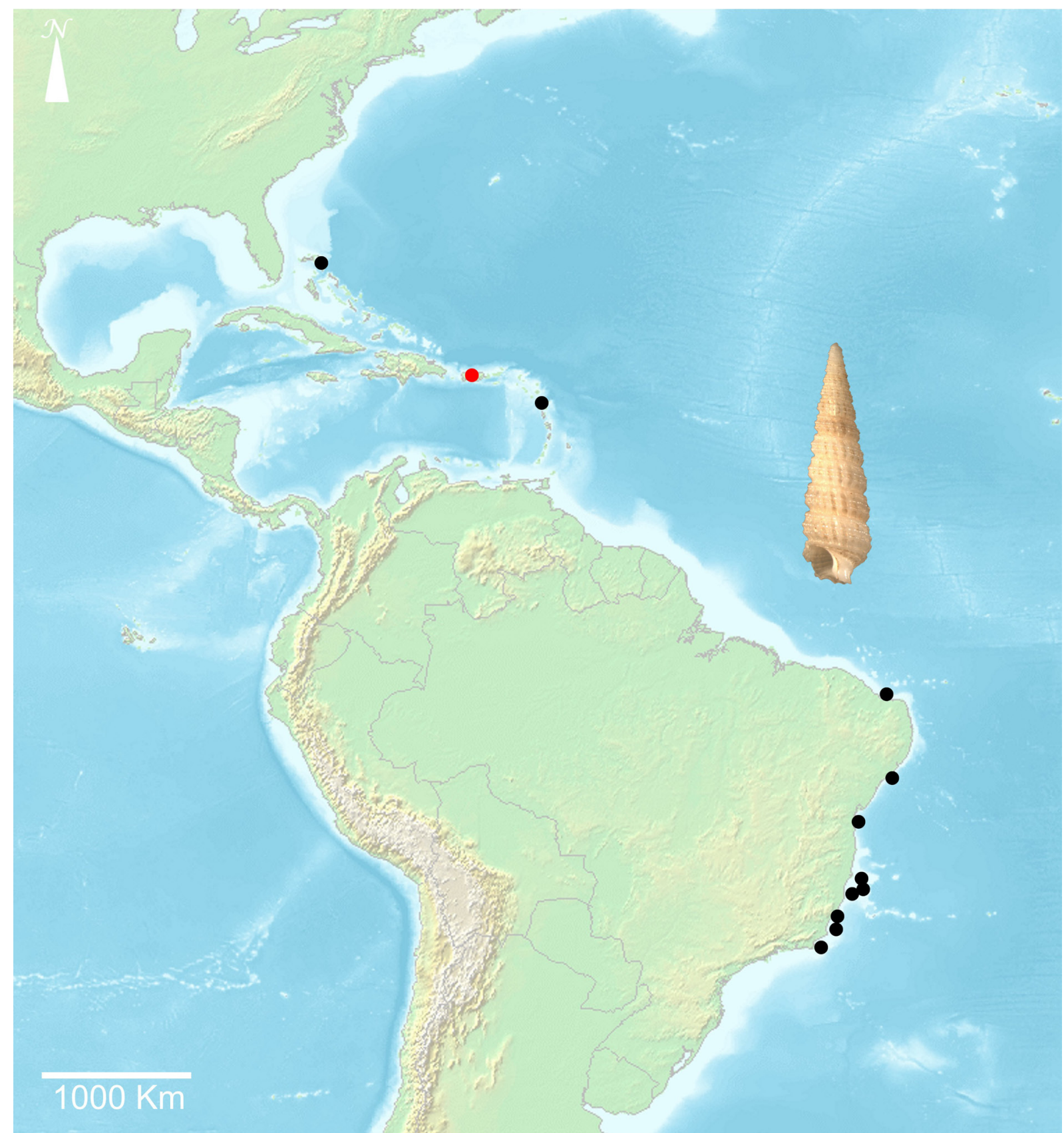

Fig. 80. Distribution map of Triphora portoricensis Rolán \& Redfern, 2008; red circle = type locality. 


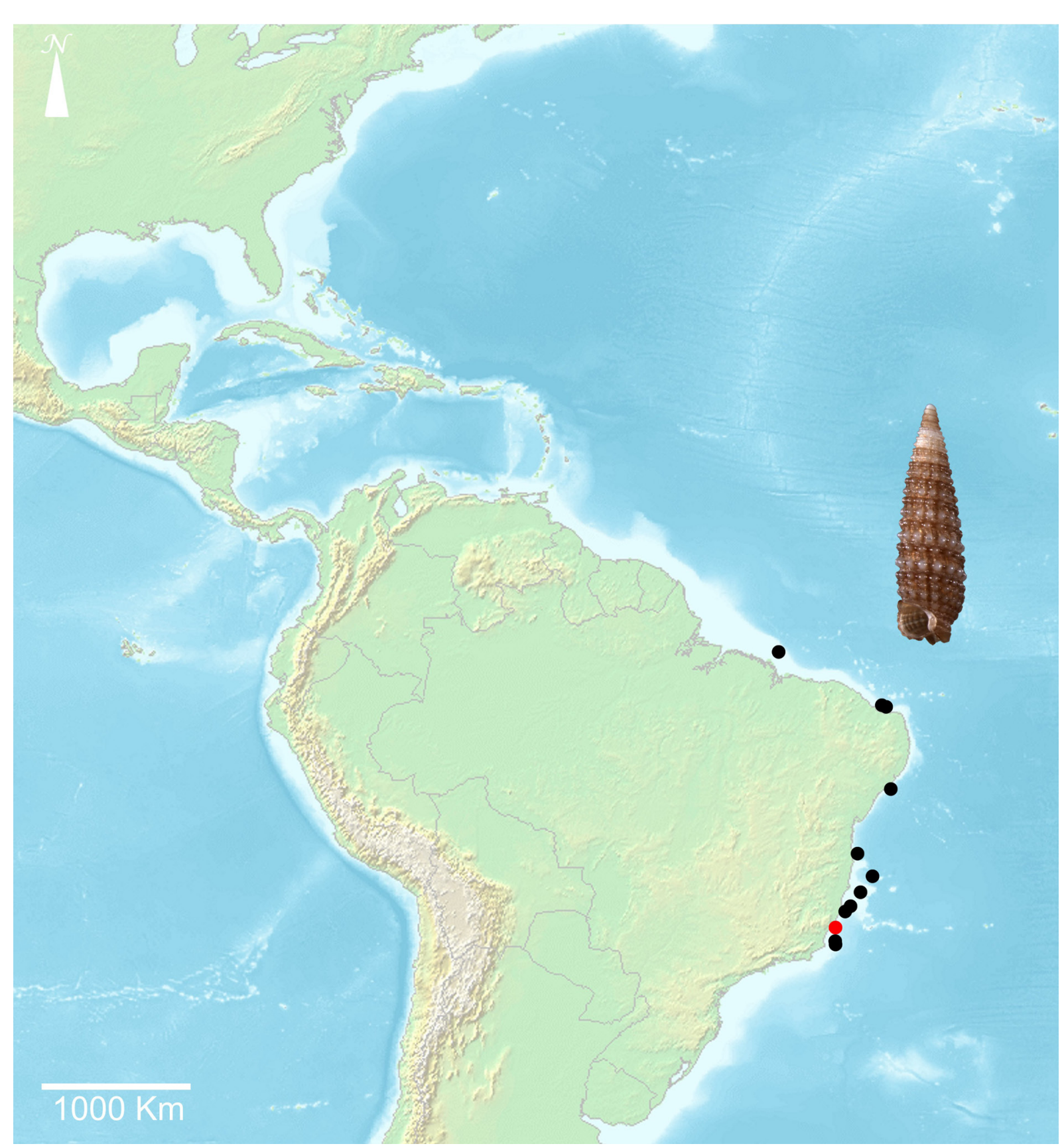

Fig. 81. Distribution map of Triphora scylla Fernandes \& Pimenta, 2015; red circle = type locality. 


\section{Discussion}

After more than six decades of published records of triphorids from Brazil, since Lange-de-Morretes (1949), 13 species were known until 2010; this number actually decreases to 11 because two species with unknown apexes and, therefore, unsubstantiated identifications, were recorded by Rios (1975, 1985) (Fernandes \& Pimenta 2019b). From 2011 to now, the number increased to 65, revealing the importance of taxonomic revisions to update our knowledge of the real diversity of regional biota. This is particularly evident when dealing with micromolluscs, which were often neglected in the past due to inherent difficulties in their study. Pending future thorough taxonomic revisions of "Caribbean" species to complement the study of Triphoridae from the western Atlantic, 31 of the 65 species $(\sim 48 \%)$ are presumably endemic from Brazil.

Several species distributed from the "Caribbean" to Brazil show distinct gaps in their known geographical range. In most cases, this does not reflect absence of occurrence but merely absence of studies. For example, the region comprising Mexico to Nicaragua has scattered records of triphorids (e.g., Vokes \& Vokes 1983; Rolán \& Cruz-Ábrego 1996; Rolán \& Luque 1999), and certainly harbors more species than currently known. The arc of the Lesser Antilles, which provides an interesting comparison of triphorids shared with Puerto Rico and Hispaniola, is just recently being evaluated (e.g., Rolán \& FernándezGarcés 2015; Lamy \& Pointier 2018). The most noticeable gap of knowledge comprises the region from Venezuela to the Guyanas, which is severely influenced by the freshwater discharge of the OrinocoAmazon basin and is crucial to fulfill (or not) many gaps of geographical ranges of species shared between northwestern and southwestern Atlantic. Some gaps are also present in Brazil, since most taxonomic effort was concentrated in its southeastern region. The taxonomic descriptions of several triphorids from the western Atlantic in the last decades may explain some disjunct distributions, and material of these new species is possibly 'awaiting' to be analysed in scientific collections. However, the local absence of triphorids may also be related to the absence of specific sponge hosts in a certain area. It is also clear that some great disjunct ranges may be derived from the unrecognized existence of more than one species, although masked by a high similarity of shell features.

The Brazilian coast is subdivided into different provinces according to broad biogeographical analyses (references in Barroso et al. 2016). In a global comparison, Spalding et al. (2007) proposed the provinces of North Brazil Shelf-NBS (Orinoco-Amazon basin), Tropical Southwestern Atlantic-TSA (Piauí to Cabo Frio - northern Rio de Janeiro, southern Campos Basin) and Warm Temperate Southwestern Atlantic-WTSA (Cabo Frio to the mouth of Rio Negro, Argentina). The total number of triphorids in each province shows that 45 species $(\sim 69 \%)$ are tropical (occurring in NBS and/or TSA), 18 species ( 28\%) are tropical but extend southwards into subtropical waters, and only "Inella" sp. 3 and Strobiligera santista are restricted to the WTSA province (Fig. 82A). Species present in the "Caribbean" and here recorded only in TSA are presumed to also occur in NBS.B

The majority ( $79 \%)$ of the 33 planctotrophic species is distributed over two or three provinces in Brazil (Fig. 82B), whereas most ( $56 \%)$ of the 32 non-planctotrophic species is limited to a single province or to oceanic islands (Fig. 82C); this follows the general trend that planctotrophic developers present a wider geographical range than non-planctotrophic ones (Jablonski \& Lutz 1983; Nützel 2014). These figures may be misleading, however, because a widespread species occurring from the "Caribbean" to Rio de Janeiro will be counted for only two provinces, the same for a species that occurs for example from Maranhão to Ceará (i.e., S. unicornium; Fig. 72). The reduced number (11) of planctotrophic species common to all three provinces is possibly not related to limited larval spreading, but to survivorship outside optimal conditions (see below). The spreading of lecithotrophic species over two or three provinces may be misleading, because of uncertain taxonomic assignments due to the absence of available soft parts. The numbers of planctotrophic (33) and non-planctotrophic (32) species in Brazil 

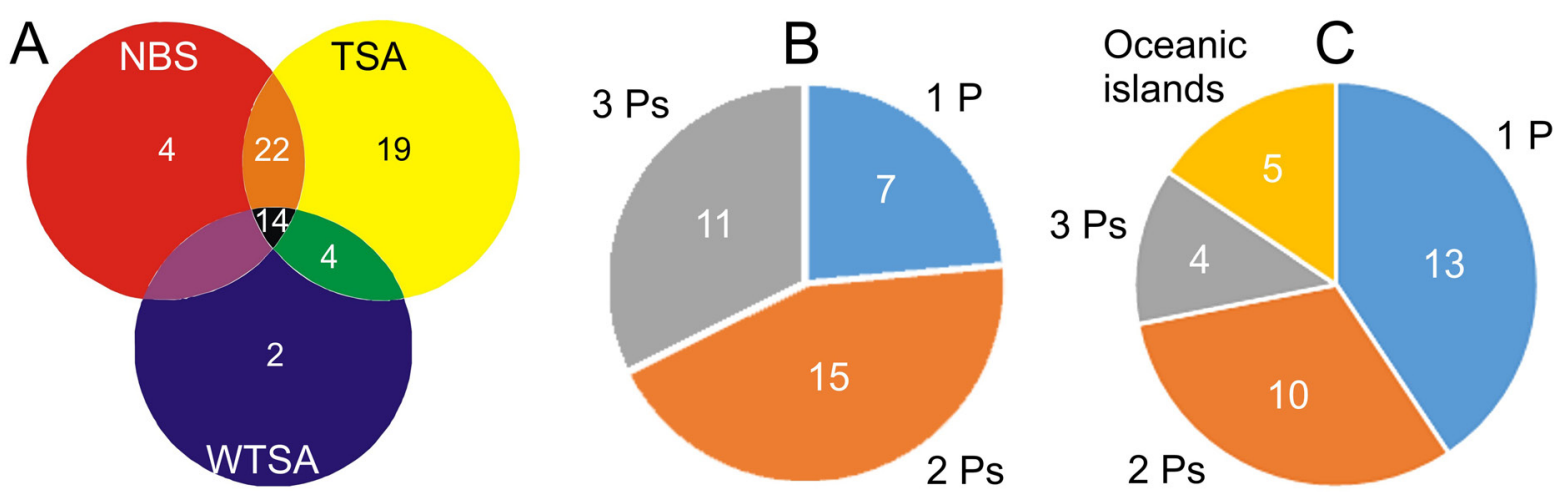

Fig. 82. Distribution of triphorids in Brazil according to the marine provinces of Spalding et al. (2007). A. Number of species in each province: NBS = North Brazil Shelf; TSA = Tropical Southwestern Atlantic; WTSA = Warm Temperate Southwestern Atlantic. B. Range of planctotrophic species in Brazil; ' $n$ ' Ps refer to species present in $n$ provinces. C. Range of lecithotrophic species in Brazil (those exclusively living near oceanic islands were set apart).

are very similar to the 67 species (34 planctotrophic, 33 non-planctotrophic) with known protoconch reported in southern Australia (Marshall 1983).

Campos Basin, in southeastern Brazil, comprises 42 of the 65 species ( $65 \%)$ and may reflect a speciose ecosystem rather than an artifact of intensified sampling effort (Fernandes \& Pimenta 2019b). Shallow and midwaters of the continental shelf of Campos Basin have a clear predominance of Similiphora intermedia, with Inella apexbilirata dominating the lower layers of the shelf. Perhaps the most evident spatial dominance of a triphorid in Brazil is observed in Cosmotriphora melanura, which is almost omnipresent along the seamounts of the Vitória-Trindade Chain (Fernandes et al. 2013), probably due to its longer larval duration (Fernandes \& Pimenta 2017b). Other species seem to have patchy distributions, like Iniforis pseudothomae.

Barroso et al. (2016) proposed that a gradual faunal transition of marine 'prosobranchs' occurs between southern Bahia and Santa Catarina, instead of the abrupt transition zone at Campos Basin (Spalding et al. 2007: fig. 1). The mix of tropical and subtropical/upwelling waters in Campos Basin (between Espírito Santo and Rio de Janeiro), in addition to the considerable freshwater discharge and the complex marine environment (Barroso et al. 2016), abruptly limit the range of 10 tropical planctotrophic triphorids (Fig. 83). A gradual limitation of the range of other tropical species emerges southwards (Fig. 83), comprising the ecoregion referred to as "Southeastern Brazil" by Spalding et al. (2007), which is influenced by the water temperature decrease during winter south of Rio de Janeiro (Miloslavich et al. 2011). Metaxia taeniolata, Monophorus verecundus sp. nov. and Triphora elvirae apparently do not extend their ranges south of the vicinity of São Sebastião (São Paulo). Four other species, i.e., Metaxia rugulosa, Monophorus olivaceus (with a single and controversial southern record; see Appendix), Sagenotriphora osclausum and Strobiligera inaudita reach the continental shelf of southern São Paulo State, although their shells are often found in very worn conditions in this meridional limit. Another hypothesis for this 'Step-by-step' restriction in the range of triphorids may be related to the scarcity of particular sponge hosts rather than reduced low-temperature tolerance of triphorids. Several tropical sponge species are scarce or absent south of Bahia and Espírito Santo (Solé-Cava et al. 1981).

In contrast, summer field work conducted by the authors in Santa Catarina State (southern Brazil) revealed high densities of living specimens of Marshallora spp., Nanaphora verbernei (Fig. 84A) and 
Nototriphora decorata (Fig. 84B), in addition to rare specimens of Triphora ellyae (Fig. 84C) and Similiphora intermedia (Fig. 84D, but with a hermit crab). Some species of Cerithiopsidae were also frequently sampled there. The local abundance of Triphoroidea suggests that these snails benefited

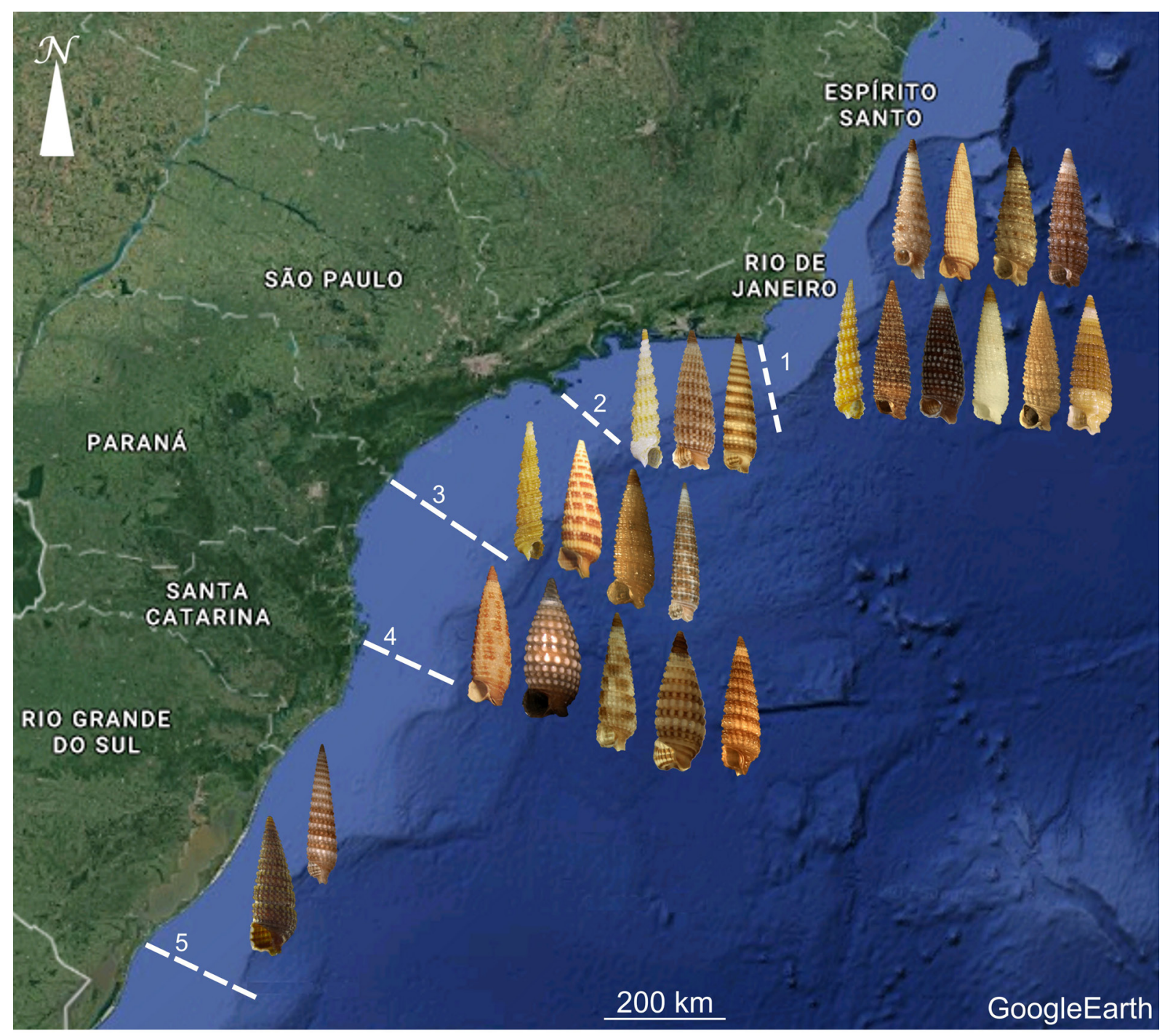

Fig. 83. Southern limits of planctotrophic, wide-range and tropical shallow-water triphorids from Brazil; the single exception is the lecithotrophic (but with a probable planctonic larva) Metaxia rugulosa (C.B. Adams, 1850). Illustrated shells are not necessarily from the southernmost end of their range. Species are cited from the left to the right, beginning with those situated at the top of each section: 1. Iniforis pseudothomae Rolán \& Fernández-Garcés, 1993, Latitriphora albida (A. Adams, 1854), Triphora atlantica Smith, 1890, Triphora scylla Fernandes \& Pimenta, 2015, Metaxia excelsa Faber \& Moolenbeek, 1991, Cheirodonta dupliniana (Olsson, 1916), Coriophora novem (Nowell-Usticke, 1969), Cosmotriphora melanura (C.B. Adams, 1850), Eutriphora costai Fernandes \& Pimenta, 2015, Marshallora ostenta Rolán \& Fernández-Garcés, 2008. 2. Metaxia taeniolata (Dall, 1889), Monophorus verecundus sp. nov., Triphora elvirae De Jong \& Coomans, 1988. 3. Metaxia rugulosa, Monophorus olivaceus (Dall, 1889), Sagenotriphora osclausum (Rolán \& Fernández-Garcés, 1995), Strobiligera inaudita (Rolán \& Lee, 2008). 4. Cosmotriphora arnoldoi Faber \& Moolenbeek, 1991, Nanaphora verbernei (Moolenbeek \& Faber, 1989), Nototriphora decorata (C.B. Adams, 1850), Triphora ellyae De Jong \& Coomans, 1988, Similiphora intermedia (C.B. Adams, 1850). 5. Triphora charybdis Fernandes \& Pimenta, 2015, Marshallora spp. Map adapted from Google Earth. 
from the scarcity of predators in higher latitudes (Valentine et al. 2002) and/or that particular sponges (specific to these micropredatory snails) dominate local rocky shores, or even that the Triphoroidea species succeeding in southern Brazil have a more generalized rather than a specialized diet.

A worn shell of Triphora charybdis from Rio Grande do Sul is here illustrated (Fig. 84E), but the tropical triphorids that reach the southernmost range in the western Atlantic are Marshallora spp., one of which is represented by a single and moderately preserved shell in Parcel do Carpinteiro, near Rio Grande city (M.R. Fernandes, unpublished data). The long sandy beaches in Rio Grande do Sul preclude the establishment of Marshallora spp. and these snails may be restricted to colonize the scattered rocky and shallow surfaces of 'parcéis' (outcrops). This genus is present as subfossils only in the mouth of Río de la Plata, between Uruguay and Argentina (Fig. 84F-J), revealing a population retraction probably due to the weakening of the warm Brazil Current during the Quaternary (Aguirre 1993; Martínez et al. 2006, 2013). Forcelli \& Narosky (2015) recorded the name M. nigrocincta for Uruguay, but illustrated a shell of Similiphora intermedia, not having detailed its origin or voucher material; the illustrated shell

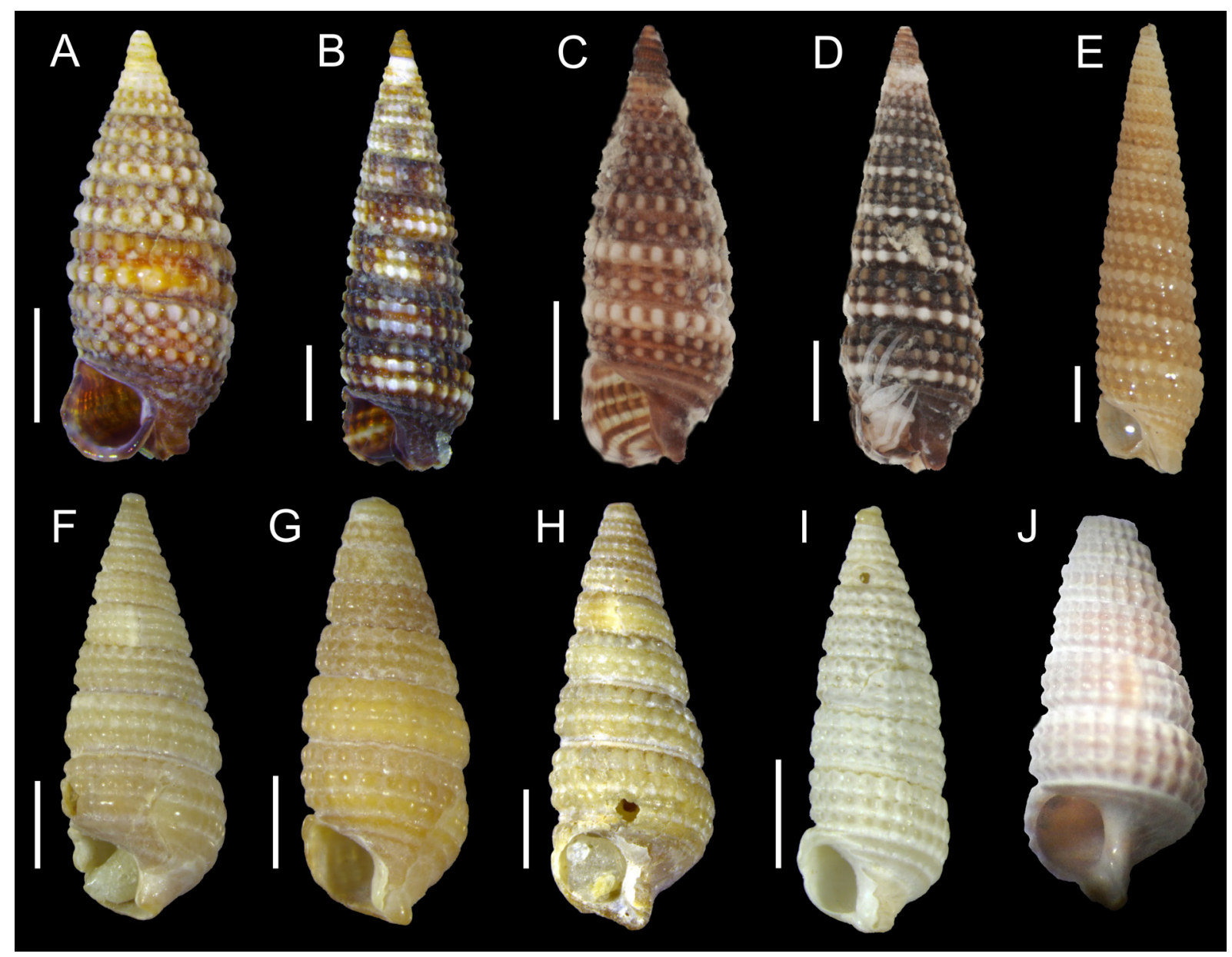

Fig. 84. Fresh and worn specimens found in southern Brazil and Uruguay/Argentina. A. Nanaphora verbernei (Moolenbeek \& Faber, 1989), MNRJ 28956*. B. Nototriphora decorata (C.B. Adams, 1850), MNRJ 28941*. C. Triphora ellyae De Jong \& Coomans, 1988, MNRJ 23259. D. Similiphora intermedia (C.B. Adams, 1850), MNRJ 23366. E. Triphora charybdis Fernandes \& Pimenta, 2015, MZSP 19331. F-J. Marshallora sp. F-I. MNHN-Mo 12959*, La Paloma, Rocha, Uruguay, E. Duarte leg., 6 Apr. 1959. J. MLP 26399, Cantera La Elvira, Buenos Aires Province, Argentina, M. Aguirre leg., 1983. Scale bars: $1 \mathrm{~mm}$.; J not to scale. 
might have been sampled in tropical waters, outside Uruguay. Similiphora intermedia was originally recorded from Uruguay by Figueiras \& Sicardi (1972) under the erroneous name Triphora pulchella (C.B. Adams, 1850), but then, all records of this species in Uruguay are doubtful and based on worn material.

At the other extremity of the western Atlantic, it seems that northeastern Florida (USA) represents the northernmost limit to several tropical and widespread triphorids. The well-recognized transition zone of Cape Hatteras, in North Carolina, seems to be the last frontier for the remaining tropical species (except Cheirodonta dupliniana, occurring northwards until Connecticut, USA (Fig. 29), and Marshallora nigrocincta), preventing them to reach the Cold Temperate Northwest Atlantic Province (Spalding et al. 2007). Similarly, some species have extended ranges in both extremities of the subtropical western Atlantic (e.g., M. rugulosa, M. taeniolata, $N$. decorata, S. osclausum and S. intermedia), although others inhabit subtropical waters only in the northwestern Atlantic (e.g., C. dupliniana, C. melanura and L. albida) or in the southwestern Atlantic (e.g., C. arnoldoi, S. inaudita and T. ellyae).

Several planctotrophic triphorids in northeastern Florida also colonized Bermuda, except Metaxia taeniolata, Cheirodonta dupliniana (which was often overlooked), Sagenotriphora osclausum and Similiphora intermedia; the three latter species did not spread over the Vitória-Trindade Chain either, in southeastern Brazil. The fast-flowing Gulf Current facilitates larval dispersal to Bermuda, albeit a reassessment of the material listed in Jensen \& Pearce (2009) may reveal species different from those currently recognized there, such as, for example, the erroneous identification of Marshallora nigrocincta (M.R. Fernandes, unpublished data). Metaxia rugulosa, which has a short-lived larva inferred from the protoconch morphology, might have been erroneously identified by Jensen \& Pearce (2009) for Bermuda regarding the previous description of Metaxia prompta by Rolán \& Fernández-Garcés (2008). Caution must be given to the record of Metaxia prompta from the Vitória-Trindade Chain (Fernandes \& Pimenta 2011), which could be an unnamed new species with a paucispiral protoconch very similar to that of the species from Bermuda, but originated from a different plancto-lecithotrophic transition. Similarly, records of Iniforis carmelae from Brazil could actually be derived from different ancestral populations of the planctotrophic species I. pseudothomae, which would have acquired lecithotrophy in oceanic islands or distant rocky outcrops. Without the knowledge of soft parts, shell features do not provide enough evidences to such ideas.

Several factors may trigger the plancto-lecithotrophic transition, such as the presence on isolated islands, in coastal lagoons, in the deep sea, narrow bathymetric ranges, strong offshore currents and much oligotrophic waters (which may hamper planctotrophic development) (Ellingson \& Krug 2016; Fernandes \& Pimenta 2019b). Hypothetical scenarios such as the replacement of planctotrophic individuals by non-planctotrophic ones or even long-lasting sympatry with lack (speciation) or maintenance of gene flow between individuals of different development modes (poecilogony) form an interesting field of research. The rare occurrence of poecilogony is regarded as representing brief periods of larval evolutionary transitions, or as a stable strategy for some species (Collin 2012; Knott \& McHugh 2012; Ellingson \& Krug 2016). The recent discovery of poecilogony in a few caenogastropod species (McDonald et al. 2014; Russini et al. 2020) provides a new stimulus for research in other families. Substantial modifications in the alpha-taxonomy of triphorids would be required if currently recognized planctotrophic and lecithotrophic sibling species are actually conspecific. Yet, until compelling evidence indicates otherwise, sibling species of Triphoridae are considered to reflect possible past poecilogonic events that led to the current species level divergence.

Species of Isotriphora are recognized by their typical paucispiral protoconch, indicative of intracapsular metamorphosis. With the exception of I. tricingulata, all species of Isotriphora that occur in Brazil are restricted to oceanic islands, and their development favours larval retention and increases self- 
recruitment and allopatric speciation (Leal 2000; Fedosov \& Puillandre 2012). However, it is intriguing to imagine a scenario in which a genus that acquired intracapsular metamorphosis spreads among isolated islands thus promoting subsequent speciation. This is the more surprising since Isotriphora is absent in the continental shelf of northeastern and southeastern Brazil. It seems more plausible that ancestral planctotrophic lineage(s) may have reached oceanic islands, and the simplification to a similar (but convergent) protoconch emerged. Once lecithotrophy emerges in gastropod lineages its reversion to planctotrophy is believed to be precluded (Bouchet \& Warén 1994), in spite of rare exceptions (Collin et al. 2007), thus the great evolutionary flexibility of the larval development of triphorids seems unidirectional. This hypothesis agrees with the existence of different types of teleoconch in species of Isotriphora from Brazil, with some of them showing late (I. onca, I. tigrina and I. uncia sp. nov.) or early (I. tricingulata and Isotriphora sp. 1) emergence of the median spiral cord, whereas I. leo sp. nov. has a late adapical cord, evidently reflecting different groups which are united by convergent larval development (Marshall 1983: 56). The polyphyly of Isotriphora will probably be confirmed after a comprehensive phylogeny.

The present study confirms or records for the first time the occurrence of several planctotrophic triphorids in the archipelagos of Fernando de Noronha or Atol das Rocas: M. excelsa, C. dupliniana, C. melanura, L. albida, M. olivaceus, $N$. decorata, S. albocaput sp. nov., T. atlantica and T. elvirae. In this case, absence of records evidently does not mean absence of occurrence, because the sampling of triphorids in Fernando de Noronha/Atol das Rocas was very sparse. Cosmotriphora melanura is the single triphorid that reached the isolated archipelago of São Pedro e São Paulo, which is possible by the supposedly prolonged larval development of this species (Fernandes \& Pimenta 2017b).

Two species from the continental shelf, Sagenotriphora albocaput sp. nov. and Similiphora lucida sp. nov., are apparently restricted to the region comprising the mouth of the Amazon River to Rio Grande do Norte State, agreeing with the Cearaian subprovince of Petuch (2013). These species do not extend their range northwards, because of the totally different environmental conditions (see below), and southwards their larvae may be not able to overcome the counter flow of the North Brazil Current, which sweeps the continental shelf above Paraíba State (Miloslavich et al. 2011). Strobiligera gaesona may adopt the deep waters of the Canopus Bank and adjacent seamounts in Ceará and Rio Grande do Norte as southernmost refuges. The rare newtoniellid Cerithiella sigsbeana (Dall, 1881) presents a similar geographical range to $S$. gaesona, recorded only from its distant type locality and to the Canopus Bank (Fernandes et al. 2015). Other deep-sea gastropods seem to be restricted from the northwestern Atlantic to Ceará/Rio Grande do Norte (Daniel Cavallari, pers. comm.), agreeing with the lower bathyal North Atlantic province of Watling et al. (2013).

The mouth of the Amazon River and the entire North Brazil Shelf province of Spalding et al. (2007) provide an interesting scenario for triphorids. Several species widespread in the western Atlantic are found there, apparently allowing a gene flow between northwestern and southwestern Atlantic populations. Two species ("Inella" vanilla and "Inella" sp. 4) are mainly or strictly found there, and two others (Sagenotriphora sp. 1 and Similiphora sp. 1) might be atypical morphs related to species with wide ranges in the western Atlantic (Sagenotriphora osclausum and Similiphora intermedia, respectively, both also present in the North Brazil Shelf province). The atypical marine conditions of this region include reduced superficial salinity levels over a wide range, the presence of mangroves along the shore, low light and oxygen levels, extremely high sedimentation and consequent dominance of soft/unstable substrata. The North Brazil Current attains a great speed near the Amazon River mouth, reducing sedimentation over the bottom; this, coupled with the scarcity of zooxanthelate corals in this region, enabled the formation of an extensive carbonate reef (with several endemic sponges) in the mid/outer continental shelf of this area, from Oiapoque (Amapá) to Parcel Manuel Luís (Maranhão) (Moura et al. 2016; Francini-Filho et al. 2018). This reef lies at a depth of 70-220 m (Francini-Filho 
et al. 2018), occasionally up to a depth of $30 \mathrm{~m}$ (Moura et al. 2016), not being reachable to shore species such as Marshallora spp., although it may function as a biogeographical corridor to species common to the northwestern and southwestern Atlantic (Moura et al. 2016). Particularly for S. osclausum vs Sagenotriphora sp. 1 and S. intermedia vs Similiphora sp. 1, three hypothetical scenarios seem likely: (1) Sagenotriphora sp. 1 and Similiphora sp. 1 are merely ecological forms resulting from the interference of atypical environmental conditions in the normal production of the shell of S. osclausum and S. intermedia, e.g., phenotypic plasticity; or (2) they are new species, adapted to feed on specific endemic sponges; or (3) the reef is promoting a parapatric process, allowing a restricted gene flow between slightly divergent populations (Moura et al. 2016), with the emergence of a hybrid zone.

Of the 65 triphorid species in Brazil, 58 species ( $89 \%)$ inhabit the continental shelf, contrasting with only seven $(\sim 11 \%)$ from the continental slope. Two of the 33 planctotrophic species $(6 \%)$ are restricted to the continental slope, whereas five of the 32 lecithotrophic species $(\sim 16 \%)$ are mainly found in the deep sea. The depth range of some species may be much wider than suggested here owing to limited sampling, whereas the depth range of others might have been erroneously exaggerated due to post mortem displacement (this error was minimized by disregarding depth records of worn shells) or by lumping different species under a single name. Notwithstanding this, it is clear that several triphorids are present in a large extension of the continental shelf $(0-150 / 200 \mathrm{~m})$, whereas others are restricted to narrow ranges in the shore or in mid/outer layers of the continental shelf (Fig. 85). Brazilian coastal waters present a thermocline between 50-100 m (Miloslavich et al. 2011), which, coupled to the generalized

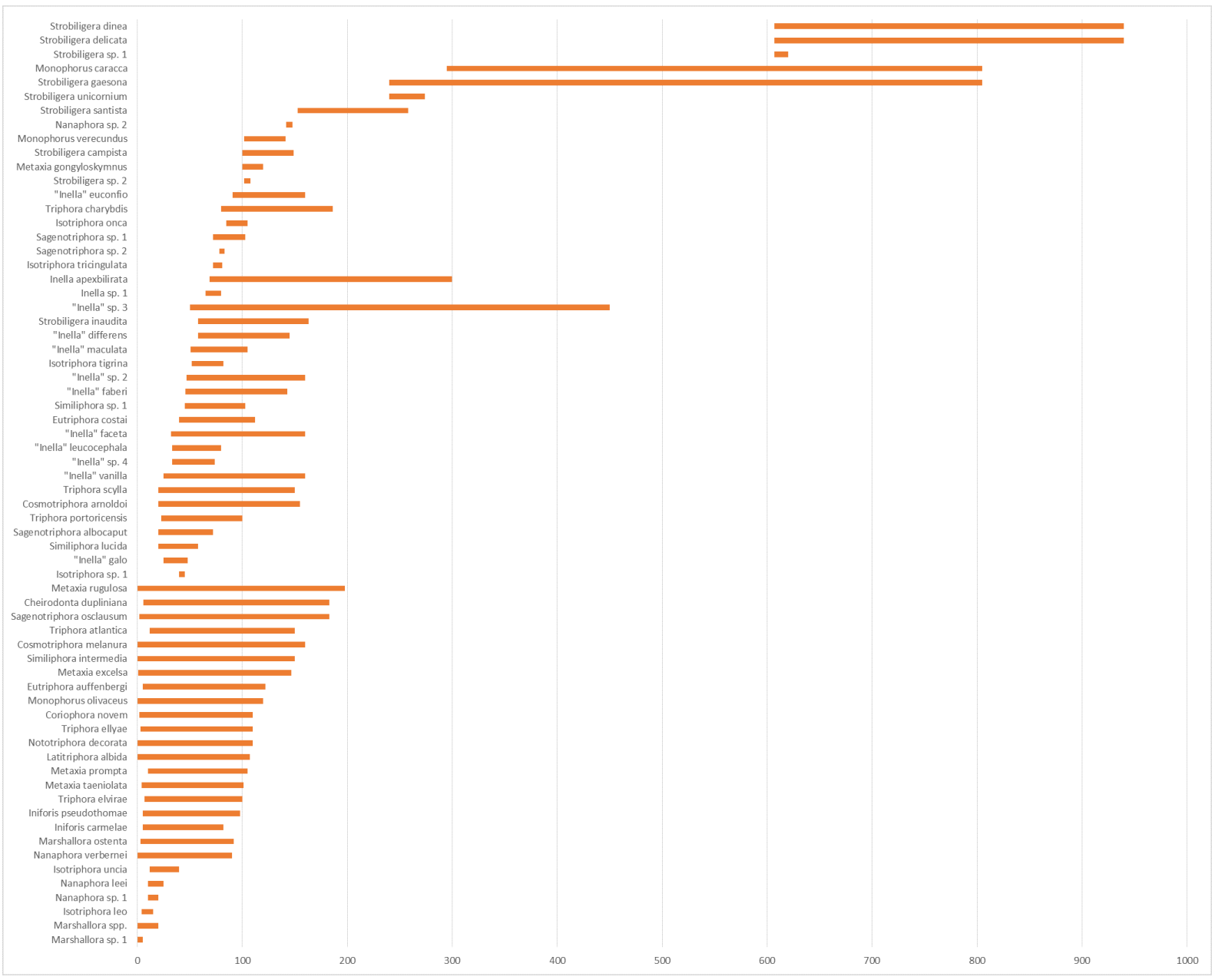

Fig. 85. Bathymetric range of triphorids from Brazil. 
transition of fauna occurring near the 'twilight zone' (Pyle 2001), seems to restrict several triphorids to mid or deeper layers of the shelf. Depth zonation also evidences that many species can be sampled by free diving, whereas many others require SCUBA diving and/or dredging (Fig. 85).

\section{Perspectives}

The daunting task to review the taxonomy of speciose families of marine molluscs demands a complete survey of malacological collections and an extensive search for specialized literature. Even when a taxonomic revision is supposedly concluded, it is certain that some species will still be discovered in the near future. Currently, 65 species of Triphoridae are known from Brazil, although some of them still require a greater amount of material to enable formal descriptions. This high number of species is below or similar to that of other speciose (and taxonomically evaluated) families of parasite/micropredator gastropods in Brazil, like Pyramidellidae (140 species, Alexandre Pimenta, pers. comm.), Eulimidae (about 120 species, Leonardo Souza, pers. comm.) and Epitoniidae (64 species, Andrade 2017).

Some perspectives for the study of Triphoridae will be discussed in the following pages, encompassing urgently required efforts and ideas to be developed in the next decades.

\section{(1) Phylogeny}

Several parts of this study emphasized the urgent need of phylogenies to solve complicated situations related to genus or species delimitations. A single morphological attempt to resolve the phylogeny of triphorids was made by Kosuge (1966), who relied mainly on radular characters to organize some groups of Triphoridae. Nützel (1998) studied the phylogeny of the "Ptenoglossa", a group currently considered polyphyletic (Ponder et al. 2008), and suggested that the dextral species of the so-called "Triforidae" (i.e., Trituba Jousseaume, 1884) are the sister-group to Triphoridae. The astonishing similarity between Trituba and triphorid fossil genera such as Epetrium Harris \& Burrows, 1891 does suggest this relationship.

As argued by Marshall (1983: 19) "as presently understood, triphorines exhibit a character mosaic of such intricate complexity that it would be unwise to attempt separation of further subfamilies with our present limited state of knowledge". Supposed primitive features such as multispiral protoconchs with a smooth spiral zone, teleoconch with late adapical spiral cord, operculum with nucleus slightly eccentric and undifferentiated teeth of radula are present in species of the "Inella group" (Marshall 1983). Another main group of Triphoridae seems to be defined by the development of long and closed tubular canals, distinct microsculpture in the teleoconch, very late emergence of median spiral cord of the teleoconch and operculum with a peculiar peg-like projection in some species. Genera such as Iniforis, Coriophora, Mastonia and Mastoniaeforis belong to this group, and a future revalidation of the subfamily Iniforinae Kosuge, 1966 may be considered. The undifferentiated teeth morphology of Iniforis (and the possibly related Isotriphora) is also regarded as a primitive condition. Clearly, without any objective phylogenetic investigation, these ideas are meaningless.

\section{(2) Biogeography}

The assessment of the biogeography of triphorids at local or regional scales can only be achieved once the species-specific associations of these micropredators/parasites to the particular sponges that serve as preys/hosts are better known. Citing two examples from Brazil, it is uncertain if some species of Triphoridae are absent from the Vitória-Trindade Chain or below Campos Basin respectively because of limited larval dispersal or limited tolerance to subtropical waters, or merely because their primary sponges are not present in these regions. On the other hand, the sharing of a species between the continent and oceanic islands means that the triphorid has feeding options in both localities, its pelagic larval development lasts long enough to disperse across the ocean, and that distinct abiotic and biotic factors do not limit its survivorship and reproduction. 
Some interesting patterns emerge when considering triphorids on a global scale. Several well-recognized genera are restricted to the Indian Ocean and the western/central Pacific, such as Euthymella, Mastonia, Mastoniaeforis and Viriola, many of them possibly related to the hypothetical "Iniforis group". Conversely, genera such as Cosmotriphora, Marshallora and Similiphora are known only from the Atlantic Ocean. All these genera may have had a 'recent' formation suggested by their differentiated teeth morphology (Marshall 1983), having originated after or during the closure of the Tethys Sea (i.e., between the Late Oligocene and Early Miocene), an event that separated the marine fauna of the IndoPacific and the Atlantic (Vermeij 2012). The opposite is seen for supposed old/middle-aged genera such as Inella, Monophorus, Iniforis and Isotriphora, which are present worldwide and show a more or less undifferentiated teeth morphology.

\section{(3) Alpha-taxonomy}

The taxonomy of triphorids is poorly studied in several regions of the globe. For example, the two African coasts (except South Africa) and the Indian coast were never target of revisions. Even the Coral Triangle, which lies between the well-studied areas of Japan (e.g., Kosuge 1966) and Australia (e.g., Laseron 1958; Marshall 1983), will certainly reveal new data after a comprehensive revision. A notorious case is the eastern Pacific, with several old and worn types that require a complete investigation prior to the descriptions of new species (Fernandes \& Araya 2019).

Most descriptions of triphorids in the last decades came from the western Atlantic, despite the huge diversity of these snails in the western and central Pacific. Other families of microgastropods that constitute the so-called 'Big Five' are being intensively studied from this region in the last years (e.g., Peñas \& Rolán 2010; Cecalupo \& Perugia 2013), especially after the great amount of material sampled by the expeditions conducted by the MNHN team. The chaotic situation and high numbers of already described triphorids of the western and central Pacific, in many cases avoiding a link between worn types and newly sampled specimens, encouraged the current reevaluation of types described from these regions (e.g., Albano \& Bakker 2016; Albano et al. 2019). The same problem applies to the well-known "Caribbean" triphorid fauna, where several species are exclusively recognized by their old and worn types, requiring reevaluations and much more samplings.

Species shared between Brazil and the "Caribbean" are prone to have their DNA analysed in order to clarify if there is any genetic break along their distributional range, as observed in a complex of species in Marshallora (M.R. Fernandes, unpublished data). The study of fossils/subfossils from Brazil (Fig. 86A-E) may also reveal new findings: no fossil species of Triphoridae was recorded so far (Maury 1988; Simone \& Mezzalira 1994), but this is probably a result of the scarcity of paleontological studies focusing on the discovery of microgastropods in Brazil.

\section{(4) Anatomy}

The image reconstruction of the internal anatomy of triphorids by micro-tomography and histological serial sectioning is a step forward to the unraveling of the morphological diversity of this speciose family. Although these techniques may demand a reduced working time if compared to classical drawings on camera lucida, they have particular technical issues and require great financial support.

A possible anatomical contribution to the biology of triphorids is the histology of female gonads to determine whether a continuous or seasonal reproduction occurs, especially when applied concomitantly to population dynamics procedures. Regarding the histology of male gonads, the ultrastructure investigation of the triphorid spermatozeugmata may reveal another level of generic comparisons (Healy 1990), especially if different triphorid genera indeed show an exclusive presence of spermatozeugmata or of true spermatophores (Robertson 2007). 


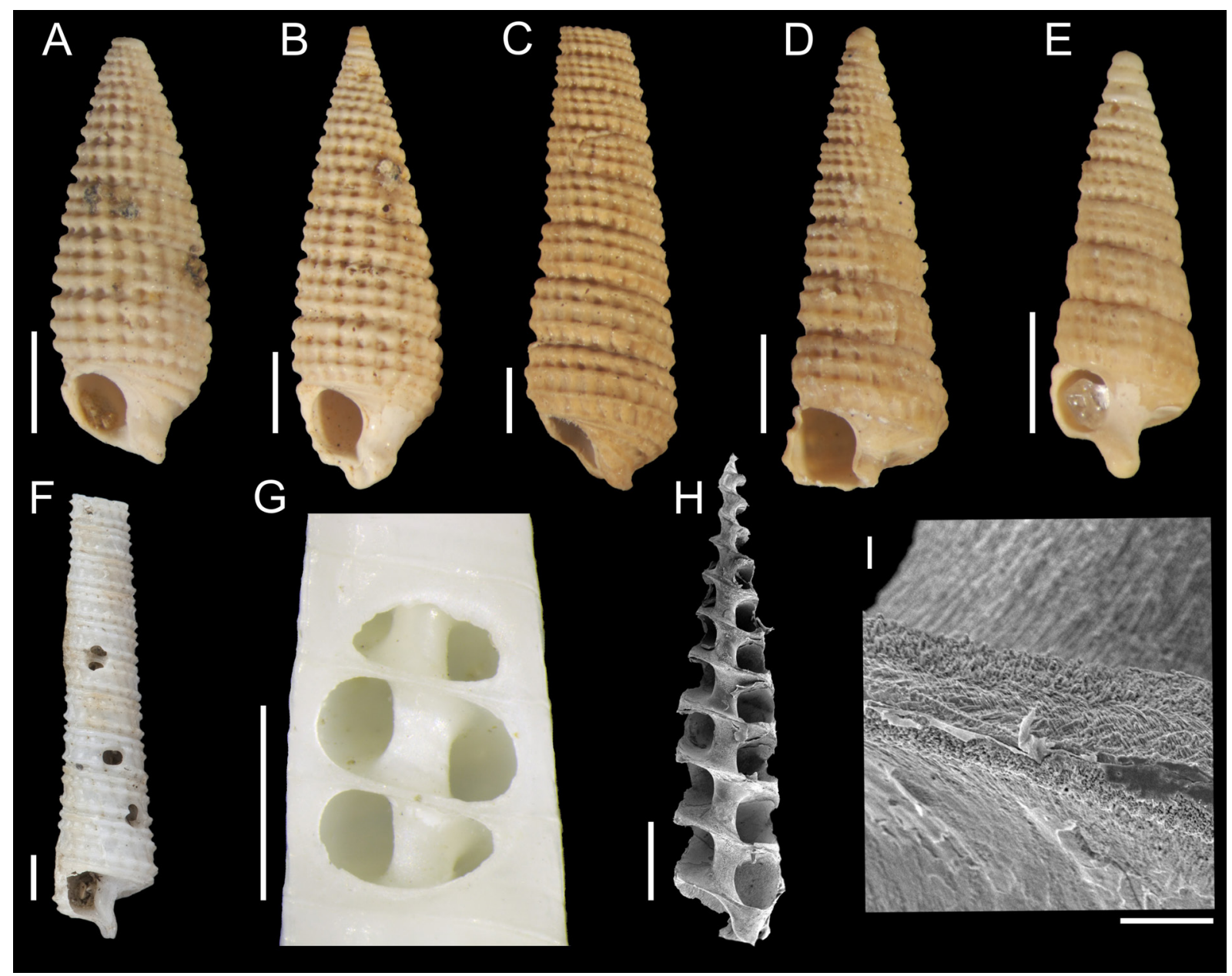

Fig. 86. Some perspectives of studies with triphorids. A-E. Subfossils of 'Triphora' spp. from the place currently known as 'Aterro do Flamengo', Rio de Janeiro, Brazil: MZSP 83618 (A), MZSP 42715 (B-E). F. Shell of Inella gigas (Hinds, 1843) with predation marks, obtained from Fernandes \& Pimenta (2019b). G. Shell of Strobiligera gaesona (Dall, 1927) with a large predation mark. H. SEM micrograph of the columella of Cosmotriphora melanura (C.B. Adams, 1850), MNRJ 33138*. I. SEM micrograph of shell layers of the columella of Nototriphora decorata (C.B. Adams, 1850), MNRJ 32763*. Scale bars: $\mathrm{A}-\mathrm{H}=1 \mathrm{~mm} ; \mathrm{I}=50 \mu \mathrm{m}$.

\section{(5) Spongivory}

We completely ignore the relationships of species of Triphoridae with particular sponges except for a few records and unpublished photographs. It is uncertain, for example, whether most triphorids are truly specialized on one or a few species of Porifera or whether they are generalists (Marshall 1983: 7). The observation of triphorids moving between one and another sponge may confirm their micropredatory performance (suggested by gonochorism and the ubiquitous presence of a radula), whereas the observation of a more sedentary triphorid on a particular sponge specimen will advocate for the habit of parasitism (Poulin 2011). The discovery of other feeding modes in Triphoridae beyond spongivory would not be a surprise; for example, Warén \& Bouchet (2001) suggested that a deep-water cerithiopsid may have a modified feeding on tube worms living in hydrothermal vents. Nützel (1998) suggested that Triphoridae and Cerithiopsidae may occupy different sponge hosts, which would have originated divergent radular and other alimentary traits. 
A study aiming at detecting what sponges are preferred in the diet of triphorids should employ complementary techniques beyond fortunate in situ records of associations, such as: selective samplings, with the material brushed from particular sponge species being held in separate devices; histology of the stomach content (or fecal pellets) of triphorids in search of spicules; laboratory experiments to test the preference of triphorids for different preys/hosts; the analysis of Porifera collections in search for associated triphorids. Ideally, traps encompassing large blocks of sponges could be designed to evaluate larval settlement of triphorids. The observation of the mechanism employed during feeding may reveal strategies other than the penetration of the proboscis into the osculum, like the excavation of large holes in the sponge (Marshall 1983).

\section{(6) Defensive mechanisms}

Triphorids display distinct defensive mechanisms, such as the nodulose teleoconch sculpture (probably reducing shell damage and drilling), a small aperture, a deep withdraw into the posterior whorls of the shell when threatened (reducing shell entry attacks), and they possibly obtain refuge in the canals of sponges. An interesting consequence of their sinistral configuration might be a greater avoidance of predation by right-handed crabs (Dietl \& Hendricks 2006; Vermeij 2015). Laboratory tests can be conducted to compare similar triphorids and cerithiopsids facing dextral and sinistral crabs (Shigemiya 2003).

A comparison of predation marks in shells of Triphoridae species from shallow and deep water, whether they are drill holes or repaired peristomes, would be interesting. Some species from the Brazilian slope seem to be particularly affected by drill holes, especially Strobiligera gaesona (Fig. 86G), which has a smooth shell and may be consequently more prone to be attacked by drilling gastropods (Fernandes \& Pimenta 2019b).

Despite all possible benefits that small-sized gastropod lineages may obtain after acquiring larger dimensions in the deep sea, such as higher reproductive output (McClain \& Crouse 2006; McClain et al. 2006), deep-sea triphorids may acquire particular gains when evolving gigantism (Fernandes \& Pimenta 2017a). An extremely high-spired shell may facilitate a deep withdraw into the posterior whorls of the shell, reducing predation risks, and may hamper the chance of being dislodged from its prey/host (McClain \& Crouse 2006). In fact, McClain et al. (2012) found that the biovolume of triphorids seems to be slightly greater in regions with reduced carbon flux (like the deep sea) than in productive regions in the northwestern Atlantic.

The interspecific variation in shell color of triphorids is remarkable, not only the tonality but especially the coloration pattern (e.g., axially or spirally stained, uniformly or sparsely distributed). One logical explanation to such variation is the camouflage of these snails in particular sponges, avoiding their detection by visual predators. Pigments aligned with spiral or axial cords were also suggested to be a proper cost/benefit ratio related to energy production and shell strenghtening (Rosenberg 1997). The widespread occurrence of brown shells of triphorids in shallow subtidal zones, however, could be related to specific shell pigments that may offer protection against light damage (Williams et al. 2016).

\section{(7) Shell morphology}

The diversified shell shape of triphorid genera (from small and globose to fusiform and extremely elongated forms) are suitable for 3D morphometry, which may be able to detect shifts between species or genera. In addition, the study of the columella without damaging the shell (Fig. 86H) is possible by micro-tomography, which, complemented by SEM/TEM images of the deposition of shell layers (Fig. 86I), may provide important insights into the taxonomy of this family. 


\section{(8) Sexual dimorphism}

Marshall (1983:3) indicated that some species of Triphoridae present two distinct size classes, suggesting that sexual dimorphism may play an important role in shell shape, a common feature observed in many other gastropods. We know nothing about sexual dimorphisms in Triphoridae, raising doubts as to what extent radular variation may reflect differences between sexes, e.g., as observed for Strombidae (Mutlu 2004), Muricidae (Fujioka 1982), Buccinidae (Matthews-Cascon et al. 2005) and Columbellidae (deMaintenon 2004), although sex differentiation of triphorids requires the study of their internal anatomy because males are aphallic (Kosuge 1966). To link a possible morphological sexual dimorphism to ecological differences (e.g., host preference) between males and females is another interesting subject to be explored.

\section{(9) Larva and early ontogeny}

Fernandes \& Pimenta (2017b) raised hypotheses for the larval development of triphorids, including: modifications of the larval shell color of some species by reduced available food during the planctonic stage; some species seem to have a prolonged larval development; and spontaneous metamorphosis may proceed without any substrate in some species. A few studies described the early ontogeny of cerithiopsids (Cipriani et al. 1994; Collin 2004), but data about the spawning and rearing of triphorids are limited to the observations of Pelseneer (1926), Lebour (1933) and Fernandes \& Pimenta (2019b). The description of the sequential stages of the triphorid development is entirely lacking, just like studies on triphorid larval ecology.

\section{Acknowledgements}

Many curators and technicians provided photographs or access/loans of types and ordinary material: Dr Adam Baldinger (MCZ), Dr Alberto Riccardi (MLP), Dr Andreia Salvador (NHMUK), MSC. Aramys Cesar (UNICAMP), Dr Carmen Parisotto (UFS), Dr Cléo Oliveira (IBUFRJ), Dr Cristina Rocha-Barreira (UFC), Dr Daniel Abbate (MZUSP), Dr Ellen Strong (NMNH), Dr Erika Montoya (INVEMAR), Dr Fabrizio Scarabino (CURE), Dr Harry Lee, Dr John Slapcinsky (FLMNH), Dr José Carlos Barros (UFRPE), Dr José H. Leal (BMSM), Dr Leslie Skibinski (Cornell University), Dr Luiz Ricardo Simone (MZUSP), Dr Mandy Bemis (FLMNH), Dr Marien Faber, Dr Paula Spotorno (MORG), Dr Philippe Bouchet (MNHN), Dr Rafael Araujo (MNCN), Dr Sonia Barbosa (UERJ) and Dr Thelma Dias (UEPB). Camila Messias (MNRJ) helped us with the SEM micrographs. The 'Conselho Nacional de Desenvolvimento Científico e Tecnológico' (CNPq) provided a doctoral fellowship to the first author.

\section{References}

Abbott R.T. 1974. American seashells. $2^{\text {nd }}$ ed. Van Nostrand Reinhold, New York.

Absalão R.S. 1989. Padrões distributivos e zoogeografia dos moluscos da plataforma continental brasileira. Parte III. Comissão Oceanográfica Espírito Santo I. Memórias do Instituto Oswaldo Cruz 84: 1-6. https://doi.org/10.1590/S0074-02761989000800006

Absalão R.S. \& Pimenta A.D. 2005. Moluscos marinhos da APA do Arquipélago de Santana, Macaé, RJ. Editora Ciência Moderna, Rio de Janeiro.

Absalão R.S., Caetano C.H.S. \& Fortes R.R. 2006. Filo Mollusca. In: Lavrado H.P. \& Ignacio B.L (eds) Biodiversidade bentônica da região central da Zona Econômica Exclusiva Brasileira: 211-260. Museu Nacional, Rio de Janeiro.

Adams C.B. 1839. Observations on some species of the marine shells of Massachusetts, with descriptions of five new species. Boston Journal of Natural History 2: 262-288.

Adams C.B. 1850. Descriptions of supposed new species of marine shells which inhabit Jamaica. Contributions to Conchology 7: 109-123. 
Adams A. 1854. Descriptions of new species of Eulima, Triphoris, etc., from the collection of Hugh Cuming, esq. Proceedings of the Zoological Society of London 19: 276-279.

https://doi.org/10.1111/j.1096-3642.1851.tb01178.x

Agudo-PadrónA.I. 2015. Inventario sistemático revisado y actualizado de los moluscos marinos ocurrentes en el Estado de Santa Catarina, Brasil. Revista Brasileira de Gestão Ambiental e Sustentabilidade 2: 59-75. https://doi.org/10.21438/rbgas.020206

Aguirre M.L. 1993. Type specimens of Quaternary marine gastropods from Argentina. Ameghiniana 30: $23-38$.

Albano P.G. \& Bakker P.A.J. 2016. Annotated catalogue of the types of Triphoridae (Mollusca, Gastropoda) in the Museum für Naturkunde, Berlin, with lectotype designations. Zoosystematics and Evolution 92: 33-78. https://doi.org/10.3897/zse.92.5936

Albano P.G., Sabelli B. \& Bouchet P. 2011. The challenge of small and rare species in marine biodiversity surveys: microgastropod diversity in a complex tropical coastal environment. Biodiversity and Conservation 20: 3223-3237. https://doi.org/10.1007/s10531-011-0117-x

Albano P.G., Bakker P.A.J. \& Sabelli B. 2019. Annotated catalogue of the types of Triphoridae (Mollusca, Gastropoda) in the Natural History Museum of the United Kingdom, London. Zoosystematics and Evolution 95: 161-308. https://doi.org/10.3897/zse.95.32803

Andrade B.G. 2017. Revisão taxonômica das famílias Epitoniidae e Nystiellidae (Mollusca, Gastropoda, Epitonioidea) nas provincias tropical e temperada do Atlântico Sudoeste. PhD thesis, UFRJ, Museu Nacional do Rio de Janeiro, Rio de Janeiro.

Ardovini R. \& Cossignani T. 2004. West African Seashells. L'Informatore Piceno, Ancona.

Barros J.C.N., Santos F.N., Santos M.C.F. \& Cabral E. 2002. Moluscos dragados pelo navio oceanográfico "Victor Hensen", ao largo do Arquipélago de Fernando de Noronha, Nordeste do Brasil. Boletim TécnicoCientífico do CEPENE 10: 27-37.

Barroso C.X., Lotufo T.M.C. \& Matthews-Cascon H. 2016. Biogeography of Brazilian prosobranch gastropods and their Atlantic relationships. Journal of Biogeography 43: 2477-2488.

https://doi.org/10.1111/jbi.12821

Bartsch P. 1907. The West American mollusks of the genus Triphoris. Proceedings of the United States National Museum 33: 249-262.

Bhaud M. 1998. The spreading potential of polychaete larvae does not predict adult distributions; consequences for conditions of recruitment. Developments in Hydrobiology 132: 35-47.

https://doi.org/10.1023/A:1017073409259

Bouchet P. 1985. Les Triphoridae de Méditerranée et du proche Atlantique (Mollusca, Gastropoda). Lavori de la Società Italiana di Malacologia 21: 5-58.

Bouchet P. \& Strong E. 2010. Historical name-bearing types in marine molluscs: an impediment to biodiversity studies? In: Polaszek A. (ed.) The Linnaean Ark - Systema Naturae 250: 63-74. CRC Press, London.

Bouchet P. \& Warén A. 1994. Ontogenetic migration and dispersal of deep-sea gastropod larvae. In: Young C.M. \& Eckelbarger K.J. (eds) Reproduction, Larval Biology and Recruitment of the Deep-Sea Benthos: 98-117. Columbia University Press, New York.

Bouchet P., Lozouet P., Maestrati P. \& Héros V. 2002. Assessing the magnitude of species richness in tropical marine environments: exceptionally high numbers of molluscs at a New Caledonia site. Biological Journal of the Linnean Society 75: 421-436. https://doi.org/10.1046/j.1095-8312.2002.00052.x 
Boyko C.B. \& Cordeiro J.R. 2001. Catalog of Recent type specimens in the Division of Invertebrate Zoology, American Museum of Natural History. V. Mollusca, Part 2. Bulletin of the American Museum of Natural History 262: 1-158. https://doi.org/10.1206/0003-0090(2001)262<0001:CORTSI>2.0.CO;2

Carmona L., Lei B.R., Pola M., Gosliner T.M., Valdés A. \& Cervera J.L. 2014. Untangling the Spurilla neapolitana (Delle Chiaje, 1841) species complex: a review of the genus Spurilla Bergh, 1864 (Mollusca: Nudibranchia: Aeolidiidae). Zoological Journal of the Linnean Society 170: 132-154.

https://doi.org/10.1111/zoj12098

Cecalupo A. \& Perugia I. 2013. The Cerithiopsidae (Caenogastropoda: Triphoroidea) of Espiritu Santo -Vanuatu- (South Pacific Ocean). Published by the authors, Milano.

Cipriani R., Pauls S.M. \& Losada F. 1994. Observations on the egg-capsules of Cerithiopsis flavum (C.B. Adams, 1850) (Gastropoda: Cerithiopsidae) from Venezuela. Journal of Molluscan Studies 60: 200-203. https://doi.org/10.1093/mollus/60.2.200

Claremont M., Williams S.T., Barraclough T.G. \& Reid D.G. 2011. The geographic scale of speciation in a marine snail with high dispersal potential. Journal of Biogeography 38: 1016-1032.

https://doi.org/10.1111/j.1365-2699.2011.02482.x

Clench W.J. \& Turner R.D. 1950. The Western Atlantic marine mollusks described by C.B. Adams. Occasional Papers on Mollusks 1: 233-403.

Coelho-Filho P.A. 2004. Análise do macrobentos na plataforma continental externa e bancos oceânicos do Nordeste do Brasil no âmbito do programa REVIZEE. Universidade Federal de Pernambuco, Recife. https://doi.org/10.5914/tropocean.v32i2.8026

Collin R. 2004. Development of Cerithiopsis gemmulosum (Gastropoda: Cerithiopsidae) from Bocas del Toro, Panama. Caribbean Journal of Science 40: 192-197.

Collin R. 2012. Nontraditional life-history choices: what can "intermediates" tell us about evolutionary transitions between modes of invertebrate development? Integrative and Comparative Biology 52: 128137. https://doi.org/10.1093/icb/ics065

Collin R., Chaparro O.R., Winkler F. \& Véliz D. 2007. Molecular phylogenetic and embryological evidence that feeding larvae have been reacquired in a marine gastropod. The Biological Bulletin 212: 83-92. https://doi.org/10.2307/25066586

Cooley N.R. 1978. An inventory of the estuarine fauna in the vicinity of Pensacola, Florida. Florida Marine Research Publications 31: 1-119.

Cruz F.V. \& Gándara C.G. 2006. Lista actualizada de los gasterópodos de la planicie del Arrecife Lobos, Veracruz, México. Revista UDO Agrícola 6: 128-137.

Daccarett E.Y. \& Bossio V.S. 2011. Colombian Seashells from the Caribbean Sea. L'Informatore Piceno, Ancona.

Dall W.H. 1892. Tertiary mollusks of Florida - Part II. Transactions of the Wagner Free Institute of Science of Philadelphia 3: 201-473.

Dall W.H. 1889. Reports on the results of dredging, under the supervision of Alexander Agassiz, in the Gulf of Mexico (1877-78) and in the Caribbean Sea (1879-80), by the U.S. Coast Survey steamer "Blake", Lieut.-Commander C. D. Sigsbee, U. S. N., and Commander J. R. Bartlett, U.S.N., Commanding. XXIX - Report on the Mollusca. Part II - Gastropoda and Scaphopoda. Bulletin of the Museum of Comparative Zoology 18: 1-492. 
Dall W.H. 1927. Small shells from dredgings off the southeast coast of the United States by the United States Fisheries Steamer "Albatross" in 1885 and 1886. Proceedings of the United States National Museum 70: 1-134. https://doi.org/10.5479/si.00963801.70-2667.1

Dall W.H. \& Simpson C.T. 1901. The Mollusca of Porto Rico. Bulletin of the United States Fish Comission 1: 351-524.

Dautzenberg P. 1900. Croisière du Yacht Chazalie dans l'Atlantique. Mollusques. Mémoires de la Société zoologique de France 13: 145-265.

Dautzenberg P. \& Fischer H. 1906. Mollusques provenant des dragages effectués à l'ouest de l'Afrique pendant les campagnes scientifiques de S.A.S. le Prince de Monaco. Résultats des campagnes scientifiques accomplies sur son yacht par Albert ler Prince Souverain de Monaco 32: 1-125.

De Jong K.M. \& Coomans H.E. 1988. Marine Gastropods from Curaçao, Aruba and Bonaire. E.J. Brill, Leiden.

deMaintenon M. 2004. Sexually dimorphic radular morphology in Euplica varians and E. versicolor (Neogastropoda: Columbellidae). Molluscan Research 24: 179-185. https://doi.org/10.1071/MR04011

Deshayes G.P. 1833. Mollusques. In: Bélanger C. (ed.) Voyage aux Indes-Orientales, par le nord de l'Europe, les provinces du Caucase, la Géorgie, l'Arménie et la Perse, suivi de détails topographiques, statistiques et autres sur le Pégou, les îles de Java, de Maurice et de Bourbon, sur le Cap-de-BonneEspérance et Sainte-Hélène, pendant les années 1825, 1826, 1827, 1828 et 1829. Arthus Bertrand, Paris.

Díaz J.M. 1994. La malacofauna de la zona costera de Santa Marta y Parque Nacional Natural Tayrona, Caribe Colombiano. Boletín de Investigaciones Marinas y Costeras 23: 15-43.

https://doi.org/10.25268/bimc.invemar.1994.23.0.387

Dietl G.P. \& Hendricks J.R. 2006. Crab scars reveal survival advantage of left-handed snails. Biology Letters 2: 439-442. https://doi.org/10.1098/rsbl.2006.0465

d'Orbigny A. 1852. Prodrome de paléontologie stratigraphique universelle des animaux mollusques \& rayonnés, faisant suite au Cours élémentaire de paléontologie et de géologie stratigraphiques. Volume 3. V. Masson, Paris.

Dowgiallo M.J. 2004. Patterns in Diversity and Distribution of Benthic Molluscs along a Depth Gradient in the Bahamas. $\mathrm{PhD}$ thesis, University of Maryland, College Park.

Ekdale A.A. 1974. Marine molluscs from shallow-water environments (0 to 60 meters) off the Northeast Yucatan coast, Mexico. Bulletin of Marine Science 24: 638-668.

Ellingson R.A. \& Krug P.J. 2016. Reduced genetic diversity and increased reproductive isolation follow population-level loss of larval dispersal in a marine gastropod. Evolution 70: 18-37. https://doi.org/10.1111/evo.12830

Espinosa J. 2001. Descripción de una nueva especie de Triphora (s. 1.) Blainville, 1828. In: Espinosa J. \& Ortea J. Moluscos del Mar Caribe de Costa Rica: desde Cahuita hasta Gandoca. Avicennia 4: 1-77.

Espinosa J. \& Ortea J. 2001. Moluscos del Mar Caribe de Costa Rica: desde Cahuita hasta Gandoca. Avicennia 4: 1-77.

Espinosa J., Ortea J., Fernández-Garcés R. \& Moro L. 2007. Adiciones a la fauna de moluscos marinos de la península de Guanahacabibes (I), con la descripción de nuevas espécies. Avicennia 19: 63-88.

Espinosa J., Ortea J., Sánchez R. \& Gutiérrez J. 2012. Moluscos marinos Reserva de la Biosfera de la Península de Guanahacabibes. Instituto de Oceanología, La Habana. 
Faber M.J. \& Moolenbeek R.G. 1991. Two new shallow water triphorids and a new name in Metaxia from Florida and the West Indies. Apex 6: 81-85.

Fedosov A.E. \& Puillandre N. 2012. Phylogeny and taxonomy of the Kermia-Pseudodaphnella (Mollusca: Gastropoda: Raphitomidae) genus complex: a remarkable radiation via diversification of larval development. Systematics and Biodiversity 10: 447-477. https://doi.org/10.1080/14772000.2012.753137

Fernandes F. \& Rolán E. 1988. A família Triphoridae (Mollusca: Gastropoda) no Arquipélago de Cabo Verde. Publicações Ocasionais da Sociedade Portuguesa de Malacologia 11: 17-32.

Fernandes F. \& Rolán E. 1993. Moluscos marinos de São Tomé y Principe: actualización bibliográfica y nuevas aportaciones. Iberus 11: 31-47.

Fernandes F. \& Rolán E. 1994. Check-list of the amphiatlantic Mollusca based on a revision of the literature. Reseñas Malacológicas 8: 3-36.

Fernandes M.R. 2014. Levantamento taxonômico de Triphorinae (Gastropoda, Triphoridae), exceto gênero Inella, da plataforma continental da Bacia de Campos, Sudeste do Brasil. MSc thesis, UFRJ, Museu Nacional do Rio de Janeiro, Rio de Janeiro.

Fernandes M.R. \& Araya J.F. 2019. New species and records of Triphoroidea (Gastropoda) from Chile. The Nautilus 133: 1-13.

Fernandes M.R. \& Pimenta A.D. 2011. Taxonomic review of Metaxia (Gastropoda: Triphoridae) from Brazil, with description of a new species. Zoologia 28: 819-830.

https://doi.org/10.1590/S1984-46702011000600016

Fernandes M.R. \& Pimenta A.D. 2014. Two species of the genus Strobiligera (Caenogastropoda: Triphoridae) with a multispiral protoconch in Southeastern Brazil. American Malacological Bulletin 32: 165-172. https://doi.org/10.4003/006.032.0207

Fernandes M.R. \& Pimenta A.D. 2015. Fivenew species and two records of Triphorinae (Caenogastropoda, Triphoridae) from Brazil. Zootaxa 4012: 493-513. https://doi.org/10.11646/zootaxa.4012.3.5

Fernandes M.R. \& Pimenta A.D. 2017a. Synopsis of the deep-sea groups of Triphoroidea (Gastropoda). Journal of Natural History 51: 853-865. https://doi.org/10.1080/00222933.2017.1293181

Fernandes M.R. \& Pimenta A.D. 2017b. A study of triphorid larvae and post-larvae at the Campos Basin deep-sea floor, southeastern Brazil (Gastropoda: Triphoroidea). Journal of Natural History 51: 867-881. https://doi.org/10.1080/00222933.2017.1293178

Fernandes M.R. \& Pimenta A.D. 2019a. Basic anatomy of species of Triphoridae (Gastropoda, Triphoroidea) from Brazil. European Journal of Taxonomy 517: 1-60.

https://doi.org/10.5852/ejt.2019.517

Fernandes M.R. \& Pimenta A.D. 2019b. Taxonomic review of Inella and Strobiligera (Gastropoda: Triphoridae) from Brazil. Zootaxa 4613: 1-52. https://doi.org/10.11646/zootaxa.4613.1.1

Fernandes M.R. \& Segadilha J.L. 2019. Shells of Triphoroidea (Gastropoda) occupied by crustaceans in the western Atlantic. Journal of Natural History 53: 127-139.

https://doi.org/10.1080/00222933.2019.1582816

Fernandes M.R., Pimenta A.D. \& Leal J.H. 2013. Taxonomic review of Triphorinae (Gastropoda: Triphoridae) from the Vitória-Trindade Seamount Chain, southeastern Brazil. The Nautilus 127: 1-18.

Fernandes M.R., Garofalo R. \& Pimenta A.D. 2015. New species and records of Newtoniellinae (Caenogastropoda, Newtoniellidae) from Brazil. Journal of the Marine Biological Association of the United Kingdom 95: 791-804. https://doi.org/10.1017/S0025315414001933 
Figueiras A. \& Sicardi O.E. 1972. Catálogo de los moluscos marinos del Uruguay. Parte VI. Comunicaciones de la Sociedad Malacológica del Uruguay 3: 101-127.

Forcelli D. \& Narosky T. 2015. Uruguayan Seashells. Vázquez Mazzini, Buenos Aires.

Francini-Filho R., Asp N.E., Siegle E., Hocevar J., Lowyck K., D’Avila N., Vasconcelos A.A., Baitelo R., Rezende C.E., Omachi C.Y., Thompson C.C. \& Thompson F.L. 2018. Perspectives on the Great Amazon Reef: Extension, Biodiversity, and Threats. Frontiers in Marine Science 5. https://doi.org/10.3389/fmars.2018.00142

Fujioka Y. 1982. On the secondary sexual characters found in the dimorphic radula of Drupella (Gastropoda: Muricidae) with reference to its taxonomic revision. Venus 40: 203-223.

Garcia E.F. \& Lee H.G. 2002. Report on molluscan species found in the offshore waters of Louisiana, including many extensions of known range and un-named species. American Conchologist 30: 10-13.

Garcia E.F. \& Lee H.G. 2011. Report on Molluscan Species found in the Offshore Waters of Louisiana, Including Many Extensions of Known Range and Un-named Species.

Available from http://www.jaxshells.org/efg1030.htm [accessed 25 Mar. 2020].

García Y.L.D. 2016. Nuevos registros de moluscos marinos en Santiago de Cuba, Cuba. Revista Cubana de Ciencias Biológicas 5: 102-112.

García Y.L.D. \& Capote A.J. 2012. Moluscos marinos del sector Bahía de Puerto Padre - Bahía de Nipe, Cuba. Amici Molluscarum 20: 17-28.

García Y.L.D. \& Capote A.J. 2013. Lista y distribución de los moluscos marinos de Santiago de Cuba, costa suroriental de Cuba. Amici Molluscarum 21: 23-38.

Gardner J. 1948. Mollusca from the Miocene and Lower Pliocene of Virginia and North Carolina. Part 2. Scaphopoda and Gastropoda. Geological Survey Professional Paper 199-B: 179-310. https://doi.org/10.3133/pp199B

Gomes R.G., Costa P.M.S., Monteiro J.C., Coelho A.C.S. \& Salgado N.C. 2006. Moluscos das ilhas oceânicas brasileiras. In: Alves R.J.V. \& Castro J.W.A. (eds) Ilhas oceânicas brasileiras: da pesquisa ao manejo: 180-198. Ministério do Meio Ambiente, Brasília.

Gracia A., Cruz N., Borrero G., Báez D.P. \& Santodomingo N. 2013. Invertebrados marinos asociados con las plataformas de gas en La Guajira (Caribe Colombiano). Boletín de Investigaciones Marinas y Costeras 42: 361-386. https://doi.org/10.25268/bimc.invemar.2013.42.2.56

Gutiérrez-Salcedo J.M., Aguilar-Pérez M.I., Bermúdez A., Campos N.H. \& Navas G.R. 2007. Estructura de la macrofauna de invertebrados presente en los nidos del pez Malacanthus plumieri (Bloch, 1786) (Perciformes: Malacanthidae) en la Bahía de Nenguange, Parque Nacional Natural Tayrona, mar Caribe colombiano. Caldasia 29: 309-328.

Healy J.M. 1990. Systematic importance of spermatozeugmata in triphorid and cerithiopsid gastropods (Caenogastropoda: Triphoroidea). Journal of Molluscan Studies 56: 115-118.

https://doi.org/10.1093/mollus/56.1.115

Hess D.F. \& Abbott T. 1994. Marine molluscs of the Cayman Islands. In: Brunt M.A. \& Davies J.E. (eds) The Cayman Islands: Natural History and Biogeography: 139-189. Springer, Dordrecht. https://doi.org/10.1007/978-94-011-0904-8_9

Hewitt S.J. \& van Leeuwen S. 2017. Marine molluscs of St. Eustatius, eastern Caribbean: results of the Statia Marine Biodiversity Expedition 2015. Vita Malacologica 16: 44-80.

Houbrick R.S. 1968. A survey of the littoral marine mollusks of the Caribbean coast of Costa Rica. The Veliger 11: 4-23. 
ICZN 1999. International Code of Zoological Nomenclature. $4^{\mathrm{a}}$ ed. The International Trust for Zoological Nomenclature.

ICZN 2017. Declaration 45 - addition of recommendations to article 73 and of the term "specimen, preserved" to the glossary. The Bulletin of Zoological Nomenclature 73: 96-98.

https://doi.org/10.21805/bzn.v73i2.a2

Jablonski D. \& Lutz R.A. 1983. Larval ecology of marine benthic invertebrates: paleobiological implications. Biological Reviews 58: 21-89. https://doi.org/10.1111/j.1469-185X.1983.tb00380.x

Jensen R.H. \& Pearce T.A. 2009. Marine Mollusks of Bermuda-Checklist and Bibliography. Delaware Museum of Natural History, Wilmington.

Jousseaume F. 1884. Monographie des Triforidae. Bulletin de la Société malacologique de France 1: $217-270$.

Knott K.E. \& McHugh D. 2012. Introduction to symposium: poecilogony - a window on larval evolutionary transitions in marine invertebrates. Integrative and Comparative Biology 52: 120-127. https://doi.org/10.1093/icb/ics037

Kobluk D.R. \& Lysenko M.A. 1986. Reef-dwelling molluscs in open framework cavities, Bonaire N.A., and their potential for preservation in a fossil reef. Bulletin of Marine Science 39: 657-672.

Kosuge S. 1966. The family Triphoridae and its systematic position. Malacologia 4: 297-324.

Krell F. \& Marshall S.A. 2017. New species described from photographs: yes? No? Sometimes? A fierce debate and a new declaration of the ICZN. Insect Systematics and Diversity 1: 3-19.

https://doi.org/10.1093/isd/ixx004

Krug P.J. \& Zimmer R.K. 2004. Developmental dimorphism: consequences for larval behavior and dispersal potential in a marine gastropod. The Biological Bulletin 207: 233-246.

https://doi.org/10.2307/1543212

Lamy D. \& Pointier J.P. 2018. Marine and Freshwater Molluscs of the French Caribbean. PLB Editions, Guadeloupe.

Lange-de-Morretes F. 1949. Ensaio de catálogo dos moluscos do Brasil. Arquivos do Museu Paranaense 7: $1-76$.

Laseron C.F. 1958. The family Triphoridae (Mollusca) from northern Australia; also Triphoridae from Christmas Island (Indian Ocean). Australian Journal of Marine and Freshwater Research 9: 569-658. https://doi.org/10.1071/MF9580569

Lea H.C. 1843. Description of some new fossil shells, from the Tertiary of Petersburg, Virginia. Transactions of the American Philosophical Society 9: 229-274.

Leal J.H. 1991. Marine Prosobranch Gastropods from Oceanic Islands off Brazil: Species Composition and Biogeography. Universal Book Services, Oegstgeest.

Leal J.H. 2000. Endemism and modes of development of marine prosobranch gastropods (Mollusca) from oceanic islands off Brazil. Arquipelago - Life and Marine Sciences suppl. 2: 79-87.

Lebour M.V. 1933. The life-histories of Cerithiopsis tubercularis (Montagu), C. barleei (Jeffreys) and Triphora perversa (L.). Journal of the Marine Biological Association of the United Kingdom 18: 491498. https://doi.org/10.1017/S0025315400043824

Lee H.G. 2009. Marine Shells of Northeast Florida. Shell Club, Jacksonville. 
Longo P.A.S., Fernandes M.C., Leite F.P.P. \& Passos F.D. 2014. Gastropoda (Mollusca) associated to Sargassum sp. beds in São Sebastião Channel São Paulo, Brazil. Biota Neotropica 14: 1-10. https://doi.org/10.1590/1676-06032014011514

Malaquias M.A.E. \& Reid D.G. 2009. Tethyan vicariance, relictualism and speciation: evidence from a global molecular phylogeny of the opisthobranch genus Bulla. Journal of Biogeography 36: 1760-1777. https://doi.org/10.1111/j.1365-2699.2009.02118.x

Marcus Er. \& Marcus Ev. 1963. Mesogastropoden von der Küste São Paulos. Abhandlungen der Mathematisch-Naturwissenschaftlichen Klasse 1: 1-105.

Marshall B.A. 1977. The dextral triforid genus Metaxia (Mollusca: Gastropoda) in the south-west Pacific. New Zealand Journal of Zoology 4: 111-117. https://doi.org/10.1080/03014223.1977.9517944

Marshall B.A. 1983. A revision of the recent Triphoridae of Southern Australia (Mollusca: Gastropoda). Records of the Australian Museum suppl. 2: 1-119. https://doi.org/10.3853/j.0812-7387.2.1983.102

Martínez S., Rojas A., Ubilla M., Verde M., Perea D. \& Piñeiro G. 2006. Molluscan assemblages from the marine Holocene of Uruguay: composition, geochronology, and palaeoenvironmental signals. Ameghiniana 43: 385-398.

Martínez S., del Río C.J. \& Rojas A. 2013. Quaternary mollusks. In: Martínez S., del Río C.J. \& Rojas A. (eds) Biogeography of the Quaternary Molluscs of the Southwestern Atlantic Ocean: 17-32. Springer, Dordrecht. https://doi.org/10.1007/978-94-007-6055-4_5

Matthews-Cascon H., Alencar H.A.P., Rabay S.G. \& Mota R.M.S. 2005. Sexual dimorphism in the radula of Pisania pusio (Linnaeus, 1758) (Mollusca, Gastropoda, Buccinidae). Thalassas 21: 29-33.

Maury C.J. 1988. Fósseis Terciários do Brasil com descrição de novas formas cretáceas. $2^{\text {nd }}$ ed. Coleção Mossoroense.

McClain C.R. \& Crouse J. 2006. Influence of ecological role on bathymetric patterns of deep-sea species: size clines in parasitic gastropods. Marine Ecology Progress Series 320: 161-167.

https://doi.org/10.3354/meps320161

McClain C.R., Boyer A.G. \& Rosenberg G. 2006. The island rule and the evolution of body size in the deep sea. Journal of Biogeography 33: 1578-1584. https://doi.org/10.1111/j.1365-2699.2006.01545.x

McClain C.R., Gullett T., Jackson-Ricketts J. \& Unmack P.J. 2012. Increased energy promotes sizebased niche availability in marine mollusks. Evolution 66: 2204-2215.

https://doi.org/10.1111/j.1558-5646.2012.01580.x

McDonald K.A., Collin R. \& Lesoway M.P. 2014. Poecilogony in the caenogastropod Calyptraea lichen (Mollusca: Gastropoda). Invertebrate Biology 133: 213-220. https://doi.org/10.1111/ivb.12057

Merlano J.M.D. \& Hegedus M.P. 1994. Moluscos del Caribe Colombiano. Colciencias, Fundación Natura, Invemar, Santa Fé de Bogotá.

Miller W. 1989. Checklist of megafossils from the James City Formation (Lower Pleistocene) at Johnson Point, Craven County, North Carolina. Tulane Studies in Geology and Paleontology 22: 93-100.

Miloslavich P., Klein E., Díaz J.M., Hernández C.E., Bigatti G., Campos L., Artigas F., Castillo J., Penchaszadeh P.E., Neill P.E., Carranza A., Retana M.V., Astarloa J.M.D., Lewis M., Yorio P., Piriz M.L., Rodríguez D., Yoneshigue-Valentin Y., Gamboa L. \& Martín A. 2011. Marine biodiversity in the Atlantic and Pacific coasts of South America: knowledge and gaps. PLoS ONE 6: e14631.

https://doi.org/10.1371/journal.pone.0014631

MolluscaBase. 2019. Available from http://www.molluscabase.org [accessed Mar. 2019]. 
Montagna P. 2006. A Multivariate Statistical Analysis of Relationships between Freshwater Inflows and Mollusk Distibutions in Tidal Rivers in Southwest Florida. Harte Research Institute for Gulf of Mexico Studies, Texas A\&M University, Corpus Christi.

Moolenbeek R.G. \& Faber M.J. 1989. Two new Triphora species from the West Indies (Gastropoda; Triphoridae). Basteria 53: 77-80.

Moura R.L., Amado-Filho G.M., Moraes F.C., Brasileiro P.S., Salomon P.S., Mahiques M.M., Bastos A.C., Almeida M.G., Silva J.M., Araujo B.F., Brito F.P., Rangel T.P., Oliveira B.C.V., Bahia R.G., Paranhos R.P., Dias R.J.S., Siegle E., Figueiredo A.G., Pereira R.C., Leal C.V., Hajdu E., Asp N.E., Gregoracci G.B., Neumann-Leitão S., Yager P.L., Francini-Filho R.B., Fróes A., Campeão M., Silva B.S., Moreira A.P.B., Oliveira L., Soares A.C., Araujo L., Oliveira N.L., Teixeira J.B., Valle R.A.B., Thompson C.C., Rezende C.E. \& Thompson F.L. 2016. An extensive reef system at the Amazon river mouth. Science Advances 2: 1-11. https://doi.org/10.1126/sciadv.1501252

Mutlu E. 2004. Sexual dimorphisms in radula of Conomurex persicus (Gastropoda: Strombidae) in the Mediterranean Sea. Marine Biology 145: 693-698. https://doi.org/10.1007/s00227-004-1370-2

Nowell-Usticke G.W. 1969. A Supplementary Listing of New Shells (Illustrated). To be Added to the Check List of the Marine Shells of St. Croix. Published by the author.

Nützel A. 1998. Über die Stammesgeschichte der Ptenoglossa (Gastropoda). Berliner Geowissenschaftliche Abhandlungen E26: 1-229.

Nützel A. 2014. Larval ecology and morphology in fossil gastropods. Palaeontology 57: 479-503. https://doi.org/10.1111/pala.12104

Odé H. 1989. Distribution and records of the marine Mollusca in the northwest Gulf of Mexico (a continuing monograph). Texas Conchologist 25:104-120.

Oliveira P.S., Martins-Silva M.J., de Barros J.C.N., Swoboda I., Francisco J.A., Schneider M., Batista J.C.L., de Aquino P.P.U., Vianna G. \& Coutinho M.F. 2009. Malacofauna. In: Viana D.L., Hazin F.H.V. \& de Souza M.A.C. (eds) O Arquipélago de São Pedro e São Paulo: 10 anos de estação científica. SECIRM, Brasília.

Olsson A.A. 1916. New Miocene fossils. Bulletins of American Paleontology 5: 1-32.

Olsson A.A. \& Harbison A. 1953. Pliocene Mollusca of southern Florida, with special reference to those from North Saint Petersburg. Academy of Natural Sciences of Philadelphia, Monograph 8: 1-361.

Olsson A.A. \& McGinty T.L. 1958. Recent marine mollusks from the Caribbean coast of Panama with the description of some new genera and species. Bulletins of American Paleontology 39: 1-58.

Özdikmen H. 2013. Substitute names for three preoccupied generic names in Gastropoda. Munis Entomology and Zoology 8: 252-256.

Padula V., Bahia J., Stöger I., Camacho-García Y., Malaquias M.A.E., Cervera J.L. \& Schrödl M. 2016. A test of color-based taxonomy in nudibranchs: molecular phylogeny and species delimitation of the Felimida clenchi (Mollusca: Chromodorididae) species complex. Molecular Phylogenetics and Evolution 103: 215-229. https://doi.org/10.1016/j.ympev.2016.07.019

Paranaguá M.N., Neumann-Leitão S., Melo R.L.S., Coelho P.A., Vasconcelos Filho A.L. \& Oliveira A.M.E. 1999. Management in northeastern Brazil: faunal biodiversity. Transactions on Ecology and the Environment 27: 57-67.

Parker R.H. \& Curray J.R. 1956. Fauna and bathymetry of banks on continental shelf, northwest Gulf of Mexico. Bulletin of the American Association of Petroleum Geologists 40: 2428-2439. https://doi.org/10.1306/5CEAE59B-16BB-11D7-8645000102C1865D 
Pechenik J.A. 2006. Larval experience and latent effects - metamorphosis is not a new beginning. Integrative and Comparative Biology 46: 323-333. https://doi.org/10.1093/icb/icj028

Pelseneer P. 1926. Note d'embryologie malacologique. Ponte et développement de Cypraea europea, Trifora perversa et Lucina lactea. Bulletin biologique de la France et de la Belgique 60: 88-112.

Peñas A. \& Rolán E. 2010. Deep water Pyramidelloidea of the Tropical South Pacific: Turbonilla and related genera. Mémoires du Muséum national d'histoire naturelle 200: 13-436.

Perry L.M. \& Schwengel J.S. 1955. Marine Shells of the Western Coast of Florida. Paleontological Research Institution, Ithaca.

Petuch E.J. 2013. Biogeography and Biodiversity of Western Atlantic Mollusks. CRC Press, Boca Raton. https://doi.org/10.1201/b14798

Ponder W.F., Colgan D.J., Healy J.M., Nützel A., Simone L.R.L. \& Strong E.E. 2008. Caenogastropoda. In: W.F. Ponder \& D.R. Lindberg (eds) Phylogeny and Evolution of the Mollusca: 331-383. University of California Press, Berkeley, Los Angeles and London.

https://doi.org/10.1525/california/9780520250925.003.0013

Porta J. \& Porta N.S. 1960. El cuaternario marino de la isla de Tierrabomba (Bolívar). Boletín de Geología 4: 19-44.

Poulin R. 2011. The many roads to parasitism: a tale of convergence. Advances in Parasitology 74: 1-40. https://doi.org/10.1016/B978-0-12-385897-9.00001-X

Pyle R.L. 2001. Assessing undiscovered fish biodiversity on deep coral reefs using advanced selfcontained diving technology. Marine Technology Society Journal 34: 82-91.

https://doi.org/10.4031/MTSJ.34.4.11

Redfern C. 2001. Bahamian Seashells - a Thousand Species from Abaco, Bahamas. Bahamian Seashells Inc., Boca Raton.

Redfern C. 2013. Bahamian Seashells: 1161 Species from Abaco, Bahamas. Bahamian Seashells Inc., Boca Raton.

Reed J.K. \& Mikkelsen P.M. 1987. The molluscan community associated with the scleractinian coral Oculina varicosa. Bulletin of Marine Science 40: 99-131.

Reyes J.L., Flores-Sánchez A., Carruyo-Noguera J., Casler C.L., Narciso S., Nava M. \& Guerra-Gómez A. 2007. Moluscos gasterópodos y bivalvos de La Alta Guajira, Estado Zulia, Venezuela. Boletín del Centro de Investigaciones Biológicas 41: 376-393.

Rice W.H. \& Kornicker L.S. 1962. Mollusks of Alacran Reef, Campeche Bank, Mexico. Publications of the Institute of Marine Science 8: 366-403.

Rios E. 1970. Coastal Brazilian Seashells. Museu Oceanográfico do Rio Grande, Rio Grande.

Rios E. 1975. Brazilian Marine Mollusks Iconography. Museu Oceanográfico da FURG, Rio Grande.

Rios E. 1985. Seashells of Brazil. Museu Oceanográfico da FURG, Rio Grande.

Rios E. 1994. Seashells of Brazil. $2^{\text {nd }}$ ed. Museu Oceanográfico da FURG, Rio Grande.

Rios E. 2009. Compendium of Brazilian Seashells. Evangraf, Rio Grande.

Robertson R. 2007. Taxonomic occurrences of gastropod spermatozeugmata and non-stylommatophoran spermatophores updated. American Malacological Bulletin, 23: 11-16.

https://doi.org/10.4003/0740-2783-23.1.11 
Robinson D.G. \& Montoya M. 1987. Los moluscos marinos de la Costa Atlántica de Costa Rica. Revista de Biología Tropical 35: 375-400.

Rocha C.A., Franklin-Júnior W., Dantas N.P., Farias M.F. \& Oliveira A.M.E. 1997. Fauna e flora acompanhantes da pesca da lagosta no Nordeste do Brasil. Boletim Técnico-Cientifico do CEPENE 5: $11-22$.

Rolán E. 2005. Malacological Fauna from the Cape Verde Archipelago. ConchBooks, Hackenheim.

Rolán E. \& Cruz-Ábrego F.M. 1996. A new triphorid species (Gastropoda, Triphoridae) from Nichupté lagoon, Yucatán peninsula, Mexico. Iberus 13: 87-92.

Rolán E. \& Espinosa J. 1992. La família Cerithiopsidae H. Y. A. Adams, 1853 (Mollusca, Gastropoda), em la isla de Cuba. 2. El genero Horologica Laseron, 1956. Publicações ocasionais da Sociedade Portuguesa de Malacologia 16: 45-50.

Rolán E. \& Espinosa J. 1994. The family Triphoridae (Mollusca, Gastropoda) in Cuba. 3. The genus Isotriphora, with description of a new species. Basteria 58: 63-68.

Rolán E. \& Fernández-Garcés R. 1992. La famiglia Triphoridae (Mollusca: Gastropoda) em la isla de Cuba. 1: el género Metaxia Monterosato, 1884. Bollettino Malacologico 28: 169-176.

Rolán E. \& Fernández-Garcés R. 1993. The family Triphoridae (Mollusca, Gastropoda) in Cuba. 2. The genus Iniforis Jousseaume, 1884. Apex 8: 95-105.

Rolán E. \& Fernández-Garcés R. 1994. The family Triphoridae (Mollusca, Gastropoda) in Cuba. 4. The genera Monophorus, Nototriphora, Cosmotriphora and Cheirodonta, with the description of three new species. Apex 9: 17-27.

Rolán E. \& Fernández-Garcés R. 1995. The family Triphoridae (Mollusca, Gastropoda) in Cuba. 5. The genera Marshallora, Mesophora, Similiphora, Eutriphora, Latitriphora, Aclophora and other species without generic affiliation. Apex 10: 9-24.

Rolán E. \& Fernández-Garcés R. 2007. Caribbean Triphoridae (Gastropoda: Triphoroidea): list and colour ilustrations. Neptunea 6: 13-24.

Rolán E. \& Fernández-Garcés R. 2008. New data on the Caribbean Triphoridae (Caenogastropoda, Triphoroidea) with the description of 26 new species. Iberus 26: 81-170.

Rolán E. \& Fernández-Garcés R. 2009. Two new species of Iniforis (Gastropoda: Triphoridae) from the Caribbean. Novapex 10: 103-108.

Rolán E. \& Fernández-Garcés R. 2015. Triphorids of the Karubenthos Expedition to Guadeloupe Island. Gloria Maris 54: 46-54.

Rolán E. \& Luque A.A. 1999. Two new species of triphorids (Gastropoda, Triphoridae) from the Miskitos Archipelago, Nicaragua. Iberus 17: 107-113.

Rolán E. \& Redfern C. 1996. Variabilidad de la protoconcha de Metaxia rugulosa (C.B. Adams, 1850) (Gastropoda; Triphoridae). Noticiario de la Sociedad Española de Malacologia 26: 27-29.

Rosenberg G. 1997. Why do Shells have their Colors? Conchologists of America, Clute, TX.

Rosenberg G. 2009. Malacolog 4.1.1: A Database of Western Atlantic Marine Mollusca. Available from http://www.malacolog.org/ [accessed 25 Mar. 2020].

Rosenberg G., Moretzsohn F. \& Garcia E. 2009. Gastropoda (Mollusca) of the Gulf of Mexico. In: Felder D. \& Earle S. (eds) Gulf of Mexico Origin, Waters and Biota: Biodiversity: 579-699. Texas A\&M University Press, College Station. 
Russini V., Giannuzzi-Savelli R., Pusateri F., Prkic J., Fassio G., Modica M.V. \& Oliverio M. 2020. Candidate cases of poecilogony in Neogastropoda: implications for the systematics of the genus Raphitoma Bellardi, 1847. Invertebrate Systematics 34: 293-318. https://doi.org/10.1071/IS19039

Santos F.N., Caetano C.H.S., Absalão R.S. \& de Paula T.S. 2007. Mollusca de substrato não consolidado. In: Creed J.C., Pires D.O. \& Figueiredo M.A.O (eds) Biodiversidade marinha da Baía da Ilha Grande: 207-236. Ministério do Meio Ambiente, Brasília.

Scheltema R.S. 1971. Larval dispersal as a means of genetic exchange between geographically separated populations of shallow-water benthic marine gastropods. The Biological Bulletin 140: 284-322. https://doi.org/10.2307/1540075

Sevilla L.R., Vargas R. \& Cortés J. 2003. Biodiversidad marina de Costa Rica: gastrópodos (Mollusca: Gastropoda) de la costa Caribe. Revista de Biología Tropical 51: 305-399.

Shigemiya Y. 2003. Does the handedness of the pebble crab Eriphia smithii influence its attack success on two dextral snail species? Journal of Zoology 260: 259-265.

https://doi.org/10.1017/S095283690300373X

Simone L.R.L. 2006. A new Triphoridae from Canopus Bank, N.E. Brazil (Caenogastropoda). Strombus 13: $6-8$.

Simone L.R.L \& Mezzalira S. 1994. Fossil Molluscs of Brazil. Governo do Estado de São Paulo, Secretaria do Meio Ambiente, São Paulo.

Smith E.A. 1890. Report on the marine molluscan fauna of the island of St. Helena. Proceedings of the Zoological Society of London 1890: 247-317.

Solé-Cava A.M., Kelecom A. \& Kannengiesser G.J. 1981. Study of some sponges (Porifera, Demospongiae) from the infralitoral of Guarapari, Espírito Santo, Brazil. Iheringia 60: 125-150.

Spalding M.D., Fox H.E., Allen G.R., Davidson N., Ferdaña Z.A., Finlayson M., Halpern B.S., Jorge M.A., Lombana A., Lourie S.A., Martin K.D., McManus E., Molnar J., Recchia C.A. \& Robertson J. 2007. Marine ecoregions of the world: a bioregionalization of coastal and shelf areas. BioScience 57: 573-583. https://doi.org/10.1641/B570707

Treece G.D. 1980. Bathymetric records of marine shelled Mollusca from the Northeastern shelf and upper slope of Yucatan, Mexico. Bulletin of Marine Science 30: 552-570.

Tunnell J.W., Andrews J., Barrera N.C. \& Moretzsohn F. 2010. Encyclopedia of Texas Seashells Identification, Ecology, Distribution and History. Harte Research Institute for Gulf of Mexico Studies Series, College Station.

Valentine J.W., Roy K. \& Jablonski D. 2002. Carnivore/non-carnivore ratios in northeastern Pacific marine gastropods. Marine Ecology Progress Series 228: 153-163. https://doi.org/10.3354/meps228153

Vermeij G.J. 2012. Crucibles of creativity: the geographic origins of tropical molluscan innovations. Evolutionary Ecology 26: 357-373. https://doi.org/10.1007/s10682-010-9458-2

Vermeij G.J. 2015. Gastropod skeletal defences: land, freshwater, and sea compared. Vita Malacologica 13: $1-25$.

Verrill A.E. \& Bush K.J. 1900. Additions to the marine Mollusca of the Bermudas. Transactions of the Connecticut Academy of Arts and Sciences 10: 513-544.

Vokes H.E. \& Vokes E.H. 1983. Distribution of Shallow Water Marine Mollusca, Yucatan Peninsula, Mexico. Mesoamerican Ecology Institute, Middle American Research Institute, New Orleans.

Warén A. \& Bouchet P. 2001. Gastropoda and Monoplacophora from hydrothermal vents and seeps new taxa and records. The Veliger 44: 116-231. 
Warmke G.L. \& Abbott R.T. 1962. Caribbean Seashells. Dover Publications, New York.

Watling L., Guinotte J., Clark M.R. \& Smith C.R. 2013. A proposed biogeography of the deep ocean floor. Progress in Oceanography 111: 91-112. https://doi.org/10.1016/j.pocean.2012.11.003

Wells F.E. 1998. Superfamily Triphoroidea. In: Beesley P.L., Ross G.J.B. \& Wells A. (eds) Mollusca: the Southern Synthesis, Vol. 5, Part B: 808-811. CSIRO Publishing, Melbourne.

Williams S.T., Ito S., Wakamatsu K., Goral T., Edwards N.P., Wogelius R.A., Henkel T., de Oliveira L.F.C., Maia L.F., Strekopytov S., Jeffries T., Speiser D.I. \& Marsden J.T. 2016. Identification of shell colour pigments in marine snails Clanculus pharaonius and C. margaritarius (Trochoidea; Gastropoda). PLoS ONE 11: e0156664. https://doi.org/10.1371/journal.pone.0156664

Young C.M., He R., Emlet R.B., Li Y., Qian H., Arellano S.M., Van Gaest A., Bennett K.C., Wolf M., Smart T.I. \& Rice M.E. 2012. Dispersal of deep-sea larvae from the intra-American seas: simulations of trajectories using ocean models. Integrative and Comparative Biology 52: 483-496.

https://doi.org/10.1093/icb/ics090

Zamudio K.R., Kellner A., Serejo C., Britto M.R., Castro C.B., Buckup P.A., Pires D.O., Couri M., Kury A.B., Cardoso I.A., Monné M.L., Pombal Jr J., Patiu C.M., Padula V., Pimenta A.D., Ventura C.R.R., Hajdu E., Zanol J., Bruna E.M., Fitzpatrick J. \& Rocha L.A. 2018. Lack of science support fails Brazil. Science 361: 1322-1323. https://doi.org/10.1126/science.aav3296

Zhang D.Y. 2011. Antiguan Shallow-water Seashells - a Collection with 18 Years Study and Research of Shoreline Shells from Antigua, West Indies. MdM Publishing, Wellington.

Manuscript received: 4 June 2019

Manuscript accepted: 9 January 2020

Published on: 12 June 2020

Topic editor: Rudy Jocqué

Section editor: Thierry Backeljau

Desk editor: Kristiaan Hoedemakers

Printed versions of all papers are also deposited in the libraries of the institutes that are members of the EJT consortium: Muséum national d'histoire naturelle, Paris, France; Meise Botanic Garden, Belgium; Royal Museum for Central Africa, Tervuren, Belgium; Royal Belgian Institute of Natural Sciences, Brussels, Belgium; Natural History Museum of Denmark, Copenhagen, Denmark; Naturalis Biodiversity Center, Leiden, the Netherlands; Museo Nacional de Ciencias Naturales-CSIC, Madrid, Spain; Real Jardín Botánico de Madrid CSIC, Spain; Zoological Research Museum Alexander Koenig, Bonn, Germany; National Museum, Prague, Czech Republic. 


\section{Appendix}

The following is a list of ordinary material examined and not published elsewhere. Some species which were not fully illustrated in previous works from Brazil are also figured herein.

\section{Metaxia excelsa Faber \& Moolenbeek, 1991}

Cerithium exile C.B. Adams, 1850 non Eichholtz, 1829: 120.

Metaxia excelsa Faber \& Moolenbeek, 1991: 83.

Cerithium exile - Clench \& Turner 1950: 279, pl. 38 fig. 8 .

Cerithiopsis exile - Parker \& Curray 1956: 2433. - Robinson \& Montoya 1987: 383.

Cerithiopsis exilis - Rios 1970: 44; 1975: 48, pl. 13 fig. 175; 1985: 50, pl. 19 fig. 223.

Metaxia exilis - De Jong \& Coomans 1988: 51. - Leal 1991: 124, pl. 17 figs e-f. — Rios 1994: 95, pl. 31 fig. 381; 2009: 175, fig. 420. — Absalão et al. 2006: 238. — Gomes et al. 2006: 187.

Metaxia excelsa - Rolán \& Fernández-Garcés 1992: 172, figs 1, 7; 2007: pl. IV fig. 68; 2015: 54, pl. 4 fig. f. — Redfern 2001: 69, pl. 34 fig. 291; 2013: 131, fig. 375. — Sevilla et al. 2003: 343. — Lee 2009: 90. — Fernandes \& Pimenta 2011: 820, figs 1-6; 2019a: 7, figs 2a, 3. — Zhang 2011: 103, fig. 309. - Espinosa et al. 2012: 258. — García 2016: 106 — Lamy \& Pointier 2018: 287, pl. 92 fig. 2.

\section{Material examined}

BONAIRE • 1 spec.; Nukove; depth 21 m; 14 Feb. 1998; MNRJ 32361*.

BRAZIL - North Brazil • 1 spec.; REVIZEE-Norte III st. 211A; UFMA*. - Rio Grande do Norte • 9 specs; BPot 1-MR32; MNRJ 32057* • 3 specs; BPot 1-MR41; MNRJ 31454* • 2 specs; BPot 1-MR42; MNRJ 31459* • 7 specs; BPot 1-MR43; MNRJ 31456* • 4 specs; BPot 2-MR42; MNRJ 31455* • 9 specs; BPot 2-MR44; MNRJ 31457* • 7 specs; BPot 2-MR45; MNRJ 31458*. - Sergipe • 1 spec.; Petro/UFS st. E6-A2; UFS. - Bahia - 7 specs; Baía de Todos os Santos; Jun. 1997; MNRJ 34425* • 1 spec.; 1329'41" S, 3849'07" W; Mar. 2006; MNRJ 32606* • 6 specs; Ilhéus; MNRJ 32375* • 8 specs; Ilhéus; MNRJ 32972*. - Vitória-Trindade Chain • 1 spec.; REVIZEE-Central C1-C61; MORG 40317. - Espírito Santo • 1 spec.; 19²5'34" S, 39²2'16" W; depth 42 m; Oct. 2003; MNRJ 19317* • 1 spec.; $19^{\circ} 26^{\prime} 19^{\prime \prime}$ S, 39¹5'17" W; depth 53 m; Oct. 2003; MNRJ 19043*.

Metaxia gongyloskymnus Fernandes \& Pimenta, 2011

Metaxia gongyloskymnus Fernandes \& Pimenta, 2011: 826, figs 25-31.

\section{Material examined}

BRAZIL - Rio de Janeiro • 1 spec.; $23^{\circ} 05^{\prime} \mathrm{S}, 40^{\circ} 58^{\prime} \mathrm{W}$; depth $100 \mathrm{~m}$; MNRJ $17225^{*} \bullet 4$ specs; $23^{\circ} 05^{\prime} \mathrm{S}$, $40^{\circ} 58^{\prime} \mathrm{W}$; depth $100 \mathrm{~m}$; MNRJ 26600* 2 specs; 2305' S, 40 58' W; depth $100 \mathrm{~m}$; MNRJ 33114* • 1 spec.; $23^{\circ} 05^{\prime} \mathrm{S}, 40^{\circ} 58^{\prime} \mathrm{W}$; depth $100 \mathrm{~m}$; MNRJ 35544*.

\section{Metaxia rugulosa (C.B. Adams, 1850)}

Cerithium rugulosum C.B. Adams, 1850: 121-122.

Cerithiopsis bermudensis Verrill \& Bush, 1900: 536, pl. 65 fig. 20. Synonymy uncertain.

Metaxia rugulata [sic] - Espinosa et al. 2012: 258.

Cerithium rugulosum - Clench \& Turner 1950: 339, pl. 38 fig. 17.

Cerithiopsis rugulosum - Olsson \& McGinty 1958: 13. — Houbrick 1968: 14. — Abbott 1974: 109. — Vokes \& Vokes 1983: 18, pl. 27 fig. 8. — Robinson \& Montoya 1987: 383. — Díaz 1994: 33. 
Metaxia rugulosa - Marshall 1977: 113. — Reed \& Mikkelsen 1987: 108. — De Jong \& Coomans 1988: 51. — Rolán \& Fernández-Garcés 1992: 170, 172, figs 2, 9; 2007: pl. IV figs 15-18. — Rolán \& Redfern 1996. — Redfern 2001: 69-70, pl. 34 fig. 292, pl. 109 fig. 292; 2013: 131, fig. 376. — Sevilla et al. 2003: 343. — Lee 2009: 90. — Tunnell et al. 2010: 206. — Fernandes \& Pimenta 2011: 822, figs 12-19; 2019a: 10, figs 2b, 4. — Daccarett \& Bossio 2011: 91, fig. 415. — Zhang 2011:101, fig.308.

\section{Material examined}

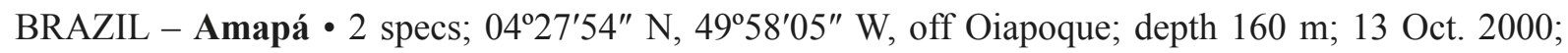
MNRJ 26610*. - Maranhão • 1 spec.; Parcel Manuel Luís; 1 Jun. 1993; UFMA* • 2 specs; 0206'54" S, 4401'15" W; depth 13 m; MNRJ 15306*. - Bahia • 1 spec.; JOPS st. 3238; MNRJ 33808*. - Campos Basin (Espírito Santo/Rio de Janeiro) • 8 specs; 22 $2^{\circ} 42^{\prime} \mathrm{S}, 40^{\circ} 40^{\prime} \mathrm{W}$; depth $10 \mathrm{~m}$; 2006; MNRJ 32352* - 2 specs; $22^{\circ} 42^{\prime} \mathrm{S}, 40^{\circ} 40^{\prime} \mathrm{W}$; depth $110 \mathrm{~m}$; MNRJ 19477* • 1 spec.; $22^{\circ} 42^{\prime} \mathrm{S}, 40^{\circ} 40^{\prime} \mathrm{W}$; depth $110 \mathrm{~m}$; MNRJ 30903* 2 specs; $22^{\circ} 42^{\prime} \mathrm{S}, 40^{\circ} 40^{\prime} \mathrm{W} ; 110 \mathrm{~m}$; MNRJ 31105* 2 specs; $22^{\circ} 42^{\prime} \mathrm{S}, 40^{\circ} 40^{\prime} \mathrm{W}$; depth

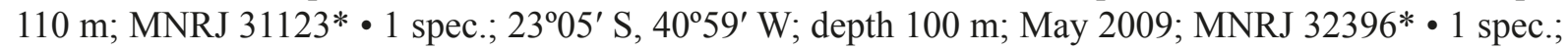
$23^{\circ} 05^{\prime} \mathrm{S}, 40^{\circ} 58^{\prime} \mathrm{W}$; depth $100 \mathrm{~m}$; 2004; MNRJ 30895* 3 specs; $23^{\circ} 05^{\prime} \mathrm{S}, 40^{\circ} 58^{\prime} \mathrm{W}$; depth $100 \mathrm{~m}$; 2004; MNRJ 32638* 8 specs; $23^{\circ} 05^{\prime} \mathrm{S}, 40^{\circ} 58^{\prime} \mathrm{W}$; depth $100 \mathrm{~m}$; 2004; MNRJ 32538* 2 specs; $23^{\circ} 05^{\prime} \mathrm{S}$, $40^{\circ} 58^{\prime} \mathrm{W}$; depth $100 \mathrm{~m}$; 2004; MNRJ 35543* - 1 spec.; $23^{\circ} 06^{\prime} 00^{\prime \prime} \mathrm{S}, 41^{\circ} 06^{\prime} 00^{\prime \prime} \mathrm{W}$; depth $88 \mathrm{~m}$; Oct. 2008; MNRJ 32037*. - São Paulo • 1 spec.; Ubatuba, Enseada do Flamengo; 25 Jun. 1956; C. de Jesus leg.; MZSP 52120 • 3 specs; PADCT st. 6571; MNRJ 29368* • 1 spec.; PADCT st. 6571; MZSP 133491 - 2 specs; REVIZEE-Sul st. 6666; MZSP 133500 • 5 specs; PADCT st. 6573; MNRJ 27849* • 1 spec.; REVIZEE-Sul st. 6678; MNRJ 29369* 2 specs; REVIZEE-Sul st. 6676; MZSP 133503 • 10 specs; PADCT st. 6577; MNRJ 29370* • 2 specs; REVIZEE-Sul st. 6646; MNRJ 29367* • 1 spec.; PADCT st. 6641; MNRJ $60194 \cdot 2$ specs; PADCT st. 6642; MNRJ 27848*.

UNITED STATES OF AMERICA - North Carolina 3 specs [this lot also contains paralectotypes of Metaxia taeniolata, listed below]; south of Cape Lookout; depth 95 m; R/V Albatross leg.; 19 Oct. 1885; USNM 92745. - Louisiana • 3 specs; 55-65 m; BMSM 67395.

\section{Metaxia taeniolata (Dall, 1889)}

Cerithiopsis metaxae var. taeniolata Dall, 1889: 256.

Cerithiopsis metaxae var. taeniolata - Dall 1892: 270. — Abbott 1974: 109.

Metaxia taeniolata - Rolán \& Fernández-Garcés 1992: 173-174, figs 3, 8; 2007: pl. IV figs 13-14. Fernandes \& Pimenta 2011: 822, figs 7-11. — Fernandes \& Segadilha 2019: 133, fig. 3f.

Metaxia exilis non C.B. Adams, 1850 - Odé 1989: 105, fig. 1.

Cerithiopsis rugulosum non C.B. Adams, 1850 - Merlano \& Hegedus 1994: 146, pl. XLVI fig. 512.

Metaxia excelsa non Faber \& Moolenbeek, 1991 - Tunnell et al. 2010: 205.

Metaxia rugulosa non C.B. Adams, 1850 - Rolán \& Fernández-Garcés 2015: 54, pl. 4 fig. g. — Lamy \& Pointier 2018: 287, pl. 92 fig. 3.

\section{Material examined}

BRAZIL - North Brazil • 1 spec.; REVIZEE-Norte III st. 175; UFMA* • 6 specs; REVIZEE-Norte III st. 176; UFMA*. - Rio Grande do Norte - 1 spec.; BPot 1-MR25; MNRJ 31453*. - Bahia • 23 specs; Baía de Todos os Santos; Jun. 1997; MNRJ 34426* • 2 specs; Ilhéus; MNRJ 32380* • 9 specs; Ilhéus; MNRJ 32971*. - Espírito Santo • 1 spec.; Porto de Ubú; 2047' S, 40³2' W; MNRJ 31058* • 1 spec.; Porto de Ubú; $20^{\circ} 47^{\prime}$ S, 40³2' W; MNRJ 31082* • 3 specs; Porto de Ubú; $20^{\circ} 47^{\prime}$ S, $40^{\circ} 32^{\prime}$ W; MNRJ 32415*. - Vitória-Trindade Chain • 2 specs; REVIZEE-Central C2-22R; MORG 41675. - 
São Paulo • 1 spec.; Ubatuba, Praia da Enseada; MZSP 51948 • 1 spec.; Guarujá; M.A. Cardoso leg.; MZSP 17753.

UNITED STATES OF AMERICA - North Carolina - 3 specs [paralectotypes; this lot also contains shells of Metaxia rugulosa, listed above]; south of Cape Lookout; depth 95 m; R/V Albatross leg.; 19 Oct. 1885; USNM 92745. - South Carolina • 1 spec., lectotype; depth 33 m; R/V Albatross leg.; 20 Oct. 1885; USNM 92746.

Cosmotriphora arnoldoi Faber \& Moolenbeek, 1991

Fig. 87

Cosmotriphora arnoldoi Faber \& Moolenbeek, 1991: 81, figs 1-2.

Triphora sp. D - Rice \& Kornicker 1962: 120, pl. 2 fig. 17.

Cosmotriphora arnoldoi - Rolán \& Fernández-Garcés 1994: 20, figs 12-15; 2007: 20, pl. 1 figs 19-21. — Lee 2009: 88. — Garcia \& Lee 2011. — Fernandes et al. 2013: 4, figs 2, 18, 29.

\section{Material examined}

BRAZIL - Rio Grande do Norte • 2 specs; BPot 1-MR42; MNRJ 31497* • 1 spec.; 0444'53" S, 36²5'27" W; depth 102-108 m; 23 May 2011; MNRJ 35117*. - Sergipe • 1 spec.; Petro/UFS st. 12.1; UFS - 2 specs; Petro/UFS st. 18.1; UFS. - Bahia • 3 specs; Ilhéus; MNRJ 32378* • 1 spec.; Canavieiras; Apr. 2011; MNRJ 30756*. - Espírito Santo • 2 specs; REVIZEE-Central C1-C65; MORG 52597 • 9 specs; REVIZEE-Central C1-VV38; IBUFRJ 19501 • 9 specs; REVIZEE-Central C1-VV38; IBUFRJ 19608 • 3 specs; REVIZEE-Central C1-VV38; MORG 40339 • 1 spec.; 19²6'03" S, 39²2'35" W; depth 44 m; Oct. 2003; MNRJ 32837*. - Campos Basin (Espírito Santo/Rio de Janeiro) • 3 specs; REVIZEE-Central C1-VV16; IBUFRJ 19487 • 1 spec.; REVIZEE-Central C1-VV21; IBUFRJ 19543 • 1 spec.; $20^{\circ} 42^{\prime}$ S, 4006' W; 27 Aug. 1979; OC. Ship Almirante Câmara leg.; IBUFRJ 19549 • 6 specs; REVIZEE-Central C1-D3; IBUFRJ 19584 • 1 spec.; HAB 13-H4; MNRJ 17945* • 1 spec.; HAB 16-H3; MNRJ 18437* - 2 specs; HAB 17-I3; MNRJ 18438* • 4 specs; HAB 17-I2; MNRJ 18439* • 1 spec.; HAB 13-I2; MNRJ 18675* • 1 spec.; HAB 13-H3; MNRJ 18676* • 1 spec.; HAB 11-G4; MNRJ 18681* 1 spec.; 230'' S, 4059' W; 17 Jul. 2004; MNRJ 18967* • 1 spec.; Campos Basin; May 2009; MNRJ 32395*

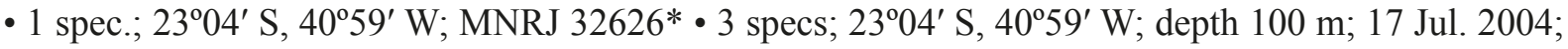

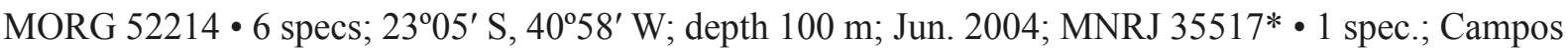

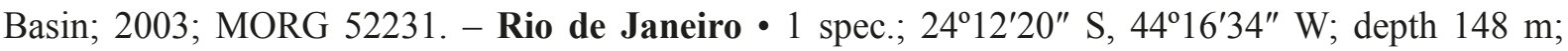
Oct. 2008; MNRJ 32041* • 3 specs; REVIZEE-Sul st. 6662; MNRJ 29383*. - São Paulo • 5 specs; PADCT st. 6571; MNRJ 29381* • 5 specs; PADCT st. 6571; MNRJ 60190 • 1 spec.; PADCT st. 6579; MNRJ 29371*• 1 spec.; PADCT st. 6573; MNRJ 29376*•1 spec.; REVIZEE-Sul st. 6676; MZSP 133502 - 2 specs; REVIZEE-Sul st. 6678; MNRJ 29384* • 2 specs; PADCT st. 6577; MZSP 133493 • 1 spec.; REVIZEE-Sul st. 6669; MNRJ 29375* • 1 worn spec.; REVIZEE-Sul st. 6669; MNRJ 60186. - Santa Catarina • 1 worn spec.; PADCT st. 6635; MNRJ 27845*.

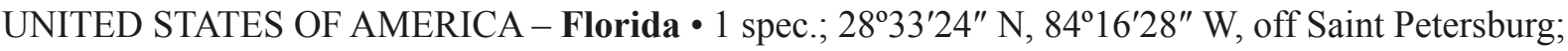
24 May 2012; G. Paulay leg.; with soft part preservation; FLMNH 450465.

\section{Remarks}

Some shells of C. arnoldoi from Brazil reach $5.0 \mathrm{~mm}$ in length, which is smaller than the $6.0 \mathrm{~mm}$ length attained by shells from Cuba (Rolán \& Fernández-Garcés 1994). The holotype, an adult shell from Bonaire, measures only $2.8 \mathrm{~mm}$ long (Faber \& Moolenbeek 1991), similar to the $2.34 \mathrm{~mm}$ length of an 

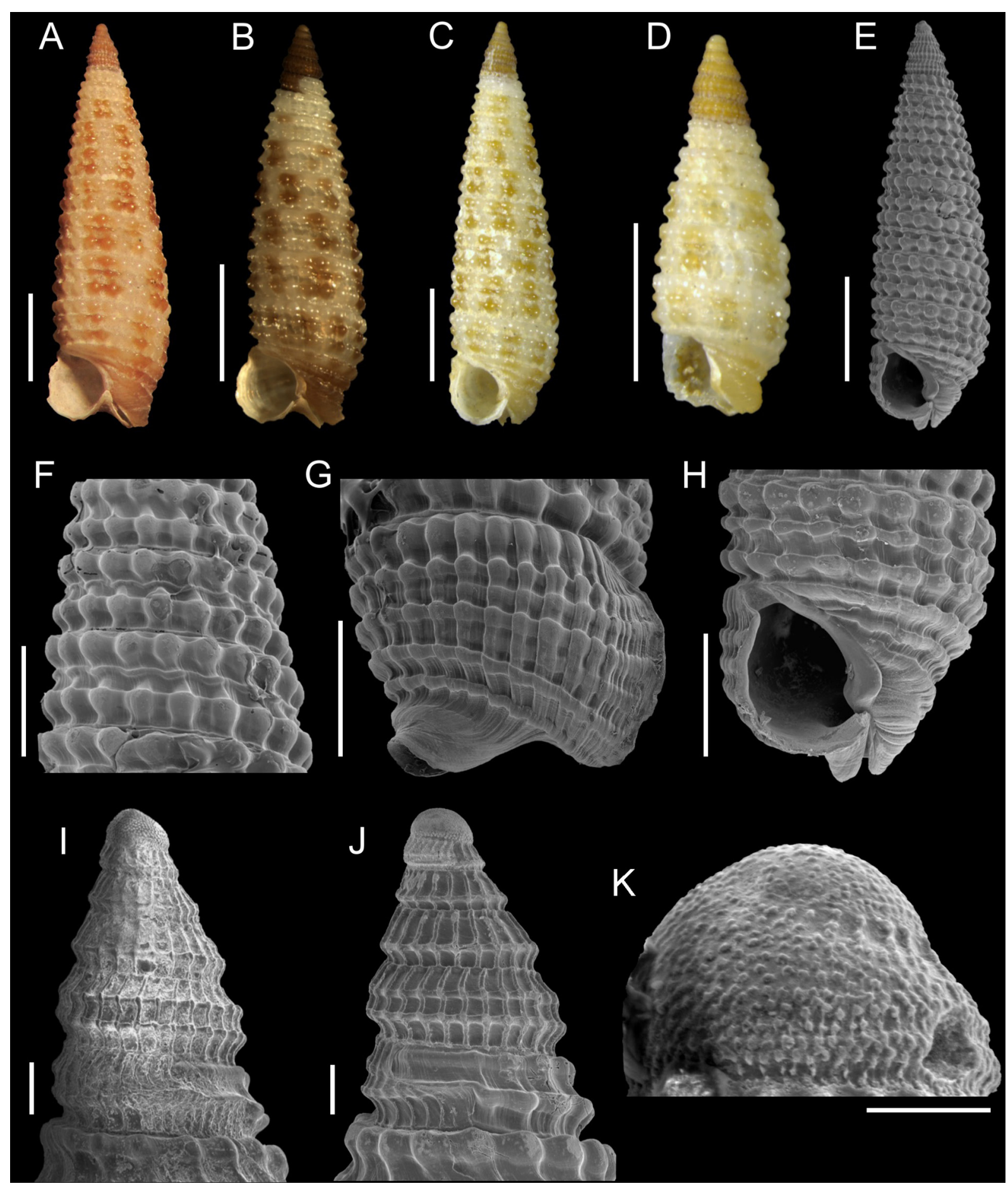

Fig. 87. Cosmotriphora arnoldoi Faber \& Moolenbeek, 1991. A. MNRJ 18675*, $4.62 \mathrm{~mm}$. B. MNRJ 18681*, $3.47 \mathrm{~mm}$. C. MNRJ 30756*, $4.37 \mathrm{~mm}$. D. MNRJ 32378*, $2.34 \mathrm{~mm}$. E. MNRJ 18439*, $3.93 \mathrm{~mm}$. F-H, J. Same shell as E. I. Same shell as C. K. Same shell as B. Scale bars: A-E $=1 \mathrm{~mm} ; \mathrm{F}-\mathrm{H}=500 \mu \mathrm{m} ; \mathrm{I}-\mathrm{J}=100 \mu \mathrm{m} ; \mathrm{K}=50 \mu \mathrm{m}$. 
Cosmotriphora melanura (C.B. Adams, 1850)

Fig. 88

Cerithium melanura C.B. Adams, 1850: 117.

Cerithium moniliferum Lea, 1843 non Deshayes, 1833: 269, pl. 37 fig. 92.

Cerithium dealbatum C.B. Adams, 1850: 117. New synonymy.

Cerithium submoniliferum d'Orbigny, 1852: 83.

Triforis grimaldii Dautzenberg \& Fischer, 1906: 41, pl. 3 figs 9-10. Uncertain synonymy.

Triforis melanura - Smith 1890: 291 (it requires confirmation). — Dall 1892: 264. — Dall \& Simpson 1901: 423 , pl. 58 fig. 7.

Cerithium melanura - Clench \& Turner 1950: 307, pl. 38 fig. 10.

Cerithium dealbatum - Clench \& Turner 1950: 271, pl. 38 fig. 3.

Triphora melanura - Parker \& Curray 1956: 2434. — Warmke \& Abbott 1962: 76, pl. 13 fig. 1. Rice \& Kornicker 1962: 120, pl. 2 fig. 13. — Rios 1970: 45; 1975: 50, pl. 13 fig. 187; 1985: 161, pl. 53 fig. 761; 1994: 94, pl. 31 fig. 374; 2009: 172. — Abbott 1974: 111, fig. 1134. — Ekdale 1974: 644. - Vokes \& Vokes 1983: 18, pl. 27 fig. 14. — De Jong \& Coomans 1988: 49. — Absalão 1989: 3. — Díaz 1994: 33. — Hess \& Abbott 1994: 147. — Merlano \& Hegedus 1994: 148, pl. 46 fig. 524. — Rocha et al. 1997: 23. — Barros et al. 2002: 31. — Coelho-Filho 2004: 25. — Absalão et al. 2006: 238, fig. 9. — Gomes et al. 2006: 188. — Montagna 2006: 23. — Daccarett \& Bossio 2011: 92, fig. 420.

Triphora dealbatum - Treece 1980: 560.

Triphora (Cosmotriphora) melanura - Odé 1989: 109, fig. 3.

Cosmotriphora melanura - Marshall 1983: 110, pl. 27 figs d-f. - Bouchet 1985: 35, figs 2, 16, 27 (it requires confirmation). - Fernandes \& Rolán 1988: 22, pl. 1 fig. 1, pl. 2 fig. 2 (it requires confirmation); 1993: 35 (it requires confirmation). — Leal 1991: 120, pl. 16 figs f-g. — Rolán \& Fernández-Garcés 1994: 19, figs 11, 25-26, 30 CM; 2007: 20, pl. 1 figs 14-16; 2015: 54, pl. 4 fig. c. — Redfern 2001: 65, pl. 32 fig. 274; 2013: 128, fig. 362. — Espinosa \& Ortea 2001: 20. Ardovini \& Cossignani 2004: 134 (it requires confirmation). — Rolán 2005: 106, pl. 30 fig. 438 (it requires confirmation). — Cruz \& Gándara 2006: 132. — Jensen \& Pearce 2009: 128. — Lee 2009: 88. - Oliveira et al. 2009: 180. — Tunnell et al. 2010: 204. — Garcia \& Lee 2011. — Zhang 2011: 99, fig. 290. — Espinosa et al. 2012: 257. — García \& Capote 2012: 22; 2013: 29. — Fernandes et al. 2013: 5, figs 3, 19, 30. — Lamy \& Pointier 2018: 284, pl. 91 fig. 5a-b. — Fernandes \& Pimenta 2019a: 15, figs $2 \mathrm{c}, 7-8$.

\section{Material examined}

BAHAMAS • 1 spec.; Abaco; C. Redfern leg.; BMSM 55420 • 5 specs; Abaco; C. Redfern leg.; BMSM 55422 • 8 specs; Abaco; C. Redfern leg.; BMSM 55423 • 7 specs; Abaco; C. Redfern leg.; BMSM 55424.

BRAZIL - North Brazil • 2 specs; REVIZEE-Norte III st. 176; UFMA* 5 specs; REVIZEE-Norte III st. 211A; UFMA*. - Amapá • 1 spec.; 0358'43" N, 49³3'24" W; 2001; MNRJ 32572* • 1 spec.; AMASSEDS st. 4134; MNRJ 34459* - 2 specs; 02 ${ }^{\circ} 11^{\prime} 18^{\prime \prime} \mathrm{N}, 47^{\circ} 49^{\prime} 18^{\prime \prime} \mathrm{W}$; depth 75-80 m; 8 Nov.

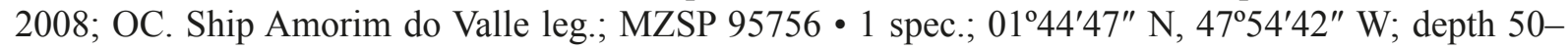
63 m; 10 Nov. 2008; OC. Ship Amorim do Valle leg.; with soft part preservation; MZSP 94628. Pará - 6 specs; $00^{\circ} 48^{\prime} \mathrm{N}, 45^{\circ} 36^{\prime} \mathrm{W}$; depth $55 \mathrm{~m}$; Jan. 1981; MORG 21711. - Maranhão • 1 spec.; $01^{\circ} 30^{\prime} 33^{\prime \prime}$ S, 4320'28" W; depth 59 m; 22 Nov. 2008; OC. Ship Amorim do Valle leg.; MZSP 94407. - Ceará • 1 spec.; 02³2'00" S, 39²2'00" W; depth 48 m; 7 Nov. 1990; OC. Ship Victor Hensen leg.;

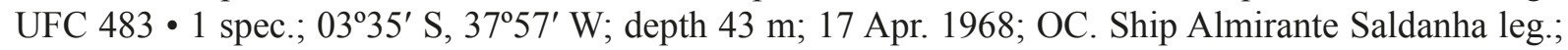
MORG $13105 \cdot 3$ specs; 033' S, 38 $18^{\circ}$ W; depth 27 m; 17Apr. 1968; OC. Ship Almirante Saldanha leg.; MORG 14781. - Rio Grande do Norte • 3 specs; BPot 1-MR31; MNRJ 31498* • 2 specs; 
BPot 1-MR32; MNRJ 31499* • 12 specs; BPot 1-MR41; MNRJ 31500* • 17 specs; BPot 1-MR42; MNRJ 31501* • 18 specs; BPot 1-MR43; MNRJ 31502* • 9 specs; BPot 1-MR44; MNRJ 31503* • 11 specs; BPot 1-MR45; MNRJ 31504* 10 specs; BPot 2-MR42; MNRJ 31505* • 22 specs; BPot 2-MR44; MNRJ 31506*• 18 specs; BPot 2-MR45; MNRJ 31507*• 1 spec.; 04³3'17" S, 36 56'35" W;
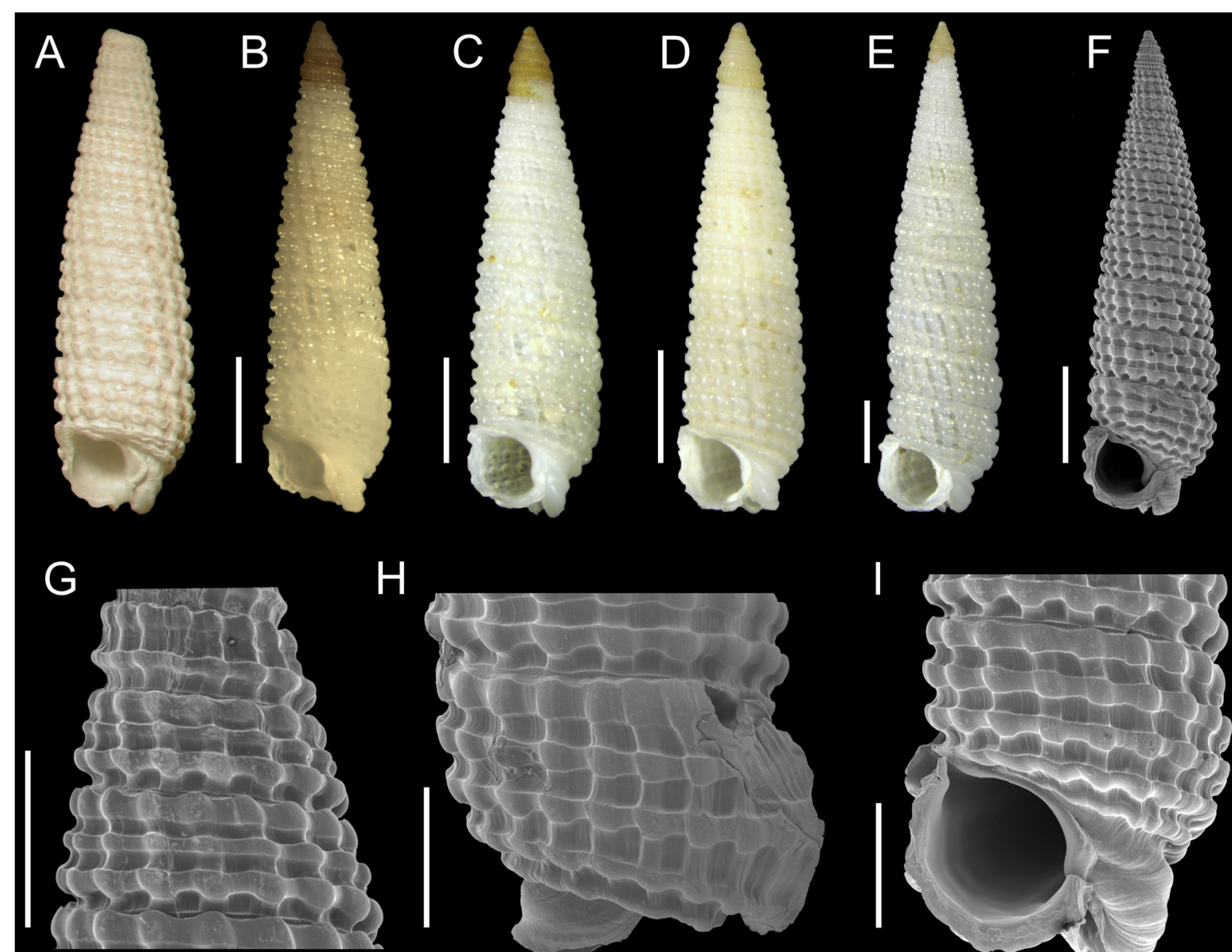

$\mathrm{H}$
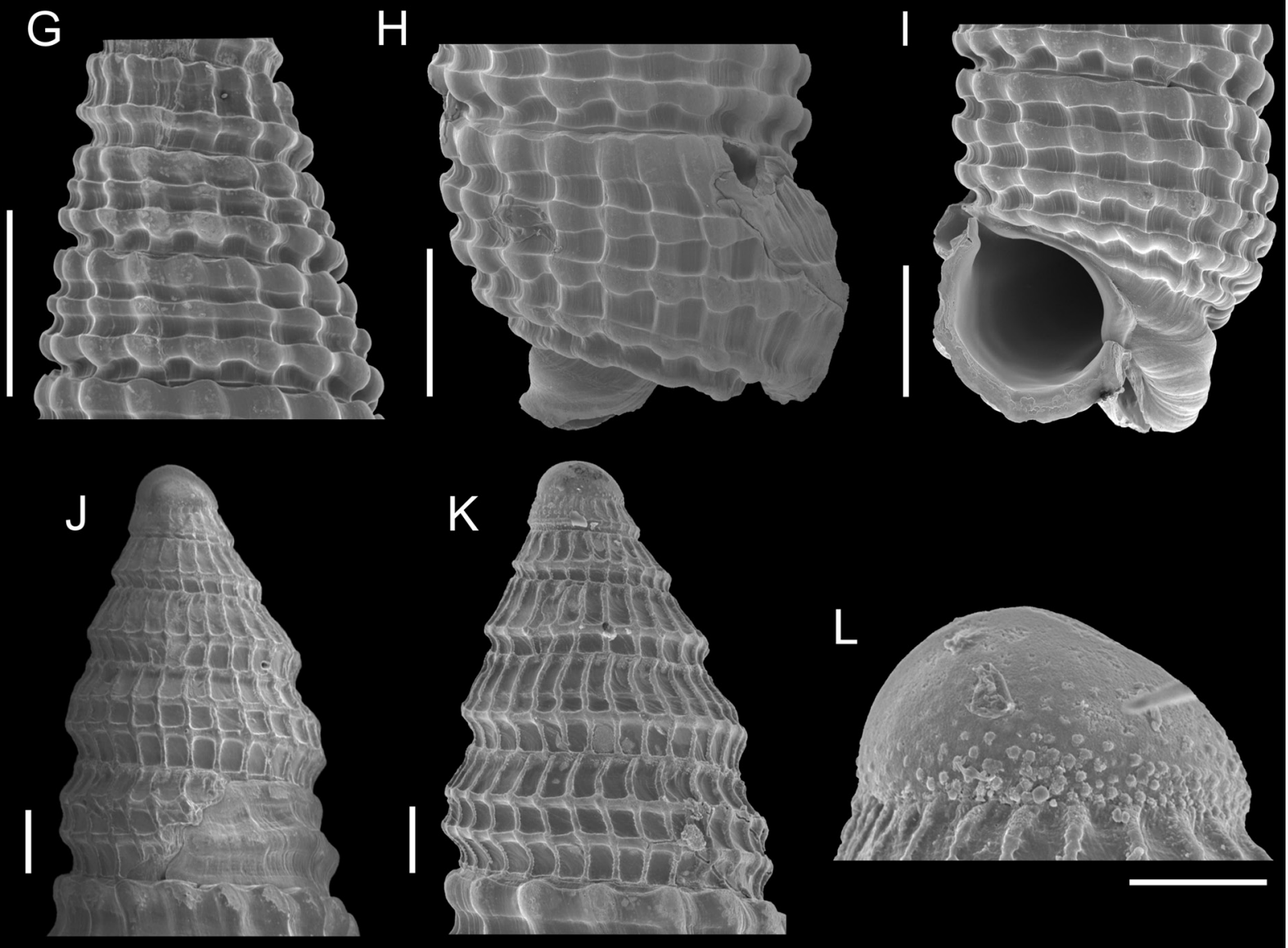

Fig. 88. Cosmotriphora melanura (C.B. Adams, 1850). A. Lectotype, MCZ 186159. B. MNRJ 18409*, $4.64 \mathrm{~mm}$. C. MNRJ 31498*, $4.68 \mathrm{~mm}$. D. MNRJ 32607*, $4.36 \mathrm{~mm}$. E. MNRJ 32996*, $7.87 \mathrm{~mm}$. F. MNRJ 18409*, $5.06 \mathrm{~mm}$. G-I, K-L. Same shell as F. J. Same shell as E. Scale bars: B-F = $1 \mathrm{~mm} ; \mathrm{G}-\mathrm{I}=500 \mu \mathrm{m} ; \mathrm{J}-\mathrm{K}=100 \mu \mathrm{m} ; \mathrm{L}=50 \mu \mathrm{m}$. 
depth 130-160 m; 21 May 2011; MNRJ 35178* • 1 spec.; 0436'43" S, 3646'45" W; depth 140 m;

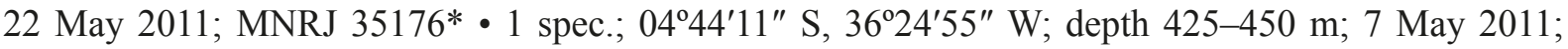

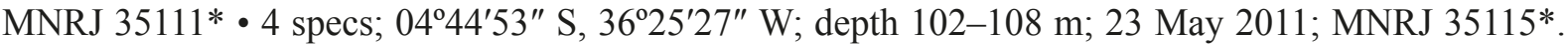
- Fernando de Noronha Archipelago • 1 spec.; Buraco do Inferno; 034' $30^{\prime \prime}$ S, 32 $22^{\circ} 42^{\prime \prime}$ W; 3 May 2005; L.R.L. Simone leg.; MZSP 49038. - Pernambuco • 2 specs; $08^{\circ} 42^{\prime}$ S, 34 $34^{\circ} 4^{\prime}$ W; depth 480 m; 30 Jan. 2001; OC. Ship Antares leg.; MORG 49346*. - Alagoas - 1 spec.; Ponta Verde, Maceió; P. Cardoso leg.; FLMNH 151634 • 1 spec.; Ponta Verde, Maceió; P. Cardoso leg.; MORG 33739 • 2 specs; Jaraguá, Maceió; MNRJ 18609* • 4 specs; Jaraguá, Maceió; MORG 18262 • 56 specs; Jaraguá, Maceió; MORG 33737 • 1 spec.; Petro/MAR st. 19; UFS • 14 specs; Petro/MAR st. 21; UFS. - Sergipe - 2 specs; Petro/UFS st. E5-A1; with soft part preservation; UFS - 3 specs; Petro/UFS st. E5-A2; with soft part preservation; UFS • 36 specs; Petro/UFS st. E6-A1; UFS • 1 spec.; Petro/UFS st. E6-A2; with soft part preservation; UFS • 38 specs; Petro/UFS st. 15.3; UFS • 19 specs; Petro/UFS st. 18.1; UFS. Bahia 7 specs; Salvador, Itapuã; MNRJ 41469* • 36 specs; Salvador, Itapuã; MORG 33728 • 4 specs; Salvador, Itapuã; MZSP 133320 • 3 specs; Salvador, Itapuã; 17 Jul. 1967; E. Rios leg.; MORG 13821 • 11 specs; Salvador, Itapuã; 17 Jul. 1967; E. Rios leg.; MORG 16398 • 30 specs; Salvador, intertidal pool; May 1982; G. Oliveira leg.; MNRJ 21362* 15 specs; Salvador, intertidal pool; Nov. 1991; G. Oliveira leg.; MORG 41454 • 5 specs; Salvador; MZSP 64873 • 2 specs; off Camamú; depth 52 m; 11 Dec. 2002; MORG 52617 • 5 specs; $13^{\circ} 28^{\prime} 16^{\prime \prime}$ S, 38 $48^{\prime} 43^{\prime \prime}$ W; depth 35 m; 24 Nov. 2007; MNRJ 32607* •

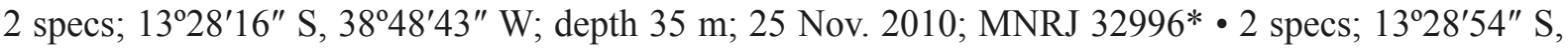

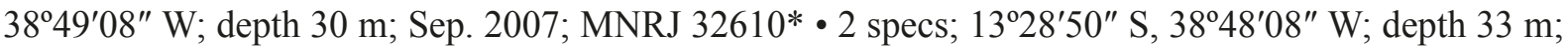

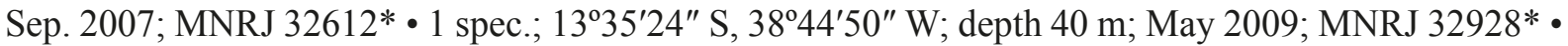
2 specs; Boipeba;1335'44" S, 3849'04" W; 31 Mar. 2003; MNRJ 17254* • 1 spec.; Baía de Camamu; M. Ximenes and V. Abud leg.; Dec. 2001; MNRJ 18945*• 1 spec.; 15³4' S, 3840' W; depth 54 m; Oct. 2005; MNRJ 30699* 53 specs; Ilhéus; MNRJ 32369* • 2 specs; Canavieiras; Apr. 2011; MNRJ 30722* - 1 spec.; Canavieiras; Apr. 2011; MNRJ 32364* - 2 specs; off Belmonte; depth 48 m; Sep. 1968;

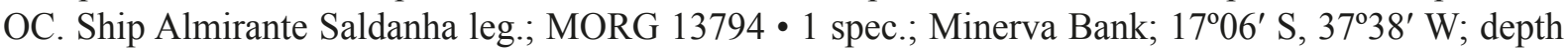
120 m; Aug. 2012; MZSP 110974 • 1 spec.; REVIZEE-Central C1-C76; IBUFRJ 9686 • 59 specs; REVIZEE-Central C5-7R; IBUFRJ 14378 • 6 specs; REVIZEE-Central C2-7R; MNRJ 12739* •2 specs; REVIZEE-Central C5-13R; IBUFRJ 13317 • 5 specs; REVIZEE-Central C5-12R; MNRJ 12777* • 3 specs; REVIZEE-Central C2-10R; IBUFRJ 10631 - 2 specs; Abrolhos; Jan. 1985; MORG 38626. - Espírito Santo • 1 spec.; REVIZEE-Central C1-C65; IBUFRJ 12889 • 4 specs; REVIZEE-Central C1-C64; IBUFRJ 12888 • 1 spec.; REVIZEE-Central C1-C64; IBUFRJ 19493 • 1 spec.; REVIZEECentral C5-20R; IBUFRJ 13316 - 12 specs; REVIZEE-Central C1-VV38; IBUFRJ 12890 - 1 spec.; $19^{\circ} 25^{\prime} 34^{\prime \prime} \mathrm{S}, 39^{\circ} 22^{\prime} 16^{\prime \prime} \mathrm{W}$; depth 42 m; Oct. 2003; MNRJ 32602* 1 spec.; $19^{\circ} 26^{\prime} \mathrm{S}, 39^{\circ} 22^{\prime} \mathrm{W}$; depth 46 m; Oct. 2003; MNRJ 30706* 1 spec.; 19²6' S, 39²2' W; depth 46 m; Oct. 2003; MNRJ 30725* • 2 specs; $19^{\circ} 26^{\prime} \mathrm{S}, 39^{\circ} 22^{\prime} \mathrm{W}$; depth 46 m; Oct. 2003 MNRJ 32839* 1 spec.; $19^{\circ} 26^{\prime} 19^{\prime \prime} \mathrm{S}, 39^{\circ} 15^{\prime} 17^{\prime \prime} \mathrm{W}$; depth 53 m; Oct. 2003; MNRJ 30713* • 2 specs; REVIZEE-Central C1-VV24; IBUFRJ 12887 • 1 spec.; REVIZEE-Central C1-VV24; MORG 52257 • 4 specs; 20¹8' S, 40¹4' W; Mar. 1993; V. Abud leg.; MORG 40030 • 1 spec.; Guarapari; 1970; MORG 22003 • 4 specs; Piúma; 1993; IBUFRJ 8584. Vitória-Trindade Chain • 2 specs; Trindade Island; depth 10 m; Mar. 1986; MORG 24415 - 1 spec.; Trindade Island, Praia dos Portugueses; depth 12-18 m; 21 May 1950; MNHN-Mo 8010* • 2 specs; Trindade Island, Fundeadouro; depth 12 m; 15 Sep. 1987; L. Barcellos and L. Laurino leg.; MORG 25579 - 1 spec.; Trindade Island; 20⒉ $29^{\prime} 40^{\prime \prime}$ S, 29 20'33" W; depth 12 m; 2 Apr. 2014; J. Mendonça leg.;

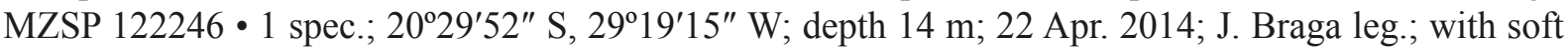
part preservation; MZSP 118269 • 1 spec.; Trindade Island; 20 $30^{\prime} 21^{\prime \prime} \mathrm{S}, 24^{\circ} 18^{\prime} 44^{\prime \prime} \mathrm{W}$, depth $13 \mathrm{~m}$; 18 Jul. 2013; D. Abbate leg.; MZSP 115553 • 1 spec.; Trindade Island, Ilha da Racha; 20³0'26" S, $29^{\circ} 20^{\prime} 48^{\prime \prime}$ W; depth 22 Jun. 2012; with soft part preservation; MZSP 109631 - 2 specs; Trindade Island, Praia da Calheta; 203'6" S, 29 $18^{\prime} 44^{\prime \prime}$ W; 18 Jun. 2012; MZSP 109764. - Campos Basin (Espírito Santo/Rio de Janeiro) • 2 specs; 2042' S, 4006' W; 28 Aug. 1979; OC. Ship Almirante Câmara leg.;

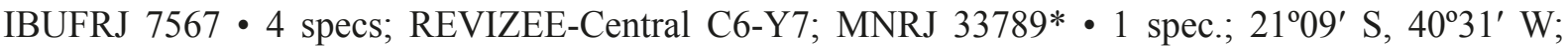


27 Aug. 1979; OC. Ship Almirante Câmara leg.; IBUFRJ 7669 • 1 spec.; REVIZEE-Central C2-36R; IBUFRJ 10703 • 1 spec.; REVIZEE-Central C1-VV22; IBUFRJ 11367 • 1 spec.; REVIZEE-Central C1-VV22; MORG $41734 \cdot 1$ spec.; $21^{\circ} 15^{\prime}$ S, 4020' W; 28 Aug. 1979; OC. Ship Almirante Câmara leg.; IBUFRJ 19513 • 2 specs; 205' S, 40¹2' W; 26 Aug. 1979; OC. Ship Almirante Câmara leg.; IBUFRJ $19518 \bullet 8$ specs; REVIZEE-Central C1-VV21; IBUFRJ 19537 • 11 specs; REVIZEE-Central C1-VV21; MNRJ 33794* • 1 spec.; REVIZEE-Central C1-VV17; IBUFRJ 19560 • 3 specs; $22^{\circ} 42^{\prime}$ S, 4040 W; depth 5-10 m; Mar. 2007; MNRJ 15401*• 1 spec.; HAB 13-H1; MNRJ 17963* • 2 specs; HAB 13-H2; MNRJ 17975* • 3 specs; HAB 13-I2; MNRJ 17978* • 1 spec.; HAB 11-G4; MNRJ 17979* • 1 spec.; HAB 11-C4; MNRJ 17981* • 1 spec.; HAB 16-B4; MNRJ 18367* • 2 specs; HAB 16-H2; MNRJ 18404* • 6 specs; HAB 17-I2; MNRJ 18409* • 3 specs; HAB 16-H3; MNRJ 18417* 1 spec.; $23^{\circ} 04^{\prime} \mathrm{S}, 40^{\circ} 59^{\prime} \mathrm{W} ; 17$ Dec. 2004; MNRJ 18970* 1 spec.; $23^{\circ} 05^{\prime} \mathrm{S}, 40^{\circ} 58^{\prime} \mathrm{W}$; depth $100 \mathrm{~m}$; 2004; MNRJ 30866* 2 specs; $23^{\circ} 05^{\prime} \mathrm{S}, 40^{\circ} 58^{\prime} \mathrm{W}$; depth $100 \mathrm{~m}$; 2004; MNRJ 32639* 1 spec.; $23^{\circ} 09^{\prime} 00^{\prime \prime} \mathrm{S}$, 4102'06" W; Oct. 2008; MNRJ 32076* • 1 spec.; REVIZEE C1-VV21; MORG 52202 • 1 spec.; Campos Basin; 2003; MORG 52232. - Rio de Janeiro • 1 spec.; Búzios, Praia da Ferradura; MNRJ 18598*.

COLOMBIA • 1 spec.; Tayrona, Cabo de la Aguja; $11^{\circ} 18^{\prime} 17^{\prime \prime}$ N, $74^{\circ} 11^{\prime} 25^{\prime \prime}$ W; depth 8-17 m; 30 Dec; 1988; L. Escobar leg.; INV MOL950 • 1 spec.; Archipiélagos Coralinos; 0950'19" N, 76²10'19" W; depth 98 m; 30 Apr. 2005; A. Clavijo leg.; INV MOL6537.

VENEZUELA • 2 specs; Isla Margarita, Los Roques; depth 60 m; Dec. 2004; MZSP 65903.

UNITED STATES OF AMERICA - Florida • 3 specs; off Boynton Beach; depth 27-58 m; Sep. 1967 - 1 spec.; Deerfield Beach; depth 3-5 m; Jun. 1998; P. Souza leg.; MZSP 42454. - Louisiana • 1 spec.; depth 55-65 m; BMSM 51053.

\section{Remarks}

Rolán \& Fernández-Garcés (2008) suspected that Triphora dealbata (C.B. Adams, 1850) could be related to C. melanura (C.B. Adams, 1850), both described from Jamaica. The lectotype of T. dealbata is broken, without apex (Clench \& Turner 1950: pl. 38 fig. 3), but its teleoconch is equal to that of C. melanura. Because C. melanura has priority over T. dealbata, appearing at the top of the same page on which $T$. dealbata was described, $T$. dealbata is regarded as a junior synonym.

Eutriphora costai Fernandes \& Pimenta, 2015

Eutriphora costai Fernandes \& Pimenta, 2015: 498, fig. 3.

\section{Material examined}

BRAZIL - Bahia • 5 specs; Baía de Todos os Santos; Jun. 1997; MNRJ 34422*.

Iniforis pseudothomae Rolán \& Fernández-Garcés, 1993

Fig. 89

Iniforis pseudothomae Rolán \& Fernández-Garcés, 1993: 100, figs 5-8, 22-23.

Iniforis pseudothomae - Rolán \& Fernández-Garcés 2007: 21, pl. 2 figs 9-12. — Espinosa et al. 2007: 74; 2012: 257. — Fernandes et al. 2013: 7, figs 5, 21, 32. — García 2016: 106. — Lamy \& Pointier 2018: 286, pl. 91 fig. 12. — Fernandes \& Pimenta 2019a: 18, figs 2d, 9-11.

Triphora sp. 2 - Leal 1991: 123, pl. 16 figs 1-m.

Iniforis cf. pseudothomae - Rolán \& Fernández-Garcés 2015: 54, pl. 4 fig. j.

Triphora turristhomae non Holten, 1802 - Rios 2009: 173. 


\section{Material examined}

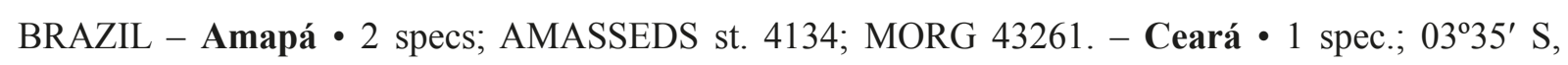
38¹9' W; depth 27 m; 17 Apr. 1968; OC. Ship Almirante Saldanha leg.; MORG 14978. - Rio Grande

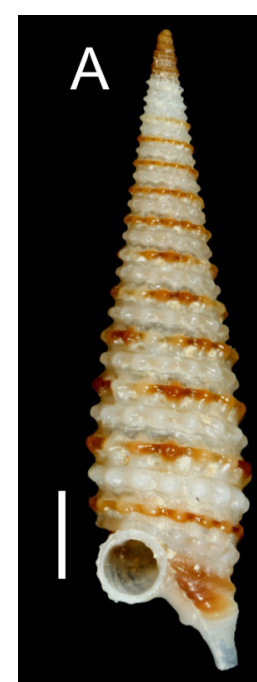

F

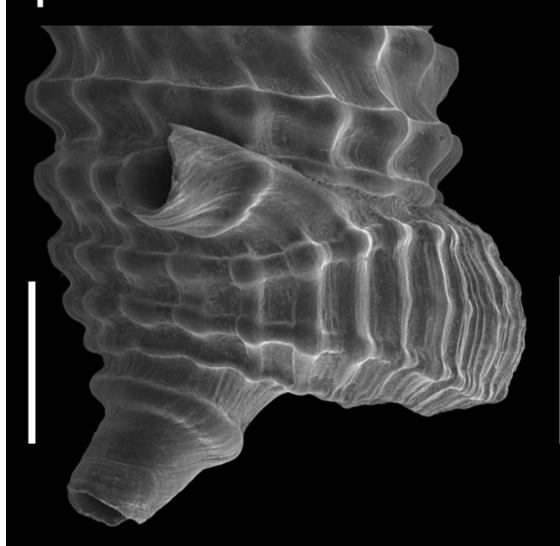

G
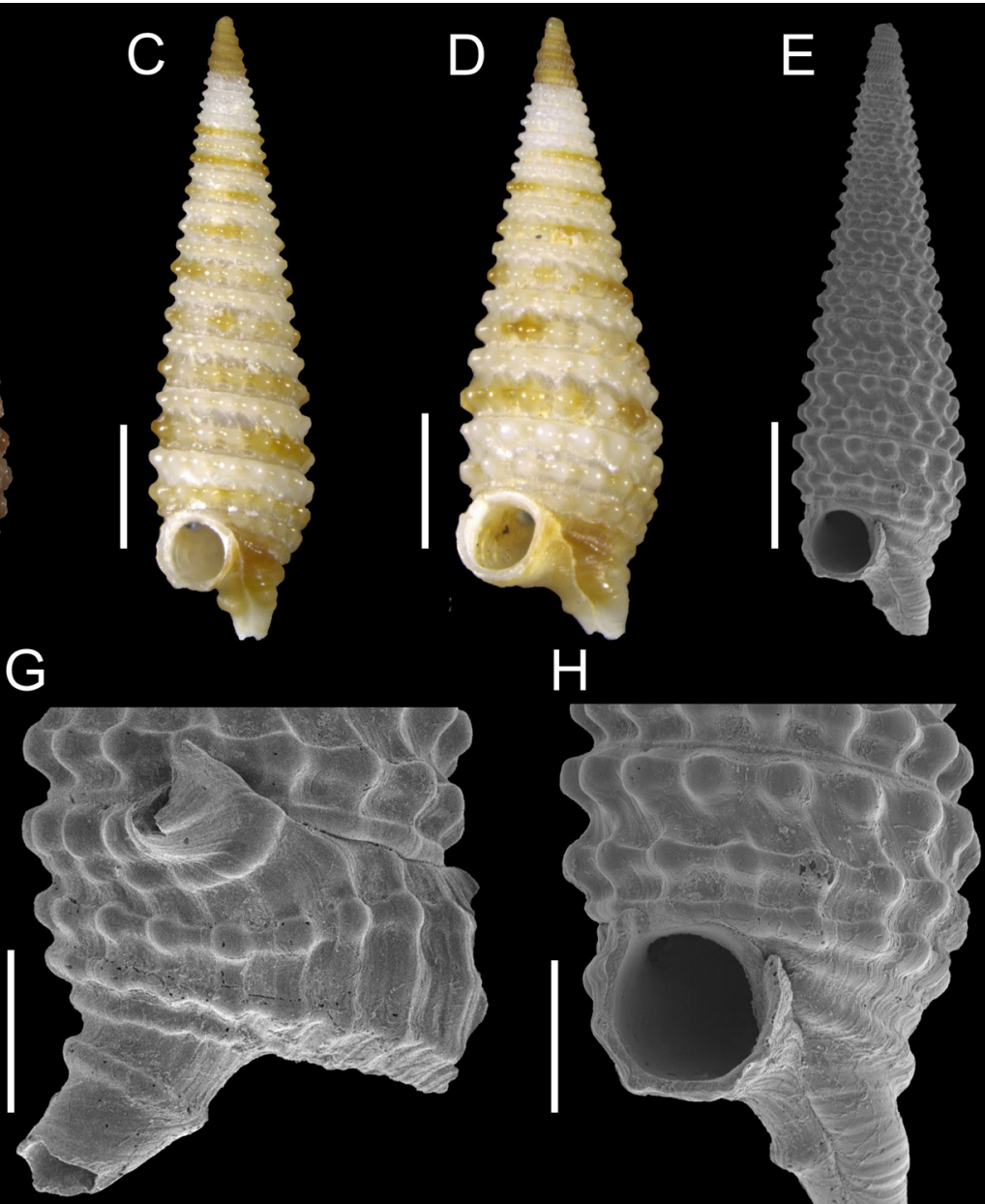

$\mathrm{H}$

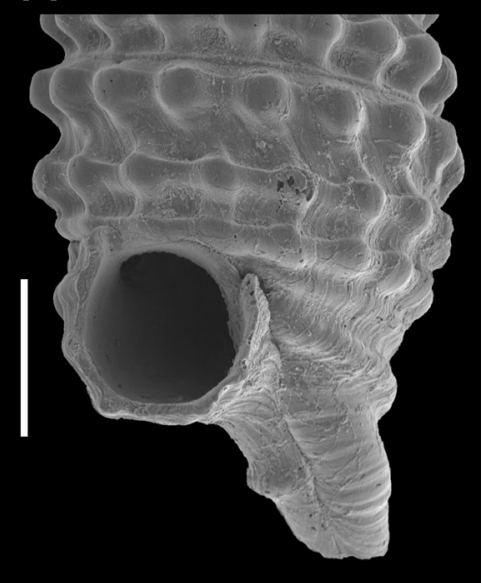

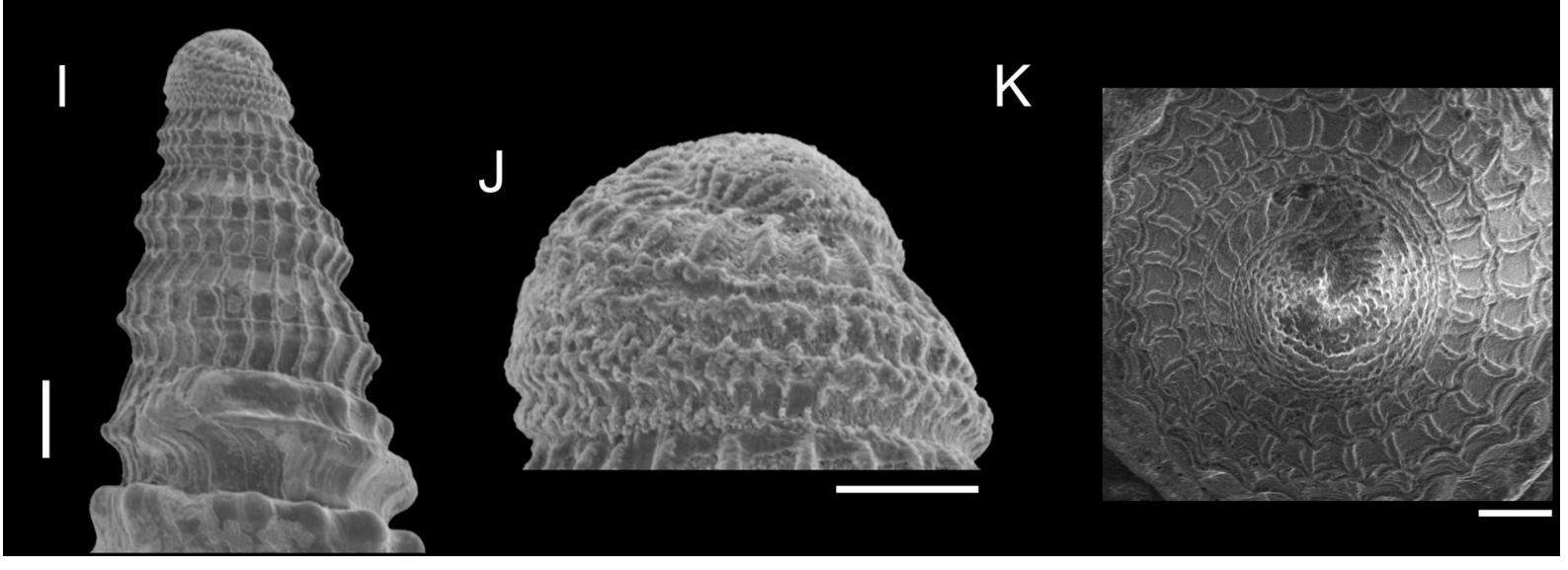

Fig. 89. Iniforis pseudothomae Rolán \& Fernández-Garcés, 1993. A. Holotype, MNCN 15.05/6820. B. IBUFRJ 19585, $4.58 \mathrm{~mm}$. C. MNRJ 31517*, $5.05 \mathrm{~mm}$. D. MNRJ 32973*, $4.60 \mathrm{~mm}$. E, G-H. Same shell as B. F, K. Same shell as C. I-J. MNRJ 18303. Scale bars: A-E $=1 \mathrm{~mm}$; F-H $=500 \mu \mathrm{m}$; I, K = $100 \mu \mathrm{m} ; \mathrm{J}=50 \mu \mathrm{m}$. Photo credits A: Rafael Araujo (MNCN). 
FERNANDES M.R. \& PIMENTA A.D., Update of Triphoridae from Brazil

do Norte • 1 spec.; BPot 1-MR32; MNRJ 31508* • 2 specs; BPot 1-MR41; MNRJ 31509* • 28 specs; BPot 1-MR42; MNRJ 31510* 16 specs; BPot 1-MR43; MNRJ 31511* 4 specs; BPot 1-MR44; MNRJ 31512* • 3 specs; BPot 1-MR45; MNRJ 31513* • 1 spec.; BPot 2-MR32; MNRJ 31514* • 20 specs; BPot 2-MR42; MNRJ 31515* • 21 specs; BPot 2-MR44; MNRJ 31516* - 7 specs; BPot 2-MR45; MNRJ 31517*. - Alagoas • 2 specs; Maceió, Ponta Verde; FLMNH $507942 ・ 1$ spec.; Maceió, Ponta Verde; MNRJ 56461* • 1 spec.; Maceió, Ponta Verde; MORG $12502 \cdot 3$ specs; Maceió, Ponta Verde; MORG 33726 • 3 specs; Maceió, Jaraguá; MNRJ 18607* • 3 specs; Maceió, Jaraguá; MORG 18263 - 85 specs; Maceió, Jaraguá; MORG 33730 • 25 specs; Maceió, Jaraguá; MORG 39255 • 4 specs; Petro/MAR st. 21; UFS. - Sergipe • 1 spec.; Petro/UFS st. 12.1; UFS • 1 worn spec.; 1130'42" S, 36 35'23" W, MARSEAL st. EN9-R2; depth 300 m; UFS. - Bahia • 1 spec.; Praia do Forte; L. Barcellos leg.; May 1987; MORG 25290 • 4 specs; Itapuã, Salvador; MORG $33749 \bullet 4$ specs; Baía de Todos os Santos; Jun. 1997; MNRJ 34427*• 1 spec.; off Boipeba; $13^{\circ} 35^{\prime}$ S, $38^{\circ} 50^{\prime}$ W, depth 35-55 m; Dec. 2002; M. Ximenez leg.; MORG 43758 - 1 spec.; Baía de Camamu; Dec. 2001; M. Ximenes and V. Abud leg.; MNRJ 18944* • 79 specs; Ilhéus; MNRJ 32368* 18 specs; Ilhéus; MNRJ 32973* • 55 specs; Ilhéus; MNRJ 32976* • 2 specs; Canavieiras; Apr. 2011; MNRJ 30723* • 3 specs; REVIZEE-Central C1-C76; IBUFRJ 10784 • 1 spec.; REVIZEE-Central C5-13R; IBUFRJ 14716 • 1 spec.; Abrolhos; Feb. 1978; MORG 52608 • 1 spec.; Abrolhos; Jan. 1985; MORG $23826 \bullet 1$ spec.; Abrolhos; Jan. 1985; MORG 52605* • 1 spec.; Abrolhos, Parcel Paredes; Jan. 1985; MORG 23281 • 2 specs; Abrolhos; depth 10-15 m; Jan. 1985; MORG 21230. - Espírito Santo - 2 specs; REVIZEE-Central C1-C65; IBUFRJ 19461 • 4 specs; REVIZEE-Central C1-C65; MORG 52600 • 1 spec.; REVIZEE-Central C1C64; IBUFRJ 9523 • 1 spec.; REVIZEE-Central C1-C64; IBUFRJ 12882 • 1 spec.; REVIZEE-Central C1-C63; IBUFRJ 9269 • 1 spec.; REVIZEE-Central C1-VV38; IBUFRJ 19505 • 3 specs; REVIZEECentral C1-VV38; IBUFRJ 19611 • 1 spec.; REVIZEE-Central C1-VV24; MORG 52256 • 1 spec.; Vitória; 20¹8' S, 40¹4' W; Mar. 1993; V. Abud leg.; MORG 52264 • 1 spec.; Ilha Escalvada, Guarapari; 2012; W. Vieira leg.; MNRJ 34030*•1 spec.; Porto de Ubú; 2047’ S, 40³2' W; 2007; MNRJ 30896*• 3 specs; Porto de Ubú; 2047' S, 40³2' W; 2007; MNRJ 32417*. - Vitória-Trindade Chain • 18 specs; REVIZEE-Central C2-22R; MORG 41746. - Campos Basin (Espírito Santo/Rio de Janeiro) • 3 specs; REVIZEE-Central C1-VV21; IBUFRJ 19542 • 6 specs; REVIZEE-Central C1-D3; IBUFRJ 19585 • 1 spec.; HAB 13-H1; MNRJ 17942* • 1 spec.; HAB 13-I2; MNRJ 17947* • 2 specs; HAB 17-I2; MNRJ 18628* • 1 spec.; REVIZEE-Central C1-VV22; MORG 40399. - Rio de Janeiro • 1 spec.; off Arraial do Cabo; depth 25-30 m; Mar. 2003; P. Gonçalves leg.; CHL.

Isotriphora tigrina Fernandes, Pimenta \& Leal, 2013

Isotriphora tigrina Fernandes, Pimenta \& Leal, 2013: 8, figs 7-8, 39-44.

Material examined

BRAZIL - Vitória-Trindade Chain • 1 spec.; REVIZEE-Central C5-23R; MNRJ 34257*.

Latitriphora albida (A. Adams, 1854)

Fig. 90

Triphoris albidus A. Adams, 1854: 278.

Triforis (Sychar) samanae Dall, 1889: 248.

Triforis (Sychar) samanae - Dall \& Simpson 1901: 423, pl. 54 fig. 18.

Triphora samanae - Warmke \& Abbott 1962: 77. — De Jong \& Coomans 1988: 51, pl. 34 fig. 245.

Triphora sp. 5 - Leal 1991: 124.

Latitriphora albida - Rolán \& Fernández-Garcés 1995: 14, figs 29-32; 2007: 22, pl. 3 figs 8-9; 2015:

53, fig. 4s. - Redfern 2001: 67, pl. 33 fig. 280; 2013: 128, fig. 365. - Espinosa et al. 2007: 
74; 2012: 257. — Lee 2009: 89. — Jensen \& Pearce 2009: 129. — Zhang 2011: 99, fig. 297. — Fernandes et al. 2013: 10, figs 11, 22. — Hewitt \& van Leeuwen 2017: 54. — Lamy \& Pointier 2018: 286, pl. 91 fig. 15. — Fernandes \& Pimenta 2019a: 21, figs 2e, 12-13.

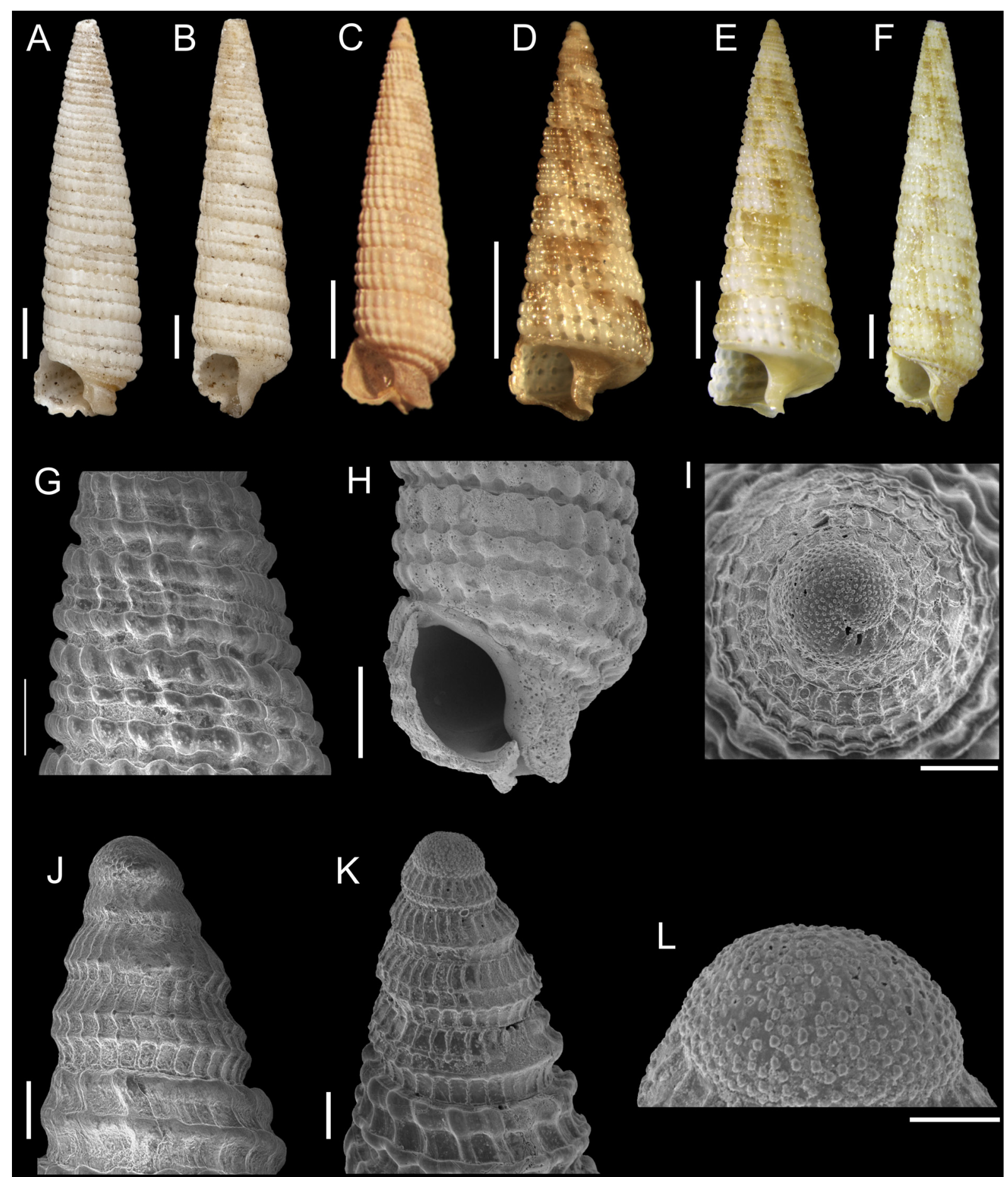

Fig. 90. Latitriphora albida (A. Adams, 1854). A. Syntype, NHM 196563. B. Syntype, NHM 196564. C. MNRJ 18625*, $5.12 \mathrm{~mm}$. D. MNRJ 31525*, $3.43 \mathrm{~mm}$. E. MNRJ 34825*, $5.17 \mathrm{~mm}$. F. MNRJ 33123*, $9.08 \mathrm{~mm}$. G, J. Same shell as E. H. Same shell as C. I, K-L. Same shell as D. Scale bars: A-F = $1 \mathrm{~mm}$; $\mathrm{G}=200 \mu \mathrm{m} ; \mathrm{H}=500 \mu \mathrm{m} ; \mathrm{I}-\mathrm{K}=100 \mu \mathrm{m} ; \mathrm{L}=50 \mu \mathrm{m}$. Photo credits A-B: Andreia Salvador (NHM). 


\section{Material examined}

BRAZIL - North Brazil • 1 spec.; REVIZEE-Norte III st. 150; UFMA* • 3 specs; REVIZEE-Norte III st. 176; UFMA*. - Rio Grande do Norte • 1 spec.; BPot 1-MR25; MNRJ 31518* • 3 specs; BPot 1-MR32; MNRJ 31519*• 1 spec.; BPot 1-MR42; MNRJ 31520*•1 spec.; BPot 1-MR43; MNRJ 31521* - 1 spec.; BPot 2-MR41; MNRJ 31522* • 1 spec.; BPot 2-MR42; MNRJ 31523*• 1 spec.; BPot 2-MR44; MNRJ 31524* • 1 spec.; BPot 2-MR45; MNRJ 31525*. - Fernando de Noronha Archipelago • 2 specs; Porto; depth 6 m; 20 Jul. 1999; P. Souza and L. Simone leg.; MZSP 31996. - Sergipe • 1 spec.; Petro/ UFS st. 18.1; UFS. - Bahia • 1 spec.; Canavieiras; Apr. 2011; MNRJ 33123* • 1 spec.; REVIZEECentral C5-12R; IBUFRJ 12112. - Espírito Santo • 1 spec.; 1940'26" S, 39³6'19" W; depth 40 m; 2 Dec. 2011; OC. Ship Seward Johnson leg.; MNRJ 34825*. - Campos Basin (Espírito Santo/Rio de Janeiro) • 1 spec.; REVIZEE-Central C1-VV21; MNRJ 33796* 1 spec.; HAB 17-I1; MNRJ 18625*.

MEXICO • 1 spec.; Yucatan; depth 107 m; BMSM 67512.

UNITED STATES OF AMERICA - Florida - 1 spec.; Deerfield Beach, Brower County; depth 3-4 m; Jul. 1998; P. Souza leg.; MZSP 41486 • 1 spec.; off Cristal River, Citrus County; BMSM 107189 • 1 spec.; off Cristal River, Citrus County; 55 m; BMSM 107194.

Monophorus olivaceus (Dall, 1889)

Fig. 91

Triforis decorata var. olivacea Dall, 1889: 244.

Triphora ornata auct. non Deshayes, 1832. - Olsson \& McGinty 1958: 13. - Warmke \& Abbott 1962: 76, pl. 13 fig. i. — Houbrick 1968: 14. — Rios 1970: 45; 1975: 51, pl. 13 fig. 189; 1985: 161, pl. 53 fig. 763; 1994: 95, pl. 31 fig. 376; 2009: 173. — Kobluk \& Lysenko 1986: 660. — Robinson \& Montoya 1987: 384. — De Jong \& Coomans 1988: 50. — Absalão 1989: 3. — Díaz 1994: 33. — Merlano \& Hegedus 1994: 149, pl. 46 fig. 527. — Paranaguá et al. 1999: 62. — Barros et al. 2002: 31. - Sevilla et al. 2003: 342. — Absalão \& Pimenta 2005: 29, fig. 64. — Absalão et al. 2006: 238. — Gomes et al. 2006: 187. — Daccarett \& Bossio 2011: 92, fig. 421.

Triphora (Cosmotriphora) ornata auct. non Deshayes, 1832 - Odé 1989: 110.

Triphora sp. 1 - Leal 1991: 122.

Monophorus olivaceus - Rolán \& Fernández-Garcés 1994: 17, figs 1-3, 6, 8, 30 MO; 2007: 23, pl. 4 figs 23-27; 2008: 87, fig. 4 b-f, h-k; 2015: 54, pl. 4, fig. h. — Redfern 2001: 67, pl. 33 fig. 284; 2013: 130, fig. 369. - Espinosa \& Ortea 2001: 20. — Lee 2009: 90. — Garcia \& Lee 2011. — Zhang 2011: 101, fig. 301. — Espinosa et al. 2012: 257. — García \& Capote 2013: 29. — Fernandes et al. 2013: 13, figs 13, 24, 34. - Lamy \& Pointier 2018: 287, pl. 92 fig. 6a-b. - Fernandes \& Pimenta 2019a: 24, figs 2f, 14-18.

Cosmotriphora ornata - Tunnell et al. 2010: 204. — Gracia et al. 2013: 383.

\section{Material examined}

BRAZIL - Amapá • 2 specs; Cabo Orange; depth 103 m; Nov. 1968; OC. Ship Almirante Saldanha leg.; MORG 14450 • 2 specs; AMASSEDS st. 4134; MORG 42254 • 1 spec.; off Amapá; depth 43 m; 17 Apr. 1968; OC. Ship Almirante Saldanha leg.; MORG 19529. - Pará • 1 spec.; off Caviana; depth 78-80 m; Mar. 1968; OC. Ship Almirante Saldanha leg.; MORG 15949 • 2 specs; off Caviana; depth 78-80 m; Mar. 1968; OC. Ship Almirante Saldanha leg.; MORG 19447 • 1 spec.; GEOMAR II st. 99; MORG 15768 - 2 specs; off Salinópolis; 0047' N, 46² $40^{\prime}$ W; 50 m; 26 Apr. 1968; OC. Ship Almirante Saldanha leg.;

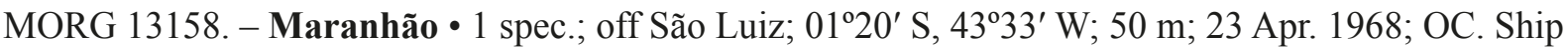
Almirante Saldanha leg.; MORG 13122 • 2 specs; 0149'45" S, 4255'35" W; 22 Nov. 2008; OC. Ship 
Amorim do Valle leg.; MZSP 92850. - Piauí • 4 specs; $02^{\circ} 10^{\prime} \mathrm{S}, 41^{\circ} 21^{\prime} \mathrm{W}$; depth 63 m; 30 Oct. 1967;

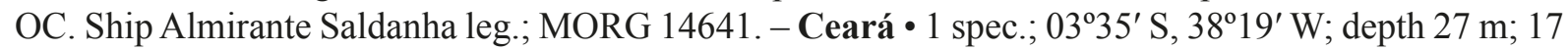
Apr. 1968; OC. Ship Almirante Saldanha leg.; MORG 14977 • 1 spec.; off Fortaleza; UFC $191 \bullet 1$ spec.; off Icapuí; Dec. 2000; MNRJ 32588*. - Rio Grande do Norte • 1 spec.; BPot 1-MR34; MNRJ 31548*
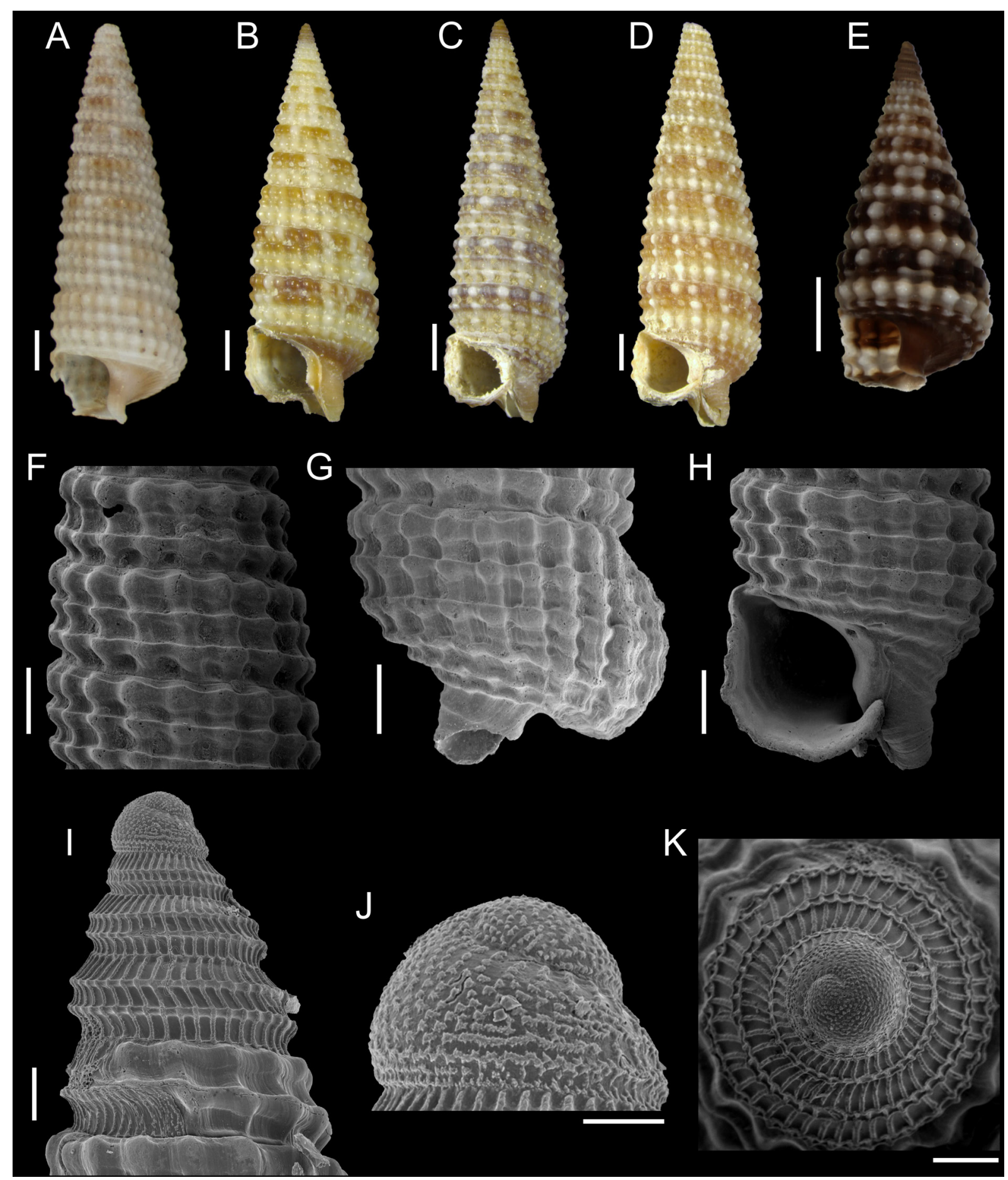

Fig. 91. Monophorus olivaceus (Dall, 1889). A. Lectotype, MCZ 7379. B. MNRJ 32550*, $9.90 \mathrm{~mm}$. C. MNRJ 32925*, $8.66 \mathrm{~mm}$. D. MNRJ 32990*, $11.05 \mathrm{~mm}$. E. MNRJ 18741*, $4.74 \mathrm{~mm}$. F-H. MNRJ 32075*. I-K. MNRJ 17988*. Scale bars: A-E = $1 \mathrm{~mm} ; \mathrm{F}-\mathrm{H}=500 \mu \mathrm{m}$; I, K = $100 \mu \mathrm{m} ; \mathrm{J}=50 \mu \mathrm{m}$. 
FERNANDES M.R. \& PIMENTA A.D., Update of Triphoridae from Brazil

- 8 specs; BPot 1-MR41; MNRJ 31549* • 15 specs; BPot 1-MR42; MNRJ 31550* • 4 specs; BPot 1-MR43; MNRJ 31551*• 6 specs; BPot 1-MR44; MNRJ 31552* • 5 specs; BPot 1-MR45; MNRJ $31553 *$ - 2 specs; BPot 2-MR32; MNRJ 31554* 3 specs; BPot 2-MR42; MNRJ 31555* - 21 specs; BPot 2-MR44; MNRJ 31556* • 2 specs; BPot 2-MR45; MNRJ 31557* • 1 spec.; Natal; MZSP 86297. Fernando de Noronha Archipelago 1 spec.; Ressurreta; depth 12 m; 17-18 Jun. 2000; P.M.S. Costa leg.; MNRJ 11347* • 1 spec.; Ressurreta; depth 12 m; 17-18 Jun. 2000; P.M.S. Costa leg.; MNRJ 14772* - 1 spec.; Buraco do Inferno; depth 12-18 m; 19 Jun. 2000; P.M.S. Costa leg.; MNRJ 14761* • 1 spec.; Praia do Cachorro; depth 10 m; 10 Jul. 1999; MNRJ 33799* • 1 spec.; Cabeço da Sapata; depth 40 m; 5 Jul. 1985; M. Cabeda leg.; MORG 24604 1 spec.; canal between Ilha do Meio and Ilha Rasa; depth 10 m; 21 Jul. 1999; L.R.L. Simone and P. Souza leg.; MZSP 30997 • 1 spec.; Jan. 1979; MORG 20633. Paraíba • 2 specs; 06 $59^{\prime} 01^{\prime \prime}$ S, 3445'12" W; depth 20 m; 7 Mar. 2006; P. Riul leg.; UEPB. - Alagoas • 1 spec.; Jaraguá, Maceió; MNRJ 18606* • 6 specs; Jaraguá, Maceió; MORG 33733. - Sergipe • 2 specs; Petro/UFS st. E5-A1; with soft part preservation; UFS • 2 specs; Petro/UFS st. E6-A1; UFS • 1 spec.; Petro/UFS st. 18.1; UFS. - Bahia • 9 specs; Salvador, Itapuã; MNRJ 41468* • 8 specs; Salvador, Itapuã; MORG 16596 • 7 specs; Salvador, Itapuã; MORG 33744 • 1 spec.; Salvador, Itapuã; MZSP 33740 • 1 spec.; Itapuã, Salvador; MZSP 33765 • 1 spec.; Salvador, Itapuã; MZSP 133317 • $1 \mathrm{spec}$.; Salvador, Praia da Pituba; FLMNH 361671 • 1 spec.; Salvador; MZSP 64886 • 1 spec.; 1327'43" S, 3849'27" W;

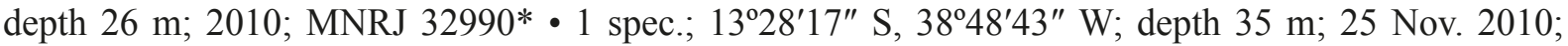
MNRJ 31032* • 1 spec.; REVIZEE-Central C5-4R; IBUFRJ 12286 • 1 spec.; REVIZEE-Central C1C76; IBUFRJ 9173 • 1 spec.; REVIZEE-Central C5-7R; IBUFRJ $12080 \bullet 1$ spec.; REVIZEE-Central C5-13R; IBUFRJ 19574 • 1 spec.; Belmonte; 21 Jul. 2008; MNRJ 32925* • 1 spec.; off Belmonte; depth 48 m; Nov. 1968; OC. Ship Almirante Saldanha leg.; MORG $13792 \cdot 1$ spec.; Minerva Bank; $17^{\circ} 06^{\prime}$ S, 37³8' W; depth 120 m; Aug. 2012; MZSP 110921 - 2 specs; Parcel Paredes, Abrolhos; Jan. 1985; MORG 23256 • 1 spec.; JOPS st. 3235; MNRJ 33814*. - Espírito Santo • 1 spec.; REVIZEE-Central C1-C65; IBUFRJ 12885 • 1 spec.; REVIZEE-Central C1-VV38; IBUFRJ $19618 \bullet 1 \mathrm{spec}$;; $19^{\circ} 25^{\prime}$ S, $39^{\circ} 22^{\prime} \mathrm{W}$; depth $55 \mathrm{~m}$; Oct. 2003; MNRJ 30715* 1 spec.; $19^{\circ} 25^{\prime} \mathrm{S}, 39^{\circ} 22^{\prime} \mathrm{W}$; depth $55 \mathrm{~m}$; Oct. 2003; MNRJ 30762* • 2 specs; $19^{\circ} 25^{\prime} 05^{\prime \prime} \mathrm{S}, 39^{\circ} 15^{\prime} 54^{\prime \prime} \mathrm{W}$; depth $65 \mathrm{~m}$; Oct. 2003; MNRJ 30703* • 2 specs; $19^{\circ} 25^{\prime} 05^{\prime \prime} \mathrm{S}, 39^{\circ} 15^{\prime} 54^{\prime \prime} \mathrm{W}$; depth 65 m; Oct. 2003; MNRJ 30767* • 1 spec.; REVIZEE-Central C1VV24; IBUFRJ 19475 • 5 specs; 20¹8' S, 40²14' W; Mar. 1993; V. Abud leg.; MORG 40033 • 2 specs; off Conceição da Barra; depth 60-80 m; Aug. 2006; C. Lyra leg.; MZSP 69565 • 3 specs; Vitória, Praia de Camburi; 19 Mar. 1993; IBUFRJ 6006 • 1 spec.; Ilha Escalvada, Guarapari; BMSM 45679 • 1 spec.; Ilha Escalvada, Guarapari; depth 25-30 m; May 1998; A. Bodart leg.; MZSP 53508 • 1 spec.; Ilha Escalvada, Guarapari; J. Coltro leg.; MZSP 91140 • 1 spec.; Guarapari canal; Apr. 1992; MZSP 78376 •

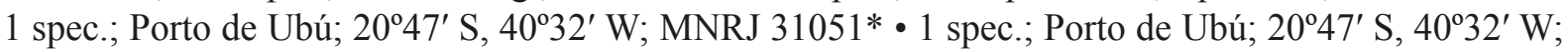
MNRJ 31062* • 1 spec.; Porto de Ubú; 2047' S, 40³2' W; MNRJ 31064* • 5 specs; Porto de Ubú; $20^{\circ} 47^{\prime} \mathrm{S}, 40^{\circ} 32^{\prime} \mathrm{W}$; MNRJ 32416* 5 specs; Piúma; 1993; IBUFRJ 8590. - Campos Basin (Espírito Santo/Rio de Janeiro) 1 spec.; REVIZEE-Central C1-D1-2; IBUFRJ $19529 \bullet 1 \mathrm{spec}$.; $20^{\circ} 42^{\prime} \mathrm{S}, 40^{\circ} 06^{\prime} \mathrm{W}$; 27 Aug. 1979; OC. Ship Almirante Câmara leg.; IBUFRJ 19550 • 2 specs; REVIZEE-Central C1-VV22; IBUFRJ $19569 \bullet 1$ spec.; $22^{\circ} 42^{\prime}$ S, 4040' W; depth 5-10 m; 20 Dec. 2007; MNRJ 17917*• 1 spec.; HAB 13-I2; MNRJ 17987* • 1 spec.; HAB 13-H3; MNRJ 17988* • 1 spec.; HAB 11-G3; MNRJ 17989* • 1 spec.; HAB 16-H3; MNRJ 18366* • 1 spec.; $22^{\circ} 42^{\prime}$ S, $40^{\circ} 40^{\prime}$ W; depth 12 m; Oct. 2005; MNRJ 32620* - 3 specs; $22^{\circ} 42^{\prime} \mathrm{S}, 40^{\circ} 40^{\prime} \mathrm{W}$; 2006; MNRJ $18741^{*}$ - 2 specs; $23^{\circ} 09^{\prime} 00^{\prime \prime} \mathrm{S}, 41^{\circ} 02^{\prime} 06^{\prime \prime} \mathrm{W}$; Oct. 2008; MNRJ 32075* • 1 spec.; $23^{\circ} 05^{\prime} \mathrm{S}, 40^{\circ} 58^{\prime} \mathrm{W}$; depth $100 \mathrm{~m}$; 2004 MNRJ $32550^{*} \bullet 1$ spec.; $23^{\circ} 05^{\prime} \mathrm{S}$, $40^{\circ} 58^{\prime} \mathrm{W}$; depth $100 \mathrm{~m}$; 2004; MNRJ 32628* • 1 spec.; $23^{\circ}{ }^{\circ} 8^{\prime} \mathrm{S}, 41^{\circ} 14^{\prime} \mathrm{W}$; depth $120 \mathrm{~m}$; 20 Nov. 2004; OC. Ship Almirante Câmara leg.; MORG 50199. - Rio de Janeiro • 1 spec.; Búzios, Praia da Ferradura; MNRJ 18597* 3 specs; Búzios, Praia de Manguinhos; Apr. 1985; L. Tostes leg.; MNRJ 34112* • 1 spec.; Cabo Frio, Praia das Conchas; Jan. 1979; L. Tostes leg.; MNRJ 34111* • 3 specs; Cabo Frio, Praia das Conchas; 23 Apr. 2005; V. Padula and F. Santos leg.; MNRJ 33004* • 1 spec.; Cabo Frio; 17 Feb. 1970; J. Colella leg.; MZSP 57206 • 1 spec.; Cabo Frio, Praia do Forte; Jan. 1988; P.M.S. Costa leg.; MNRJ 20386* • 2 specs; Cabo Frio, Praia do Forte; 16 Jul. 1988; P.M.S. Costa leg.; MNRJ 20508*• 
1 spec.; Arraial do Cabo, Prainha; depth 3 m; Feb. 1984; M. Sá and G. Nunan leg.; MNRJ 17921*. - São Paulo • 1 worn spec.; Ilha da Queimada Pequena, Itanhaém; depth 0-12 m; 28 Feb. 2007; MZSP 84998. The latter record must be regarded with caution, because it considerably extends the geographic range of M. olivaceus; more specimens are needed to confirm its presence in São Paulo State.

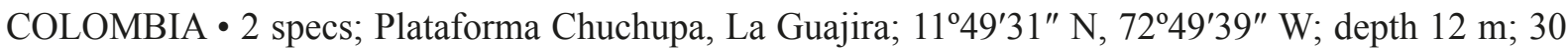
Oct. 2004; J. Reyes and A. Clavijo leg.; INV MOL7919 • 1 spec.; Plataforma Chuchupa, La Guajira; $11^{\circ} 47^{\prime} 15^{\prime \prime}$ N, 72 $46^{\prime} 50^{\prime \prime}$ W; depth 9 m; 3 Nov. 2004; J. Reyes and A. Clavijo leg.; INV MOL7918 •

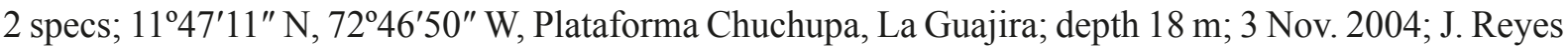
and A. Clavijo leg.; INV MOL7921 • 1 spec.; Archipiélagos Coralinos; 09²46'26" N, 76 13'54" W; depth 117 m; 1 May 2005; A. Clavijo leg.; INV MOL6536.

CURAÇAO • 1 spec.; Santa Marta Bay; depth 1 m; Jul. 1992; BMSM 67464.

GRENADA • 1 spec.; $12^{\circ} 01^{\prime} 04^{\prime \prime}$ N, 61 $61^{\circ} 45^{\prime} 40^{\prime \prime}$ W, Belmont, Saint George; depth 3-6 m; 7 Oct. 2012; MZSP 109728.

UNITED STATES OF AMERICA - Florida • 1 spec.; Deerfield Beach, Brower County; depth 3-5 m; Jun. 1998; P. Souza leg.; MZSP 133325 • 1 spec.; Pickles reef, Key Largo, Florida Keys; depth 3-5 m; BMSM 45686 • 1 spec.; Egmont Key, St. Petersburg; BMSM 67420 • 1 spec.; off Cristal River, Citrus County; BMSM 67459.

Nanaphora verbernei (Moolenbeek \& Faber, 1989)

Triphora verbernei Moolenbeek \& Faber, 1989: 77, figs 6-8.

Cheirodonta verbernei - Rolán \& Fernández-Garcés 1994: 20, figs 17-18, 22, 30 CV. — Zhang 2011: 99, fig. 288.

Cosmotriphora verbernei - Rolán \& Fernández-Garcés 2007: 20, pl. 1 figs 17-18.

Nanaphora verbernei - Fernandes \& Pimenta 2015: 500, fig. 4; 2019a: 30, figs 2g, 19-20. — Rolán \& Fernández-Garcés 2015: 53, fig. 4w.

\section{Material examined}

BRAZIL - Rio Grande do Norte • 2 specs; BPot 1-MR23; MNRJ 31545*. - Alagoas • 1 spec.; Barra de São Miguel; 0950'09" S, 3553'05" W; depth 0-3 m; 1 Dec. 2018; M.R. Fernandes and L.S. Souza leg.; with soft part preservation; MNRJ 60029 • 2 specs; Petro/MAR st. 19; UFS. - Bahia • 1 spec.; Salvador, Itapuã; 17 jul. 1967; E. Rios leg.; MORG 52624. - Espírito Santo • 1 spec.; $20^{\circ} 18^{\prime}$ S, 40 $14^{\prime}$ W; Mar. 1993; V. Abud leg.; MORG 40032. - São Paulo • 1 spec.; Ubatuba; FLMNH 363884 • 1 spec.; Ubatuba, Enseada do Flamengo; W. Narchi leg.; 7 Jan. 1956; MNHN-Mo 7640* • 1 spec.; São Sebastião, Praia do Guaecá; 2349'14" S, 45²7'45" W; 9 Aug. 2011; MZSP 133339 • 1 spec.; Guarujá; M.A. Cardoso leg.; MZSP 17890.

Nototriphora decorata (C.B. Adams, 1850)

Fig. 92

Cerithium decoratum C.B. Adams, 1850: 117.

Triphoris variegatus A. Adams, 1854: 277.

Triforis arthuri Jousseaume, 1884: 221.

Triforis decorata - Dall 1892: 265. 
Cerithium decoratum - Clench \& Turner 1950: 272, pl. 38 fig. 2.

Triphora decorata - Olsson \& McGinty 1958: 13. — Porta \& Porta 1960: 42. - Rice \& Kornicker 1962: 372, pl. 4 fig. 4. — Rios 1970: 45; 1975: 50, pl. 13 fig. 186; 1985: 160, pl. 53 fig. 760; 1994: 94, pl. 31 fig. 373; 2009: 172. — Abbott 1974: 111, fig. 1133. — De Jong \& Coomans 1988: 51.
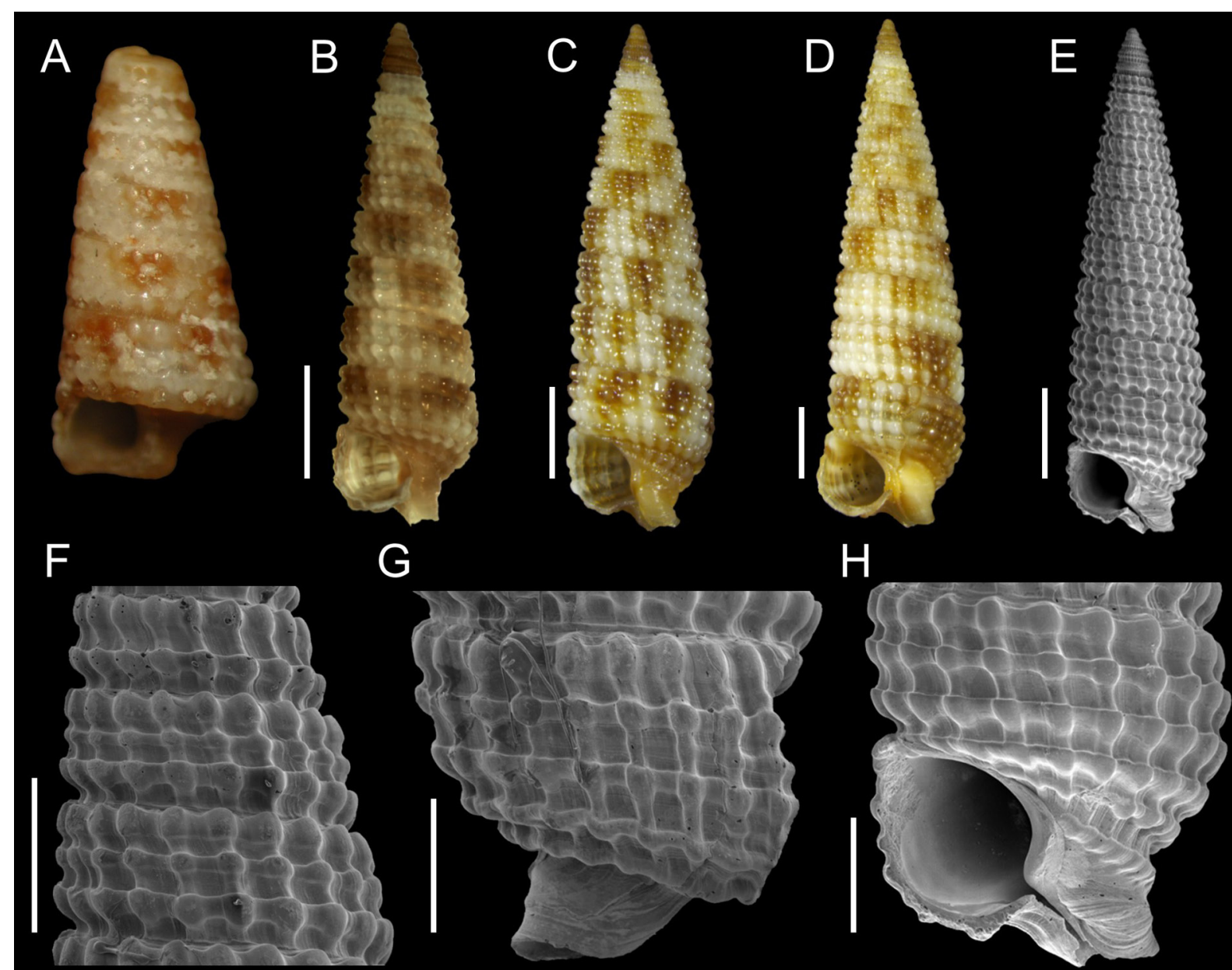

G

$\mathrm{H}$
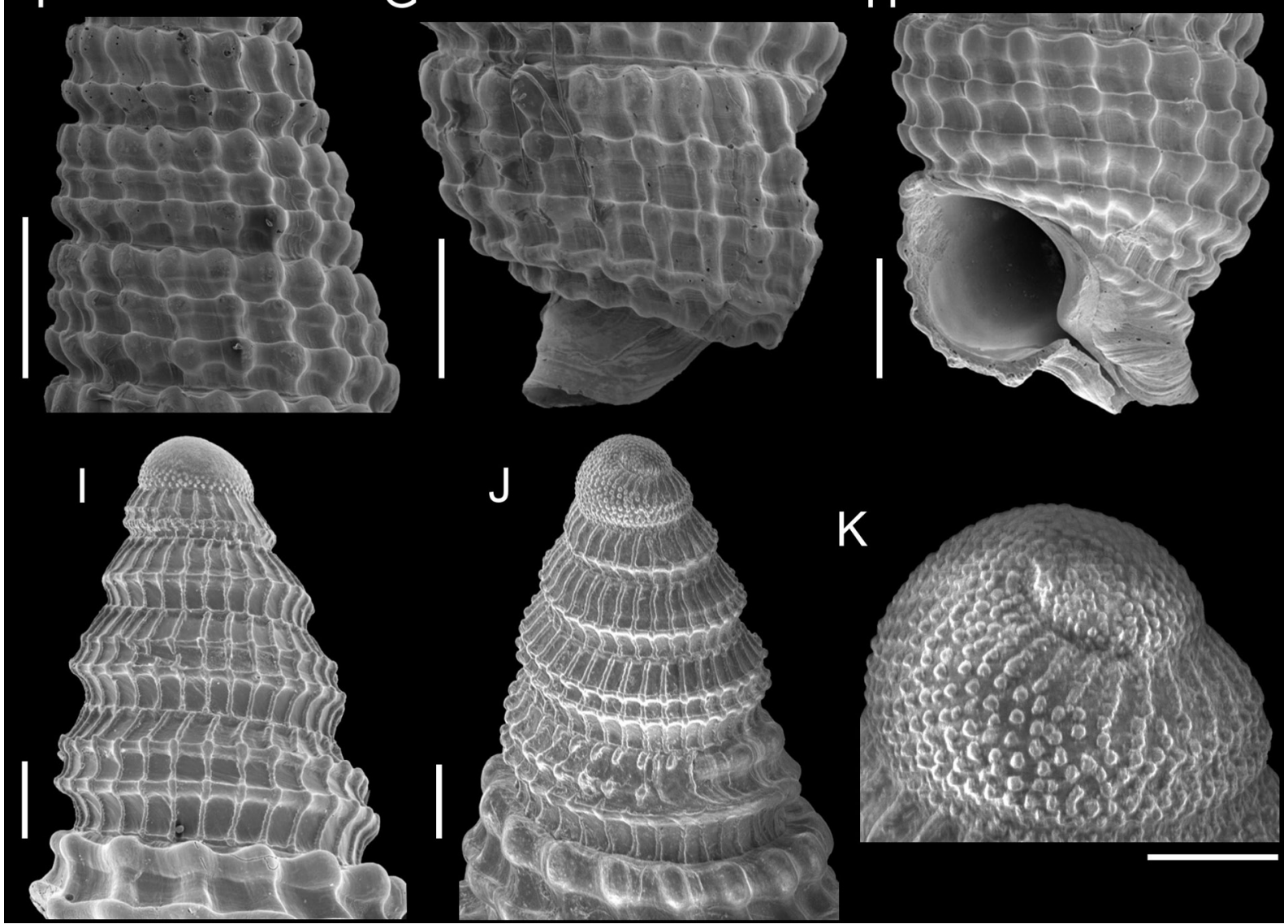

Fig. 92. Nototriphora decorata (C.B. Adams, 1850). A. Lectotype, MCZ 186178. B. MNRJ 18410*, $4.47 \mathrm{~mm}$. C.MNRJ 18954*, $5.53 \mathrm{~mm}$. D. MNRJ 34109*, $7.12 \mathrm{~mm}$. E. MNRJ 17990*, $5.61 \mathrm{~mm}$. F-H. Same shell as E. I. MNRJ 18398*. J-K. Same shell as C. Scale bars: B-E $=1 \mathrm{~mm} ; \mathrm{F}-\mathrm{H}=500 \mu \mathrm{m}$; I-J = $100 \mu \mathrm{m} ; \mathrm{K}=50 \mu \mathrm{m}$. 
—Absalão 1989: 3. — Leal 1991: 122, pl. 16 figs j-k. — Díaz 1994: 33. — Hess \& Abbott 1994: 147. - Merlano \& Hegedus 1994: 148, pl. 46 fig. 521. — Coelho-Filho 2004: 25. - Absalão et al. 2006: 238. — Gomes et al. 2006: 187. — Gutiérrez-Salcedo et al. 2007: 316. — Santos et al. 2007: 226. — Daccarett \& Bossio 2011: 91, fig. 416.

Triphora (Cosmotriphora) decorata - Odé 1989: 110, fig. 5.

Nototriphora decorata - Rolán \& Fernández-Garcés 1994: 19, figs 10, 14, 16, 30 ND; 2007: 24, pl. 5 figs 1-5; 2015: 54, pl. 4 fig. d. — Redfern 2001: 68, pl. 33 fig. 285; 2013: 130, fig. 370. — Espinosa \& Ortea 2001: 20. — Dowgiallo 2004: 93. — Lee 2009: 91. — Jensen \& Pearce 2009: 129. — Tunnell et al. 2010: 206. — Zhang 2011: 101, fig. 302. — Espinosa et al. 2012: 257. — García \& Capote 2012: 22; 2013: 29. - Fernandes et al. 2013: 14, figs 14, 25, 35. — Gracia et al. 2013: 383. Longo et al. 2014: 4, fig. 4b. — Lamy \& Pointier 2018: 287, pl. 92 figs 7a-b. - Fernandes \& Segadilha 2019: 134, figs 4a, g. — Fernandes \& Pimenta 2019a: 33, figs 2h, 21-23.

Triphora ecorate [sic] - Reyes et al. 2007: 383.

\section{Material examined}

BRAZIL - North Brazil • 2 specs; REVIZEE-Norte III st. 150; UFMA* • 8 specs; REVIZEE-Norte III st. 176; UFMA* • 1 spec.; REVIZEE-Norte III st. 192; UFMA*• 1 spec.; REVIZEE-Norte III st. 211A; UFMA*. - Amapá - 2 specs; off Cabo Orange; depth 103 m; 29 Nov. 1968; OC. Ship Almirante Saldanha leg.; MORG 14449 • 9 specs; 0358'43" N, 49³3'24" W; 2001; MNRJ 32559* • 1 spec.; AMASSEDS st. 4134; MNRJ 34460*. - Pará • 1 spec.; off Salinópolis; depth 27 m; 26 Apr. 1968; OC. Ship Almirante Saldanha leg.; MORG 13692. - Rio Grande do Norte • 1 spec.; BPot 1-MR11; MNRJ 31558* • 2 specs; BPot 1-MR26; MNRJ 31559* • 2 specs; BPot 1-MR31; MNRJ 31560* • 15 specs; BPot 1-MR32; MNRJ 31561* • 12 specs; BPot 1-MR41; MNRJ 31562* • 36 specs; BPot 1-MR42; MNRJ 31563* • 20 specs; BPot 1-MR43; MNRJ 31564* • 11 specs; BPot 1-MR44; MNRJ 31565* • 14 specs; BPot 1-MR45; MNRJ 31566* • 2 specs; BPot 2-MR22; MNRJ 31567* • 9 specs; BPot 2-MR32; MNRJ 31568*• 1 spec.; BPot 2-MR33; MNRJ 31569* • 2 specs; BPot 2-MR34; MNRJ 31570* • 1 spec.; BPot 2-MR41; MNRJ 31571* • 13 specs; BPot 2-MR42; MNRJ 31572* • 24 specs; BPot 2-MR44; MNRJ 31573* • 15 specs; BPot 2-MR45; MNRJ 31574* • 1 spec.; 0444'11" S, 36 24'55" W; depth 425-450 m; 7 May 2011; MNRJ 35110*. - Fernando de Noronha Archipelago • 1 spec.; 0351' S, 3525' W; 1998; L.R.L. Simone leg.; MZSP 100283. - Paraíba • 1 spec.; 0706'59" S, 34²6'04" W; 14 Mar. 2006; P. Riul leg.; UEPB. - Alagoas • 3 specs; Maceió, Jaraguá; MNRJ 18608*• 35 specs; Maceió, Jaraguá; MORG 33732 • 1 spec.; Petro/MAR st. 21; UFS. - Sergipe • 1 spec.; Petro/ UFS st. E5-A2; with soft part preservation; UFS • 1 spec.; Petro/UFS st. E6-A1; UFS • 6 specs; Petro/ UFS st. 15.3; UFS • 15 specs; Petro/UFS st. 18.1; UFS. - Bahia • 2 specs; Salvador, Itapuã; 17 Jul. 1967; E. Rios leg.; MORG 13822 • 14 specs; Salvador, Itapuã; 17 Jul. 1967; E. Rios leg.; MORG 16374 • 21 specs; Salvador, Itapuã; 17 Jul. 1967; E. Rios leg.; MORG 33722 • 3 specs; Salvador, Itapuã; May 1974; L. Ferreira leg.; MORG 22048 • 1 spec.; Salvador, Itapuã; L. Tostes leg.; MNRJ 41721* • 6 specs; Salvador, Itapuã; MZSP 34321 • 1 spec.; Salvador, Itapuã; MZSP 133314 • 18 specs; Salvador; intertidal; Apr. 1981; G. Oliveira leg.; MNRJ 21356* • 30 specs; Salvador; intertidal; Apr. 1981; G. Oliveira leg.; MORG 31931 - 5 specs; Baía de Todos os Santos; Jun. 1997; MNRJ 34423* - 2 specs; 132' S, $38^{\circ} 48^{\prime} \mathrm{W}$; depth $30 \mathrm{~m}$; Sep. 2007; MNRJ 32613* • 1 spec.; 132ㅇ' $18^{\prime \prime} \mathrm{S}, 38^{\circ} 48^{\prime} 43^{\prime \prime} \mathrm{W}$; depth $35 \mathrm{~m}$; MNRJ $31031^{*} \bullet 5$ specs; $13^{\circ} 28^{\prime} 17^{\prime \prime}$ S, 38 $48^{\prime} 43^{\prime \prime}$ W; depth 35 m; MNRJ 32608* • 3 specs; $13^{\circ} 29^{\prime} 44^{\prime \prime}$ S, $38^{\circ} 48^{\prime} 19^{\prime \prime} \mathrm{W}$; depth 33 m; 25 Nov. 2010; MNRJ 32991* • 6 specs; 13³0'27" S, 3848'45" W; 24 Nov. 2007; MNRJ 32898* • 3 specs; off Camamú; depth 52 m; 11 Dec. 2002; MORG 45532 • 1 spec.; Cairu, Morro de São Paulo, Praia de Garapuá; depth 5 m; 2011; P. Coelho-Filho leg.; with soft part preservation; MZSP 100930 • 2 specs; Ilhéus; MNRJ 32370* • 1 spec.; off Canavieiras; Apr. 2011; MNRJ 32961* • 3 specs; REVIZEE-Central C5-7R; MNRJ 17919* • 3 specs; REVIZEE-Central C5-7R; IBUFRJ 14700 - 1 spec.; REVIZEE-Central C5-13R; IBUFRJ 11957 - 1 spec.; REVIZEE-Central C5-13R; IBUFRJ 13318 • 5 specs; REVIZEE-Central C5-13R; IBUFRJ 13319 • 1 spec.; REVIZEE-Central C1C66; IBUFRJ 9674 • 2 specs; Abrolhos; depth 5 m; L.C. Araujo leg.; Jul. 1972; MORG 18057 • 1 spec.; 
Abrolhos; Jan. 1985; MORG 52622. - Espírito Santo - 2 specs; REVIZEE-Central C1-VV31; IBUFRJ 11403 • 1 spec.; REVIZEE-Central C1-C65; IBUFRJ 9482 - 1 spec.; REVIZEE-Central C1C65; IBUFRJ 12893 • 1 spec.; REVIZEE-Central C1-C65; IBUFRJ $19462 \cdot 2$ specs; REVIZEE-Central C1-C65; MORG 33530 • 1 spec.; REVIZEE-Central C1-C64; IBUFRJ $9245 \cdot 15$ specs; REVIZEECentral C1-VV38I; BUFRJ 12894 • 4 specs; REVIZEE-Central C1-VV38I; BUFRJ 19610 • 3 specs;

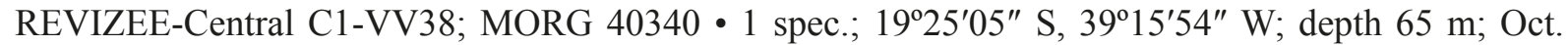

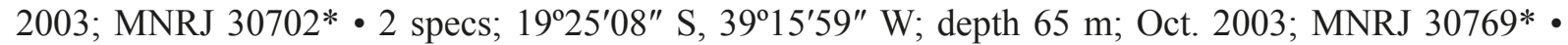
1 spec.; 19 $25^{\prime} 34^{\prime \prime} \mathrm{S}, 39^{\circ} 22^{\prime} 16^{\prime \prime} \mathrm{W}$; depth $42 \mathrm{~m}$; Oct. 2003; MNRJ 31164* • 1 spec.; 19 $26^{\prime} 33^{\prime \prime} \mathrm{S}$, $39^{\circ} 22^{\prime} 02^{\prime \prime} \mathrm{W}$; depth $50 \mathrm{~m}$; Oct. 2003; MNRJ 30714* • 2 specs; $19^{\circ} 40^{\prime 2} 26^{\prime \prime} \mathrm{S}, 39^{\circ} 36^{\prime} 19^{\prime \prime} \mathrm{W}$; depth $40 \mathrm{~m}$; 2 Dec. 2011; OC. Ship Seward Johnson leg.; MNRJ 34826* • 2 specs; REVIZEE-Central C1-VV24; IBUFRJ 19474 • 1 spec.; REVIZEE-Central C1-VV24; MORG 52254 • 1 spec.; $20^{\circ} 18^{\prime} \mathrm{S}, 40^{\circ} 14^{\prime} \mathrm{W}$; Mar. 1993; V. Abud leg.; MORG 39972 - 5 specs; 20¹8' S, 40¹4' W; Mar. 1993; V. Abud leg.; MORG 40026 • 1 spec.; Ilha Escalvada, Guarapari; depth 20-22 m; May 1994; A. Bodart leg.; CHL • 2 specs; Ilha Escalvada, Guarapari; 2012; W. Vieira leg.; MNRJ 34032* • 3 specs; Porto de Ubú; $20^{\circ} 47^{\prime}$ S, $40^{\circ} 32^{\prime}$ W; Nov. 2007; MNRJ 32411* • 1 spec.; Porto de Ubú; 20 47' S, 40³2' W; Mar. 2010; MNRJ 31048* • 1 spec.; Porto de Ubú; 2047' S, 40³2' W; Mar. 2010; MNRJ 31057* • 1 spec.; Porto de Ubú; 2047' S, 40³2' W; Mar. 2010; MNRJ 31079*• 1 spec.; Porto de Ubú; 2047' S, 40³2' W; Mar. 2010; MNRJ 31093* • 17 specs; Piúma; 1993; IBUFRJ 8574. - Vitória-Trindade Chain • 2 specs; Trindade Island; depth 10 m; Mar. 1986; MORG 24410. - Campos Basin (Espírito Santo/Rio de Janeiro) - 1 spec.; $21^{\circ} 17^{\prime}$ S, 40¹8' W; 26 Aug. 1979; OC. Ship Almirante Câmara leg.; IBUFRJ 7563 • 10 specs; REVIZEE-Central C1-VV21; IBUFRJ 12883 • 3 specs; REVIZEE-Central C1-VV16; IBUFRJ 12892 • 3 specs; 205' S, 40¹2' W; 26 Aug. 1979; OC. Ship Almirante Câmara leg.; IBUFRJ 19517 • 1 spec.; REVIZEE-Central C1-D1-2; IBUFRJ 19530 • 7 specs; REVIZEE-Central C1-D3; IBUFRJ 19582 • 2 specs; HAB 11-G4; MNRJ 17946* • 1 spec.; HAB 13-H3; MNRJ 17973* • 1 spec.; HAB 13-H1; MNRJ 17984* • 5 specs; HAB 13-I2; MNRJ 17990* • 1 spec.; HAB 16-B4; MNRJ 18369* 1 spec.; HAB 17-I3; MNRJ 18389* • 1 spec.; HAB 16-G4; MNRJ 18397* • 4 specs; HAB 16-G3; MNRJ 18398* - 15 specs; HAB 17-I2; MNRJ 18410* • 1 spec.; HAB 16-C4; MNRJ 18427* 5 specs; HAB 16-H3; MNRJ 18435* 1 spec.; HAB 16-H2; MNRJ 18436* • 2 specs; $22^{\circ} 42^{\prime}$ S, $40^{\circ} 40^{\prime} \mathrm{W}$; depth $110 \mathrm{~m}$; 2006; MNRJ $18752^{*} \cdot 2$ specs; $22^{\circ} 42^{\prime} \mathrm{S}, 40^{\circ} 40^{\prime} \mathrm{W}$; depth 5-10 m; MNRJ $18954^{*} \cdot 2$ specs; $23^{\circ} 02^{\prime} \mathrm{S}, 40^{\circ} 20^{\prime} \mathrm{W}$;

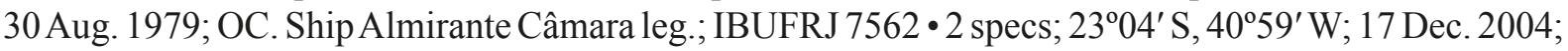
MNRJ 18968* - 2 specs; 22 $42^{\prime}$ S, 4040' W; depth 110 m; 19 Sep. 2003; MNRJ 30904* • 1 spec.; $23^{\circ} 09^{\prime} 00^{\prime \prime} \mathrm{S}, 41^{\circ} 02^{\prime} 06^{\prime \prime}$ W; Oct. 2008; MNRJ 32074* - 1 spec.; $22^{\circ} 42^{\prime} \mathrm{S}, 40^{\circ} 40^{\prime} \mathrm{W}$; depth $12 \mathrm{~m}$; Oct. 2005; MNRJ 32621* • 3 specs; REVIZEE-Central C1-VV22; MORG 40409 • 1 spec.; REVIZEECentral C1-VV21; MORG 52204. - Rio de Janeiro - 1 spec.; Porto do Açu, São João da Barra; $21^{\circ} 49^{\prime} 04^{\prime \prime}$ S, 41 $41^{\circ} 00^{\prime} 04^{\prime \prime}$ W; Jul. 2012; MZSP 111139 • 1 spec.; Rio das Ostras; $22^{\circ} 31^{\prime} 59^{\prime \prime}$ S, 41 ${ }^{\circ} 56^{\prime} 51^{\prime \prime}$ W; depth 3 m; 21 Sep. 2007; J.B. Mendonça leg.; MZSP 97209 • 2 specs; Búzios, Praia da Ferradura; MNRJ 18596* • 3 specs; Cabo Frio, Praia do Peró; Apr. 1979; L. Tostes leg.; MNRJ 34109* • 2 specs; Cabo Frio, Praia das Conchas; Jan. 1979; L. Tostes leg.; MNRJ 34110*•1 spec.; Ilha dos Porcos, Arraial do Cabo; depth 9 m; 17 Sep. 2009; P. Oristânio leg.; MZSP 92387 • 2 specs; Itaipú, Niterói; 1981; IBUFRJ 955 • 11 specs; Angra dos Reis, Praia da Figueira; 1998; C. Alvarenga leg.; IBUFRJ 13682 • 4 specs; Ilha Comprida, Angra dos Reis; RAP-BIG st. 19; UERJ 5744 • 1 spec.; Ilha da Murta, Angra dos Reis; RAP-BIG st. 20; UERJ 5848 - 2 specs; Ilha Itanhangá, Angra dos Reis; 22 59'23" S,

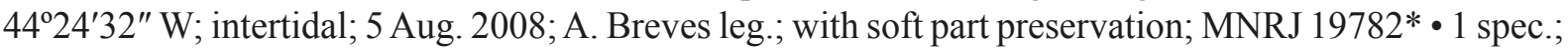

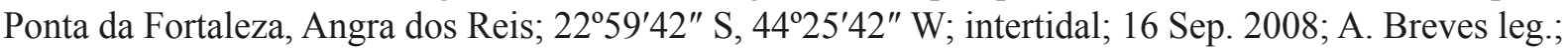
with soft part preservation; MNRJ 19786* • 3 specs; Ilha Peregrino, Angra dos Reis; 2301'31" S,

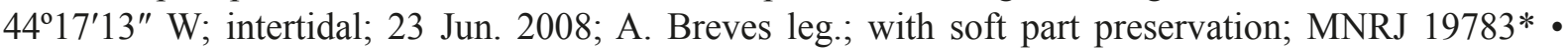

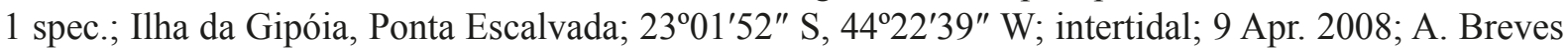
leg.; with soft part preservation; MNRJ 19788* • 13 specs; Ilha da Gipóia, Ponta Escalvada; RAP-BIG

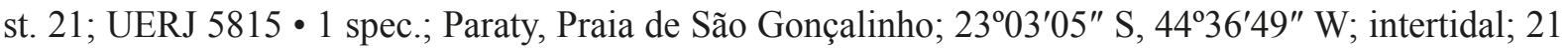
May 2008; A. Breves leg.; with soft part preservation; MNRJ 19787* • 7 specs; Ilha de Macacos, Angra 
dos Reis; RAP-BIG st. 30; UERJ 5559 - 2 specs; Laje do Coronel, Angra dos Reis; RAP-BIG st. 24; UERJ 4938 • 1 spec.; Ilha da Gipóia, Angra dos Reis; RAP-BIG st. 22; UERJ 7543 • 2 specs; Angra dos Reis, Ponta Grande; RAP-BIG st. 17; UERJ 7545 • 3 specs; Ilha Grande, Praia dos Morcegos; RAP-BIG st. 32; with soft part preservation; UERJ 5591 - 3 specs; Ilha Grande, Ponta do Guriri, Angra dos Reis; $23^{\circ} 10^{\prime} 24^{\prime \prime}$ S, 4405'33" W; intertidal; 19 Sep. 2009; A. Breves leg.; MNRJ 19784* • 1 spec.; Ilha Grande, Enseada do Abraão, Angra dos Reis; 18 Mar. 1979; MNRJ 17927* • 3 specs; Ilha Grande, Ponta da Enseada; RAP-BIG st. 31; UERJ 5181 • 3 specs; Ilha Grande, Ponta Longa; RAP-BIG st. 39; UERJ 7546 • 11 specs; Ilha Grande; RAP-BIG st. 40; UERJ 4331 3 specs; Ilha Grande, Enseada de Lopes Mendes; RAP-BIG st. 34; UERJ 5236 • 11 specs; Ilha Grande, Enseada Dois Rios; 20 Nov. 1996; UERJ 7544 • 1 spec.; Ilha Grande, Ponta Alta de Parnaioca; RAP-BIG st. 36; UERJ 4919 • 2 specs; Ilha Rapada, Paraty; RAP-BIG st. 12; UERJ 5632 - 5 specs; Paraty, Praia Vermelha; RAP-BIG st. 10; UERJ 3792 • 1 spec.; Paraty, Praia da Sapeca; J. Tarasconi leg.; 10 Feb. 2004; MORG 46653 • 2 specs; Ilha Jorge

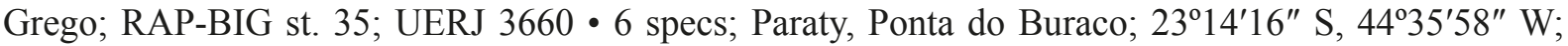
depth 4.5 m; 14 Nov. 2003; UERJ 5891 • 1 spec.; Paraty, Cajaíba, Praia Grande; RAP-BIG st. 3; UERJ 7542 - 1 spec.; Paraty, Ponta de Juatinga; RAP-BIG st. 1, UERJ 3741. - São Paulo • 3 specs; Ubatuba, Praia da Enseada; Jul. 1958; C. Garcia leg.; MNHN-Mo 3796* • 2 specs; Ubatuba, Enseada do Flamengo; 24-25 Jun. 1956; C. Jesus and P. Cardoso leg.; MNRJ 55815* • 3 specs; Ubatuba, Enseada do Flamengo; 24-25 Jun. 1956; C. Jesus and P. Cardoso leg.; MZSP 24653 • 2 specs; Ubatuba, Enseada do Flamengo; 24-25 Jun. 1956; C. Jesus and P. Cardoso leg.; MNHN-Mo 3781* 2 specs; Ubatuba, Enseada do Flamengo; 7 Jan. 1956; W. Narchi leg.; MNHN-Mo 7640* • 1 spec.; Ubatuba, Itaguá; Oct. 1991;

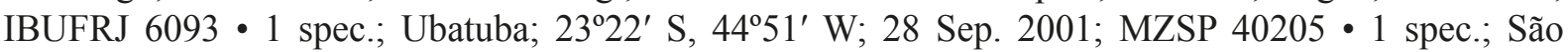

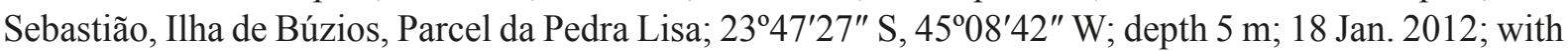
soft part preservation; MZSP 105975 - 5 specs; São Sebastião, Ilha de Búzios; 24 Oct. 2012; A.P. Dornellas leg.; MZSP 109516 • 1 spec.; São Sebastião, Praia do Guaecá; 2349'14" S, 45²7'45" W; 9 Aug. 2011; MZSP 118847 • 2 specs; São Sebastião; MZSP 64363 • 1 spec.; Guarujá; M.A. Cardoso leg.; MZSP 133309. - Santa Catarina • 1 spec.; Florianópolis, Barra da Lagoa; 16 Feb. 1986; G. Nunan leg.; MNRJ 33314*.

COLOMBIA - 1 spec.; La Guajira, Plataforma Chuchupa; $11^{\circ} 47^{\prime} 15^{\prime \prime} \mathrm{N}, 72^{\circ} 46^{\prime} 50^{\prime \prime}$ W; depth $18 \mathrm{~m}$; J. Reyes and A. Clavijo leg.; 3 Nov. 2004; INV MOL7920 • 1 spec.; Tayrona, Bahía de Nenguange; $11^{\circ} 19^{\prime} 16^{\prime \prime}$ N, 740'일 W; depth 40-50 m; 1 Apr. 1980; M. Aubad and B. Echeverry leg.; INV MOL705

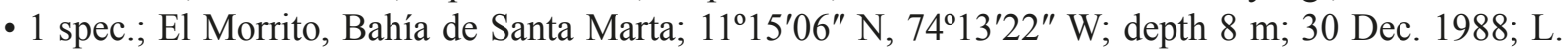
Escobar leg.; INV MOL969.

CURAÇAO • 1 spec.; Newport; 1205' N, 6849' W; depth 5-15 m; Mar. 2004; MZSP 116109.

UNITED STATES OF AMERICA - Florida • 1 spec.; Deerfield Beach, Brower County; depth 3-5 m;

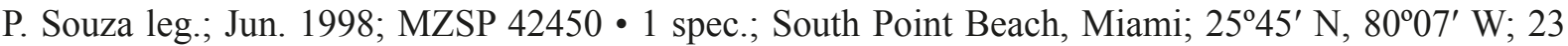
Jun. 2016; M.R. Fernandes leg.; with soft part preservation; MNRJ 35953* • 1 spec.; Little Torch Key; 15 Jul. 1977; M. Teskey leg.; FLMNH 507938.

Sagenotriphora osclausum (Rolán \& Fernández-Garcés, 1995) Fig. 93

Triphora osclausum Rolán \& Fernández-Garcés, 1995: 15, figs 36-38.

Triphora osclausum - Rolán \& Fernández-Garcés 2007: 24, pl. 5 figs 26-27. — Redfern 2001: 69, pl. 33 fig. 288. — Lamy \& Pointier 2018: 289, pl. 92 fig. 10.

Sagenotriphora osclausum - Rolán \& Fernández-Garcés 2008: 132, fig. 22 A-I. — Lee 2009: 91. —Zhang 2011: 101, fig. 304. — Redfern 2013: 130, fig. 371. — Fernandes \& Pimenta 2019a: 37, figs 2i, 24. 


\section{Material examined}

BRAZIL - North Brazil • 7 specs; REVIZEE-Norte III st. 176; UFMA*. - Maranhão • 1 spec.; Parcel Manuel Luís; 6 Apr. 1994; UFMA*. - Rio Grande do Norte • 6 specs; BPot 1-MR32; MNRJ 31575*

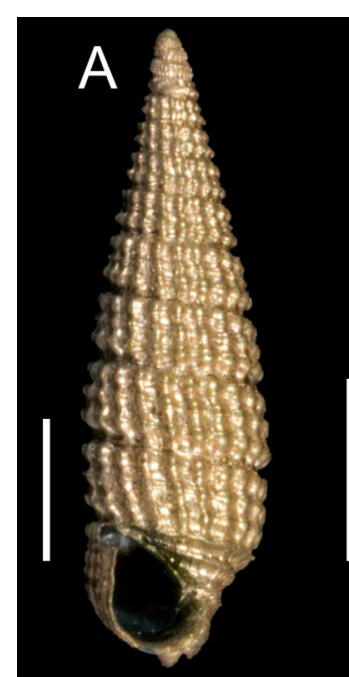

$\mathrm{F}$

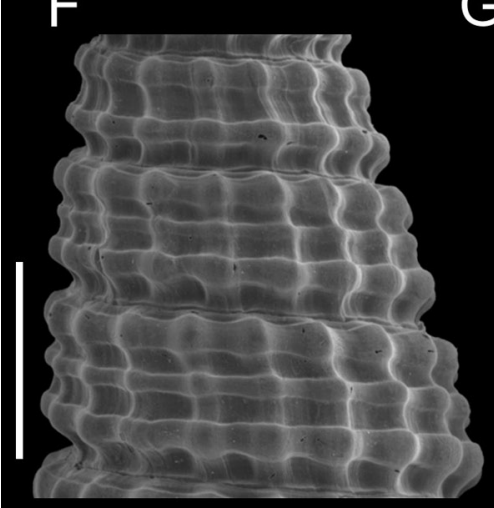

G
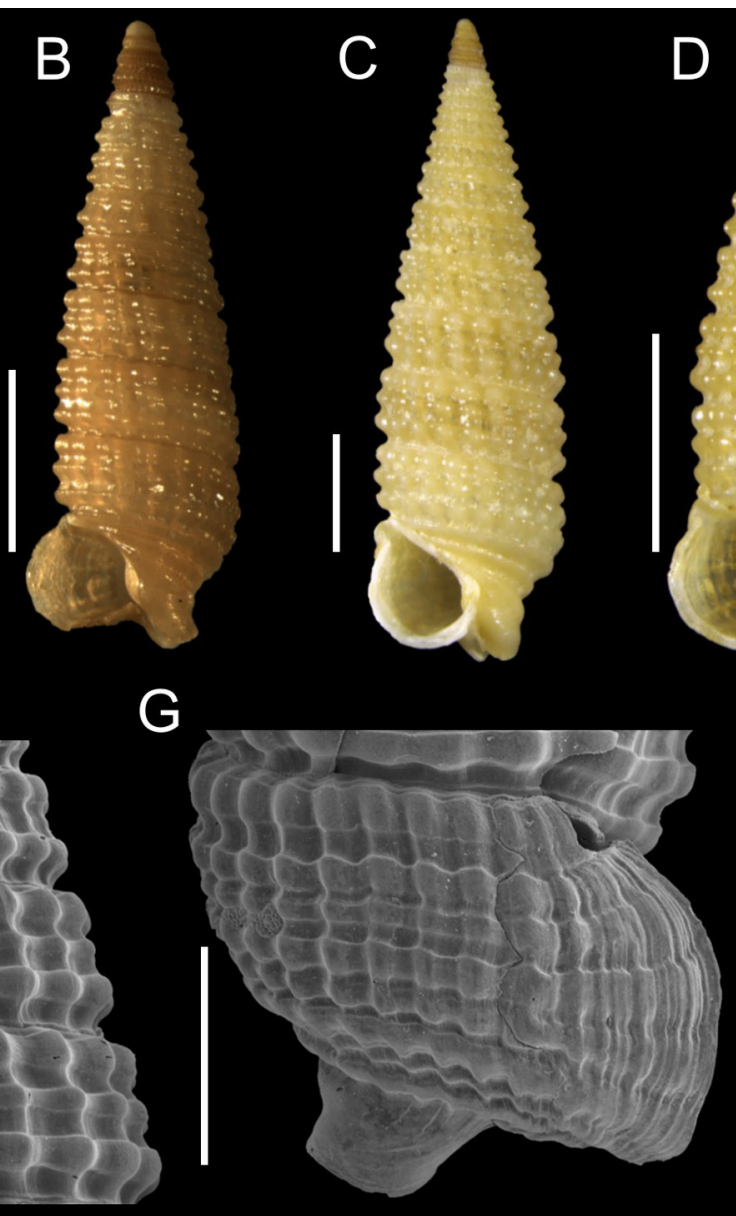

$\mathrm{H}$

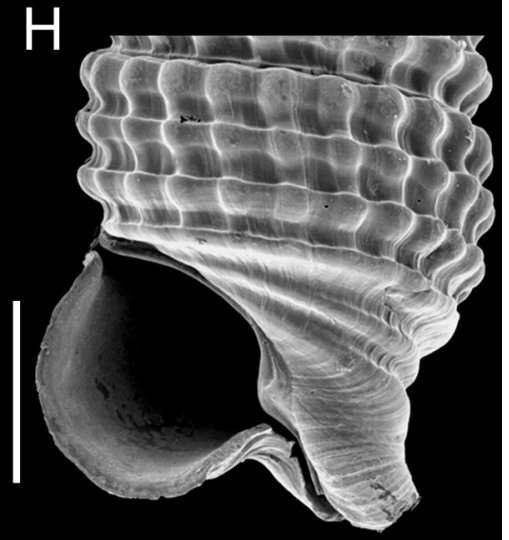

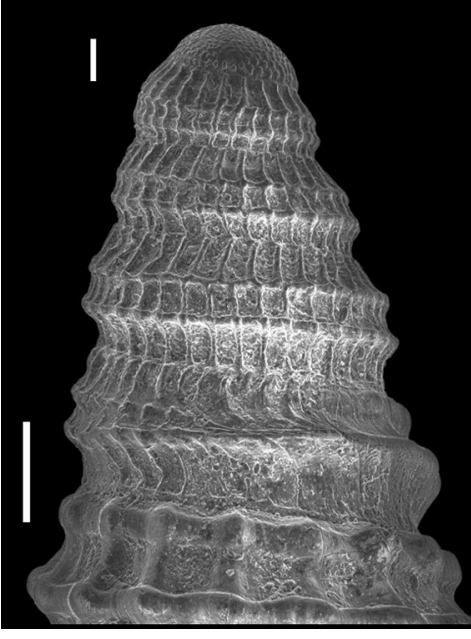

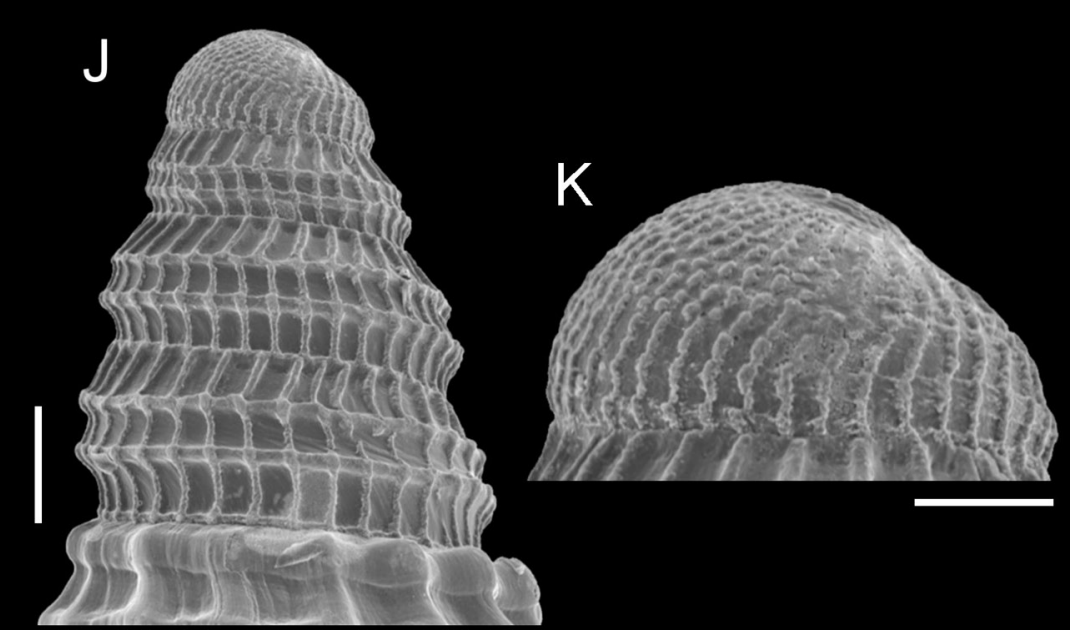

Fig. 93. Sagenotriphora osclausum (Rolán \& Fernández-Garcés, 1995). A. Holotype, MNCN 15.05/17224. B. MNRJ 17956*, $3.46 \mathrm{~mm}$. C. MNRJ 18964*, $5.48 \mathrm{~mm}$. D. MNRJ 18946*, $2.91 \mathrm{~mm}$. E. MNRJ 18381*, $3.35 \mathrm{~mm}$. F-G. MNRJ 17970*. H, J-K. Same shell as E. I. Same shell as C. Scale bars: A-E $=1 \mathrm{~mm} ; \mathrm{F}-\mathrm{H}=500 \mu \mathrm{m} ; \mathrm{I}-\mathrm{J}=100 \mu \mathrm{m} ; \mathrm{K}=50 \mu \mathrm{m}$. Photo credits A: Rafael Araujo $(\mathrm{MNCN})$. 
- 15 specs; BPot 1-MR41; MNRJ 31576* • 15 specs; BPot 1-MR42; MNRJ 31577* • 17 specs; BPot 1-MR43; MNRJ 31578* • 6 specs; BPot 1-MR44; MNRJ 31579* 3 specs; BPot 1-MR45; MNRJ $31580 *$ - 1 spec.; BPot 2-MR32; MNRJ 31581* • 1 spec.; BPot 2-MR41; MNRJ 31582* • 10 specs; BPot 2-MR42; MNRJ 31583* • 5 specs; BPot 2-MR44; MNRJ 31584* 4 specs; BPot 2-MR45; MNRJ 31585* - 1 spec.; 0448'26" S, 36¹0'52" W; depth 178-193 m; 23 May 2011; MNRJ 35112*. - Pernambuco - 1 spec.; Ipojuca, Porto de Galinhas; 28 Mar. 1983; UFRPE. - Alagoas - 2 specs; Maceió, Ponta Verde; FLMNH 507928 • 1 spec.; Maceió, Ponta Verde; MORG 52628 • 1 spec.; Petro/MAR st. 19; UFS. - Sergipe - 6 specs; Petro/UFS st. E5-A1; UFS • 1 spec.; Petro/UFS st. E6-A1; with soft part preservation; UFS • 2 specs; Petro/UFS st. 15.3; with soft part preservation; UFS. - Bahia 1 spec.; Salvador; Apr. 1981; J.C. Tarasconi leg.; CHL • 1 spec.; Salvador; MZSP 133334 • 2 specs; Baía de

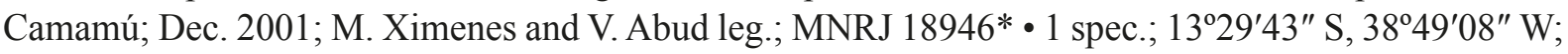

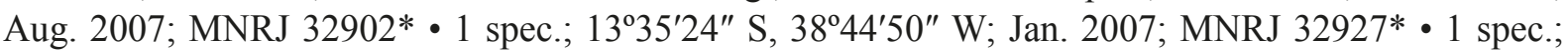

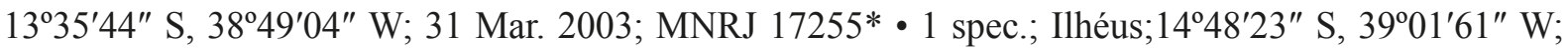
Sep. 2008; T. Ourives leg.; MZSP 91657 • 2 specs; Ilhéus; MNRJ 32373* • 2 specs; Santa Cruz Cabrália; depth 3 m; 19 Jan. 2000; MZSP 57222 • 1 spec.; REVIZEE-Central C5-16R; IBUFRJ 14342 - 6 specs; JOPS st. 3236; MNRJ 33807*. - Espírito Santo - 4 specs; REVIZEE-Central C1-C65; IBUFRJ 9493 - 2 specs; REVIZEE-Central C1-C65; IBUFRJ 12879 1 spec.; REVIZEE-Central C1C65; IBUFRJ 19464 • 2 specs; REVIZEE-Central C1-C65; IBUFRJ $19495 \bullet 8$ specs; REVIZEE-Central C1-C65; MORG 52601 • 4 specs; REVIZEE-Central C1-VV38; IBUFRJ 19609 • 1 spec.; 19²5' S, $39^{\circ} 22^{\prime} \mathrm{W}$; depth $55 \mathrm{~m}$; Oct. 2003; MNRJ 30716* - 1 spec.; 192 $25^{\prime} 05^{\prime \prime} \mathrm{S}, 39^{\circ} 15^{\prime} 54^{\prime \prime} \mathrm{W}$; depth $65 \mathrm{~m}$; Oct. 2003; MNRJ 30704* • 2 specs; 19²5'34" S, 39²2'16" W; depth 42 m; Oct. 2003; MNRJ 32835*

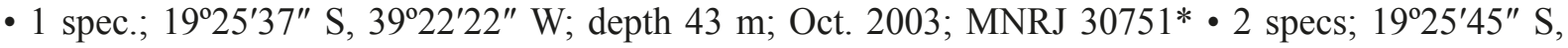
$39^{\circ} 24^{\prime} 58^{\prime \prime}$ W; depth 50 m; Oct. 2003; MNRJ 30758* • 1 spec.; 192 $26^{\prime} 03^{\prime \prime} \mathrm{S}, 39^{\circ} 22^{\prime} 35^{\prime \prime}$ W; depth $44 \mathrm{~m}$; Oct. 2003; MNRJ 32836* 4 specs; REVIZEE-Central C1-VV24; IBUFRJ 19473 • 2 specs; Porto de Ubú; 2047' S, 40³2' W; MNRJ 30899* • 1 spec.; Porto de Ubú; 2047' S, 40³2' W; MNRJ 30900* •

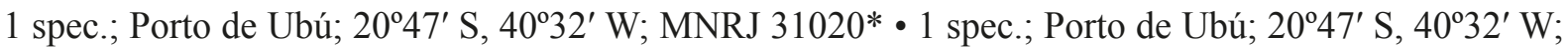
MNRJ 31076* • 1 spec.; Porto de Ubú; 2047' S, 40³2' W; MNRJ 31132* • 2 specs; Porto de Ubú; $20^{\circ} 47^{\prime}$ S, 40³2' W; MNRJ 32420*. - Champlain Seamount - 1 spec.; REVIZEE-Central C5-28R; IBUFRJ 14669. - Campos Basin (Espírito Santo/Rio de Janeiro) - 5 specs; $21^{\circ} 15^{\prime} \mathrm{S}, 40^{\circ} 20^{\prime} \mathrm{W} ; 28$ Aug. 1979; OC. Ship Almirante Câmara leg.; IBUFRJ 7559 • 1 spec.; $20^{\circ} 38^{\prime}$ S, 4008' W; 26 Aug. 1979; OC. Ship Almirante Câmara leg.; IBUFRJ 19507 • 1 spec.; Campos Basin; 26 Aug. 1979; OC. Ship Almirante Câmara leg.; IBUFRJ 19510 • 3 specs; 2053' S, 40¹2' W; 26 Aug. 1979; OC. Ship Almirante Câmara leg.; IBUFRJ 19515 • 2 specs; REVIZEE-Central C1-D1-2; IBUFRJ 19531 • 4 specs; REVIZEE-Central C1-VV21; MNRJ 33795* 4 specs; REVIZEE-Central C1-VV21 IBUFRJ $19540 \bullet$ 2 specs; REVIZEE-Central C1-D3; IBUFRJ 19555 • 4 specs; REVIZEE-Central C1-D3; IBUFRJ 19591 - 3 specs; HAB 13-H2; MNRJ 17952* - 3 specs; HAB 13-H2; MNRJ 17956* - 3 specs; HAB 13H2; MNRJ 17970* • 2 specs; HAB 13-H2; MNRJ 17954* 1 spec.; HAB 13-H2; MNRJ 17971* • 2 specs; HAB 11-G4; MNRJ 17966* 1 spec.; HAB 13-H4; MNRJ 17980* • 5 specs; HAB 16-G3; MNRJ 18378* • 2 specs; HAB 16-B4; MNRJ 18381* • 1 spec.; HAB 16-C3; MNRJ 18384* 2 specs; HAB 16-H2; MNRJ 18385* • 1 spec.; HAB 17-I4; MNRJ 18386*• 1 spec.; HAB 17-I1; MNRJ 18387* - 2 specs; HAB 16-H3; MNRJ 18388* • 1 spec.; HAB 16-G4; MNRJ 18401* • 1 spec.; HAB 16-C4; MNRJ 18430* 2 specs; HAB 13-H2; MNRJ 18590* 2 specs; $23^{\circ} 04^{\prime}$ S, $40^{\circ} 59^{\prime}$ W; 17 Dec. 2004; MNRJ 18964* • 1 spec.; HAB 13-H3; MNRJ 30827* • 1 spec.; $22^{\circ} 42^{\prime} \mathrm{S}, 40^{\circ} 40^{\prime} \mathrm{W}$; depth 5-10 m; 14 Apr. 2005; MNRJ 32406* • 1 spec.; REVIZEE-Central C1-VV21; MORG 52203. - Rio de Janeiro • 4 specs; Búzios, Praia da Ferradura; MNRJ 18604* • 1 spec.; Ilha Grande, Ponta da Enseada; RAP-BIG st. 31; UERJ 5181 • 4 specs; Ilha Grande, Praia do Furtado; 22 Jul. 1966; MZSP 51995. - São Paulo • 1 spec.; Ubatuba; D. Fiore leg.; MZSP 24656 • 1 spec.; Ubatuba, Enseada do Flamengo; 7 Jan. 1956; W. Narchi leg.; MNHN-Mo 7640*• 1 spec.; Ubatuba; depth 9 m; 23 Mar. 1961; MZSP 52025 • 1 spec.; REVIZEE-Sul st. 6686; MZSP 133504. 
CUBA・ 1 spec.; Varadero, Matanzas; H. Monroe leg.; FLMNH 151638.

MEXICO • 1 spec.; Yucatan; depth 84-89 m; BMSM 107193.

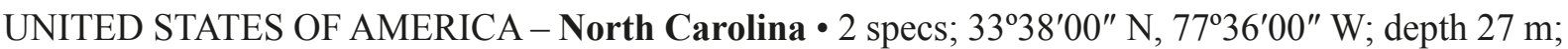

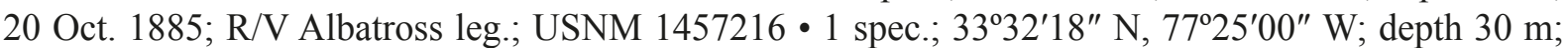
21 Oct. 1981; with soft part preservation; USNM 850623. - Florida 4 specs; Palm Beach County, off Lantana; 3 Aug. 1939; W. Lyman leg.; FLMNH 10241 • 1 spec.; Palm Beach County, off Boynton Inlet; H. Akers leg.; FLMNH 507934 • 1 spec.; Palm Beach County, Delray Beach; 1 Apr. 1979; J. Lightfoot leg.; FLMNH 507936.

\section{Similiphora intermedia (C.B. Adams, 1850)}

Fig. 94

Cerithium intermedium C.B. Adams, 1850: 119.

Triforis intermedius - Dautzenberg 1900: 195.

Triforis intermedia - Dall \& Simpson 1901: 423.

Triphora pulchella auct. non C.B. Adams, 1850 - Lange-de-Morretes 1949: 80. - Parker \& Curray 1956: 2434. — Porta \& Porta 1960: 42. — Houbrick 1968: 14. — Rios 1970: 46; 1975: 51, pl. 13 fig. 190; 1985: 161, pl. 53 fig. 764; 1994: 95, pl. 31 fig. 377; 2009: 173. — Abbott 1974: 112, fig. 1135. — Vokes \& Vokes 1983: 18, pl. 27 fig. 17. — Robinson \& Montoya 1987: 384. — Absalão 1989: 3. - Absalão et al. 2006: 238. — Santos et al. 2007: 226. —Agudo-Padrón 2015: 65.

Cerithium intermedium - Clench \& Turner 1950: 293, pl. 38 fig. 9.

Triphora intermedia - Parker \& Curray 1956: 2434. - Warmke \& Abbott 1962: 77. — Cooley 1978: 60. — Robinson \& Montoya 1987: 384. — De Jong \& Coomans 1988: 50. — Díaz 1994: 33. — Hess \& Abbott 1994: 147.

Triphora sp. "C" - Rice \& Kornicker 1962: 120, pl. 2 fig. 16.

Triphora (Cosmotriphora) pulchella - Odé 1989: 111, non C.B. Adams, 1850.

Similiphora intermedia - Rolán \& Fernández-Garcés 1995: 12, figs 17-19; 2007: 24, pl. 5 figs 6-12; 2015: 54, pl. 4 figs $m-n$, not fig. k. — Redfern 2001: 68, pl. 33 fig. 286; 2013: 130, fig. 372. Espinosa \& Ortea 2001: 20. - Sevilla et al. 2003: 342. - Espinosa et al. 2007: 74, fig. 55; 2012: 257. — Lee 2009: 91. — Garcia \& Lee 2011. — Zhang 2011: 101, fig. 303. — Lamy \& Pointier 2018: 289, pl. 92 fig. 8. — Fernandes \& Pimenta 2019a: 39, figs 2j, 25-27.

\section{Material examined}

BRAZIL - North Brazil • 2 specs; REVIZEE-Norte III st. 176; UFMA* • 1 spec.; REVIZEE-Norte III st. 211A; UFMA*. - Pará • 1 spec.; 00 ${ }^{\circ} 10^{\prime}$ S, 46 $46^{\circ} 00^{\prime} \mathrm{W}$; depth 35 m; Jan. 1981; MORG 52607. - Rio Grande do Norte 1 spec.; BPot 1-MR11; MNRJ 31460* • 1 spec.; BPot 1-MR22; MNRJ 31461* • 1 spec.; BPot 1-MR23; MNRJ 31462* • 2 specs; BPot 1-MR25; MNRJ 31463* • 2 specs; BPot 1-MR31; MNRJ 31464* • 4 specs; BPot 1-MR32; MNRJ 31465* • 1 spec.; BPot 1-MR34; MNRJ 31466* • 9 specs; BPot 1-MR41; MNRJ 31467* • 5 specs; BPot 1-MR42; MNRJ 31468* • 3 specs; BPot 1-MR43; MNRJ 31469* • 1 spec.; BPot 1-MR45; MNRJ 31470* • 2 specs; BPot 2-MR22; MNRJ 31471* • 1 spec.; BPot 2-MR23; MNRJ 31472* • 4 specs; BPot 2-MR32; MNRJ 31473* • 1 spec.; BPot 2-MR33; MNRJ 31479* • 1 spec.; BPot 2-MR34; MNRJ 31474* • 2 specs; BPot 2-MR41; MNRJ 31475* • 3 specs; BPot 2-MR42; MNRJ 31476* • 4 specs; BPot 2-MR 44; MNRJ 31477* • 4 specs; BPot 2-MR45; MNRJ 31478* • 1 spec.; Genipabu; 1966; Cabral-Nasser leg.; MORG 12867. - Alagoas • 1 spec.; Maceió, Ponta Verde; 1992; IBUFRJ 4351 • 2 specs; Maceió, Jaraguá; MNRJ 18612* • 20 specs; Maceió, Jaraguá; MORG 33738 • 2 specs; Petro/MAR st. 21; UFS. - Sergipe • 1 spec.; Petro/UFS st. E5-A2; with soft part preservation; UFS • 1 spec.; Petro/UFS st. E6-A2; UFS. - Bahia • 3 specs; Salvador, 
Itapuã; Apr. 1982; G. Oliveira leg.; MORG 22195 • 1 spec.; Salvador, Itapuã; Feb. 1990; P.M.S. Costa leg.; MORG 27669 • 5 specs; Salvador, Itapuã; MORG 33731 • 3 specs; Salvador, Itapuã; MORG 52616 • 1 spec.; Salvador, Itapuã; MZSP 63878 • 1 spec.; Salvador, Itapuã; MZSP $133313 ・ 1$ spec.; Salvador, Itapuã; MZSP 133318 • 1 spec.; 13²9'22" S, 38²48'43" W; Jun. 2007; MNRJ 32914*・1 spec.; Cairu,

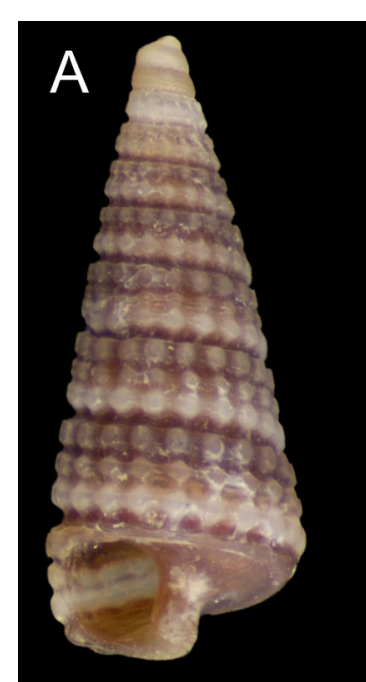

F

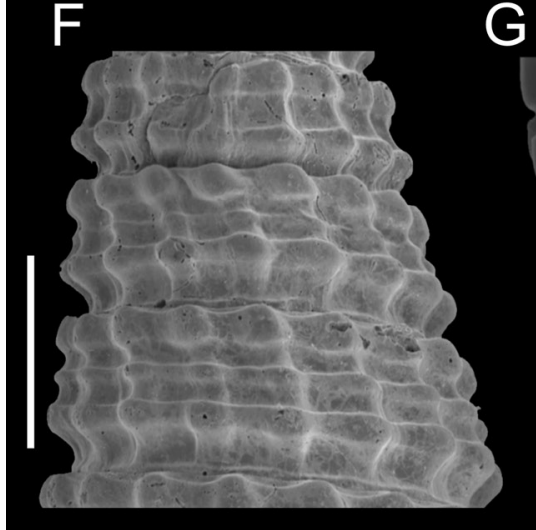

$\mathbf{G}$

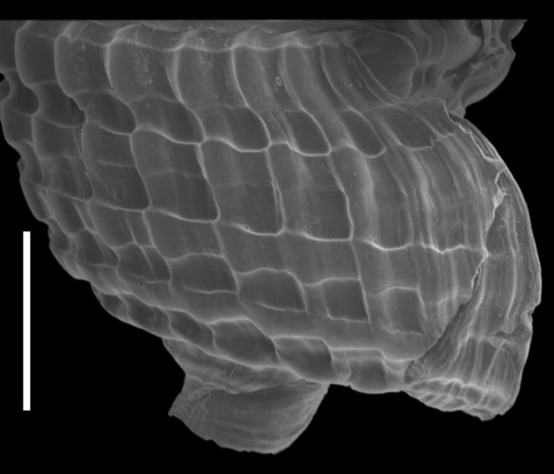

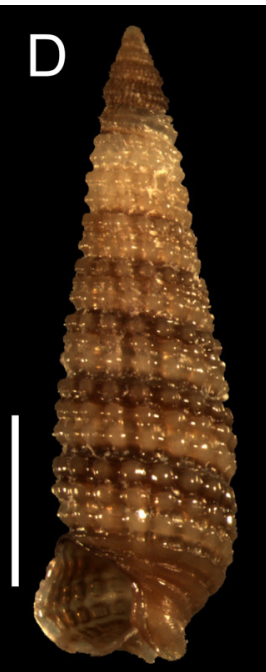

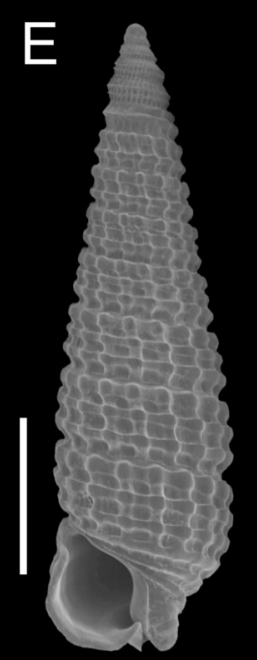

$\mathrm{H}$

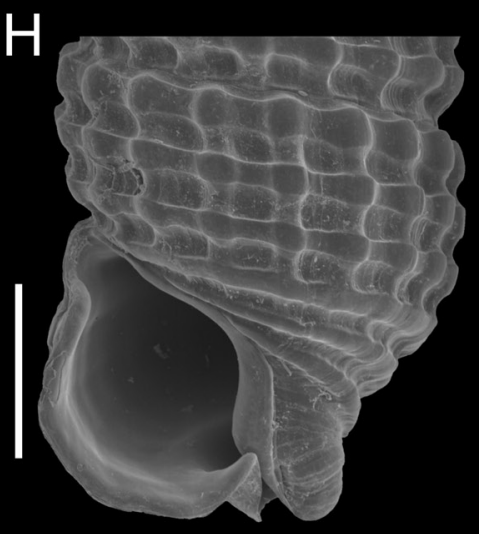

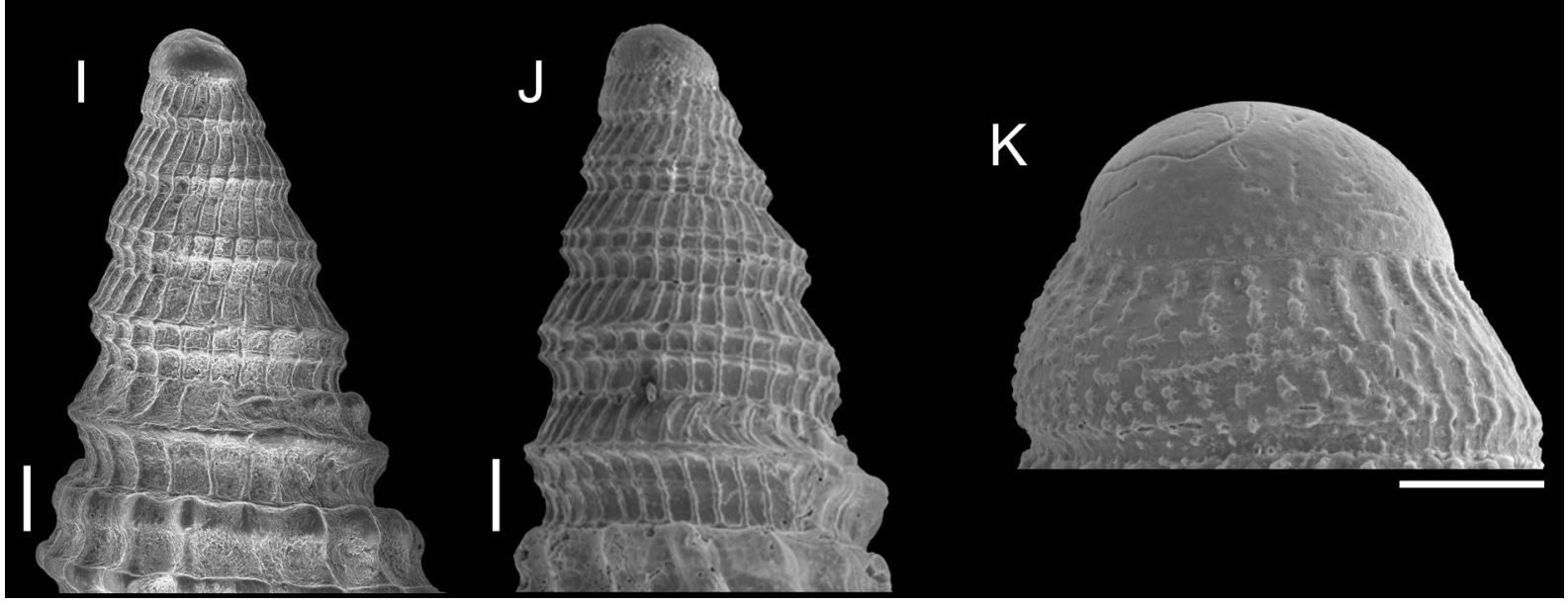

Fig. 94. Similiphora intermedia (C.B. Adams, 1850). A. Lectotype, MCZ 186161. B. MNRJ 17967*, $5.42 \mathrm{~mm}$. C. MNRJ 29763*, $5.12 \mathrm{~mm}$. D. MNRJ 18953*, $3.73 \mathrm{~mm}$. E, H. Same shell as D. F, J. MNRJ 17976*. G, K. Same shell as C. I. MNRJ 34027*. Scale bars: A-E $=1 \mathrm{~mm} ; \mathrm{F}-\mathrm{H}=500 \mu \mathrm{m}$; $\mathrm{I}-\mathrm{J}=100 \mu \mathrm{m} ; \mathrm{K}=50 \mu \mathrm{m}$. 
Morro de São Paulo, Praia de Garapuá; depth 5 m; 2011; P. Coelho-Filho leg.; with soft part preservation; MZSP 100746 • 1 spec.; off Boipeba; depth 35-55 m; Dec. 2002; M. Ximenez leg.; MORG 43762 • 7 specs; Ilhéus; MNRJ 32371* • 3 specs; Ilhéus; MNRJ 32974* • 1 spec.; off Canavieiras; Apr. 2011; MNRJ 30711* • 1 spec.; off Canavieiras; Apr. 2011; MNRJ 30721* • 1 spec.; off Canavieiras; Apr. 2011; MNRJ 30755* • 3 specs; off Canavieiras; Apr. 2011; MNRJ 33121* • 1 spec.; Abrolhos; Feb. 1978; MORG 52609 • 1 spec.; Abrolhos; Feb. 1978; MORG 20266 • 9 specs; Abrolhos; Jan. 1985; MORG 23827 - 1 spec.; Abrolhos; Jan. 1985; MORG 52606. - Espírito Santo • 9 specs; REVIZEE-Central C1-VV31; IBUFRJ 19483 • 1 spec.; REVIZEE-Central C1-VV33; MORG 39115 • 3 specs; REVIZEE-Central C1C65; IBUFRJ 19460 • 1 spec.; REVIZEE-Central C1-C65; IBUFRJ $19498 \bullet 1 \mathrm{spec}$.; REVIZEE-Central C1-C65; MORG 40895 - 7 specs; REVIZEE-Central C1-C65; MORG 52599 • 2 specs; REVIZEECentral C1-C64; IBUFRJ 19494 • 1 spec.; REVIZEE-Central C1-VV38; IBUFRJ 19524 • 5 specs; REVIZEE-Central C1-VV38; IBUFRJ 19606 - 3 specs; 19²2'46" S, 39³9'26" W; depth 12 m; Oct. 2003; MNRJ 31166* • 1 spec.; 19²4'23" S, 39 34'42" W; depth 24 m; Oct. 2003; MNRJ 31162* • 6 specs; $19^{\circ} 24^{\prime} 52^{\prime \prime} \mathrm{S}, 39^{\circ} 22^{\prime} 00^{\prime \prime} \mathrm{W}$; depth 42 m; Oct. 2003; MNRJ 30753* 4 specs; $19^{\circ} 25^{\prime} \mathrm{S}, 39^{\circ} 22^{\prime} \mathrm{W}$;

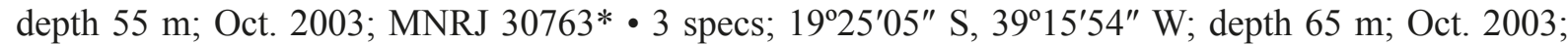
MNRJ 30701* • 6 specs; $19^{\circ} 25^{\prime} 08^{\prime \prime}$ S, 39 $9^{\circ} 15^{\prime} 59^{\prime \prime}$ W; depth 65 m; Oct. 2003; MNRJ 30768* • 3 specs; $19^{\circ} 25^{\prime} 34^{\prime \prime}$ S, 39²2'16" W; depth 42 m; Oct. 2003; MNRJ 30717* • 4 specs; 19²5'34" S, 39 $22^{\prime} 16^{\prime \prime}$ W; depth 42 m; Oct. 2003; MNRJ 31163* • 9 specs; 19²5'37" S, 39 $22^{\prime 2} 22^{\prime \prime}$ W; depth 43 m; Oct. 2003; MNRJ 30748* • 4 specs; 19²5'37" S, 39²2'22" W; depth 43 m; Oct. 2003; MNRJ 30764* • 1 spec.; $19^{\circ} 25^{\prime} 37^{\prime \prime}$ S, 39²2'22" W; depth 43 m; Oct. 2003; MNRJ 30891* • 2 specs; 19²5'45" S, 39²4'58" W;

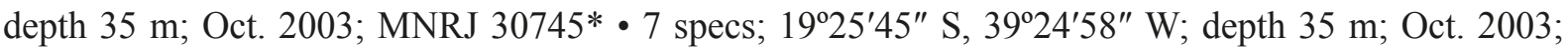
MNRJ 30759* • 1 spec.; 1925'45" S, 39 24'58" W; depth 35 m; Oct. 2003; MNRJ 32126* • 10 specs; $19^{\circ} 25^{\prime} 54^{\prime \prime}$ S, 39²4'58" W; depth 50 m; Oct. 2003; MNRJ 30747* • 1 spec.; $19^{\circ} 26^{\prime}$ S, 39²2' W; depth 46-55 m; Oct. 2003; MNRJ 30705* - 2 specs; $19^{\circ} 26^{\prime} \mathrm{S}, 39^{\circ} 22^{\prime} \mathrm{W}$; depth 46-55 m; Oct. 2003; MNRJ 30724* - 7 specs; $19^{\circ} 26^{\prime} \mathrm{S}$, 39 $22^{\prime} \mathrm{W}$; depth 46-55 m; Oct. 2003; MNRJ 30930* 1 spec.; $19^{\circ} 26^{\prime} \mathrm{S}, 39^{\circ} 22^{\prime} \mathrm{W}$; depth 46-55 m; Oct. 2003; MNRJ 32150* 2 specs; $19^{\circ} 26^{\prime} \mathrm{S}, 39^{\circ} 22^{\prime} \mathrm{W}$; depth 46-55 m; Oct. 2003; MNRJ $32163^{*} \cdot 3$ specs; $19^{\circ} 26^{\prime} \mathrm{S}, 39^{\circ} 22^{\prime} \mathrm{W}$; depth 46-55 m; Oct. 2003MNRJ $32165^{*}$ - 3 specs; $19^{\circ} 26^{\prime} 03^{\prime \prime} \mathrm{S}, 39^{\circ} 22^{\prime} 35^{\prime \prime} \mathrm{W}$; depth 44 m; Oct. 2003; MNRJ 32431* • 1 spec.; 19 $26^{\prime} 03^{\prime \prime} \mathrm{S}$, $39^{\circ} 22^{\prime} 35^{\prime \prime} \mathrm{W}$; depth $44 \mathrm{~m}$; Oct. 2003; MNRJ 32467* • 4 specs; $19^{\circ} 26^{\prime} 19^{\prime \prime} \mathrm{S}, 39^{\circ} 15^{\prime} 17^{\prime \prime} \mathrm{W}$; depth $53 \mathrm{~m}$;

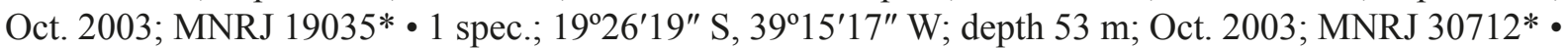

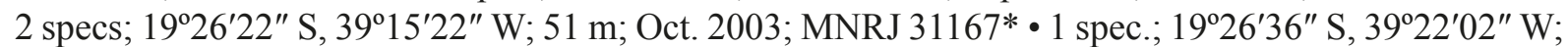
depth 50 m; Oct. 2003; MNRJ 30765* • 4 specs; REVIZEE-Central C6-R2\#1-1; IBUFRJ 16257 • 6 specs; REVIZEE-Central C1-VV24; IBUFRJ 19471 - 6 specs; REVIZEE-Central C1-VV24; MORG $40544 \cdot 5$ specs; 1940'26" S, 39³6'19" W; depth 40 m; 2 Dec. 2011; OC. Ship Seward Johnson; MNRJ 34829*• 1 spec.; $20^{\circ} 10^{\prime} 02^{\prime \prime}$ S, 4008'31" W; depth 25 m; 2 Dec. 2011; OC. Ship Seward Johnson; MNRJ 34981*• 12 specs; $20^{\circ} 14^{\prime} \mathrm{S}, 40^{\circ} 12^{\prime} \mathrm{W}$; Jun. 2008; MNRJ 32647* 7 specs; $20^{\circ} 18^{\prime} \mathrm{S}, 40^{\circ} 14^{\prime} \mathrm{W}$; Mar. 1993; V. Abud leg.; MORG 40025 • 4 specs; Guarapari; 1970; MORG 16296 • 2 specs; Guarapari; Jan. 2013; MNRJ 34027* • 1 spec.; Guarapari, off Meaípe; depth 20-25 m; Sep. 1997; A. Bodart leg.; MZSP 64403 • 2 specs; Porto de Ubú; 2047' S, 40³2' W; Sep. 2007; MNRJ 30836* • 1 spec.; Porto de Ubú; 2047' S, 40³2' W; Sep. 2007; MNRJ 30897* • 1 spec.; Porto de Ubú; 2047' S, 40³2' W; Sep. 2007; MNRJ 30907* • 26 specs; Porto de Ubú; 2047' S, 40³2' W, Nov. 2007; MNRJ 32410* • 5 specs; Porto de Ubú; $20^{\circ} 47^{\prime}$ S, $40^{\circ} 32^{\prime}$ W; Oct. 2008; MNRJ 31011* • 1 spec.; Porto de Ubú; $20^{\circ} 47^{\prime}$ S, $40^{\circ} 32^{\prime}$ W; Oct. 2008; MNRJ 31013* • 1 spec.; Porto de Ubú; $20^{\circ} 47^{\prime}$ S, $40^{\circ} 32^{\prime}$ W; Oct. 2008; MNRJ 31014* • 2 specs; Porto de Ubú; 2047' S, 40³2' W; Oct. 2008; MNRJ 31021* • 3 specs; Porto de Ubú; $20^{\circ} 47^{\prime}$ S, $40^{\circ} 32^{\prime}$ W; Oct. 2008; MNRJ 31022* • 2 specs; Porto de Ubú; $20^{\circ} 47^{\prime}$ S, $40^{\circ} 32^{\prime}$ W; Oct. 2008; MNRJ $31026^{*}$ - 1 spec.; Porto de Ubú; 2047' S, 40³2' W; Nov. 2009; MNRJ 31006* • 4 specs; Porto de Ubú; $20^{\circ} 47^{\prime}$ S, 40³2' W; Nov. 2009; MNRJ 31008* - 2 specs; Porto de Ubú; 2047' S, 40³2' W; Mar. 2010; MNRJ 31035* • 3 specs; Porto de Ubú; 2047' S, 40²' W; Mar. 2010; MNRJ 31037* • 3 specs; Porto de Ubú; 2047' S, 40³2' W; Mar. 2010; MNRJ 31049* - 2 specs; Porto de Ubú; 2047' S, 40³2' W; Mar. 2010; MNRJ 31055* • 2 specs; Porto de Ubú; 2047' S, 40³2’ W; Mar. 2010; MNRJ 31059* 4 specs; 
Porto de Ubú; 2047' S, 40³2' W; Mar. 2010; MNRJ 31066* • 3 specs; Porto de Ubú; $20^{\circ} 47^{\prime}$ S, 40³2' W; Mar. 2010; MNRJ 31067* • 3 specs; Porto de Ubú; 2047' S, 40³2' W; Mar. 2010; MNRJ 31072* • 1 spec.; Porto de Ubú; 204' S, 40³2' W; Mar. 2010; MNRJ 31074*• 1 spec.; Porto de Ubú; $20^{\circ} 47^{\prime}$ S,

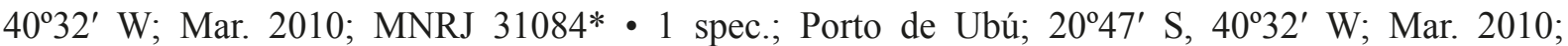
MNRJ 31090* • 2 specs; Porto de Ubú; 2047' S, 40³2' W; Mar. 2010; MNRJ 31095* • 1 spec.; Porto de Ubú; 2047' S, 40³2' W; Mar. 2010; MNRJ 31098* • 5 specs; Piúma; 1993; IBUFRJ 5595 • 29 specs; Piúma; 1993; IBUFRJ 8624 • 1 spec.; Piúma; 1998; L.R.L. Simone leg.; MZSP 84798. - Campos Basin (Espírito Santo/Rio de Janeiro) • 2 specs; $21^{\circ} 09^{\prime}$ S, 40³1' W; 27 Aug. 1979; OC. Ship Almirante Câmara leg.; IBUFRJ 7557 • 4 specs; 2047' S, 40²6' W; 29 Aug. 1979; OC. Ship Almirante Câmara leg.; IBUFRJ $7560 \bullet 9$ specs; $20^{\circ} 53^{\prime}$ S, $40^{\circ} 12^{\prime} \mathrm{W}$; 26 Aug. 1979; OC. Ship Almirante Câmara leg.; IBUFRJ 7561 - 3 specs; $20^{\circ} 42^{\prime}$ S, 4006' W; 27 Aug. 1979; OC. Ship Almirante Câmara leg.; IBUFRJ 7565 • 5 specs;

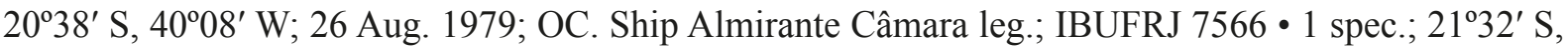
40²5' W; 28 Aug. 1979; OC. Ship Almirante Câmara leg.; IBUFRJ $7634 \cdot 1$ spec.; $21^{\circ} 40^{\prime}$ S, 40 $02^{\circ}$ W; 28 Aug. 1979; OC. Ship Almirante Câmara leg.; IBUFRJ 7684 • 4 specs; REVIZEE-Central C1-VV17; IBUFRJ 9643 • 1 spec.; REVIZEE-Central C1-VV22; IBUFRJ 11368 • 1 spec.; REVIZEE-Central C235R; IBUFRJ 12895 • 3], IBUFRJ 12896; 9], IBUFRJ 19489: REVIZEE-Central C1-VV16 • 3 specs;

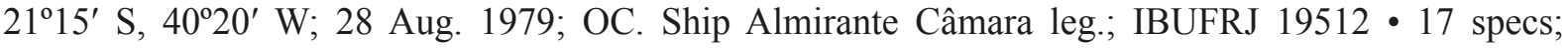
REVIZEE-Central C1-D1-2; IBUFRJ 19528 • 4 specs; REVIZEE-Central C1-VV21; IBUFRJ $19541 \bullet$ 3 specs; REVIZEE-Central C1-D3; IBUFRJ 19554 • 15 specs; REVIZEE-Central C1-D3; IBUFRJ 19588 - 1 spec.; REVIZEE-Central C1-VV22; IBUFRJ 19570 • 1 spec.; HAB 13-I4; MNRJ 17944* • 1 spec.; HAB 13-H4; MNRJ 17948* • 2 specs; HAB 11-G3; MNRJ 17949*• 1 spec.; HAB 11-G4; MNRJ 17950* - 4 specs; HAB 13-I2; MNRJ 17955* 15 specs; HAB 13-H2; MNRJ 17967* • 2 specs; HAB 13-H3; MNRJ 17969*• 1 spec.; HAB 11-D3; MNRJ 17972* • 2 specs; HAB 11-C3; MNRJ 17974* • 4 specs; HAB 11-B5; MNRJ 17976* • 1 spec.; HAB 11-B4; MNRJ 17977*• 9 specs; HAB 13-H1; MNRJ 17982* - 2 specs; HAB 16-C4; MNRJ 18376* • 6 specs; HAB 16-C3; MNRJ 18380* • 1 spec.; HAB 16-G4; MNRJ 18396* 15 specs; HAB 17-I2; MNRJ 18411* • 2 specs; HAB 16-H4; MNRJ 18413* • 3 specs; HAB 16-H3; MNRJ 18416* • 4 specs; HAB 16-G3; MNRJ 18418* • 8 specs; HAB 16-H2; MNRJ $18433^{*}$ - 1 spec.; $22^{\circ} 42^{\prime}$ S, $40^{\circ} 40^{\prime} \mathrm{W}$; depth 5-10 m; 14 Apr. 2005; MNRJ $32405^{*} \bullet 4$ specs; $22^{\circ} 42^{\prime}$ S, $40^{\circ} 40^{\prime} \mathrm{W}$;

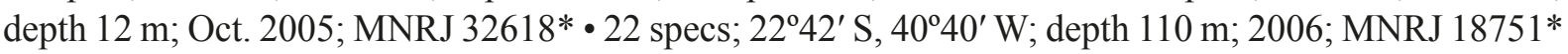
- 3 specs; $22^{\circ} 42^{\prime} \mathrm{S}, 40^{\circ} 40^{\prime} \mathrm{W}$; depth 5-10 m; Mar. 2007; MNRJ 15402* -4 specs; $22^{\circ} 42^{\prime} \mathrm{S}, 40^{\circ} 40^{\prime} \mathrm{W}$; depth 5-10 m; MNRJ 18953* • 3 specs; 2304' S, 4059' W; 17 Dec. 2004; MNRJ 18969* • 65 specs;

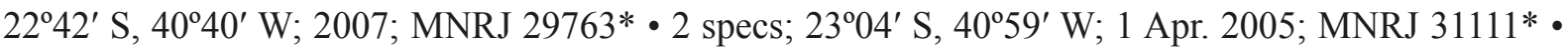
1 spec.; $23^{\circ} 03^{\prime} 18^{\prime \prime}$ S, $41^{\circ} 02^{\prime} 06^{\prime \prime}$ W; Oct. 2008; MNRJ 32063* • 2 specs; $23^{\circ} 15^{\prime} 00^{\prime \prime}$ S, $41^{\circ} 06^{\prime} 00^{\prime \prime}$ W; Oct. 2008; MNRJ 32064* • 1 spec.; 2304' S, 4059' W; Jul. 2005; MNRJ 32353* • 3 specs; REVIZEECentral C1-VV22; MORG 40425 • 1 spec.; REVIZEE-Central C1-VV22; MORG 52260 • 1 spec.; REVIZEE-Central C1-VV21; MORG 52201. - Almirante Saldanha Seamount • 3 specs; REVIZEECentral C1-D1; MNRJ 33760. - Rio de Janeiro - 11 specs; $21^{\circ} 49^{\prime} 04^{\prime \prime}$ S, 41 ${ }^{\circ} 00^{\prime} 04^{\prime \prime}$ W, São João da Barra, Porto do Açu; Jul. 2012; MZSP 111122 • 4 specs; $21^{\circ} 49^{\prime} 04^{\prime \prime}$ S, 41 ${ }^{\circ} 00^{\prime} 04^{\prime \prime}$ W, São João da Barra, Porto do Açu; Jul. 2012; MZSP 111181 • 7 specs; Búzios, Praia da Ferradura; MNRJ 18602* • 1 spec.; Cabo Frio; 17 Feb. 1970; J. Colella leg.; MZSP 57208 • 1 spec.; Arraial do Cabo; depth 25-30 m; Aug. 2003; P. Gonçalves leg.; MZSP 39606 • 1 spec.; Ilha do Calombo, Angra dos Reis; RAP-BIG st. 26; UERJ 5394 • 1 spec.; Ilha de Búzios, Angra dos Reis; RAP-BIG st. 23; UERJ 5452 • 1 spec.; Ilha de Búzios, Angra dos Reis; RAP-BIG st. 23; UERJ 7567 • 1 spec.; RAP-BIG st. 22; UERJ 7557 • 1 spec.; Ilha Grande, Enseada de Lopes Mendes; RAP-BIG st. 34; UERJ 5297 • 1 spec.; Ilha Grande, Enseada de Lopes Mendes; RAP-BIG st. 34; UERJ 7547. - São Paulo • 1 spec.; Ubatuba; MZSP 78290 - 1 spec.;

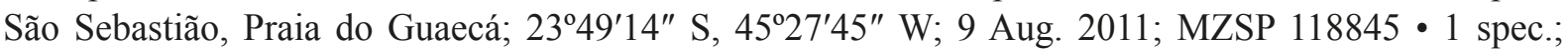
PADCT st. 6571; MZSP 133490 • 2 specs; PADCT st. 6577; MZSP 133494 • 5 specs; REVIZEE-Sul st. 6657; MNRJ 60193. - Santa Catarina - 2 specs; Bombinhas, Praia da Sepultura; 27 08'24" S, 482'ㄴ' $4^{\prime \prime}$ W; depth 0-5 m; 17 Dec. 2019; M.R. Fernandes and A.D. Pimenta leg.; MNRJ 23366. 
COLOMBIA • 1 spec.; Cartagena, Isla Baru, Playa Blanca; 10¹0'38" N, 75³9'06" W; 21 Mar. 2011; MNRJ 18629*.

UNITED STATES OF AMERICA - North Carolina • 6 specs; $34^{\circ} 11^{\prime} 00^{\prime \prime} \mathrm{N}, 76^{\circ} 10^{\prime} 30^{\prime \prime} \mathrm{W}$; depth $95 \mathrm{~m}$;

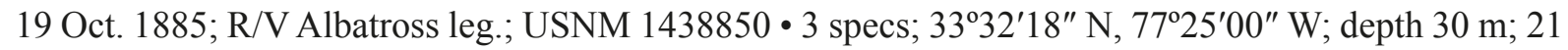
Oct. 1981; with soft part preservation; USNM 850622 - 2 specs; $33^{\circ} 32^{\prime} 18^{\prime \prime} \mathrm{N}, 77^{\circ} 25^{\prime} 00^{\prime \prime} \mathrm{W}$; depth $30 \mathrm{~m}$; 21 Oct. 1981; with soft part preservation; USNM 850624. - South Carolina • 1 spec.; 32 $48^{\prime} 36^{\prime \prime} \mathrm{N}$, 78 39'36" W; depth 34 m; 6 May 1981; Oregon R/V leg.; with soft part preservation; USNM 850958. - Georgia • 2 specs; 31 $41^{\prime} 06^{\prime \prime}$ N, 80²0'48" W; depth 27 m; 14 May 1981; Bagby R/V leg.; with soft part preservation; USNM 850621. - Florida - 3 specs; off Boynton Beach; depth 27-55 m; Sep. 1967; BMSM 67476 • 1 spec.; Brower County, Deerfield Beach; depth 3-4 m; Jul. 1998; P. Souza leg.; MZSP 41482.

\section{Remarks}

The names Cerithium pulchellum C.B. Adams, 1850 or Triphora pulchella were used by many authors (e.g., Abbott 1974; Rios 2009). It is a junior homonym of Cerithium pulchellum Sowerby, 1832, a senior synonym of the cerithiopsid Horologica pupa (Dall \& Simpson, 1901) (De Jong \& Coomans 1988; Rolán \& Espinosa 1992) and its type material is lost (Clench \& Turner 1950). Thus, C. pulchellum C.B. Adams, 1850 is not a synonym of $S$. intermedia, as suggested by Rolán \& Fernández-Garcés (2007, 2008), but T. pulchella auct. non C.B. Adams, 1850 is indeed a synonym.

Another problematic name is Triphoris pulchellus A. Adams, 1854, which Albano et al. (2019: 171) wrongly indicated was regarded as a synonym of Similiphora intermedia by Rolán \& Fernández-Garcés (2008); actually, Rolán \& Fernández-Garcés (2008) referred to the species of C.B. Adams (1850), not A. Adams (1854). Because the single type of Triphoris pulchellus A. Adams, 1854 has a broken apex (without protoconch, preventing a precise identification) and the type locality is unknown, it must be regarded as a nomen dubium (but not regarded as homonym of the cerithiopsid Cerithium pulchellum C.B. Adams, 1850). If this is indeed a Caribbean shell, the most similar species is Triphora atlantica Smith, 1890, although apparently without the spiral microsculpture observed in T. pulchellus A. Adams, 1854 (Albano et al. 2019: fig. 7h).

Strobiligera inaudita (Rolán \& Lee, 2008)

Triphora inaudita Rolán \& Lee in Rolán \& Fernández-Garcés 2008: 150, fig. 26a-d.

Triphora inaudita - Garcia \& Lee 2011.

Strobiligera inaudita - Fernandes \& Pimenta 2014: 167, fig. 2.

\section{Material examined}

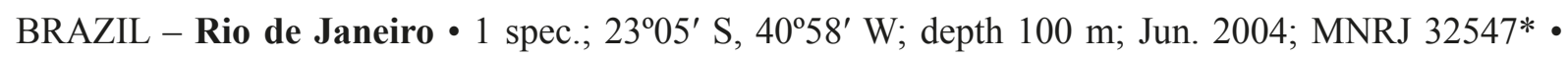
1 spec.; $23^{\circ} 05^{\prime} \mathrm{S}, 40^{\circ} 58^{\prime} \mathrm{W}$; $100 \mathrm{~m}$; Jun. 2004; MNRJ 33078* • 1 spec.; $23^{\circ} 41^{\prime} 06^{\prime \prime} \mathrm{S}, 41^{\circ} 28^{\prime} 12^{\prime \prime} \mathrm{W}$; depth 163 m; Oct. 2008; MNRJ 32042*. - São Paulo • 1 spec.; REVIZEE-Sul st. 6666; MNRJ 29378* - 3 specs; PADCT st. 6573; MNRJ 27844* • 1 spec.; REVIZEE-Sul st. 6676; MZSP 133501 • 6 specs; PADCT st. 6577; MZSP 133492.

\section{Triphora atlantica Smith, 1890}

Fig. 95

Triforis atlantica Smith, 1890: 292, pl. 21 fig. 26. 
Triphora atlantica - Rolán \& Fernández-Garcés 2008: 146, fig. 25a-i. — Lee 2009: 92. — Garcia \& Lee 2011. - Fernandes et al. 2013: 15, figs 15, 26, 36.
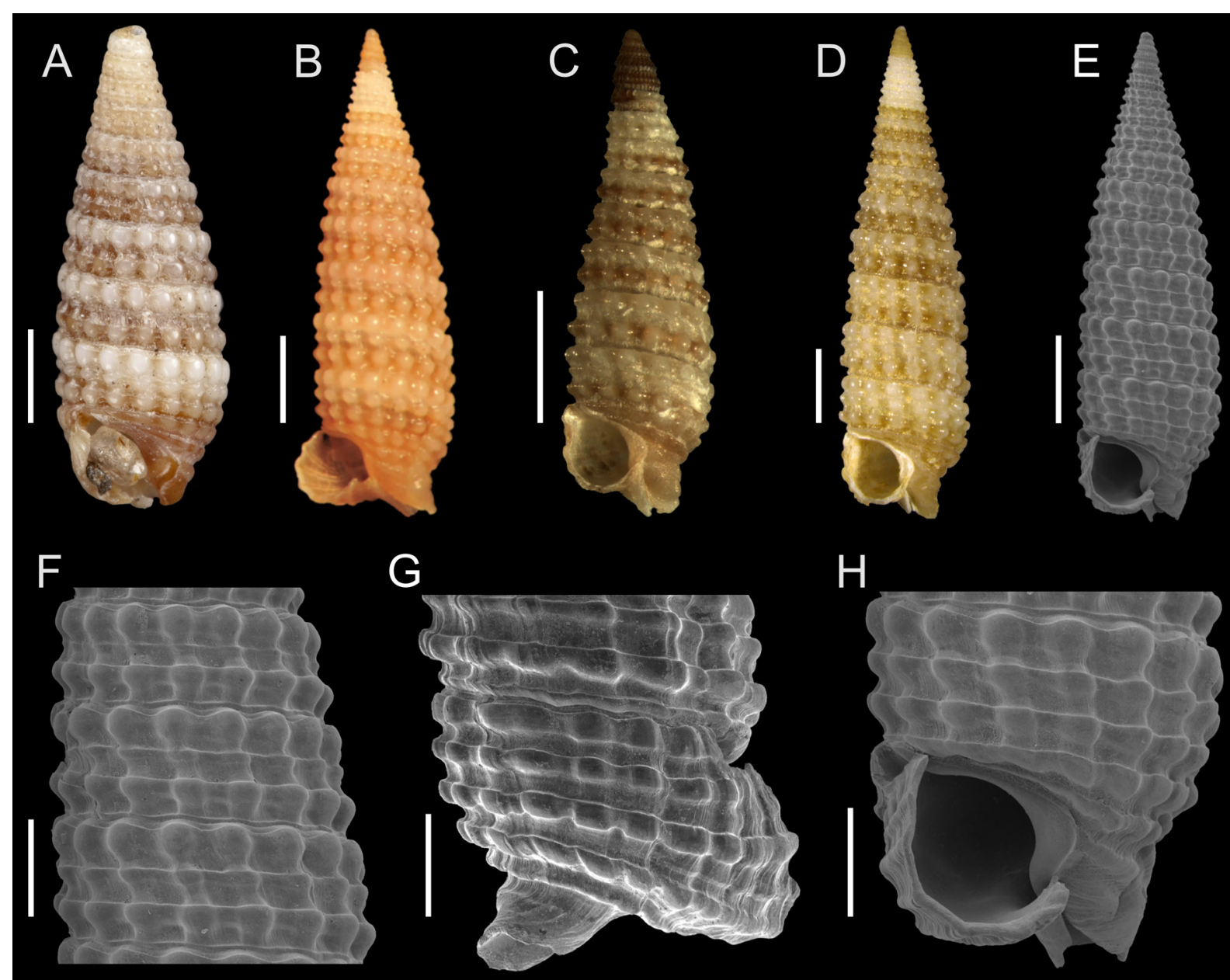

G
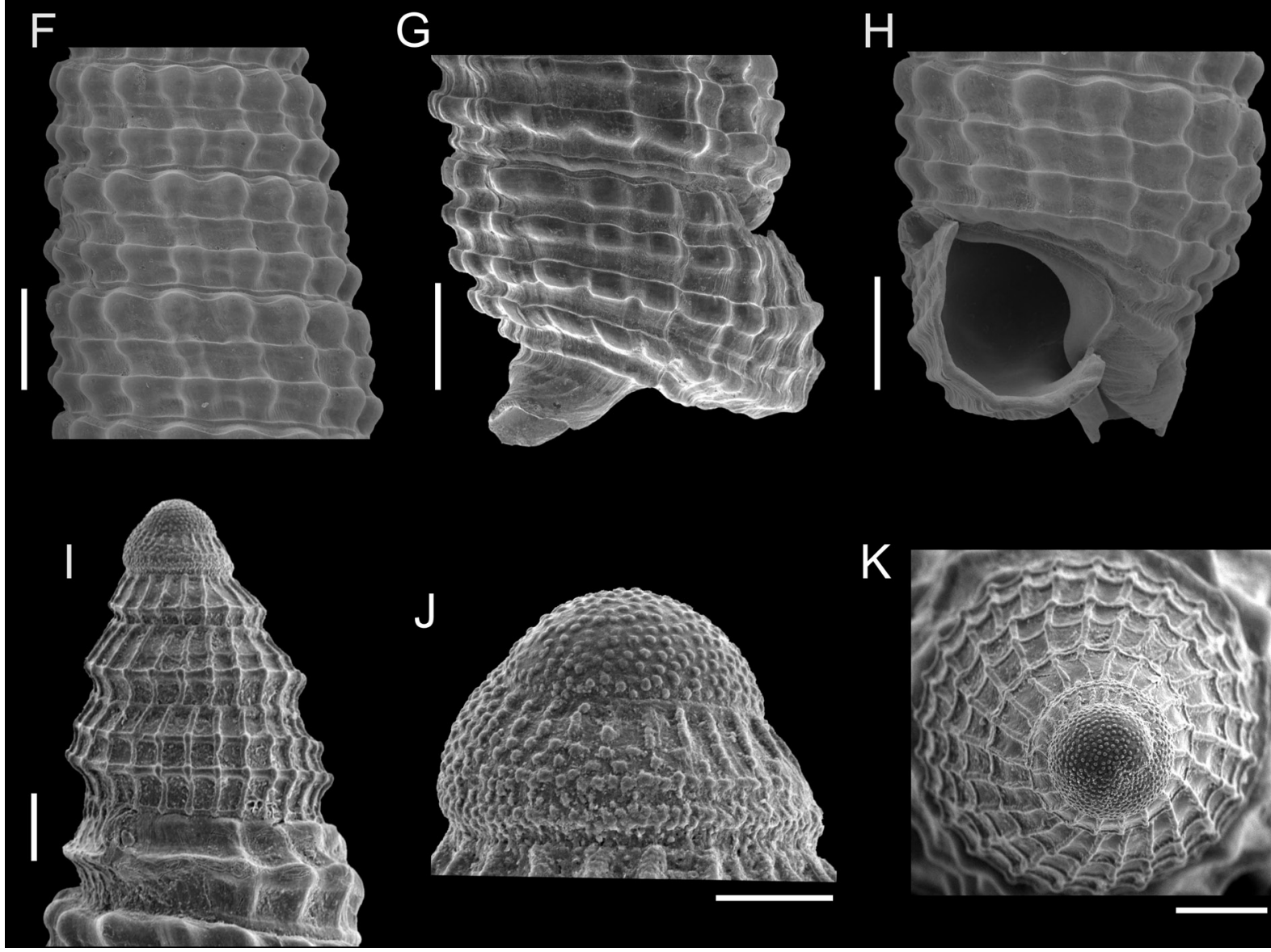

$\mathrm{H}$

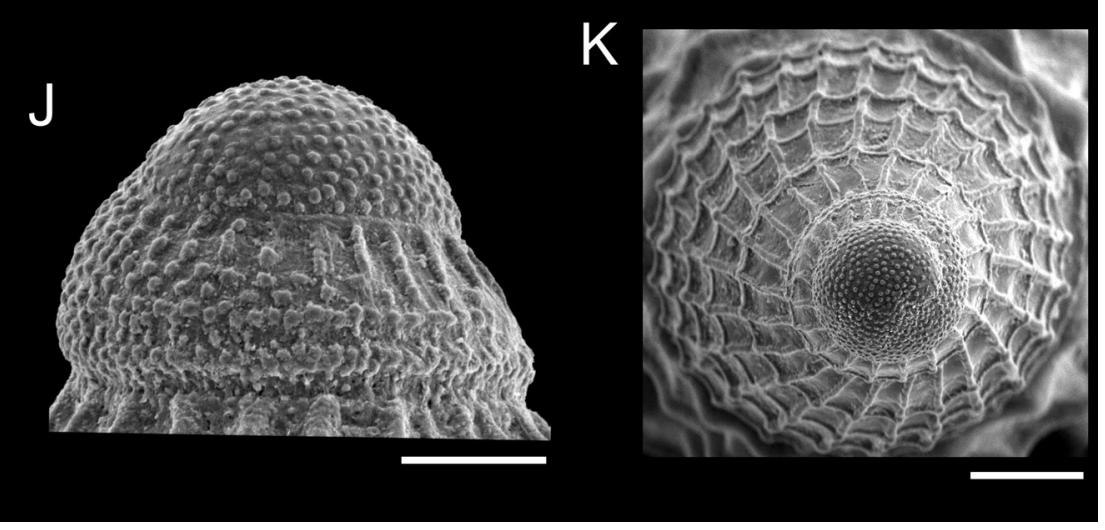

Fig. 95. Triphora atlantica Smith, 1890. A. Lectotype, NHM 1889.10.1.1374. B. MNRJ 18693*, $5.63 \mathrm{~mm}$. C. MNRJ 18972*, $3.71 \mathrm{~mm}$. D. MNRJ 31984*, $6.65 \mathrm{~mm}$. E-F, H. Same shell as B. G. Same shell as D. I-K. Same shell as C. Scale bars: A-E $=1 \mathrm{~mm} ; \mathrm{F}-\mathrm{H}=500 \mu \mathrm{m} ; \mathrm{I}, \mathrm{K}=100 \mu \mathrm{m} ; \mathrm{J}=50 \mu \mathrm{m}$. Photo credits A: Andreia Salvador (NHM). 


\section{Material examined}

BRAZIL - Amapá • 1 spec.; 035ㅇ'43" N, 49³3'24" W; 2001; MNRJ 32573*. - Maranhão • 1 spec.;

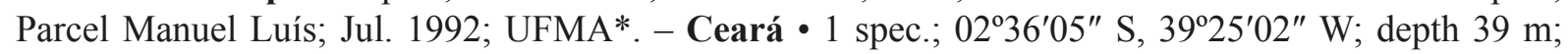

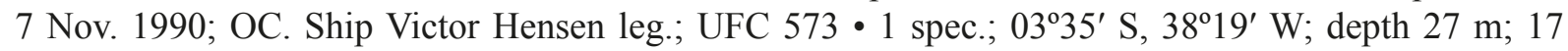
Apr. 1968; OC. Ship Almirante Saldanha leg.; MORG 52619. - Rio Grande do Norte 4 specs; BPot 1-MR32; MNRJ 31480* - 2 specs; BPot 1-MR41; MNRJ 31481* • 1 spec.; BPot 1-MR42; MNRJ 31482* • 4 specs; BPot 1-MR45; MNRJ 31483* • 4 specs; BPot 2-MR32; MNRJ 31484*• 1 spec.; BPot 2-MR33; MNRJ 31485* • 1 spec.; BPot 2-MR34; MNRJ 31486* • 1 spec.; BPot 2-MR42; MNRJ 31487* • 1 spec.; BPot 2-MR44; MNRJ 31488* • 9 specs; BPot 2-MR45; MNRJ 31489*. Fernando de Noronha Archipelago • 2 specs; Baía Sueste; depth 17 m; Jan. 1979; MORG 52621*. - Bahia • 1 spec.; Salvador, Itapuã; MZSP 133315 - 1 spec.; 13²9'44" S, 38 48'19" W; depth 33 m; 25 Nov. 2010; MNRJ 33083* • 1 spec.; Ilhéus; MNRJ 32376* • 1 spec.; REVIZEE-Central C5-7R; MNRJ 18630* • 1 spec.; REVIZEE-Central C5-7R; IBUFRJ 19500 • 2 specs; REVIZEE-Central C513R; IBUFRJ 13320 • 3 specs; JOPS st. 3237; MNRJ 33812* • 3 specs; JOPS st. 3239; MNRJ 33804*. Espírito Santo • 1 spec.; REVIZEE-Central C1-VV33; MORG 52596 • 3 specs; REVIZEE-Central C1C65; IBUFRJ 9487 • 1 spec.; REVIZEE-Central C1-C65; IBUFRJ $19496 \bullet 1$ spec.; REVIZEE-Central C1-C65; IBUFRJ 19525 • 2 specs; REVIZEE-Central C1-C65; MORG 52598 • 3 specs; REVIZEECentral C1-C64; IBUFRJ 19491 • 14 specs; REVIZEE-Central C1-VV38; IBUFRJ 19607 • 1 spec.; REVIZEE-Central C1-VV38; MORG 40338 - 1 spec.; 19²2'46" S, 39³9'26" W; 12 m; Oct. 2003; MNRJ 31165* • 1 spec.; 19²2'46" S, 39 39'26" W; depth 12 m; Oct. 2003; MNRJ 31984* • 1 spec.; $19^{\circ} 25^{\prime} 08^{\prime \prime} \mathrm{S}, 39^{\circ} 15^{\prime} 59^{\prime \prime} \mathrm{W}$; depth 65 m; Oct. 2003; MNRJ 30770* • 1 spec.; 19²6'03" S, 39²2'35" W; depth 44 m; Oct. 2003; MNRJ 30746* • 1 spec.; 1940'26" S, 39³6'19" W; depth 40 m; 2 Dec. 2011; MNRJ 34824* • 2 specs; 1940'26" S, 39³6'19" W; depth 40 m; 2 Dec. 2011; MNRJ 34980* • 1 spec.; REVIZEE-Central C1-VV24; IBUFRJ 19470 • $1 \mathrm{spec}$.; REVIZEE-Central C1-VV24; MORG 52255 • 4 specs; $20^{\circ} 14^{\prime}$ S, $40^{\circ} 12^{\prime}$ W; Jun. 2008; MNRJ 32648* 4 specs; $20^{\circ} 18^{\prime}$ S, $40^{\circ} 14^{\prime}$ W; Mar. 1993; V. Abud leg.; MORG 40024 • 1 spec.; Guarapari; 25-30 m; Mar. 1994; A. Bodart leg.; CHL • 1 spec.; Guarapari; depth 15-20 m; May 1994; A. Bodart leg.; CHL • 1 spec.; off Guarapari; 1998; MZSP 29033 • 2 specs; Porto de Ubú; $20^{\circ} 47^{\prime}$ S, $40^{\circ} 32^{\prime} \mathrm{W}$; Sep. 2007; MNRJ 30835* • 1 spec.; Porto de Ubú; $20^{\circ} 47^{\prime} \mathrm{S}, 40^{\circ} 32^{\prime} \mathrm{W}$; Sep. 2007; MNRJ 30901* • 1 spec.; Porto de Ubú; $20^{\circ} 47^{\prime}$ S, 40³2' W; Oct. 2008; MNRJ 31023* - 3 specs; Porto de Ubú; 2047' S, 40³2' W; Mar. 2010; MNRJ 31036* - 2 specs; Porto de Ubú; $20^{\circ} 47^{\prime}$ S, 40³2' W; Mar. 2010; MNRJ 31038* 1 spec.; Porto de Ubú; 2047' S, 40³2' W; Mar. 2010; MNRJ 31042* • 3 specs; Porto de Ubú; 2047' S, 40³2' W; Mar. 2010; MNRJ 31050* • 2 specs; Porto

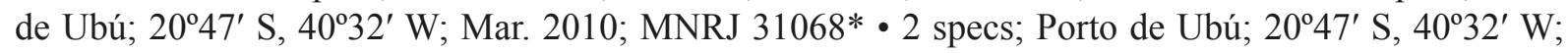
Mar. 2010; MNRJ 31075* • 1 spec.; Porto de Ubú; 2047' S, 40³2' W; Mar. 2010; MNRJ 31078* • 3 specs; Porto de Ubú; 2047' S, 40³2' W; Mar. 2010; MNRJ 31086*• 1 spec.; Porto de Ubú; $20^{\circ} 47^{\prime}$ S, 40³2' W; Nov. 2011; MNRJ 31127* • 32 specs; Piúma; 1993; IBUFRJ 8593. - Vitória-Trindade Chain - 1 spec.; Trindade Island; 2029'40" S, 2920'33" W; 15 Jun. 2012; MZSP 109814. - Campos Basin (Espírito Santo/Rio de Janeiro) 2 specs; • 2047' S, 40²6’ W; 29 Aug. 1979; OC. Ship Almirante Câmara leg.; IBUFRJ 19522 • 2 specs; 20 $0^{\circ} 53^{\prime}$ S, 40¹2' W; 26 Aug. 1979; OC. Ship Almirante Câmara leg.; IBUFRJ 19516 • 1 spec.; 2122' S, 4050' W; 27 Aug. 1979; OC. Ship Almirante Câmara leg.; IBUFRJ 7671 • 1 spec.; REVIZEE-Central C2-36R; IBUFRJ 10689 • 4 specs; REVIZEE-Central C1VV22; IBUFRJ 11387 • 1 spec.; REVIZEE-Central C1-VV22; IBUFRJ 19508 • 2 specs; REVIZEECentral C1-VV16; IBUFRJ 19488 - 7 specs; REVIZEE-Central C1-VV21; IBUFRJ 19538 - 2 specs; REVIZEE-Central C1-VV21; MORG $41237 \cdot 2$ specs; 2042' S, 4006' W; 27 Aug. 1979; OC. Ship Almirante Câmara leg.; IBUFRJ 19552 • 11 specs; REVIZEE-Central C1-D3; IBUFRJ 19586 • 2 specs; HAB 13-I2; MNRJ 17958* • 1 spec.; HAB 13-H4; MNRJ 17960*• 2 specs; HAB 13-H2; MNRJ 17968* - 1 spec.; HAB 11-C4; MNRJ 17986* • 1 spec.; HAB 17-I3; MNRJ 18392* • 8 specs; HAB 17-I2; MNRJ 18408* • 5 specs; HAB 16-H2; MNRJ 18432* • 1 spec.; HAB 16-G3; MNRJ 18634* 1 spec.; HAB 17-I1; MNRJ 18635* 2 specs; HAB 13-H1; MNRJ 18693* 3 specs; 2304' S, 40 $59^{\prime}$ W; 17 Dec. 2004; MNRJ 18972* • 1 spec.; 2051' S, 40²8' W; 29 Oct. 2008; MZSP 89604. - Rio de 
Janeiro • 1 spec.; Búzios, Praia da Ferradura; MNRJ 18601* • 1 spec.; Arraial do Cabo; 25-30 m; Mar. 2003; P. Gonçalves leg.; MZSP 73132 • 1 spec.; Arraial do Cabo; depth 25-30 m; Mar. 2003; P. Gonçalves leg.; MZSP 133324 • 1 spec.; Arraial do Cabo; depth 25-30 m; Mar. 2003; P. Gonçalves leg.; CHL.

SAINT HELENA ISLAND • 6 specs, all shells with broken apex; USNM 124068.

Triphora ellyae De Jong \& Coomans, 1988

Fig. 96

Triphora ellyae De Jong \& Coomans, 1988: 50, pl. 34 fig. 242.

Triphora orteai Espinosa, 2001: 21, fig. 7.

Triphora ellyae - Rolán \& Fernández-Garcés 1995: 13, figs 23-25; 2007: pl. 5 figs 17-21. — Espinosa et al. 2007: 74; 2012: 258. — Lee 2009: 92. — Fernandes et al. 2013: 15, figs 16, $27,37$.

Triphora cf. ellyae - Reyes et al. 2007: 383.

\section{Material examined}

BRAZIL - Rio Grande do Norte • 1 spec.; BPot 1-MR32; MNRJ 31495 • 1 spec.; BPot 1-MR41; MNRJ 31496*. - Bahia • 1 spec.; Salvador, Itapuã; MORG 33723 • 2 specs; 132ㅇ'17" S, 38 48'43" W; 35 m; 24 Nov. 2007; MNRJ 32609* • 3 specs; Ilhéus; MNRJ 32372*. - Espírito Santo • 1 spec.; REVIZEE-Central C1-C65; IBUFRJ 19526 • 5 specs; REVIZEE-Central C1-VV38; IBUFRJ $19612 \bullet$ 1 spec.; REVIZEE-Central C1-VV38; MORG 52251 - 1 spec.; $19^{\circ} 26^{\prime} 16^{\prime \prime} \mathrm{S}, 39^{\circ} 15^{\prime 2} 22^{\prime \prime} \mathrm{W}$; depth $52 \mathrm{~m}$; Oct. 2003; MNRJ 32999* • 1 spec.; 20¹4' S, 40¹2' W; Jun. 2008; MNRJ 32654* • 1 spec.; Porto de Ubú; 2047' S, 40³2' W; Sep. 2007; MNRJ 30834* • 7 specs; Piúma; 1993; IBUFRJ 19699. - Campos Basin (Espírito Santo/Rio de Janeiro) • 2 specs; REVIZEE-Central C1-D3; IBUFRJ 19590 • 9 specs; $22^{\circ} 42^{\prime} \mathrm{S}, 40^{\circ} 40^{\prime} \mathrm{W}$; depth 5-10 m; Mar. 2007; MNRJ 15400* • 1 spec.; HAB 11-D3; MNRJ 17953* - 1 spec.; HAB 11-G3; MNRJ 17959* • 1 spec.; HAB 16-B4; MNRJ 18374* 1 spec.; HAB 16-G3; MNRJ 18626* • 1 spec.; HAB 16-G3; MNRJ 18636* • 2 specs; HAB 16-H3; MNRJ 18632* • 5 specs; $22^{\circ} 42^{\prime} \mathrm{S}, 40^{\circ} 40^{\prime} \mathrm{W}$; depth $110 \mathrm{~m}$; 2006; MNRJ 18753* - 2 specs; $22^{\circ} 42^{\prime} \mathrm{S}, 40^{\circ} 40^{\prime} \mathrm{W}$; depth 5-10 m; MNRJ 18955* • 1 spec.; $22^{\circ} 42^{\prime}$ S, 4040' W; depth 12 m; 22 Mar. 2004; MNRJ 30856* 1 spec.; $22^{\circ} 48^{\prime}$ S, 4045' W; depth 110 m; 27 Jan. 1998; OC. Ship Astro Garoupa leg.; IBUFRJ $11699 \bullet 1$ spec.; $23^{\circ} 04^{\prime} \mathrm{S}, 40^{\circ} 59^{\prime} \mathrm{W}$; 1 Apr. 2005; MNRJ 31112* 5 specs; $22^{\circ} 42^{\prime} \mathrm{S}, 40^{\circ} 40^{\prime} \mathrm{W}$; depth 12 m; Oct. 2005;

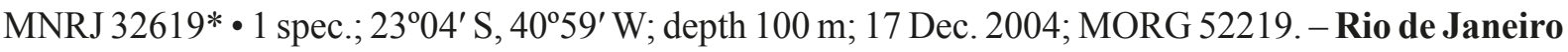
- 1 spec.; Ilha da Gipóia, Angra dos Reis; RAP-BIG st. 22; UERJ 8686 • 2 specs; Ilha Grande, Ponta da Enseada; RAP-BIG st. 31; UERJ 5181 • 7 specs; Ilha Grande; RAP-BIG st. 40; UERJ 4343 - 2 specs; Ilha Grande, Praia dos Morcegos; RAP-BIG st. 32; UERJ 5583 - 1 spec.; Ilha Grande, Ponta Acaiá; RAP-BIG st. 38; UERJ 3840 • 1 spec.; Ilha Grande, Dois Rios; 20 Nov. 1996; UERJ $7470 \bullet 2$ specs; Ilha Grande, Ponta do Aventureiro; RAP-BIG st. 37; UERJ 4795 • 1 spec.; Ilha de Búzios, Angra dos Reis; RAP-BIG st. 23; UERJ 7889 • 1 spec.; Ilha do Araújo, Paraty; RAP-BIG st. 13; UERJ 4632 • 1 spec.; Ilha do Araújo, Paraty; RAP-BIG st. 13; UERJ 7584 • 3 specs; Paraty, Praia Vermelha; RAP-BIG st. 10; UERJ 3792 • 2 specs; Paraty, Ponta de Juatinga; RAP-BIG st. 1; UERJ $3761 \bullet 1$ spec.; Paraty, Ponta de Juatinga; RAP-BIG st. 1; UERJ 8685. - São Paulo • 1 spec.; Ubatuba, Praia da Enseada; 21 May 1950; L. Morretes leg.; MZSP 52022 • 1 spec.; São Sebastião, Barra do Una; Nov. 2003; MNRJ 34546*. Paraná 1 spec.; Ilha dos Ratos; O. de Fiore leg.; this is an old lot and its origin is uncertain whether indeed "Ilha dos Ratos" ( $25^{\circ} 29^{\prime}$ S, 48 $42^{\prime}$ W, municipality of Antonina, a current low-salinity site) or "Ilha do Rato" ( $25^{\circ} 51^{\prime}$ S, $48^{\circ} 34^{\prime}$ W, municipality of Guaratuba, a near-marine site), both in Paraná state; 
MZSP 52021. - Santa Catarina • 2 specs; Bombinhas, Praia da Conceição; 27ำ1 $04^{\prime \prime}$ S, 48 $29^{\prime} 11^{\prime \prime}$ W ; depth 0-5 m; 19 Dec. 2019; M.R. Fernandes leg.; MNRJ 23259 • 1 spec.; Bombinhas, Praia da Tainha; 27¹3'02" S, 48³0'29" W ; depth 0-5 m; 20 Dec. 2019; M.R. Fernandes leg.; MNRJ 23346.
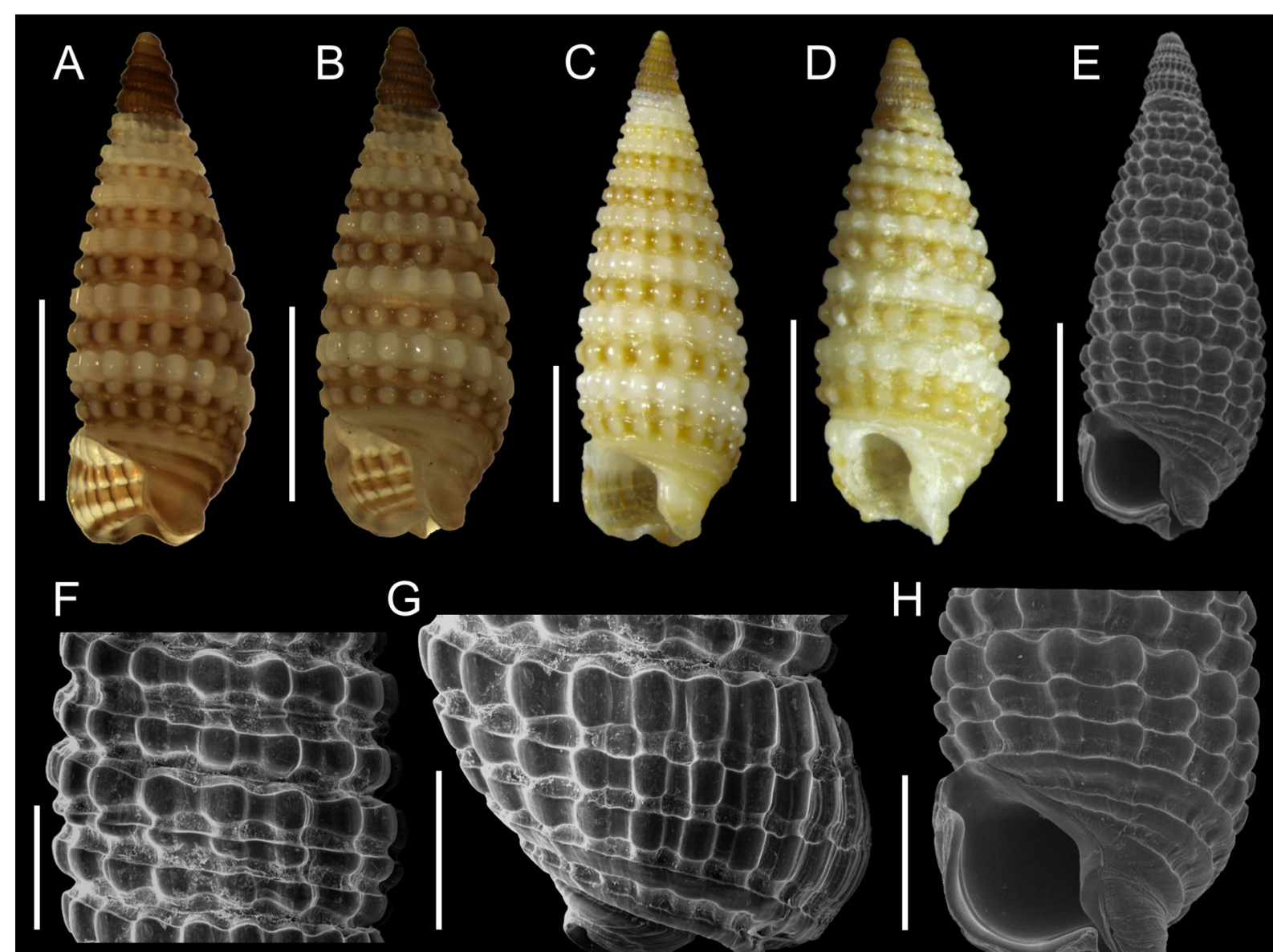

G

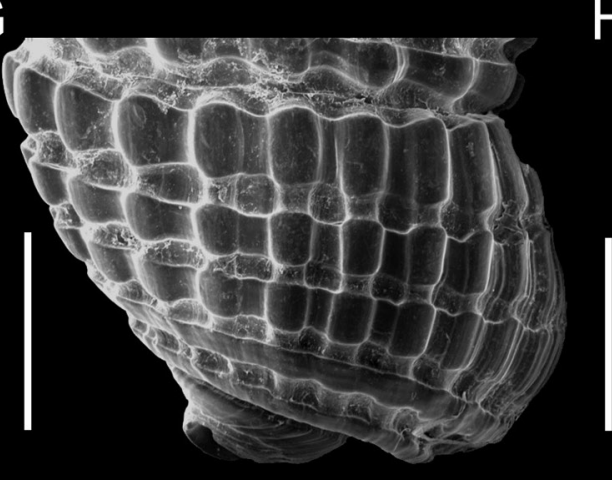

$\mathrm{H}$
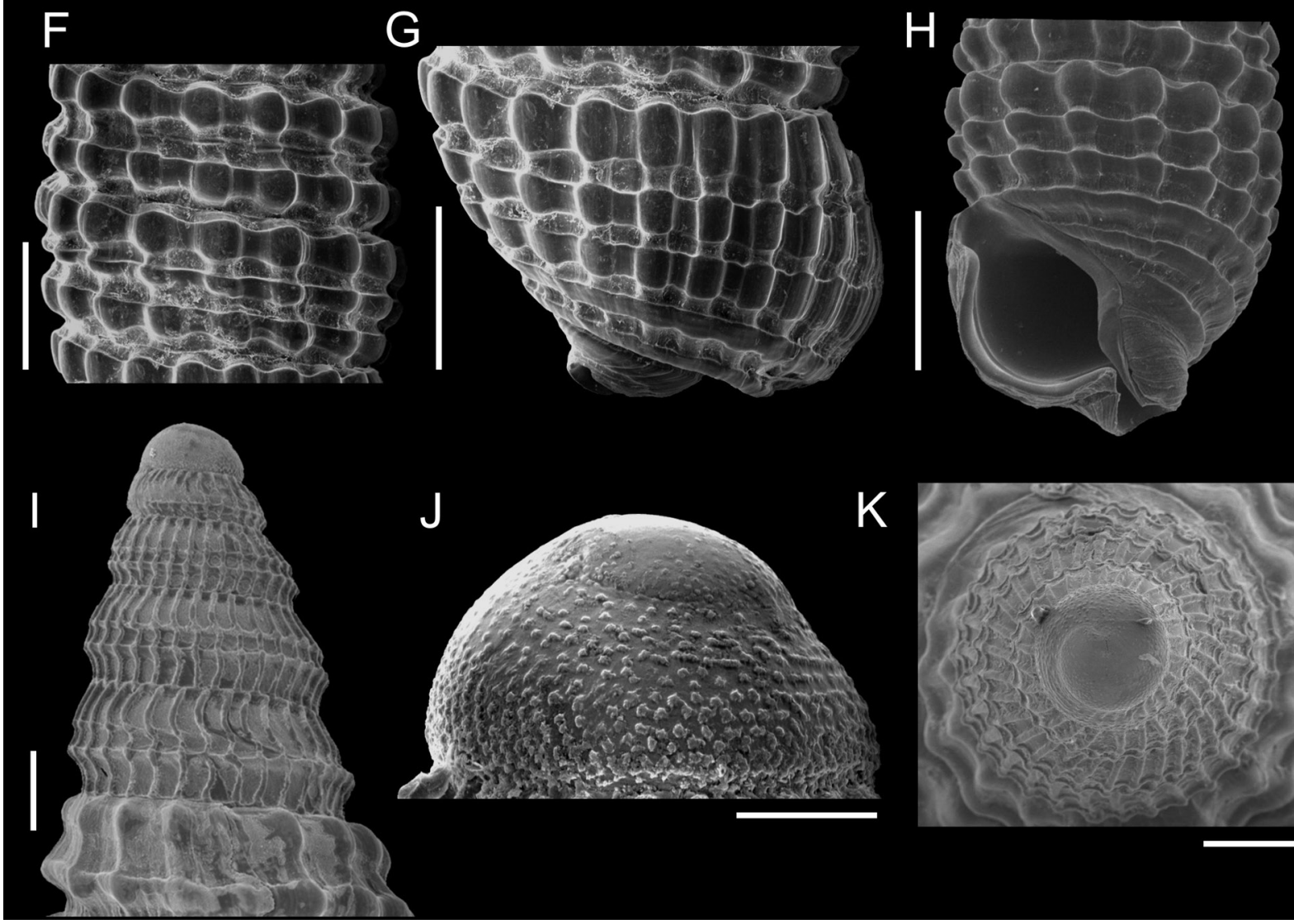

K

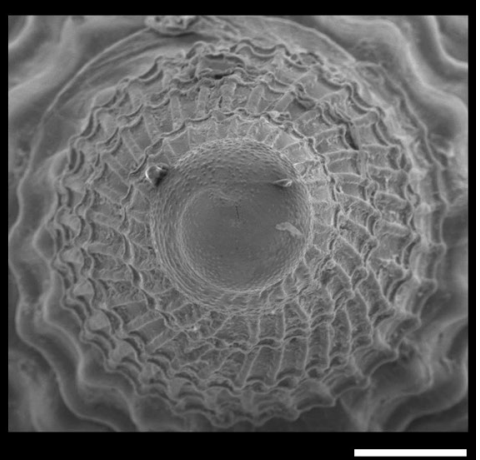

Fig. 96. Triphora ellyae De Jong \& Coomans, 1988. A-B. MNRJ 15400*, $2.56 \mathrm{~mm}$ and $2.64 \mathrm{~mm}$, respectively. C. MNRJ 32619*, $3.80 \mathrm{~mm}$. D. UERJ 3840, $2.80 \mathrm{~mm}$. E. MNRJ 18955*, $2.86 \mathrm{~mm}$. F-H, J-K. Same shell as E. I. MNRJ 18626*. Scale bars: A-E $=1 \mathrm{~mm} ; \mathrm{F}-\mathrm{H}=500 \mu \mathrm{m} ; \mathrm{I}, \mathrm{K}=100 \mu \mathrm{m}$; J = $50 \mu \mathrm{m}$. 


\section{Remarks}

Shells of T. ellyae usually show the median spiral cord of the teleoconch emerging in the fifth/sixth whorl, rarely at the seventh whorl (Fernandes et al. 2013; Fernandes 2014). A few shells sampled from Baía da Ilha Grande (Rio de Janeiro State) and São Paulo State had the median cord emerging as early as the fourth whorl (Fig. 96D).

Triphora elvirae De Jong \& Coomans, 1988

Fig. 97

Triphora elvirae De Jong \& Coomans, 1988: 50, pl. 34 fig. 240.

Triphora elvirae - Rolán \& Fernández-Garcés 1995: 13, figs 20-22; 2007: pl. 5 fig. 22-23. — Garcia \&

Lee 2011. — Fernandes et al. 2013: 16, figs 17, 28, 38. — Redfern 2013: 126, fig. 357.

Cosmotriphora elvirae - Redfern 2001: 65, pl. 32 fig. 273.

\section{Material examined}

BAHAMAS • 2 specs; Gorda Cay; 2005; B. Dietz leg.; MZSP 79472.

BRAZIL - Maranhão • 1 spec.; 0130'33" S, 4320'28" W; depth 59 m; 22 Nov. 2008; OC. Ship Amorim do Valle leg.; MZSP 94408. - Rio Grande do Norte • 1 spec.; BPot 1-MR32; MNRJ 31490* • 1 spec.; BPot 1-MR41; MNRJ 31491* • 4 specs; BPot 1-MR42; MNRJ 31492* • 1 spec.; BPot 1-MR45; MNRJ 31493* • 1 spec.; BPot 2-MR44; MNRJ 31494*. - Atol das Rocas • 1 spec.; Feb. 1977; in broken coral; MORG 52623*. - Bahia • 1 spec.; Salvador, Itapuã; MORG 13823 • 2 specs; Salvador, Itapuã; MORG 33757 • 1 spec.; Salvador; MZSP $133336 \bullet 2$ specs; Ilhéus; MNRJ 32379* • 1 spec.; REVIZEECentral C5-13R; IBUFRJ 19575 • 2 specs; JOPS st. 3237; MNRJ 33813*. - Espírito Santo • 2 specs; REVIZEE-Central C1-C64; IBUFRJ 19492 • 3 specs; REVIZEE-Central C1-VV38; IBUFRJ $12886 \bullet$ 2 specs; REVIZEE-Central C1-VV38; IBUFRJ 19617 • 1 spec.; 19²5'05" S, 39¹5'54" W; depth 65 m; Oct. 2003; MNRJ 32595* • 1 spec.; 1926'00" S, 39²2'30" W; depth 55 m; Oct. 2003; MNRJ 32176* • 1 spec.; 19²6'03" S, 39²2'35" W; depth 44 m; Oct. 2003; MNRJ 30951* • 1 spec.; REVIZEE-Central C1-VV24; IBUFRJ 19451 • 2 specs; 20¹4' S, 40¹2' W; Jun. 2008; MNRJ 32649* • 3 specs; $20^{\circ} 47^{\prime}$ S,

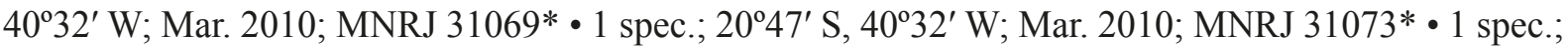
$20^{\circ} 47^{\prime}$ S, 40³2' W; Mar. 2010; MNRJ 31088* • 1 spec.; 2047' S, 40³2' W; Mar. 2010; MNRJ 31054*• 1 spec.; 2047' S, 40³2' W; Mar. 2010; MNRJ 31061* • 6 specs; Piúma; 1993; IBUFRJ 8640. - Campos

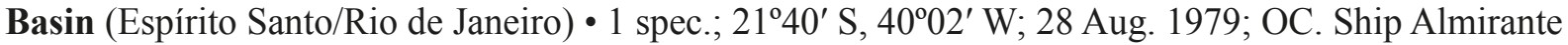
Câmara leg.; IBUFRJ 7681 • 1 spec.; HAB 13-I2; MNRJ 17957* • 2 specs; HAB 17-I2; MNRJ 18616* • 1 spec.; HAB 17-I2; MNRJ 18617* • 2 specs; HAB 17-I2; MNRJ 18619*• 2 specs; 230' $\mathrm{S}, 40^{\circ} 58^{\prime} \mathrm{W}$; depth 100 m; 17 Sep. 2004; MNRJ 31138* • 1 spec.; 2304' S, 4059' W; depth 100 m; 17 Dec. 2004; MORG 52218. - Rio de Janeiro • 1 spec.; Ilha de Macacos, Angra dos Reis; RAP-BIG st. 30; UERJ 5542.

UNITED STATES OF AMERICA - Florida • 2 specs; off Boynton Beach; depth 27-36 m; Apr. 1970; BMSM 129122.

Triphora portoricensis Rolán \& Redfern, 2008

“Triphora” portoricensis Rolán \& Redfern in Rolán \& Fernández-Garcés 2008: 158, fig. 32a-e.

“Triphora" portoricensis - Redfern 2013: 127, fig. 358a-b. - Fernandes \& Pimenta 2015: 505, fig. 6. 
Iniforis sp. - Redfern 2001: 66, pl. 33 fig. 278a-b.

\section{Material examined}

BRAZIL - Sergipe • 1 worn spec.; Petro/UFS st. 18.1; UFS.
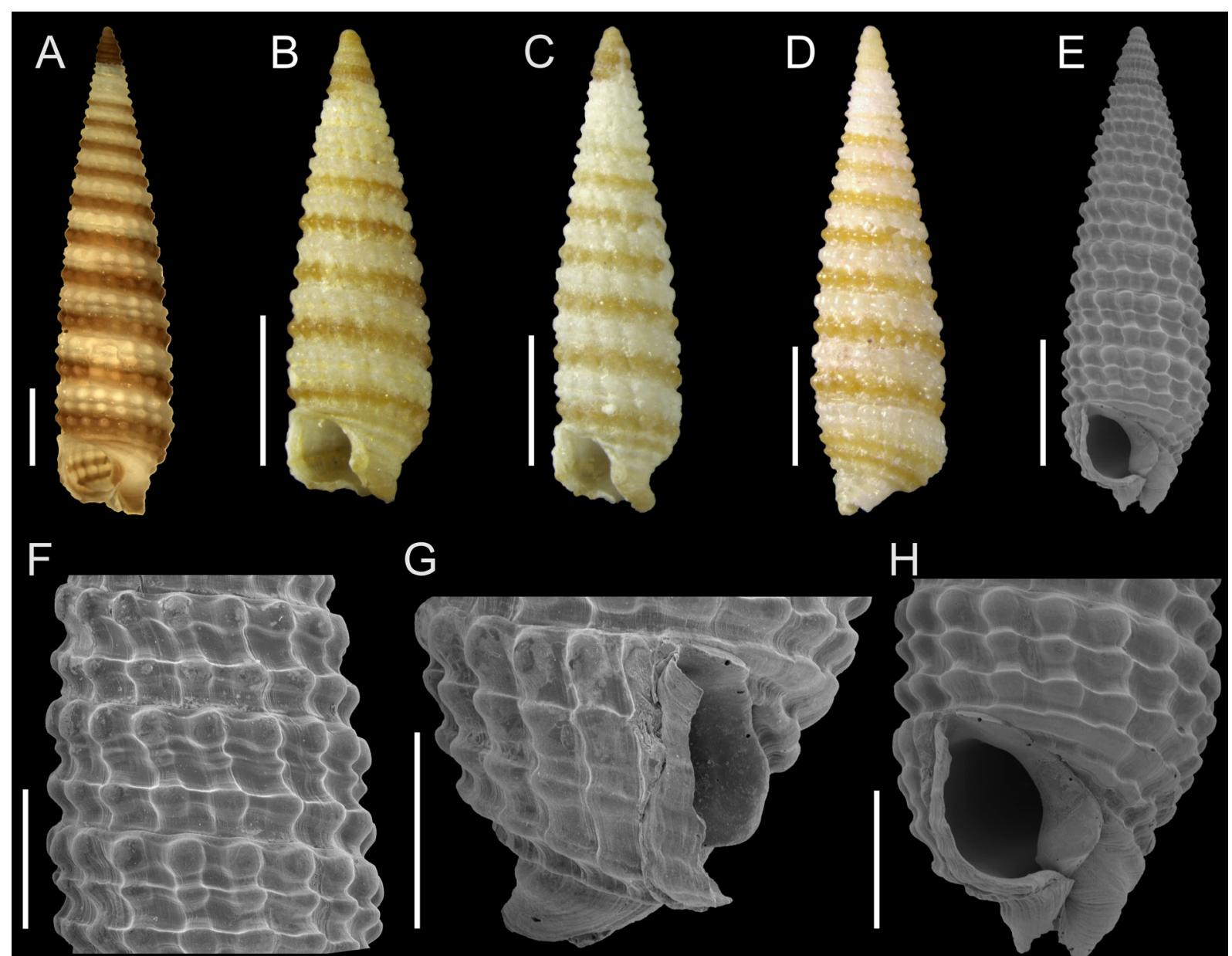

G
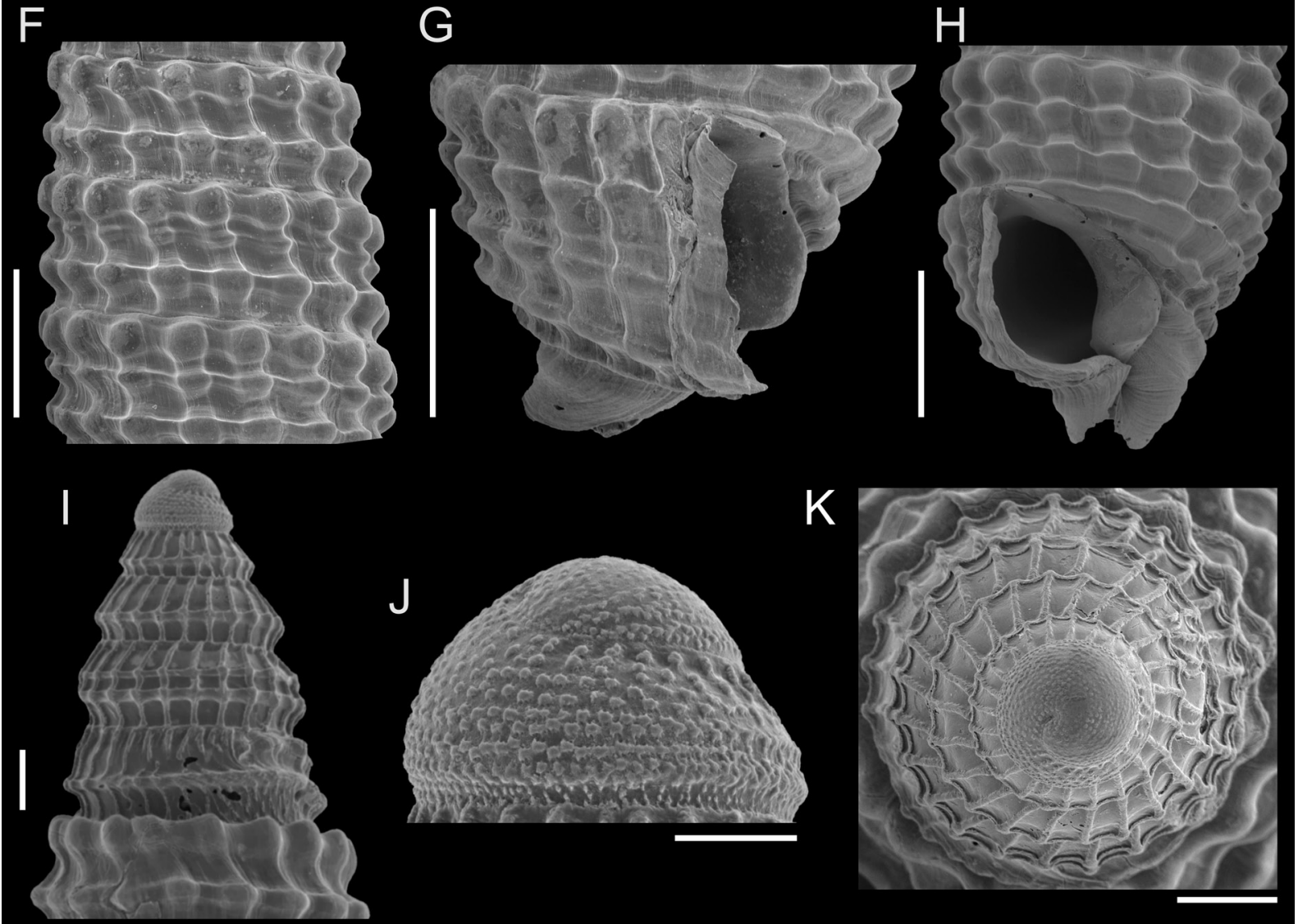

Fig. 97. Triphora elvirae De Jong \& Coomans, 1988. A. MNRJ 18619*, $6.32 \mathrm{~mm}$. B. MNRJ 31069*, $3.16 \mathrm{~mm}$. C. MNRJ 31493*, $3.73 \mathrm{~mm}$. D. MNRJ 33813*, $4.12 \mathrm{~mm}$. E. MNRJ 18617*, $3.87 \mathrm{~mm}$. F-G. MNRJ 18754*. H-K. Same shell as E. Scale bars: A-E = $1 \mathrm{~mm}$; F-H = $500 \mu \mathrm{m}$; I, K = $100 \mu \mathrm{m} ; \mathrm{J}=50 \mu \mathrm{m}$. 
Triphora scylla Fernandes \& Pimenta, 2015

Triphora scylla Fernandes \& Pimenta, 2015: 509, fig. 8.

\section{Material examined}

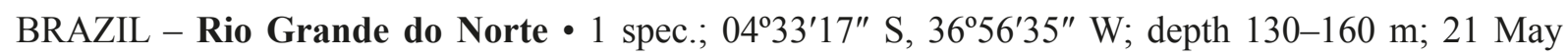
2011; MNRJ 35179*. - Sergipe - 2 specs; Petro/UFS st. E5-A1; with soft part preservation; UFS • 1 spec. ; Petro/UFS st. E6-A4; with soft part preservation; UFS - 7 specs; Petro/UFS st. 15.3; UFS • 1 spec.; Petro/UFS st. 18.1; UFS. - Espírito Santo • 1 spec.; 19²0'26" S, 39³6'19" W; depth 40 m; 2 Dec. 2011; OC. Ship Seward Johnson leg.; MNRJ 34827*. 